\title{
Geology and Geochemistry of the
}

Upper Miocene Phosphate Deposit

Near New Cuyama, Santa Barbara

County, California

\section{U.S. GEOLOGICAL SURVEY BULLETIN 1635}





\section{Geology and Geochemistry of the}

Upper Miocene Phosphate Deposit Near New Cuyama, Santa Barbara County, California

By ALBERT É. ROBERTS AND THOMAS L. VERCOUTERE 


\section{DEPARTMENT OF THE INTERIOR DONALD PAUL HODEL, Secretary

\author{
U.S. GEOLOGICAL SURVEY
} \\ Dallas L. Peck, Director}

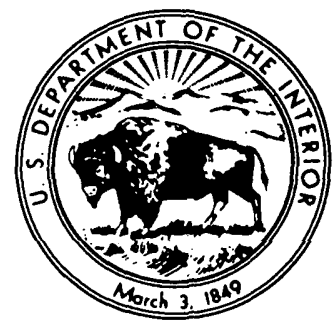

For sale by the

Books and Open-File Reports Section

U.S. Geological Survey

Federal Center, Box 25425

Denver, CO 80225

Library of Congress Cataloging-in-Publication Data

Roberts, Albert Eugene, 1921-

Geology and geochemistry of the Upper Miocene phosphate deposit near New Cuyama, Santa Barbara County, California.

(U.S. Geological Survey Bulletin 1635)

Bibliography: p. 23-27.

Supt. of Doc. No.: I 19.3:1635sa

1. Phosphate rock-California-New Cuyama.

2. Geology, stratigraphic-Miocene. 3. Geology-

California-New Cuyama. 4. Geochemistry-

California-

New Cuyama. I. Vercoutere, Thomas L. II. Title.

III. Series. 


\section{CONTENTS}

Glossary IV

Abstract 1

Introduction 1

Location and areal extent 2

Scope of investigation

Acknowledgments 2

Methods of study 3

Definition of terms 3

Geologic setting 3

Stratigraphic summary 5

Structural summary 6

Santa Margarita Formation 9

General features 9

Fauna and age 10

Lithologic composition 10

Lower phosphatic mudstone member $\quad 10$

Lower sandstone member 11

Upper phosphatic mudstone member 11

Upper sandstone member 11

Mineralogy and petrography of phosphatic components 11

Carbonate fluorapatite 11

Diagenetic alterations $\quad 12$

Opal-CT 13

Carbonates 13

Mica and smectite groups

Chemical composition $\quad 15$

Major constituents $\quad 15$

Minor constituents 15

Barium 16

Cadmium 16

Cerium 16

Manganese 17

Strontium 17

Thorium 17

Uranium 17

Zinc 19

Zirconium 19

Geochemical ratios 19

Phosphatic setting 19

Depositional environment 20

Phosphogenesis 20

Model for the Santa Margarita Formation 21

Phosphate resources of the upper phosphatic mudstone member of the Santa Margarita Formation

References cited 23

Stratigraphic sections and tables $7-12$

30

\section{PLATES}

In pocket

1. Geologic map of Cuyama Valley phosphate area, Santa Barbara County, California

2. Structure sections of Cuyama Valley phosphate area, Santa Barbara County, California

3. Isopach of the upper phosphatic mudstone member of the Santa Margarita Formation, Cuyama Valley phosphate area, Santa Barbara County, California

4. Columnar section and histogram of the major oxides of the trench 100 reference section, upper phosphatic mudstone member of the Santa Margarita Formation, Cuyama Valley phosphate area, Santa Barbara County, California

5. Correlation of trench data from the upper phosphatic mudstone member of the Santa Margarita Formation, Cuyama Valley phosphate area, Santa Barbara County, California

6. Photographs showing primary and secondary features of the phosphatic components in the upper phosphatic mudstone member of the Santa Margarita Formation, Cuyama Valley phosphate area, Santa Barbara County, California 


\section{FIGURES}

1. Map showing location of the phosphate study area in Cuyama Valley, Santa Barbara County, California 2

2. Generalized stratigraphic column of the phosphate area in Cuyama Valley, Santa Barbara County, California 4

3. Map showing relation of Salinian block to faults in California 7

4. Graph showing diagenetic variation of opal-CT $d(101)$ spacing related to depth of burial 14

5. Columnar section of the upper phosphatic mudstone member of the Santa Margarita Formation showing ore zones used in tonnage estimates 22

\section{TABLES}

1. X-ray characteristics, $d(101)$ spacing and $2 \theta$, of opal-CT from the upper phosphatic mudstone member of the Santa Margarita Formation, at trench 100 in Cuyama Valley phosphate area, Santa Barbara County, California 14

2. Rapid rock analyses of the upper phosphatic mudstone member of the Santa Margarita Formation, at trench 296 in Cuyama Valley phosphate area, Santa Barbara County, California 15

3. Average chemical composition of phosphorite pellets from trench 299 , stratigraphic unit 81 , upper phosphatic mudstone member of the Santa Margarita Formation, Cuyama Valley phosphate area, Santa Barbara County, California 15

4. Semiquantitative spectrographic analyses of major and minor elements of phosphorite pellets from trench 299, stratigraphic unit 81, of the upper phosphatic mudstone member of the Santa Margarita Formation, Cuyama Valley phosphate area, Santa Barbara County, California 16

5. Uranium and thorium analyses of the upper phosphatic mudstone member of the Santa Margarita Formation, at trench 100 in Cuyama Valley phosphate area, Santa Barbara County, California 18

6. Inferred phosphate resources in the upper phosphatic mudstone member of the Santa Margarita Formation, Cuyama Valley phosphate area, Santa Barbara County, California 23

7. Semiquantitative spectrographic analyses of the upper phosphatic mudstone member of the Santa Margarita Formation, at trench 100 in Cuyama Valley phosphate area, Santa Barbara County, California 76

8. Semiquantitative spectrographic analyses of the upper phosphatic mudstone member of the Santa Margarita Formation, at trench 294 in Cuyama Valley phosphate area, Santa Barbara County, California 82

9. Semiquantitative spectrographic analyses of the upper phosphatic mudstone member of the Santa Margarita Formation, at trench 295 in Cuyama Valley phosphate area, Santa Barbara County, California 83

10. Semiquantitative spectrographic analyses of the upper phosphatic mudstone member of the Santa Margarita Formation, at trench 296 in Cuyama Valley phosphate area, Santa Barbara County, California 84

11. Semiquantitative spectrographic analyses of the upper phosphatic mudstone member of the Santa Margarita Formation, at trench 297 in Cuyama Valley phosphate area, Santa Barbara County, California $\quad 88$

12. Semiquantitative spectrographic analyses of the upper phosphatic mudstone member of the Santa Margarita Formation, at trenches 299 and 300 in Cuyama Valley phosphate area, Santa Barbara County, California 89

\section{GLOSSARY}

Apatite.-A group of minerals composed of varying amounts of calcium phosphate, fluorine, chlorine, hydroxyl, or carbonate as well as several minor elements. When not specified, the term refers to carbonate fluorapatite.

Bentonite.-Generally considered to be a claystone composed essentially of smectite (montmorillonite) clay minerals. It is formed by post-depositional alteration of volcanic ash.

Claystone.-An indurated rock containing more than two-thirds clay-size grains.

Grainstone.-A mud-free carbonate rock.

Massive.-A textural term for a compact, internally structureless (usually bioturbated) rock that may be fine- to coarse-grained.

Muddy rock.-Rocks with greater than 20 percent clay-size particles but insufficient to be classified as a mudstone or claystone.

Mudstone.-Rocks with subequal amounts of clay-size particles, silt, and very fine sand-size grains.

Nodule.-A constructional particle' generally irregular in shape with contrasting composition from enclosing matrix and larger than $2 \mathrm{~mm}$. This size corresponds to the sand-gravel boundary.

Oolith.-A constructional particle 0.0625 to $2 \mathrm{~mm}$ in diameter having internal concentric structure. 
Opal-CT. - A form of silica derived from biogenic silica in which X-ray diffraction patterns indicate a poorly ordered or interlayered arrangement of cristobalite and tridymite lattices.

Pellet.-A constructional particle 0.0625 to $2 \mathrm{~mm}$ in diameter having no regular internal structure.

Phosphorite.-Rocks that contain more than 50 percent phosphatic framework.

Porcellanite.-A hard, dense, diagenetic alteration product of siliceous biogenic sediment caused by pressure owing to depth of burial. It is intermediate between diatomaceous mudstone and impure chert and less indurated, dense, and vitreous than chert.

Sandstone.- An indurated rock containing more than two-thirds sand-size grains.

Sandy.- Rocks with greater than 20 percent sand-size particles but insufficient to be classified a sandstone.

Shale.-A structural term for a fissile mudstone.

Siltstone.-An indurated rock containing more than two-thirds silt-size grains.

Silty. - Rocks with greater than 20 percent silt but insufficient to be classified a siltstone.

Wackestone.-A mud-supported carbonate sedimentary rock containing more than 10 percent grains.

Clastic rock terminology (Folk, 1957)

Rock

Components

Claystone

Mudstone

Siltstone

Sandstone

$>2 / 3$ clay-size fraction

Subequal amounts of clay-size particles, silt, and very fine sand-size grains

$>2 / 3$ silt-size fraction

$>2 / 3$ sand-size fraction

Composition of phosphate rocks
Rock

Phosphorite

Very phosphatic

Phosphatic

Moderately phosphatic

Slightly phosphatic
Phosphatic framework (\%)

$$
>50
$$

40-50

20-40

10-20

$1-10$
Grain sizes (Powers, 1953)

$$
\text { Particle }
$$

Granule

Very coarse grain

Coarse grain

Medium grain

Fine grain

Very fine grain
Size $(\mathrm{mm})$

$2.00-4.00$

$1.00-2.00$

$0.50-1.00$

$0.25-0.50$

$0.125-0.25$

$0.0625-0.125$
Phosphatic framework point counts (\%)

$\begin{array}{lc}\text { Very abundant } & >60 \\ \text { Abundant } & 40-60 \\ \text { Plentiful } & 20-40 \\ \text { Common } & 10-20 \\ \text { Rare } & 1-10 \\ \text { Very rare } & <1\end{array}$

Rock beds, thickness (Maher, 1959)

\begin{tabular}{lrl}
\hline & English & \multicolumn{1}{c}{ Metric } \\
\hline \multicolumn{3}{c}{ Beds } \\
\hline Thick & $2+\mathrm{ft}$ & $0.6+\mathrm{m}$ \\
Medium & 6 in. $-2 \mathrm{ft}$ & $150 \mathrm{~mm}-0.6 \mathrm{~m}$ \\
Thin & $2-6 \mathrm{in}$ & $50-150 \mathrm{~mm}$ \\
Very thin & $1 / 2-2 \mathrm{in}$ & $12-50 \mathrm{~mm}$ \\
& \multicolumn{3}{c}{ Laminae } \\
\hline Thick & $1 / 16-1 / 2$ in. & $1.5-12 \mathrm{~mm}$ \\
Thin & $<1 / 16$ in. & $<1.5 \mathrm{~mm}$ \\
\hline
\end{tabular}

$\begin{array}{lc} & \text { Sorting } \\ \text { Well-sorted grains } & 90 \text { percent concentrated in } 1 \text { or } 2 \text { size classes } \\ \text { Medium-sorted grains } & 90 \text { percent distributed in } 3 \text { or } 4 \text { size classes } \\ \text { Poorly sorted grains } & 90 \text { percent scattered in } 5 \text { or more size classes }\end{array}$

Conversions

\begin{tabular}{lcll}
\hline & English/ Metric & \multicolumn{2}{l}{ Metric/ English } \\
\hline $1 \mathrm{in.}$ & $2.54 \mathrm{~cm}$ & $1 \mathrm{~cm}$ & $0.394 \mathrm{in}$. \\
$1 \mathrm{ft}$ & $30.48 \mathrm{~cm}$ & $1 \mathrm{~m}$ & $39.37 \mathrm{in}$. \\
$1 \mathrm{mi}$ & $1.609 \mathrm{~km}$ & $1 \mathrm{~m}$ & $3.28 \mathrm{ft}$ \\
& & $1 \mathrm{~km}$ & $0.62 \mathrm{mi}$ \\
1 short ton & 0.907 metric ton & 1 metric ton & 1.102 short ton \\
\hline
\end{tabular}





\title{
Geology and Geochemistry of the Upper Miocene Phosphate Deposit Near New Cuyama, Santa Barbara County, California
}

\author{
By Albert E. Roberts and Thomas L. Vercoutere
}

\begin{abstract}
The Cuyama Valley phosphate deposit is situated along the southern edge of the Cuyama Valley in the foothills of the Sierra Madre Mountains, a part of the California Coast Ranges. The marine phosphate-bearing rocks in this area are part of the Santa Margarita Formation of provincial late Miocene age. The formation, which ranges from $1025 \mathrm{ft}(315 \mathrm{~m})$ to $1,500 \mathrm{ft}(640 \mathrm{~m})$ in thickness in the study area, is subdivided into two sandstone members and two phosphatic mudstone members.

The Santa Margarita Formation has been folded into northwest-trending anticlines and synclines by compression from the southwest. Throughout much of the area, formational attitudes are nearly vertical or overturned. The area is cut by northwest-trending faults that are parallel to the axes of the folds and by faults that cut obliquely across the folds and offset the phosphatic members to the northeast.
\end{abstract}

The phosphatic facies consists generally of brown to gray, laminated to medium-thick beds of massive to graded pelletic and nodular phosphorite, phosphatic mudstone, mudstone, siltstone, and some fine-grained sandstone. Physical characteristics of the components of the phosphatic facies suggest multiple stages of phosphatization. The pellets range from very fine to medium-sand size, and the nodules range from very coarse sand $(2 \mathrm{~mm})$ to medium-pebble size. Both. are generally structureless aggregates of submicrocrystalline carbonate fluorapatite containing terrigenous clay, silt, sand grains, and diatoms or shell fragments.

Faunal assemblages and sedimentary structures in the phosphatic facies are evidence that the phosphatic facies formed as an outer offshore mud shelf deposit. Phosphate probably was precipitated below the sediment water interface on the inner offshore shelf during prolonged calmwater conditions. Occasional changes in sea level, accompanied by changes in direction and energy of sea floor currents, winnowed away some of the finer grained material. This reworking process transformed slightly phosphatic mudstones into phosphatic siltstones or phosphorites.

Major rock forming oxides, trace elements, and uranium and thorium analyses of the upper phosphatic mudstone and select pelletal phosphorite beds are presented. The element concentrations of barium, cadmium, cerium, strontium, thorium, uranium, zinc, and zirconium are compared and contrasted with the element concentrations of worldwide occurrences of phosphorites and shales. Emphasis is on mode of incorporation of trace elements into the sediments.

A total of 138.58 million short tons ( 125.98 million metric tons) of greater than 8.0 percent $\mathrm{P}_{2} \mathrm{O}_{5}$ phosphate rock and 404.33 million short tons( 367.57 million metric tons) of greater than 5.0 percent $\mathrm{P}_{2} \mathrm{O}_{5}$ phosphatic rock are calculated for the upper phosphatic mudstone member of the Santa Margarita Formation in the Cuyama Valley phosphate area.

\section{INTRODUCTION}

California, a leading agricultural state, needs an everincreasing amount of phosphorus, an essential element for plant growth, to improve crop yields. Current requirements for phosphorus are met from imports or byproducts of other industries, such as phosphoric acid from Searles Lake brines.

Phosphate-bearing rocks are known' throughout much of California (Gower and Madsen, 1964; Dickert, 1966, 1971; Roberts, 1981); however, significant economic deposits have not been developed. The geologic provenance of California suggests that the Miocene marine sedimentary rocks occurring in the Coast Ranges between San Francisco and Los Angeles have the greatest potential for phosphatic deposits. Of these sedimentary rocks, the upper Miocene marine formations in the southern part of the Coast Ranges contain sufficient concentrations of phosphatic rock to warrant further study.

As part of the U.S. Geological Survey's program to evaluate the phosphate resources of the United States, a detailed stratigraphic and geochemical program was conducted during 1978 and 1979 on the strata of the upper phosphatic mudstone member of the Santa Margarita Formation in the Cuyama Valley, Santa Barbara County, Calif. The study area of the phosphate deposits is shown in figure l. Well data from the South Cuyama oil field and adjacent dry holes 
in the study area (pl. 1) were used to supply critical stratigraphic information not readily available in faulted or weathered exposures. The report includes stratigraphic descriptions of the upper phosphatic mudstone member of the Santa Margarita Formation and locations of the samples. A tabulation of chemical and X-ray analyses for selected samples is included (Stratigraphic Sections and Tables 7-12). A compilation of the study area's phosphate resources is included (table 6).

\section{Location and Areal Extent}

The Cuyama Valley phosphate deposit is $5 \mathrm{mi}(8 \mathrm{~km})$ south of the town of New Cuyama along the south edge of the Cuyama Valley in the foothills of the Sierra Madre Mountains in Santa Barbara County, Calif. (fig. 1). The deposit covers an area of about $15 \mathrm{sq} \mathrm{mi}\left(40 \mathrm{~km}^{2}\right)$; the area is about $1.5 \mathrm{mi}(2.5$ $\mathrm{km}$ ) wide and $10 \mathrm{mi}(16 \mathrm{~km})$ long and is oriented in a northwesterly direction.

\section{Scope of Investigation}

The U.S. Geological Survey investigation of the phosphate deposit in the southern Cuyama Valley was concerned mainly with the areal distribution, lithofacies relationships, time-stratigraphic relations, and chemical and mineralogical composition of the upper phosphatic mudstone member in the Santa Margarita Formation. The principal objective of the field investigations was to define areas in which phosphate-

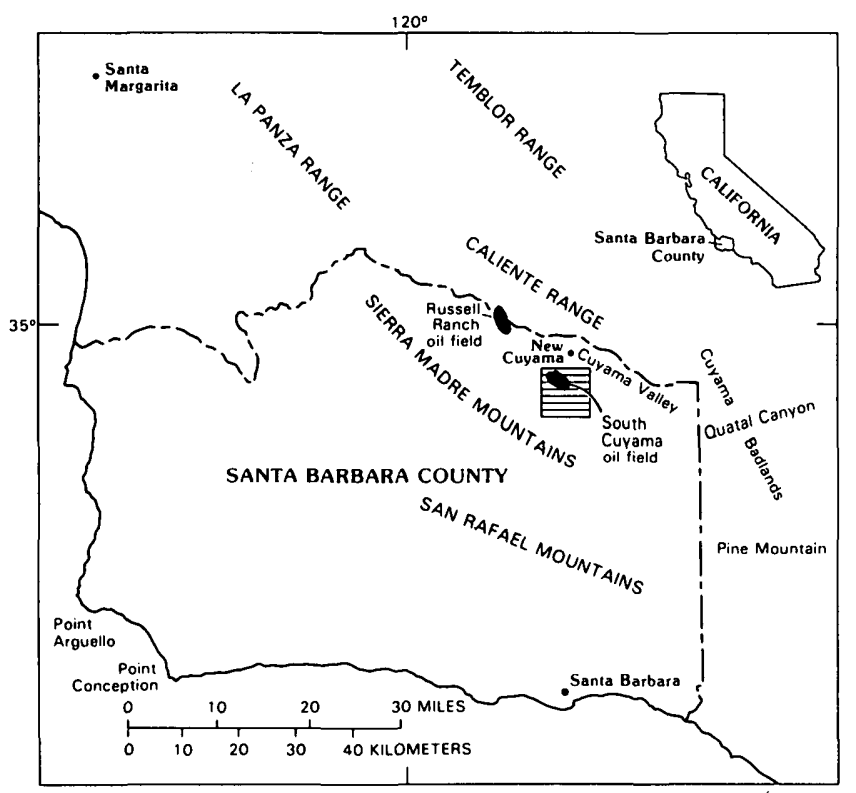

Figure 1. Location of phosphate study area (lined) in Cuyama Valley, Santa Barbara County, Calif. bearing rock is of the greatest economic potential. This entailed mainly the description, measurement, and sampling of stratigraphic sections. Fossil assemblages were collected to establish stratigraphic control. Laboratory investigations were made to identify the chemical and mineralogical composition of the phosphatic rocks, and to relate the physical, chemical, and biological environments to the formation and localization of the pelletal and nodular types of phosphatic rock in the marine sedimentary sequence. Such information is essential not only for understanding the origin and evaluating the resource potential of the phosphate deposit but also for providing critical data for future regional exploration.

The stratigraphy and structure have been summarized to help the reader relate the upper Miocene phosphatic rocks in the Salinas-Cuyama basin near New Cuyama, Calif., to other phosphatic deposits. A detailed analysis of the tectonic development and related sedimentation of the entire stratigraphic sequence near New Cuyama has not been done because it is beyond the scope of this report. For additional information the reader is referred to English (1916); Eaton (1939); Eaton and others (1941); Hill and Dibblee (1953); Hill and others (1958); Schwade and others (1958); Repenning and Vedder (1961); Cross (1962); Christensen (1965); Addicott (1968); Clifton (1968, 1981); Vedder (1968, 1973, 1975); Vedder and Brown (1968); Fritsche (1969, 1972); Page (1970, 1981); Huffman (1972); Ross (1972, 1974, 1978); Dibblee (1973a, b; 1976); Durham (1974); Johnson and Normark (1974); Vedder and Repenning (1975); Graham (1976, 1978); Howell and others (1977); Bartow (1978); Howell and Vedder (1978); and Lagoe (1984).

\section{Acknowledgments}

Many scientists cooperated and provided assistance in this investigation of the Cuyama Valley phosphate area. The authors are particularly grateful to $\mathrm{H}$. Edward Clifton, Howard D. Gower, Robert A. Gulbrandsen, Peter Oberlindacher, Robert L. Phillips, and John G. Vedder for their suggestions on stratigraphic correlations and (or) resource evaluations. Also, during the course of this study John G. Vedder provided additional unpublished data which aided in better understanding the relationships of the stratigraphic facies. Howard D. Gower generously provided sample material and measured sections from trenches in the study area and contributed to the correlation of phosphatic zones (pl. 5). The manuscript benefitted from the careful reviews of Robert A. Gulbrandsen, Peter Oberlindacher, and John G. Vedder. Preliminary illustrations were reviewed and final copy was prepared by Frances R. Mills. Field assistance and SEM photography were provided by Lawrence E. Mack. Field investigations were facilitated through the outstanding cooperation of Nicolas V. Bower and John H. Finney, operators of the Cuyama Phosphate Corporation. 


\section{Methods of Study}

Stratigraphic sections were measured by Brunton compass and tape traverses, described and sampled in trenches cut at intervals of $1,000-5,000 \mathrm{ft}(305-1,525 \mathrm{~m})$ or more normal to the strike of outcrop of the upper phosphatic mudstone member (pl. 1). Representative samples were collected usually from the middle of each lithologic unit, and channel samples were taken from every unit thicker than $2 \mathrm{ft}$ $(0.6 \mathrm{~m})$. Descriptions of these units include megascopic and microscopic determinations of physical properties and composition supported by X-ray diffractometry and a scanning electron microscope (SEM) equipped with an energy dispersive analysis of $\mathrm{X}$-rays (EDAX) system (see "Stratigraphic Sections"). Color designations were based on the Rock-Color Chart of the National Research Council (Goddard and others, 1948).

To achieve optimum statistical reliability, 300 points on each thin section were counted for quartz, feldspars, apatite, clay minerals (matrix), carbonate minerals, iron oxides, and accessory minerals. The totals were normalized to 100 percent and are included in the stratigraphic sections. Owing to the inherent nature of mudrocks and for the purpose of this study, the cement, unless easily discernible, was counted and included with the matrix.

Each thin section was assigned to one of seven rock types on the basis of mineral composition, grain size, and texture; these types are: sandstone, siltstone, mudstone, claystone, phosphorite, wackestone, and grainstone, all of which are described in "Stratigraphic Sections."

Water-smear mounts on glass slides were made from each whole-rock sample for $\mathrm{X}$-ray analysis. To allow comparisons to be made between each sample, 15 milligrams of powdered whole rock samples were used. Clay separates of 12 previously determined smectite-rich samples from trench 100 were prepared for semiquantitative clay mineral analysis using methods described by Carroll (1970). Clay samples were glycolated and analyzed by $\mathrm{X}$-ray diffraction between $63^{\circ} 2 \theta$ and $60^{\circ} 2 \theta$ at a chart speed of $1 / 4$ inch per second and a $2 \theta$ scan speed of $1 / 4$ degree per minute to determine the $(060)$ $d$ spacing and thereby determine whether the clays were $\mathrm{Al}^{3+}, \mathrm{Mg}^{2+}$, or $\mathrm{Fe}^{2+}$-rich clays. X-ray diffractograms were produced by using copper radiation generated at $45 \mathrm{kv}$ and $14 \mathrm{ma}, 400$ counts per second, and a scanning rate of 1 degree per minute. Uniform response of the Philips Norelco' $\mathrm{X}$-ray diffractometer was maintained by periodic zero setting of the scalar rate meter. Peak positions in degrees $2 \theta$ were corrected using the difference between the true quartz peak positions and observed quartz peak positions. The determination of $d$ spacings was made with CuK alpha 1 wave length.

\footnotetext{
' Any use of trade names is for descriptive purposes only and does not imply endorsement by the U.S. Geological Survey.
}

\section{Definition of Terms}

The phosphate mineral in the marine apatite deposit near New Cuyama is carbonate fluorapatite. Throughout the deposit the mineral exhibits only a small range of compositional variation; therefore, the term "apatite" is often used in place of the full mineral name. The compositional rock terms used for phosphate-bearing rocks are classified on the quantity of apatite pellets, nodules, grains, and other phosphate material-the phosphatic framework-and apatite matrix that they contain. These terms are defined in the glossary.

The definition of porcellanite is based on the works of Bramlette (1946), Murata and Nakata (1974), and Murata and Larson (1975). Much of the porcellanite in the study area consists of opal-CT; 70 percent of the beds in the upper phosphatic mudstone member reference section (trench 100) contain opal-CT. The definition of opal-CT is based on that of Jones and Segnit (1971).

The definitions of the clastic rocks are included in the glossary. The terminology for claystone, mudstone, siltstone, and sandstone is based on that of Folk (1957), and the definitions of wackestone and grainstone are based on that of Dunham (1962, p. 118).

Textural modifiers, such as muddy, sandy, and silty, indicate the type and amount of admixture not indicated by the rock name. The definitions of muddy and silty are from Krynine (1948, p. 141); these definitions are included in the glossary.

The terminology used to describe the thickness of bedding of the rocks is modified from Maher (1959). The standards used for beds and laminae are included in the glossary.

Grain shape and angularity are in accord with the roundness scale of Powers (1953). The scale for the grain sizes is in the glossary. The terms used to describe the sorting of grains are also in the glossary. Distributions of grains sizes were determined by conventional sieve and pipette analyses or microscopically with an eyepiece micrometer.

The standard used in describing the relative abundance of fossils, and of some minerals, mineral groups, or other material, from very abundant to very rare, is in the glossary.

The range of unit hardness was very arbitrarily assigned; essentially it was determined on the amount of matrix alteration and the type of cementation. The following terms were used: indurated, moderately indurated, weakly indurated, and friable.

\section{GEOLOGIC SETTING}

Marine phosphatic rocks are distributed throughout the world and range in age from Precambrian to Quaternary. Marine phosphatic rocks in California are presently known in sedimentary sequences that range in age from Ordovician to Quaternary (Roberts, 1981); the best developed and most 


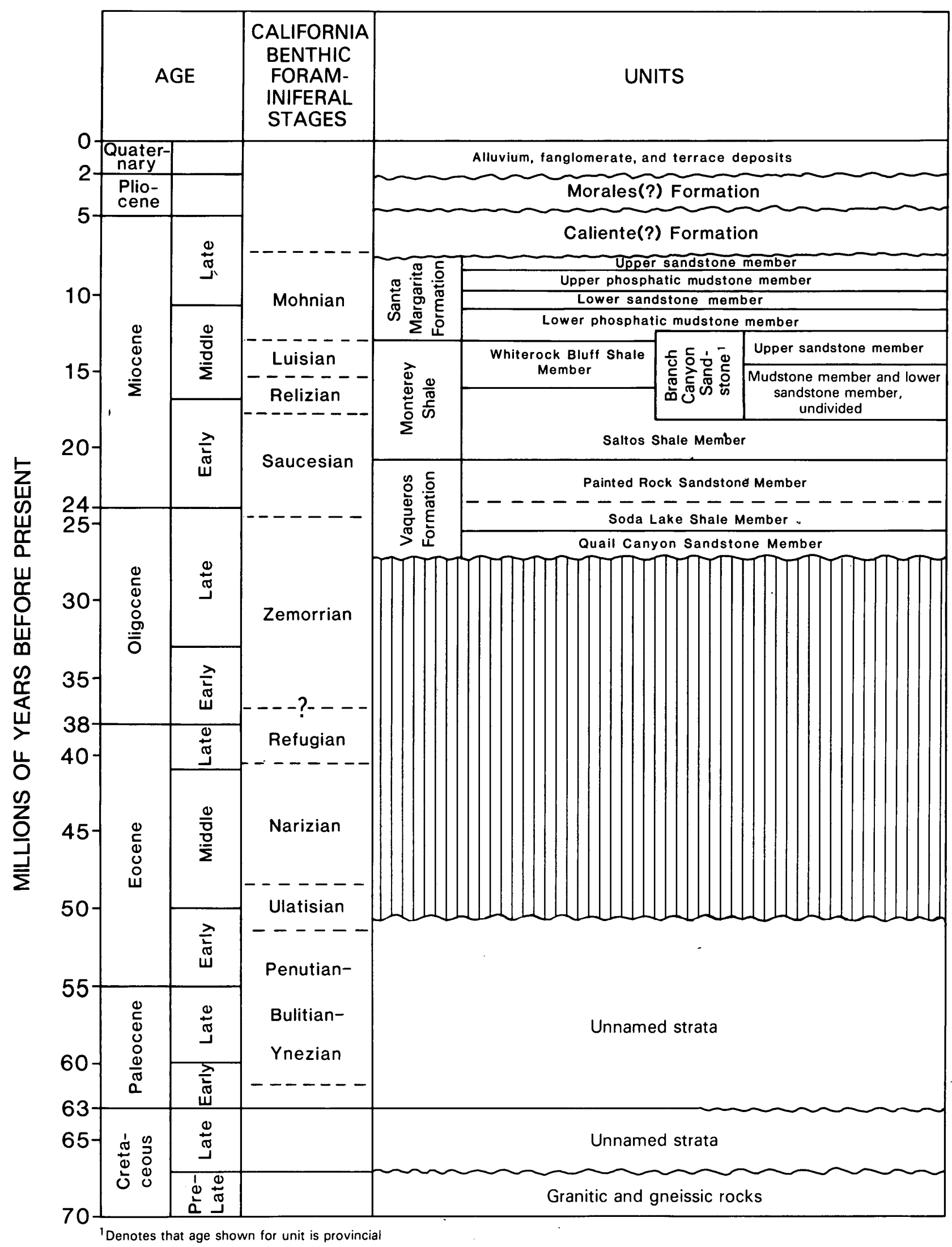

Figure 2. Generalized stratigraphic column of the Cuyama Valley phosphate area and surrounding region, Santa Barbara County, Calif. (Modified from Vedder, 1968, 1973; Vedder and Repenning, 1975.) 
widespread phosphatic rocks are in formations of Miocene age. The principal phosphate deposits occur in the following units: the Santos Shale Member of the Temblor Formation (Oligocene and lower Miocene) in the Temblor Range, the Sandholdt Member of the Monterey Formation (middle Miocene) in the Santa Lucia and La Panza Ranges, and the phosphatic members of the Santa Margarita Formation (upper Miocene) in the Sierra Madre and San Rafael Mountains.

\section{Stratigraphic Summary}

The distribution of many complexly interrelated rock units in the southern California Coast Ranges represents an intricate geologic history. In or adjacent to the study area preLate Cretaceous granitic and gneissic rocks form the basement complex. These rocks, lying between the San Andreas and the Sur-Nacimiento faults (Vedder and Brown, 1968; Page, 1970; 1981; Dibblee, 1973b; 1976), were designated the Salinia [Salinian] block by Reed (1933). Hill and others (1958, p. 2976) assumed that the granitic rocks were the basement complex beneath the Cuyama Valley. Isotope studies $[\mathrm{Rb} / \mathrm{Sr}$ and $\mathrm{U} / \mathrm{Pb}]$ by Ross (1978, p. 519) indicate an age of 100-110 m.y. for the basement complex (fig. 2).

The basement rocks in the southern part of the Salinian block are generally overlain by unnamed marine sedimentary rocks, such as the $5,000+\mathrm{ft}(1,525+\mathrm{m})$ thick sequence exposed in the northwestern La Panza Range that contains fossils diagnostic of Late Cretaceous age (Vedder and Brown, 1968). The Upper Cretaceous strata have a variety of marine and nonmarine lithofacies. In the La Panza Range exposures include massive conglomerate, sandstone, and mudstone deposited as shallow marine shelf deposits and in turbidite sequences as a part of submarine fans (Howell and others, 1977, p. 24). These deposits become thicker and finer grained to the southwest. This entire section of Cretaceous rocks is regionally truncated northeastward by younger strata. In the Quatal Canyon at the east end of Cuyama Valley, Oligocene and Miocene nonmarine sedimentary rocks of the Caliente Formation overlie the granitic basement.

South of the Cuyama Valley about $25,000 \mathrm{ft}(7,625 \mathrm{~m})$ of sandstone and mudstone assigned to the Paleocene and Eocene overlie the Upper Cretaceous series (Vedder, 1973, p. 42). This sequence of unnamed marine slope and basin sediments is approximately half sandstone and the other half is about equal amounts of conglomerate, siltstone, and mudstone (Fritsche, 1969, p. 18). The sandstone is generally medium- to coarse-grained, light-olive-gray, impure arkose. The siltstone and mudstone are olive-gray to dark-gray graywacke. The conglomerate varies from greenish- to brownish-gray and consists of subangular to rounded clasts of igneous and metamorphic rocks. In the La Panza Range, Paleocene strata apparently conformably overlie Upper Cretaceous rocks (Howell and others, 1977, p. 23); in the Sierra Madre Mountains the contact is buried.
The Paleocene and Eocene series is unconformably overlain by the non-marine Simmler Formation and marine Vaqueros Formation in the Cuyama Valley area. In the subsurface at the South Cuyama oil field, the Vaqueros Formation ranges from 320 to $830 \mathrm{ft}$ (100 to $250 \mathrm{~m}$ ) in thickness and has been subdivided into the Quail Canyon Sandstone, Soda Lake Shale, and Painted Rock Sandstone Members (Hill and others, 1958; Dibblee, 1973b) (fig. 2). The Vaqueros Formation south of the study area in the Sierra Madre Mountains, which is predominantly sandstone, has not been divided into members. The thickness of the Sierra Madre Mountains sequence ranges from 250 to $700 \mathrm{ft}$ ( 75 to $215 \mathrm{~m}$ ). These rocks probably correlate with the Painted Rock Sandstone Member as described and mapped by Fritsche (1969).

The Quail Canyon Sandstone Member beneath the Cuyama Valley consists of thick-bedded, fine- to mediumgrained, well-sorted, greenish-gray to light-gray, calcareous sandstone. Beds are often lenticular and locally cross-stratified. Thin interbeds of dark-gray or dark-brown siltstone are present locally. The thickness of this member in the South Cuyama oil field is $60 \mathrm{ft}(18 \mathrm{~m})$ (Zulberti, 1954, pl. 3). The Quail Canyon Sandstone Member contains sparse mollusks, including Pecten magnolia; the mollusks are suggestive of a provincial early Miocene age (Vedder and Repenning, 1975). Vedder (oral commun., 1982) presently regards these fossils as late Zemorrian (late Oligocene) on the basis of international correlation data.

The Soda Lake Shale Member is an indurated, darkbrown to black mudstone or siltstone with a few thin calcareous-cemented sandstone beds. Cores from wells drilled in the South Cuyama oil field contained sporadic phosphatic pellets in this member. The Soda Lake in the South Cuyama oil field ranges from 80 to $250 \mathrm{ft}$ ( 25 to $75 \mathrm{~m}$ ) in thickness (Zulberti, 1954, pl. 3). The upper part of this member contains a meager assemblage of lower bathyal early Saucesian foraminiferal fauna (Hill and others, 1958, p. 2986; R. L. Pierce in Dibblee, 1973b, p. 18).

Conformably overlying the Soda Lake Shale Member in the Cuyama Valley area is the Painted Rock Sandstone Member. In this area it is composed predominantly of sandstone that is thin to thick bedded, fine to coarse grained, and locally clayey or silty. The rocks are composed of poorly to fairly sorted, subangular grains (mostly quartz and feldspar). They are calcareous, friable to indurated, and include occasional siltstone interbeds. The Painted Rock ranges from 200 to $520 \mathrm{ft}(60$ to $160 \mathrm{~m})$ in thickness in the South Cuyama oil field (Zulberti, 1954, pl. 3) and is $700 \mathrm{ft}(215 \mathrm{~m})$ thick in the Sierra Madre foothills (Fritsche, 1969, p. 38). North of the Cuyama Valley, the Painted Rock, which contains early Miocene marine mollusks and Saucesian foraminifers (Vedder and Repenning, 1975), is as much as 5,500 $\mathrm{ft}(1,678 \mathrm{~m})$ thick (Vedder, 1973).

Oil and gas production at the South Cuyama oil field is primarily from the Painted Rock Sandstone Member, locally designated the Dibblee oil zone (Eckis, 1952; Zulberti, 
1954). Lesser production at this field is from the Quail Canyon Sandstone Member known locally as the Colgrove oil zone (Eckis, 1952; Zulberti, 1954; Hill and others, 1958, p. 2984).

Sedimentary rocks conformably overlying the Vaqueros Formation in the Cuyama Valley area had a very complex depositional history of transgression and regression. The change in sedimentation from coarse- to fine-grained clastic deposits was gradual in some areas but abrupt in others. Sandstone lenses and tongues that are lithologically similar to the Painted Rock are present in the lower part of the Saltos Shale Member of the Monterey Shale. Also, the Saltos in this area has two distinct intertonguing sequences, one is brownish-gray, laminated to indistinctly bedded, indurated siltstone and mudstone sequence and the other is a massive, gray, friable to indurated, sandy claystone sequence. According to the subsurface data, the brownish-gray siltstone and mudstone is the dominant lithology. Interpreted well data from the South Cuyama oil field indicates that the Saltos Shale Member has a thickness of $400 \mathrm{ft}(120 \mathrm{~m})$. In the study area the Saltos contains Relizian foraminifers (Vedder and Repenning, 1975).

Conformably overlying the Saltos Shale Member in the study area is the lower sandstone member of the Branch Canyon Sandstone or the Whiterock Bluff Shale Member of the Monterey Shale (fig. 2). Recurring marine sand deposition formed interfingering coarse-grained clastic materials (Branch Canyon Sandstone) with very fine grained clastic materials (Whiterock Bluff Shale Member).

In the Cuyama Valley the Whiterock Bluff Shale Member is composed of 300 to $700 \mathrm{ft}$ (90 to $215 \mathrm{~m}$ ) of platy siliceous shale, cherty shale, and diatomaceous shale. The Whiterock Bluff grades into the underlying Saltos and contains foraminifers diagnostic of late Relizian and Luisian Stages (Hill and others, 1958, p. 2991).

A thick marine sandstone sequence exposed in Branch Canyon adjacent to the South Cuyama oil field was named the Branch Canyon "Formation" by Hill and others (1958, p. 2991). The formation intertongues southwestward with deeper water marine units of the Monterey Shale and Santa Margarita Formation (fig. 2) and northeastward into the nonmarine Caliente Formation. These depositional relations, supplemented by invertebrate fauna and sedimentary structures, suggest a nearshore coastal environment (Clifton, 1968, p. 185). In the area of the type section, the sequence is $3,800 \mathrm{ft}(1,160 \mathrm{~m})$ thick (Vedder, 1973, p. 48) and consists of four unnamed mappable members (Vedder and Repenning, 1975). They are fine- to coarse-grained, locally conglomeratic, generally light-gray to pale-yellowish-gray, thick-bedded to massive, calcareous sandstone units with a few interbeds of siltstone and mudstone. Mollusks and echinoids from these units are provincial middle to late Miocene in age (Vedder and Repenning, 1975).

Conformably overlying the Monterey Shale and the Branch Canyon Sandstone in the foothills of the Sierra Madre
Mountains and in the subsurface of Cuyama Valley is the Santa Margarita Formation (fig. 2). This formation, which is 1,025 to $1,500 \mathrm{ft}$ ( 315 to $460 \mathrm{~m}$ ) thick, is subdivided into two sandstone members and two phosphatic mudstone members (Hill and others, 1958, p. 2996; Vedder and Repenning, 1975). The sandstone units, which are lithologically similar to the sandstone in the Branch Canyon Sandstone, indicate a continuing clastic source. The phosphatic mudstones suggest intervening tectonic stability accompanied with a decrease in coarse-grained clastic sediments. According to Vedder and Repenning (1975), the sandstone members contain late Miocene mollusks and echinoids and the phosphatic mudstones contain provincial late Miocene foraminifers and diatoms (see section on "Fauna and Age").

North of the Cuyama Valley, in the southern part of the Caliente Range, is $4,200 \mathrm{ft}(1,280 \mathrm{~m})$ of varicolored nonmarine conglomerate, sandstone, claystone, and basalt flows of the Caliente Formation (Hill and others, 1958, p. 2993). These nonmarine units extend southward interfingering with marine units of the Branch Canyon and Santa Margarita Formations. In the study area a $400 \mathrm{ft}(125 \mathrm{~m})$ thick nonmarine sequence of pinkish-gray sandstone and reddishbrown mudstone unconformably overlies the Santa Margarita Formation. This unit was questionably correlated with the upper part of the Caliente Formation by Vedder and Repenning (1975).

In the Cuyama Valley and Sierra Madre foothills, the upper Miocene formations are unconformably overlain by continental deposits of gravel, sand, and silt of the Morales(?) Formation (Hill and others, 1958, p. 2997). These sedimentary deposits, which are poorly consolidated, contain abundant clasts from underlying formations and were probably deposited as alluvial fans and a floodplain. In the study area this sequence is approximately $1,500 \mathrm{ft}(460 \mathrm{~m})$ thick. The Morales(?) Formation, which unconformably overlies folded upper Miocene strata and is unconformably overlain by lower Pleistocene strata (Hill and others, 1958, p. 2998), is probably Pliocene in age.

In the study area the Morales(?) Formation is unconformably overlain by semiconsolidated gravel, sand, and silt derived from older rocks in the Sierra Madre Mountains and deposited in the foothills and Cuyama Valley as fanglomerate deposits (Hill and others, 1958, p. 2998) and terraces. These deposits vary in color from olive gray to reddish brown and range in thickness from 0 to $900 \mathrm{ft}(0$ to $275 \mathrm{~m}$ ). The age of the fanglomerate deposits and terraces is post-Morales and prealluvium, probably Pleistocene.

\section{Structural Summary}

The structural history of the Salinian block (fig. 3 ) is complicated. The complexity is due essentially to the boundary fault systems of the block, relief features on the basementcomplex surface, intensive folding of post-basement strata, extensive regional erosion, and late Tertiary cover (Graham, 


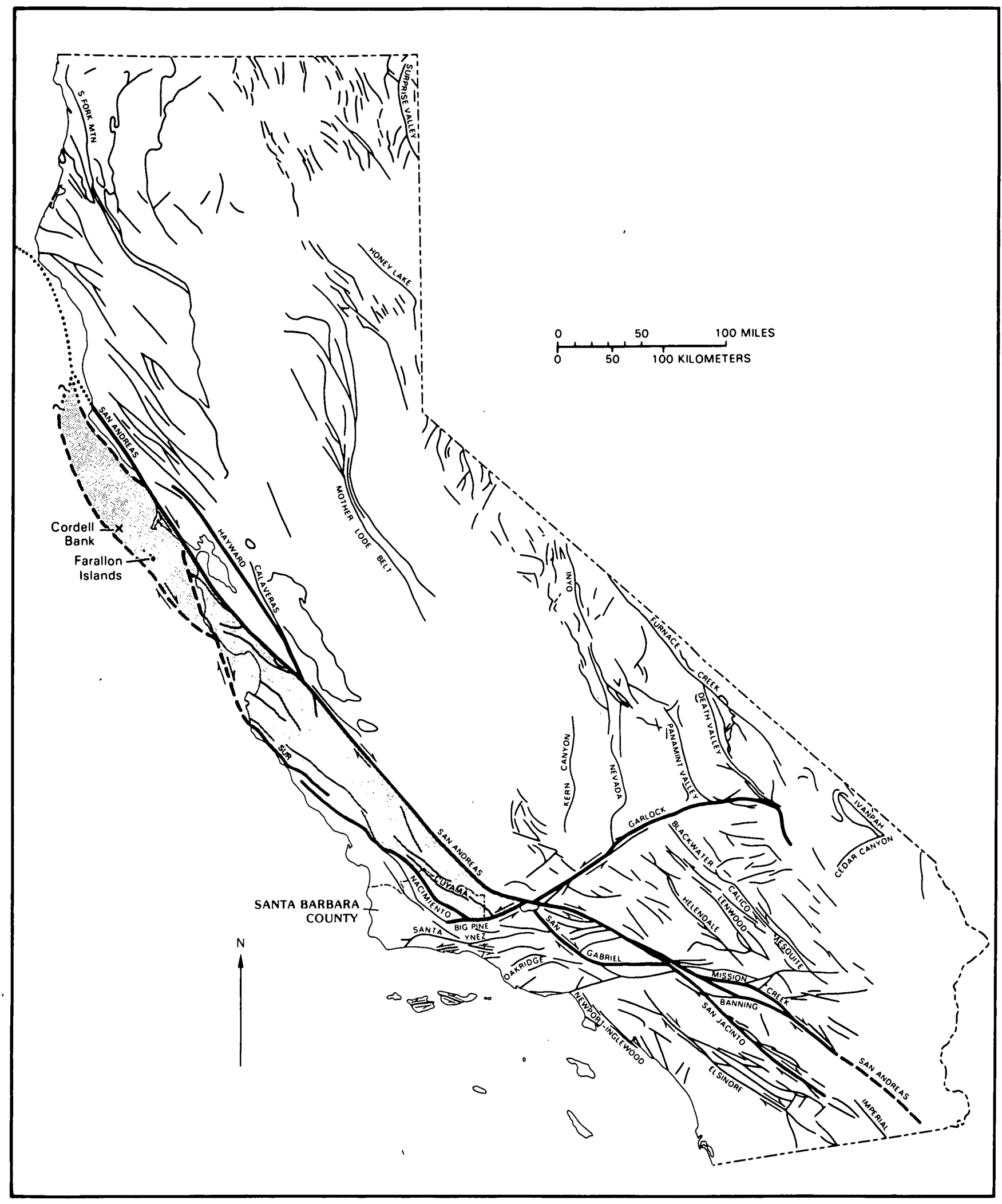

Figure 3. Relation of Salinian block (shaded) to faults in California (modified after Ross, 1978). 
1976). Interaction with adjoining crustal blocks caused recurring uplift or subsidence of the Salinian block and produced extensive compression, faulting, and folding concurrently with erosion and sedimentation.

The Salinian block is a crustal unit of dominantly granitic rocks. Along its fault boundaries, three slices that contain abundant gneissic rocks have been identified by Ross (1972, p. 34). The basement complex of the Salinian block is devoid of the Franciscan Complex and ultramafic rocks that form the basement in adjoining blocks. The northeast boundary is delimited by the San Andreas fault zone.

Atwater (1970) described the San Andreas as a transform system forming a crustal plate boundary. Episodic movement along this Neogene boundary resulted in a complex structural evolution of basin development and deformation on the Salinian block. Movement associated with the Salinian block migrating relatively northwestward influenced the sedimentary processes by changing sediment source areas and rates of sedimentation. Hill and Dibblee (1953, p. 448) postulated a cumulative right-lateral slip of several hundred miles along this system. Authors (Dickinson and Grantz, 1968) presented a variety of evidence in support of Hill and Dibblee's estimate. Wentworth (1968) examined Upper Cretaceous and lower Tertiary rocks along parts of the fault and inferred a right slip of at least $270 \mathrm{mi}(435 \mathrm{~km})$ since Late Cretaceous. Addicott (1968), after examining the middle Tertiary rocks along the fault, suggested a right slip of $200 \mathrm{mi}$ $(320 \mathrm{~km})$ since the Oligocene, $170 \mathrm{mi}(275 \mathrm{~km})$ since the early Miocene, $130 \mathrm{mi}(210 \mathrm{~km})$ since the middle Miocene, and $80 \mathrm{mi}(130 \mathrm{~km})$ since the late Miocene.

The southwest boundary of the Salinian block is controlled by the complex and poorly defined Sur-Nacimiento fault system that also had a dominant influence on the area's sedimentation. Although this northwest-trending fault system parallels the San Andreas, it had a much different history. The long and complicated record of recurrent activity of differing types of movement was investigated by Vedder and Brown (1968), Page (1970, 1981), Champion and others (1980), Howell and others (1980), and Vedder and others (1980). Stratigraphic evidence along the Nacimiento fault demonstrates large dip-slip and inconclusive strike-slip movements in the interval from post-Late Cretaceous to Miocene time. Late Cretaceous suturing of the Salinian block and its western neighbor followed by large-scale post-Campanian to early Eocene northward translation has been proposed by Champion and others (1980), Howell and others (1980), and Vedder and others (1980).

Recurring strike-slip and dip-slip displacements on the boundary systems and consequent vertical movements on shear faults provided continuing changes in topographic relief on the Salinian block. The distribution of sedimentary formations in contact with the Salinian granitic rocks shows progressive burial on an irregular basement surface.

The preserved rock sequence for the Cuyama Valley segment of the southern part of the Salinian block consists of four groups of sedimentary rocks: Upper Cretaceous, Paleocene and Eocene, Miocene, and post-Miocene. These groups are discussed briefly in "Stratigraphic Summary" but are mentioned here to emphasize the unconformities separating these groups, the unconformable angularity of preMiocene groups, and the abrupt lithofacies changes, particularly within the Miocene groups (fig. 2). These lithofacies changes suggest periods of intermittent deformation along the reactivated boundary fault systems. Clifton (1968, p. 183; 1981) attributed cyclic deposition of middle and probably upper Miocene nearshore marine and beach environments along the northern margin of the Salinas-Cuyama basin to repeated movement on the San Andreas fault.

Upper Cretaceous strata apparently were derived largely from uplifted granitic segments forming the basement of the Salinian block. Overlying the Upper Cretaceous strata is a thick sequence of Paleocene and Eocene rocks derived from granitic basement and recycled Upper Cretaceous rocks. Unconformably overlying the Upper Cretaceous, Eocene, or granitic rocks is a thick sequence of Oligocene nonmarine strata, Miocene marine and nonmarine strata, and volcanic flows deposited in a trough or basin. At the end of the Miocene, uplift in the Caliente Range and the Sierra Madre Mountains renewed erosion and spread debris from the two ranges into the Cuyama Valley forming the thick Pliocene(?) alluvial deposits. Further tectonic activity during the Pleistocene folded and faulted the area. Continuing erosion covered the valley and adjacent foothills with Quaternary deposits.

Middle Tertiary downwarping between the boundary fault systems developed a long narrow depression in the southern part of the Salinian block. Regional paleogeographic studies by Addicott (1968) indicate the general limits of this tectonic feature. It has been referred to as the Cuyama trough by English (1916, p. 207); as the Caliente trough by Eaton (1939, p. 258) and by Eaton and others (1941, p. 198); as the Salinas-Cuyama basin by Schwade and others (1958, p. 78); as the Carrizo-Cuyama basin by Cross (1962, p. 27) and Gribi (1963, p. 16); the Salinas basin by Graham (1978, p. 2216); and the Salinas basin and Caliente basin by Blake and others (1978, p. 349). Addicott's (1968, p. 153, 156) middle and late Miocene paleogeographic maps support the designation of Salinas-Cuyama basin by Schwade and others (1958) for that time period, and their terminology is used herein.

Detailed quadrangle mapping in the Cuyama Valley and bordering Sierra Madre Mountains and Caliente Range by Vedder and Repenning (1975) indicates that the Cuyama Valley is the surface expression of a large northwest-trending asymmetric synclinal trough. This trough, a structural feature within the Salinas-Cuyama basin, is deepened between the Whiterock and Morales fault systems on the north and the South Cuyama and Ozena fault systems on the south. Between these fault systems are older buried faults, such as the Russell fault along which Vedder (1973, p. 47) inferred as 
much as $14 \mathrm{mi}(22.5 \mathrm{~km})$ of strike-slip offset of Miocene and older rocks.

The phosphate-bearing Santa Margarita Formation has been folded into northwest-trending anticlines and synclines by compression from the southwest (pl. 3). Throughout much of the area, formational attitudes are nearly vertical or overturned (pl. 2). The area is cut by northwest-trending faults that parallel the axes of the folds and by faults that cut obliquely across the limbs of the folds (Vedder and Repenning, 1975; pl. 1).

\section{SANTA MARGARITA FORMATION}

\section{General Features}

Massive sandstone and interbedded mudstone exposed near the town of Santa Margarita in San Luis Obispo County were first described by Antisell (1856, p. 44). These strata, in the San Luis Obispo quadrangle, were later mapped by Fairbanks (1904), who formally named them the Santa Margarita Formation. In a study of the stratigraphy and fossils of the Santa Margarita Formation, Richards (1933) specified the location of the type section and presented summaries of previous stratigraphic and paleontologic work. Many subsequent studies of the Santa Margarita and its stratigraphic equivalent have been made throughout the southern Coast Ranges. For a comprehensive review of these studies and for an inclusive regional examination of the Santa Margarita Formation, the reader is referred to the detailed sedimentologic study of Phillips (1981). For an account of the progradational sequences in Miocene shoreline deposits in the southeastern Caliente Range, the reader is referred to Clifton (1981). His discussion of the transgressive-regressive episodes based on observations of the well-exposed sedimentary rocks of the Caliente Range is also pertinent to the middle and upper Miocene sequences in Cuyama Valley.

The Santa Margarita Formation in the Cuyama Valley was first geologically mapped and described by English (1916). In this early study, he recognized some of the rapid lateral facies changes. English (1916, p. 195) attributed the varying lithology of the sedimentary sequence to erosion of the mainland and offshore islands because of differential movements of subsidence and uplift that formed related areas of deposition. He (1916) included the Branch Canyon "Formation" in his definition of the Santa Margarita Formation whereas Hill and others (1958) included the Santa Margarita in the upper part of their Branch Canyon "Formation".

The Santa Margarita Formation ranges from 1,025 to $1,500 \mathrm{ft}(315$ to $460 \mathrm{~m})$ in thickness and averages $1,350 \mathrm{ft}$ $(410 \mathrm{~m})$ thick in the study area. The lower phosphatic mudstone member is approximately $150 \mathrm{ft}(45 \mathrm{~m})$ thick at the South Cuyama oil field; however, the member gradually thins eastward and pinches out in the vicinity of Goode Canyon in the northwest corner of the Fox Mountain quadrangle (imme- diately east of the Salisbury Potrero quadrangle) (Vedder, 1968; Fritsche, 1969, p. 155). The lower sandstone member is generally $450 \mathrm{ft}(135 \mathrm{~m})$ thick. The upper phosphatic mudstone member is $160 \mathrm{ft}(50 \mathrm{~m})$ thick in the northwestern part of the study area (trench 297, in "Stratigraphic Sections"), $275 \mathrm{ft}(85 \mathrm{~m})$ thick near the center of the study area (trench 100, in "Stratigraphic Sections"), and $195 \mathrm{ft}(60 \mathrm{~m})$ thick at the southeastern part of the study area (trench 296, in "Stratigraphic Sections"). The upper sandstone member ranges from 200 to $350 \mathrm{ft}$ ( 60 to $105 \mathrm{~m}$ ) in thickness owing to truncation by the overlying unit. Northeastward from the study area all members of the Santa Margarita interfinger with the upper part of the nonmarine Caliente Formation (Vedder and Repenning, 1975). Eastward and southward the Santa Margarita is truncated by younger rocks (Vedder, 1968; Fritsche, 1969). Northwestward the Santa Margarita continues intermittently as a mappable unit in exposures approximately parallel to the axis of the Salinas-Cuyama basin (Dibblee, 1973a).

The Santa Margarita Formation conformably overlies the Monterey Shale and Branch Canyon Sandstone in the central part of the Cuyama Valley (fig. 2). In the northern part of the valley at the Russell Ranch oil field, the Santa Margarita rests conformably upon the Whiterock Bluff Shale Member of the Monterey Shale. The Whiterock Bluff grades laterally into the Branch Canyon Sandstone southeastward to the Cuyama Valley phosphate area and northeastward to the Caliente Range. Both members of the Monterey Shale grade into the Branch Canyon Sandstone eastward from the Cuyama Valley phosphate area. Farther eastward, in the vicinity of the Cuyama Badlands, the Branch Canyon grades into the nonmarine Caliente Formation.

At the Cuyama Valley phosphate area the marine sequence of the Santa Margarita Formation grades into the upper part of the nonmarine Caliente Formation northeastward to the Caliente Range and eastward to the Cuyama Badlands. Northwestward from the Cuyama Valley phosphate area, the Santa Margarita maintains a similar lithology and marine fauna suggesting a northwest-southeast strandline direction during deposition. The Santa Margarita Formation is unconformably overlain by a westernmost nonmarine tongue at the top of the Caliente(?) Formation (Vedder and Repenning, 1975) in the Cuyama Valley phosphate area. Elsewhere in the Cuyama Valley, the Santa Margarita is unconformably overlain by nonmarine beds of the Morales(?) Formation.

In the Cuyama Valley area, the Santa Margarita Formation consists of four members that represent two distinct paleoenvironments defined by different sedimentary and paleontologic characteristics. The sandstone members contain intertidal to shallow-water assemblages of mollusks, pelecypods, echinoids, and diatoms indicative of a marine shelfsand environment. The phosphatic mudstone members represent periods of greater tectonic stability with a consequent decrease in sediment volume than the sandstone members. 
Faunal assemblages of mollusks and diatoms in the phosphatic mudstone members suggest a marine offshore environment of a slightly deeper water shelf-mud environment than the sandstone members.

\section{Fauna and Age}

Megafossils are common to rare in members of the Santa Margarita Formation in the study area. Faunas were collected from this area and described by English (1916, p. 204), Eaton and others (1941, p. 242), Fritsche (1969, p. 169), and Vedder and Repenning (1975). Fossil collections in support of geologic mapping in the study area by Fritsche (1969) and Vedder and Repenning (1975) provided the stratigraphic framework for this report. Faunas collected and identified by Fritsche (1969), and Vedder and Repenning (1975) from representative localities of members of the Santa Margarita Formation are listed below:

Lower phosphatic mudstone member (Member A of Fritsche; claystone and shale member of Vedder and Repenning)

Crassostrea ashleyi (Hertlein)

Clementia pertenuis (Gabb)

Aequipecten cf. A. discus (Conrad)

Unidentified tellinid

Nondiagnostic shallow-water foraminifers

Lower sandstone member (Member B of Fritsche; sandstone and conglomerate member of Vedder and Repenning)

Forreria carisaensis (Anderson)

Crassostrea eucorrugata (Hertlein)

Crassostrea titan (Conrad)

Crassostrea sp.

Lyropecten estrellanus (Conrad)

Unidentified pectinid

Astrodapsis sp.

Isurus sp.

Desmostylus cf. $D$ hesperus Marsh

Upper phosphatic mudstone member (Member C of Fritsche; claystone and clayey siltstone member of Vedder and Repenning)

Crassostrea titan (Conrad)

Lucinisca cf. L. nuttalli (Conrad)

Chione temblorensis (Anderson)

Clementia pertenuis (Gabb)

Yoldia cooperii supramontereyensis Arnold

Unidentified tellinid

Nondiagnostic shallow-water foraminifers

Coscinodiscus

Upper sandstone member (Member D of Fritsche; sandstone member of Vedder and Repenning)

Turritella carrisaensis Anderson and Martin

Turritella sp.

Crassostrea sp.
Unidentified pectinid

Balanus sp.

Astrodapsis whitneyi Remond

Astrodapsis sp.

Undifferentiated Santa Margarita Formation of Fritsche

Unidentified bryozoan

Yoldia cooperii supramontereyensis Arnold

Anadara sp.

Modiolus sp.

Crassostrea titan (Conrad)

Crassostrea sp.

Chlamys cf. C. proavus (Arnold)

Lyropecten estrellanus (Conrad)

Lucinisca cf. L. nuttalli (Conrad)

Chione temblorensis (Anderson)

Clementia pertenuis (Gabb)

Spisula catilliformis Conrad

Cryptomya ovalis Conrad(?)

Panopea generosa Gould

Panopea tenuis Wiedey

Unidentified pectinid

Unidentified tellinid

Astrodapsis sp.

The above faunal collections from the Santa Margarita Formation in the study area are generally indicative of provincial late Miocene age. This faunal assemblage is characteristic of a shallow-water marine environment in a warm temperate to subtropical climate.

\section{Lithologic Composition}

\section{Lower Phosphatic Mudstone Member}

The lower phosphatic mudstone member of the Santa Margarita Formation is poorly exposed in the study area. Subsurface information at the South Cuyama oil field indicates a thickness of 150 feet $(45 \mathrm{~m})$. Field mapping of Vedder (1968) and Fritsche (1969) shows that the lower phosphatic mudstone member thins eastward and pinches out in the Fox Mountain quadrangle. In the limited exposures the member is predominantly a phosphatic, siliceous mudstone with less than 30 percent interbedded siltstone, sandstone, and conglomerate. Outcrops are olive gray to greenish gray on fresh surfaces and yellowish gray on weathered surfaces. Individual lithologic units are laminated to thin bedded or indistinctly bedded. Most of the siltstone and sandstone beds contain angular to subangular grains which are medium sorted. The sandstone units are often cross laminated. They are fine to medium grained with lenses of coarse-grained sandstone and pebble conglomerate. The member contains only thin pelletal and nodular phosphorite zones with local concentrations at or near the base; therefore, it is not considered a potential phosphate resource. 


\section{Lower Sandstone Member}

The lower sandstone member of the Santa Margarita Formation forms many of the foothills in the study area and is generally exposed in canyons. The member is predominantly sandstone with less than 20 percent interbedded mudstone and conglomerate. Outcrops are light gray on fresh surfaces and very pale orange to yellowish orange on weathered surfaces. Individual beds are medium bedded to massive with lenses of mudstone or conglomerate. The sandstone units are medium sorted and contain subangular, fine- to mediumgrained quartz, orthoclase, plagioclase, and igneous and metamorphic rock fragments. The conglomerate beds, which are poorly sorted, consist mainly of subrounded pebbles of predominantly granitic and metamorphic rocks, and a few pebbles of sandstone, volcanic rocks, and shell fragments. The cement in the sandstone is generally siliceous; the beds with calcareous cement contain common to abundant megafossils. Fossil beds are dominated by Crassostrea titan and Lyropecten estrellanus. The member contains local concentrations of phosphate pellets and phosphatic casts of mollusks near its base.

\section{Upper Phosphatic Mudstone member}

The upper phosphatic mudstone member of the Santa Margarita Formation is poorly exposed in the study area; however, eight stratigraphic sections were obtained for study by trenching (see "Stratigraphic Sections" and pl. 5). In the reference section for this member (trench 100) the stratigraphic sequence consists of 50 percent mudstone, 25 percent siltstone, 10 percent claystone, 10 percent fine-grained sandstone, and 5 percent phosphorite and bentonite. Most beds are phosphatic and siliceous. The average specific gravity of the phosphorite beds is 2.26 . The lithologic units generally are laminated to thick-bedded, poorly to mediumsorted sedimentary rocks consisting of fine sand size to less than silt size, angular to subrounded grains. Most beds are light gray to olive gray or yellowish gray and weather to shades of grayish orange or moderate brown. The framework of the sedimentary rocks commonly consists of quartz and feldspar grains and lesser amounts of phosphatic pellets; the matrix consists of carbonate fluorapatite and minerals of clay, carbonate, and iron oxide. Most of the units are massive, probably bioturbated, and contain fragments of diatoms, fish bones and scales, sponge spicules, echinoid spines, and mollusk shells. The relation of the major chemical constituents and the lithologic composition for the upper phosphatic mudstone member is illustrated on plate 4 .

\section{Upper Sandstone Member}

The upper sandstone member of the Santa Margarita Formation forms the foothills along the southern boundary of the Cuyama Valley. The member is predominantly sandstone with less than 10 percent interbedded mudstone and conglomerate. Outcrops are light gray and greenish gray on fresh surfaces and light yellowish gray on weathered surfaces. Individual beds are thick bedded and massive with lenses of greenish-gray mudstone, clayey sandstone, and conglomerate. The sandstone units are poorly to medium sorted and contain subangular, very fine to coarse-size grains of quartz, orthoclase, plagioclase, and igneous and metamorphic rock fragments. Turritella carrisaensis is the most abundant megafossil in the fossil beds. The cement is generally siliceous and only locally calcareous. Some sandstone beds are cross stratified. The member also contains a few thin bentonite and bentonitic siltstone beds. In the lower part of the member phosphatic pellets are present in the fine-grained units (see "Stratigraphic Sections," trench 294).

\section{Mineralogy and Petrography of Phosphatic Components}

\section{Carbonate Fluorapatite}

Phosphatic components in the upper phosphatic mudstone member of the Santa Margarita Formation are pellets that range from 0.10 to $0.35 \mathrm{~mm}$ in diameter (median diameter is $0.20 \mathrm{~mm}$ ), nodules that range from 2.0 to 30.0 $\mathrm{mm}$ in diameter, and phosphatized diatoms and pelecypod casts. The pellets and nodules generally are structureless aggregates of submicrocrystalline carbonate fluorapatite, terrigenous clay-, silt-, and sand-size particles, and diatoms or shell fragments. The pelecypod casts are phosphatecemented sand grains that rarely contain foraminifers and sponge spicules. Although most mudstone and sandstone units are poorly sorted, zones containing the pellets are strikingly well sorted.

Phosphatic pellets, when examined in thin section, display a variety of shapes, boundaries, internal structures, and sizes. Pellets commonly have been compressed and deformed against one another by compaction. The shapes of these pellets vary from flattened ovals or elipsoids to very irregular or broken pieces. Ellipsoidal pellets, the most common shape, generally are preferentially oriented with the long axis (typically two times as long as the short axis) parallel to the bedding plane. Ellipsoidal and spherical pellets usually have grain inclusions, sharp boundaries, and a recognizable internal structure. Pellets that are irregular in shape commonly have diffuse boundaries and no recognizable internal structure. Pellets with an irregular shape and an indistinct boundary that seem to grade into the surrounding matrix are designated incipient pellets (Gulbrandsen, 1960, p. cl20).

Most of the phosphatic pellets have noncentered inclusions of detrital silt to fine sand-size grains of quartz and minor amounts of feldspar. The detrital grains commonly protrude the boundary of this pellet type. There are a few compound pellets made up of two or more pellets that are in contact and that have been encased by silica, carbonate, or 
apatite. A significant number of pellets have inclusions of diatomaceous debris or shell fragments. The cores of many of these pellets are the diatom Coscinodiscus; it is one of the more resistant diatoms to dissolution during the formation of phosphatic pellets (J. A. Barron, oral commun., 1979). Pellets containing a complete frustule of this diatom are generally larger than other types of pellets $(C$, pl. 6$)$.

The pellets and nodules are dark brown to dark gray on fresh surfaces and yellowish gray to light gray on weathered surfaces. The original color is essentially due to the presence of carbonaceous material and iron oxides, and the secondary color is due to the leaching of the carbonaceous material and alteration of the iron oxides.

Phosphatic ooliths occur with the phosphatic pellets, and externally they have a similar shape and size; however, internally they are strikingly dissimilar. Microscopically, ooliths show distinct concentric zonation by changes in color and refractive indices. This concentric structure is due mostly to alternating bands of apatite of different crystallinity. Because ooliths represent a minor fraction of the pellet population, they are not separated in the point count percentages.

Nodules generally are subrounded, are ellipsoidal to irregular in shape, and are composed of apatite-cemented clay. Most nodules are granule $(2.0+\mathrm{mm})$ size; however, a few range in size from 1.0 to $2.0 \mathrm{~cm}$. In all the units of the upper phosphatic mudstone member that contained nodules, the finer grained clastic units (mudstone, claystone, and siltstone) contained 67 percent of the nodule occurrences; coarser grained clastic units (sandstones) contained 21 percent; and phosphorite units contained 4 percent.

Many of the phosphatic pellets have undergone diagenetic alteration ranging from slight boundary changes to complete mineral replacement. Some pellets have calcareous rims; a few have siliceous rims. In some units, continued alteration is marked by replacement to clay and iron oxide minerals. The progression of alteration of the pellets may have contributed to the growth of interstitial apatite in the surrounding matrix. In general, the cementing matrix between pellets or nodules is commonly phosphatic and less often siliceous, mainly anhedral submicron opal-CT. Opal-CT lepispheres rarely occur in voids on pellet surfaces.

\section{Diagenetic Alterations}

Investigation of the diagenetic alterations of the upper phosphatic mudstone member of the Santa Margarita Formation in trench 100 was conducted in an attempt to identify physiochemical changes that may have occurred within the sediments and pore fluids; in particular, the changes that may affect the $\mathrm{Ca} / \mathrm{Mg}$ ratio by providing sinks for magnesium and thus allowing the direct unimpeded precipitation of carbonate fluorapatite. Data indicate the presence of several diagenetic minerals, including opal-CT, dolomite, calcite, gypsum, mica group, and the smectite group minerals.
Investigations by Martens and Harriss (1970) have demonstrated that the presence of $\mathrm{Mg}^{2+}$ ions, above a critical value, inhibits the direct precipitation of crystalline carbonate fluorapatite. This critical value is always exceeded in the open ocean because of the relatively high concentration of magnesium in sea water. A magnesium sink must form if the $\mathrm{Ca} / \mathrm{Mg}$ ratio necessary for an uninhibited direct precipitation of crystalline carbonate fluorapatite is to be reached. Investigations by several researchers have shown that the $\mathrm{Mg}^{2+}$ concentration increases slightly in the top $50 \mathrm{~cm}$ then decreases with depth in the upper few meters of sediments (Bischoff and Sayles, 1972; Booth, 1974) while other researchers have noted a general decrease in concentration with depth in the upper few meters of sediment (Brooks and others, 1968; Bischoff and Ku, 1970). The decrease suggests that the $\mathrm{Mg}^{2+}$ ions are being progressively removed with depth by early diagenetic processes. Several possible diagenetic sinks may exist. Using chemical and mineralogical data, Drever (1974) postulated that the most important mechanism for the removal of magnesium from pore water is the exchange of magnesium with iron in sheet silicates. The conditions considered most favorable for this reaction are in anaerobic environments where the $\mathrm{Fe}^{2+}$ in the sheets reacts with $\mathrm{H}_{2} \mathrm{~S}$ to form pyrite and $\mathrm{Mg}^{2+}$ replaces the vacated sites (Drever, 1971). Alternatively, in a reducing environment, $\mathrm{Mg}^{2+}$ may be replacing $\mathrm{Fe}^{2+}$ in iron oxide sheaths that are not structurally bound to clays (Sholkovitz, 1972). Of less importance in the removal of magnesium may be the formation of $\mathrm{Mg}$-bearing carbonates, simple ion exchange, glauconite formation, and in situ formation of sepiolite and chlorite (Bischoff and Ku, 1970; Bischoff and Sayles, 1972). Another significant magnesium sink forms when volcanic ash alters to bentonite. As the alteration proceeds, magnesium is removed from the pore fluids and incorporated in montmorillonite (Ross and Hendricks, 1945). The formation of montmorillonite from ash may be significant for another reason as well as the removal of $\mathrm{Mg}^{2}+$. Such alterations occur in a relatively alkaline system (Slaughter and Earley, 1965) - a system where as the alkalinity increases the solubility of phosphate decreases (Gulbrandsen, 1969). Another sink for $\mathrm{Mg}^{2+}$ ions is the formation of embryonic opal-CT lepispheres around magnesium hydroxide nuclei (Kastner and others, 1977). Since opal-CT is present in 70 percent of the beds in the upper phosphatic mudstone member, a significant amount of magnesium may have been removed, albeit long after burial, from the pore solution by this mechanism.

Petrographic and $\mathrm{X}$-ray diffraction investigations did not conclusively establish a quantitatively sufficient amount of early diagenetic minerals to provide sinks for magnesium as to affect the $\mathrm{Ca} / \mathrm{Mg}$ ratio such that crystalline carbonate fluorapatite could precipitate directly from solution. However, post depositional changes in physiochemical conditions may have resulted in late diagenetic alteration or dissolution of the early diagenetic mineral sinks for magne- 
sium releasing $\mathrm{Mg}^{2+}$ back into solution. Perhaps the magnesium needed for opal-CT lepishere nucleation was provided by this mechanism.

Modern marine carbonate fluorapatite has been identified near the sediment water interface on the inner shelf of Southwest Africa (Baturin, 1969; Baturin and others, 1972; Price and Calvert, 1978) and Peru (Burnett, 1974; Manheim and others, 1975; Burnett and others, 1980). The area of formation is on the shelf and slope where an oxygen minimum zone impinges on the bottom, at depths of 330 to 1,640 $\mathrm{ft}(100$ to $500 \mathrm{~m})$ (Manheim and others, 1975, p. 245). Although phosphate is enriched in this zone, there is no unequivocal evidence for the direct precipitation of carbonate fluorapatite from sea water. Instead, recent experimental work (Gulbrandsen and others, 1984) demonstrates that an initial amorphous solid phase of calcium phosphate is formed (the magnesium concentration has no inhibiting affect on the formation of amorphous calcium phosphate (Martens and Harriss, 1970)) and develops into a crystalline magnesium phosphate, then it recrystallizes to carbonate fluorapatite with time. The recrystallization rate may be increased as magnesium is removed from the system, but the rate is not strictly dependent on the absolute raising of the $\mathrm{Ca} / \mathrm{Mg}$ ratio to the critical value. A decrease in free $\mathrm{Mg}^{2+}$ cations in the system favors the crystalline phase in the kinetic reaction between amorphous calcium phosphate and crystalline carbonate fluorapatite. Such an amorphous solid phase of calcium phosphate in a modern phosphogenic environment off Southwest Africa has been interpreted by Baturin (1971a) on the basis of $\mathrm{X}$-ray line broadening. Crystallization is accompanied by an increase in $\mathrm{P}_{2} \mathrm{O}_{5}, \mathrm{CaO}, \mathrm{CO}_{2}$, and $\mathrm{F}$ and a decrease in $\mathrm{Mg}$, organic C, and other elements (Baturin, 1971a). The changes in $\mathrm{X}$-ray patterns and composition are supported by the experimental results of Gulbrandsen and others (1984). Inherent in this mode of formation is the inclusion of impurities (R. A. Gulbrandsen, written commun., 1980), including organic matter, mineral fragments, and amorphous solids (pl. $6, C, D, E, G, H, I, M)$ in the phosphatic pellets.

\section{Opal-CT}

Opal-CT is present in 70 percent of the beds in the upper phosphatic mudstone member of the Santa Margarita Formation, trench 100, (see "Stratigraphic Sections") and is a major component in 26 percent of the beds. Its origin and occurrence provide valuable information on the late diagenetic processes that have effected the phosphate-bearing rocks of the Santa Margarita Formation. Bramlette (1946) introduced the concept of diagenetic alteration of siliceous oozes to form cristobalite and chert. The alteration occurs through the solution and redeposition of siliceous biogenic sediment, predominantly diatom frustules. The transformation was believed to be essentially dependent on the depth of burial, temperature, and time; however, it has been experimentally demonstrated (Kastner and others, 1977) that the rate of transformation from opal-A to opal-CT is increased when nuclei containing magnesium and hydroxyl are present. Nuclei with $\mathrm{Mg}: \mathrm{OH}=1: 2$ attract silanol groups and act as sites for opal-CT nucleation and subsequent growth of opal-CT lepispheres. A significant amount of magnesium may be removed from the pore solution by this process, even at a temperature of $50^{\circ} \mathrm{C}$ (Mariam Kastner, oral commun., 1980). Because magnesium acts as an inhibitor in the precipitation of carbonate fluorapatite (Martens and Harriss, 1970), the initiation of opal-CT lepisphere formation with magnesium hydroxide nuclei may be an important factor in late phosphogenesis. Murata and Larson (1975), using X-ray diffraction and SEM techniques on samples from a continuous sequence at Chico-Martinez Creek in the Temblor Range, Calif. confirmed Bramlette's (1946) observations and provided a subdivision of these siliceous rocks into three depth-controlled zones characterized by different polymorphs of silica. The three zones, in descending stratigraphic order, are: biogenic opal (opal-A of Jones and Segnit, 1971), diagenetic cristobalite (opal-CT of Jones and Segnit, 1971), and diagenetic quartz. Opal-CT undergoes a progressive decrease in the $d(101)$ spacing because of gradual solid-state adjustments in the internal crystal structure. X-ray diffraction analysis of opal-CT $d(101)$ spacing from a continuous section through the upper phosphatic mudstone member of the Santa Margarita Formation in trench 100 (see table 1) show a range in the $d(101)$ spacing from 4.123 to 4.085 angstroms. Figure 4 confirms the depth-related trend; solid state adjustments have led to a smaller more ordered $d(101)$ spacing at the base of the upper phosphatic mudstone member. The average geothermal gradient at the sample locality in Cuyama Valley is approximately $35^{\circ} / \mathrm{km}$ (American Association of Petroleum Geologists, 1973), the same gradient found by Murata and Larson (1975) in the nearby Temblor Range. If the thermal conductivity of the upper phosphatic mudstone member is similar to the conductivity of the Monterey Shale in the Temblor Range, a depth of burial to which the opal-CT equilibrated can be derived. The $d(101)$ spacings between 4.123 and 4.085 angstroms in the upper phosphatic mudstone member, when compared to the findings of Murata and Larson (1975), suggest a depth of burial between $2,460 \mathrm{ft}$ $(750 \mathrm{~m})$ and $3,280 \mathrm{ft}(1 ; 000 \mathrm{~m})$.

\section{Carbonates}

Dolomite is present in 17 percent of the beds in the upper phosphatic mudstone member of the Santa Margarita Formation in trench 100 ("Stratigraphic Sections"). Individual beds (and laminae) containing dolomite consist of claystone, mudstone, siltstone, sandstone, porcellanite, and wackestone. They contain between 0.32 percent and 3.1 percent magnesium; most beds contain greater than 2.0 percent.

The occurrence of dolomite observed in thin section is often patchy; polygonal crystals are typically less than 
Table 1. X-ray characteristics $d(101)$ spacing and $2 \Theta$, of opalCT from the upper phosphatic mudstone member of the Santa Margarita Formation at trench 100 in Cuyama Valley phosphate area, Santa Barbara County, Calif.

\begin{tabular}{|c|c|c|c|c|c|}
\hline Sample No. & $\underline{\mathrm{d}}(101)$ & ${ }^{\circ} 2 \theta$ & Sample No. & $\underline{d}(101)$ & ${ }^{\circ} 2 \theta$ \\
\hline \multicolumn{3}{|c|}{ Upper sandstone member } & \multirow{2}{*}{\multicolumn{3}{|c|}{$\begin{array}{c}\text { Upper phosphatic mudstone member- } \\
\text { Continued }\end{array}$}} \\
\hline $100-1$ & - & -- & & & \\
\hline \multicolumn{3}{|c|}{ Upper phosphatic mudstone member } & \multirow{3}{*}{$\begin{array}{l}100-35 \\
100-36 \\
100-37 \\
100-38\end{array}$} & -- & -- \\
\hline $100-2$ & -- & -- & & -- & -- \\
\hline $100-2$ & $\overline{4} 114$ & $\overline{-1}$ & & 4.114 & 21.60 \\
\hline & $\begin{array}{l}4.114 \\
--\end{array}$ & $\begin{array}{c}21.60 \\
--\end{array}$ & & -- & -- \\
\hline $\begin{array}{l}100-4 \\
100-5\end{array}$ & 4.110 & $\overline{21.62}$ & $100-40$ & 4.104 & 21.65 \\
\hline \multirow{2}{*}{$100-6$} & 4.108 & $\begin{array}{l}21.62 \\
21.63\end{array}$ & $100-41$ & $\ldots$ & $\ldots$ \\
\hline & & 21.63 & $100-42$ & 4.123 & 21.55 \\
\hline $100-7$ & -- & -- & $100-43$ & 4.123 & 21.55 \\
\hline $100-8$ & 4.110 & 21.62 & $100-44$ & -- & -- \\
\hline $100-9$ & -- & - & \multirow{5}{*}{$\begin{array}{l}100-45 \\
100-46 \\
100-47 \\
100-48 \\
100-49\end{array}$} & \multirow{2}{*}{4.099} & \multirow{2}{*}{21.68} \\
\hline $100-10$ & -- & -- & & & \\
\hline $100-11$ & -- & -- & & 4.095 & $2 \overline{1.70}$ \\
\hline $100-12$ & -- & -- & & \multirow{2}{*}{$\begin{array}{l}4.099 \\
4.104\end{array}$} & \multirow{2}{*}{$\begin{array}{l}21.68 \\
21.65\end{array}$} \\
\hline $100-13$ & -- & -- & & & \\
\hline $100-14$ & 4.114 & 21.60 & $100-50$ & 4.099 & 21.68 \\
\hline $100-15$ & 4.114 & 21.60 & $100-51$ & -- & -- \\
\hline $100-16$ & -- & -- & $100-52$ & -- & -- \\
\hline \multirow{2}{*}{$\begin{array}{l}100-17 \\
100-18\end{array}$} & \multirow{2}{*}{4.116} & 21.59 & $100-53$ & 4.104 & 21.65 \\
\hline & & $\begin{array}{l}21.39 \\
--\end{array}$ & $100-54$ & -- & - \\
\hline $100-19$ & -- & -- & $100-55$ & 4.104 & 21.65 \\
\hline $100-20$ & -- & -- & $100-56$ & -- & -- \\
\hline $100-21$ & -- & -- & $100-57$ & 4.092 & 21.72 \\
\hline $100-22$ & 4.116 & 21.59 & $100-58$ & 4.104 & 21.65 \\
\hline $100-23$ & -- & 21.09 & $100-59$ & 4.114 & 21.60 \\
\hline $100-24$ & 4.123 & 21.55 & $1.00-60$ & -- & -- \\
\hline $100-25$ & 4.110 & 21.62 & $100-61$ & 4.095 & 21.70 \\
\hline $100-26$ & 4.116 & 21.59 & $100-62$ & -- & -- \\
\hline $100-27$ & 4.114 & 21.60 & $100-63$ & -- & -- \\
\hline $100-28$ & 4.116 & 21.59 & $100-64$ & 4.085 & \\
\hline $100-29$ & -- & -- & $100-65$ & 4.095 & 21.70 \\
\hline $100-30$ & 4.104 & 21.65 & $100-66$ & -- & -- \\
\hline $100-31$ & -- & - & $100-67$ & - & -- \\
\hline $100-32$ & 4.095 & 21.70 & Lower & dstone & ber \\
\hline $100-33$ & -- & -- & & & \\
\hline $\begin{array}{l}100-34 \\
100-35\end{array}$ & -- & -- & $100-68$ & -- & -- \\
\hline
\end{tabular}

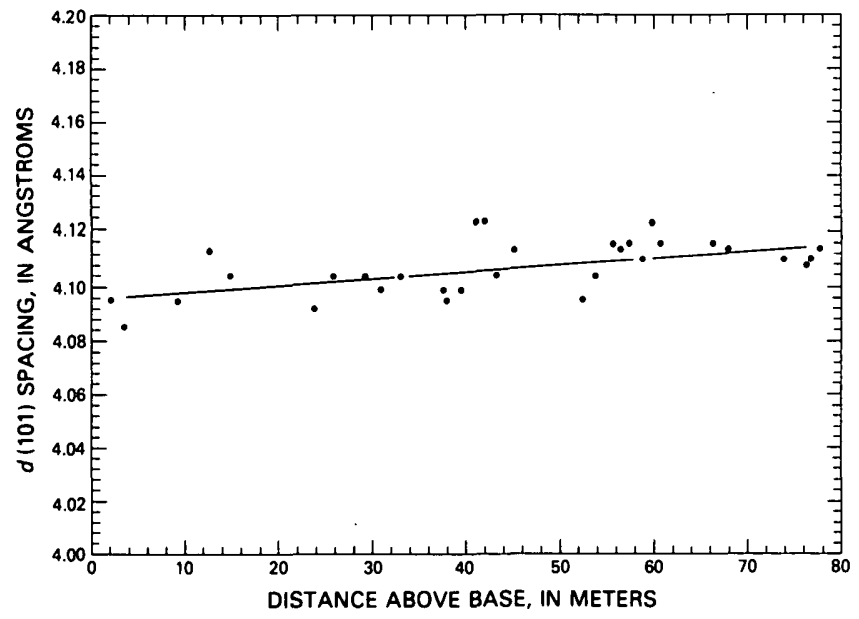

Figure 4. Diagenetic variation of opal-CT $d(101)$ spacing related to depth of burial. Samples from trench 100, in upper phosphatic mudstone member of the Santa Margarita Formation.
$0.05 \mathrm{~mm}$. In concentrated patches, the crystal mosaics have a wide range of plane intercrystalline boundaries; this type of fabric has been defined as planomural (Bathurst, 1971, p. 506). Baker and Kastner (1980) state that dolomite, common in organic-rich marine sediments, is formed by a transformation of calcite to dolomite after transformation-inhibiting $\mathrm{SO}_{4}{ }^{2-}$ and dissolved silica are removed. Sulfates are removed through their use as oxidants by anaerobic bacteria during biochemical degradation of organic matter (Demaison and Moore, 1980). The removal of silica is facilitated by the formation of opal-CT lepispheres. The presence of dolomite in the opal-CT-rich upper phosphatic mudstone member indicates that a sufficient concentration of $\mathrm{Mg}^{2}+$ remained in solution after early diagenetic alterations--concentrations in excess of that needed to convert all the calcite to dolomite (Baker and Kastner, 1980) and presumably high enough to inhibit the precipitation of carbonate fluorapatite.

Diagenetic calcite is present in very small quantities in many samples and may be part of an earlier episode of diagenesis prior to the deposition of the Santa Margarita Formation. Calcite, as observed in thin section, occurs as altered corners of clastic grains in the framework and in the nuclei of pellets.

\section{Mica and Smectite Groups}

The mica group and smectite group minerals are present in varying proportions in many samples in trench 100 . Illite and muscovite, the two mica group minerals identified in samples from trench 100 are present in many mudstone and siltstone laminae (see "Stratigraphic Sections"). Illite is by far the dominant of the two species present; muscovite, which has been identified optically, is present only as an accessory mineral in several samples.

The only member of the smectite group identified was montmorillonite. Montmorillonite is present with or without illite in many of the mudstone and siltstone laminae (see "Stratigraphic Sections"). In the bentonite beds, montmorillonite is the only clay present, and it most likely formed as an alteration product of volcanic glass. Clay separates of 12 previously determined smectite-rich samples from trench 100 were analyzed to determine whether the clays were $\mathrm{Al}^{3+}-, \mathrm{Mg}^{2+}-$, or $\mathrm{Fe}^{2+}$-rich clays. Preliminary results indicate that the smectite group minerals of selected samples from trench 100 are dominated by dioctahedral aluminumrich montmorillonite. Therefore, smectite authigenesis does not appear to provide a quantitatively great enough magnesium sink to effectively remove free magnesium from the system as a whole but may be significant in removing $\mathrm{Mg}^{2+}$ during the alteration of volcanic glass in the bentonite beds. Another possible sink for magnesium involving smectites occurs when charge deficiencies in either the octahedral or tetrahedral layer of smectites are neutralized by an isomorphous substitution of available cations. Values for the amount of $\mathrm{Mg}^{2}+$ occurring in isomorphous substitution in smectites has not been determined. 


\section{Chemical Composition}

Samples of the upper phosphatic mudstone member of the Santa Margarita Formation consist primarily of quartz, feldspars, carbonate fluorapatite, opal-CT, clay minerals, carbonate minerals, accessory minerals (including biotite, chert, chlorite, glauconite, hematite, magnetite, muscovite, sphene, and zircon), and fossil shell and bone fragments (see "Stratigraphic sections"). The results of rapid rock, semiquantitative spectrographic, and delayed-neutron activation analyses of these samples are tabulated in tables 2-12.

\section{Major Constituents}

The major elements (calculated as oxides from rapid rock analysis) in the upper phosphatic mudstone member of the Santa Margarita Formation, in order of decreasing abundance, are silicon, aluminum, calcium, phosphorus, iron, sodium, magnesium, and potassium (see table 2). The high silica content is due primarily to the high concentration of opal-CT (alteration product from diatom frustules) and detrital quartz grains. Aluminum, contained primarily in the clay minerals, is in high concentrations because of the high ratio of aluminum-rich clay minerals to detrital minerals in the upper phosphatic mudstone member. Calcium content is

Table 2. Rapid rock analyses for upper phosphatic mudstone member of the Santa Margarita Formation, at trench 296 in Cuyama Valley phosphate area, Santa Barbara County, Calif.

\begin{tabular}{|c|c|c|c|c|c|c|c|c|}
\hline $\begin{array}{l}\text { Strat. unit - } \\
\text { Field No -... } \\
\text { Sample No -.. }\end{array}$ & $\begin{array}{c}103 \\
C A-1 \\
164744\end{array}$ & $\begin{array}{c}100 \\
C A-2 \\
164745\end{array}$ & $\begin{array}{c}99 \\
C A-3 \\
164746\end{array}$ & $\begin{array}{c}94 \\
C A-5 \\
164747\end{array}$ & $\begin{array}{l}93 \\
C A-6 \\
164748\end{array}$ & $\begin{array}{c}88 \\
\text { CA-7 } \\
164749\end{array}$ & $\begin{array}{c}87 \\
C A-8 \\
164750\end{array}$ & $\begin{array}{c}86 \\
C A-9 \\
164751\end{array}$ \\
\hline $\begin{array}{l}\mathrm{SiO}_{2} \ldots \\
\mathrm{Al}_{2} \mathrm{O}_{3}-\ldots \\
\mathrm{Fe}_{2} \mathrm{O}_{3} \\
\mathrm{M}_{\mathrm{g}} \mathrm{O}_{3}\end{array}$ & $\begin{array}{c}61.3 \\
11.8 \\
2.95 \\
.9\end{array}$ & $\begin{array}{c}62.3 \\
12.8 \\
5.42 \\
1.3\end{array}$ & $\begin{array}{l}44.9 \\
8.9 \\
2.25 \\
1.8\end{array}$ & $\begin{array}{l}38.6 \\
8.1 \\
2.07 \\
1.6\end{array}$ & $\begin{array}{l}59.6 \\
10.8 \\
3.65 \\
3.1\end{array}$ & $\begin{array}{l}51.1 \\
6.7 \\
1.10 \\
6.5\end{array}$ & $\begin{array}{c}61.4 \\
12.1 \\
.73 \\
1.4\end{array}$ & $\begin{array}{l}52.8 \\
9.1 \\
1.99 \\
1.5\end{array}$ \\
\hline 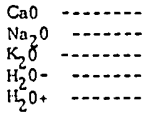 & $\begin{array}{l}6.2 \\
2.5 \\
1.9 \\
3.7 \\
2.9\end{array}$ & $\begin{array}{l}2.0 \\
1.6 \\
1.8 \\
6.3 \\
4.2\end{array}$ & $\begin{array}{r}17.6 \\
2.0 \\
1.5 \\
3.1 \\
3.2\end{array}$ & $\begin{array}{r}20.6 \\
1.7 \\
1.2 \\
3.9 \\
3.8\end{array}$ & $\begin{array}{l}4.4 \\
2.0 \\
1.8 \\
5.1 \\
3.3\end{array}$ & $\begin{array}{r}12.1 \\
1.7 \\
1.0 \\
2.3 \\
1.8\end{array}$ & $\begin{array}{l}3.3 \\
2.0 \\
1.8 \\
6.2 \\
3.8\end{array}$ & $\begin{array}{r}12.6 \\
2.0 \\
1.7 \\
4.0 \\
2.6\end{array}$ \\
\hline 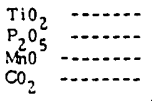 & $\begin{array}{l}.47 \\
4.5 \\
.03 \\
.25\end{array}$ & $\begin{array}{l}.67 \\
1.5 \\
.03 \\
.05\end{array}$ & $\begin{array}{l}.27 \\
8.5 \\
.03 \\
5.2\end{array}$ & $\begin{array}{c}.25 \\
14.8 \\
0 \\
1.7\end{array}$ & $\begin{array}{l}.47 \\
2.0 \\
.04 \\
2.4\end{array}$ & $\begin{array}{c}.24 \\
1.1 \\
.02 \\
14.0\end{array}$ & $\begin{array}{l}.60 \\
1.2 \\
.04 \\
.09\end{array}$ & $\begin{array}{l}.34 \\
7.7 \\
.03 \\
.70\end{array}$ \\
\hline Total & 99 & 100 & 99 & 98 & 99 & 100 & 99 & 97 \\
\hline $\begin{array}{l}\text { Strat. unit - } \\
\text { Field No } . . . \\
\text { Sample No -.. }\end{array}$ & $\begin{array}{c}85 \\
C A-10 \\
164752\end{array}$ & $\begin{array}{c}83 \\
C A-11 \\
164753\end{array}$ & $\begin{array}{c}82 \\
C A-12 \\
164754\end{array}$ & $\begin{array}{c}78 \\
C A-13 \\
164755\end{array}$ & $\begin{array}{l}77 \\
C A-14 \\
164756\end{array}$ & $\begin{array}{c}72 \\
C A-15 \\
164757\end{array}$ & $\begin{array}{c}71 \\
C A-16 \\
164758\end{array}$ & $\begin{array}{c}70 \\
C A-17 \\
164759\end{array}$ \\
\hline $\begin{array}{l}\mathrm{SiO}_{2} \ldots \ldots \\
\mathrm{Al}_{2} \mathrm{O}_{3} \\
\mathrm{Fe}_{2} \mathrm{O}_{3} \\
\mathrm{Fe} \mathrm{F}_{3} \\
\mathrm{MgO}\end{array}$ & $\begin{array}{c}64.3 \\
10.0 \\
2.6 \\
.48 \\
1.4\end{array}$ & $\begin{array}{c}34.8 \\
5.9 \\
.40 \\
.36 \\
3.0\end{array}$ & $\begin{array}{c}62.4 \\
10.8 \\
2.8 \\
.44 \\
2.2\end{array}$ & $\begin{array}{c}62.0 \\
10.1 \\
1.3 \\
.34 \\
.7\end{array}$ & $\begin{array}{l}65.8 \\
11.2 \\
2.9 \\
.38 \\
.8\end{array}$ & $\begin{array}{c}50.5 \\
8.1 \\
.73 \\
.34 \\
1.4\end{array}$ & $\begin{array}{c}65.5 \\
7.1 \\
1.5 \\
.48 \\
2.7\end{array}$ & $\begin{array}{c}57.9 \\
8.6 \\
.90 \\
.36 \\
1.5\end{array}$ \\
\hline 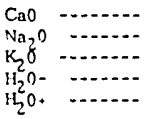 & $\begin{array}{l}5.2 \\
1.8 \\
1.7 \\
4.6 \\
3.3\end{array}$ & $\begin{array}{r}25.9 \\
1.5 \\
1.3 \\
2.2 \\
2.0\end{array}$ & $\begin{array}{l}4.5 \\
1.5 \\
1.8 \\
5.1 \\
3.7\end{array}$ & $\begin{array}{l}8.5 \\
2.0 \\
1.9 \\
3.2 \\
2.9\end{array}$ & $\begin{array}{l}3.6 \\
1.8 \\
1.9 \\
4.5 \\
3.5\end{array}$ & $\begin{array}{r}16.3 \\
2.0 \\
1.9 \\
2.4 \\
2.1\end{array}$ & $\begin{array}{l}6.7 \\
1.4 \\
1.1 \\
3.1 \\
3.0\end{array}$ & $\begin{array}{l}11.2 \\
2.4 \\
1.7 \\
2.6 \\
2.6\end{array}$ \\
\hline $\begin{array}{l}\mathrm{TiO}_{2} \\
\mathrm{P}_{2} \mathrm{O}_{5}^{2} \\
\mathrm{~N}_{4} \mathrm{H}_{5} \\
\mathrm{CO}_{2}\end{array}$ & $\begin{array}{l}.50 \\
2.1 \\
.05 \\
.93\end{array}$ & $\begin{array}{c}.20 \\
9.1 \\
.02 \\
22.8\end{array}$ & $\begin{array}{l}.54 \\
1.1 \\
.05 \\
3.1\end{array}$ & $\begin{array}{l}.31 \\
5.9 \\
.03 \\
.42\end{array}$ & $\begin{array}{l}.44 \\
2.7 \\
.04 \\
.11\end{array}$ & $\begin{array}{c}.21 \\
10.3 \\
.02 \\
2.6\end{array}$ & $\begin{array}{l}.35 \\
1.5 \\
.04 \\
4.9\end{array}$ & $\begin{array}{l}.26 \\
7.2 \\
.0 \\
1.0\end{array}$ \\
\hline Total & 39 & 93 & 100 & 100 & 100 & 99 & 99 & 98 \\
\hline
\end{tabular}

high due to its high weight percent in carbonate fluorapatite, approximately 55 percent $\mathrm{CaO}$ (Manheim and Gulbrandsen, 1979), and the presence of calcite and dolomite in much of the member. Phosphorus is low because phosphorite beds make up only a small part of the upper phosphatic mudstone member; however, the $\mathrm{P}_{2} \mathrm{O}_{5}$ content of the pellets is high. A phosphorite bed containing 80 percent pellets was selected for chemical analysis of the pellets (see table 12, trench 299, Stratigraphic Unit No. 81, Sample No. CB-1a, 1b, 1c). The pelletal fraction weighed $21.5 \mathrm{~g}$ and separated into a $15.3 \mathrm{-g}$ heavy fraction (specific gravity greater than 2.73 ), a $3.2-\mathrm{g}$ middle fraction (specific gravity of 2.68 to 2.73 ), and a $3.0-\mathrm{g}$ light fraction (specific gravity less than 2.68 ). The chemical analyses of each fraction and the weighted averages are listed in table 3 and the semiquantitative spectrographic analyses of each fraction are listed in table 4.

\section{Minor Constituents}

The minor elements in the upper phosphatic mudstone member of the Santa Margarita Formation are listed at the end of the report (see tables 5, 7-12). The analysts identified the following minor elements in concentrations above the lower limit of detection: barium, beryllium, boron, cadmium, cerium, chromium, cobalt, copper, europium, gadolinium, gallium, lanthanum, lead, manganese, molybdenum, neodymium, nickel, scandium, strontium, thorium, uranium, vanadium, ytterbium, yttrium, zinc, and zirconium.

Table 3. Average chemical composition of phosphorite pellets from trench 299, stratigraphic unit 81 , of the upper phosphatic mudstone member of the Santa Margarita Formation, Cuyama Valley phosphate area, Santa Barbara County, Calif.

\begin{tabular}{|c|c|c|c|c|}
\hline $\begin{array}{l}\text { Lab. No - } \\
\text { Sample No - } \\
\text { Specific gravity }-\end{array}$ & $\begin{array}{l}64 \mathrm{M}-1346 \\
\mathrm{CB}-1 \mathrm{a} \\
>2.73\end{array}$ & $\begin{array}{c}64 M-1347 \\
C B-1 b \\
2.68 \text { to } 2.73\end{array}$ & $\begin{array}{l}64 M-1.343 \\
C B-1 . c \\
-2.68\end{array}$ & $\begin{array}{l}\text { Welghted } \\
\text { average }\end{array}$ \\
\hline $\begin{array}{l}\mathrm{SiO}_{2} \\
\mathrm{Al}_{2} \mathrm{O}_{3} \\
\mathrm{Total}_{\mathrm{Fe}} \mathrm{Fs} \mathrm{Fe}_{2} \mathrm{O}_{3} \\
\mathrm{MgO} \mathrm{C}\end{array}$ & $\begin{array}{r}6.50 \\
1.90 \\
.89 \\
.52 \\
46.5\end{array}$ & $\begin{array}{r}7.00 \\
1.97 \\
.36 \\
.50 \\
46.5\end{array}$ & $\begin{array}{r}6.06 \\
1.87 \\
.37 \\
.51 \\
46.8\end{array}$ & $\begin{array}{r}6.51 \\
1.91 \\
.74 \\
.52 \\
46.54\end{array}$ \\
\hline $\begin{array}{l}\mathrm{Na}_{2} \mathrm{O}- \\
\mathrm{K}_{2} \mathrm{O}- \\
\mathrm{H}_{2} \mathrm{O}+\end{array}$ & $\begin{array}{r}.92 \\
.31 \\
4.06 \\
.09 \\
30.57\end{array}$ & $\begin{array}{r}1.01 \\
.32 \\
4.75 \\
.12 \\
30.18\end{array}$ & $\begin{array}{r}1.00 \\
.33 \\
4.48 \\
.06 \\
30.57\end{array}$ & $\begin{array}{r}.34 \\
.31 \\
4.22 \\
.09 \\
30.51\end{array}$ \\
\hline $\begin{array}{l}\mathrm{SrO}- \\
\mathrm{BaO}- \\
\mathrm{Br}_{2} \mathrm{O}_{3}- \\
\mathrm{MnO}- \\
\mathrm{M}-\end{array}$ & $\begin{array}{l}1.23 \\
1.03 \\
1.02 \\
1.01 \\
3.25\end{array}$ & $\begin{array}{l}1.26 \\
1.03 \\
1.02 \\
1.02 \\
3.48\end{array}$ & $\begin{array}{l}1.24 \\
1.04 \\
1.02 \\
1.01 \\
3.56\end{array}$ & $\begin{array}{l}.24 \\
.03 \\
.02 \\
.01 \\
3.33\end{array}$ \\
\hline $\mathrm{CO}_{2}-\cdots$ & 3.61 & 3.78 & 3.89 & 3.67 \\
\hline $\begin{array}{l}\text { Tota1 } \\
\text { Less } 0=\text { F }-1-\end{array}$ & $\begin{array}{r}99.41 \\
1.37\end{array}$ & $\begin{array}{r}100.30 \\
1.46\end{array}$ & $\begin{array}{r}99.81 \\
1.50\end{array}$ & 99.59 \\
\hline Subtotal & 98.04 & 98.84 & 98.31 & -- \\
\hline
\end{tabular}

${ }^{1}$ From semiquantitative spectrographic analysis by Chris Heropoulos. 
Table 4. Semiquantitative spectrographic analyses of major and minor chemical elements of phosphorite pellets from trench 299, stratigraphic unit 81, of the upper phosphatic mudstone member of the Santa Margarita Formation, Cuyama Valley phosphate area, Santa Barbara County, Calif.

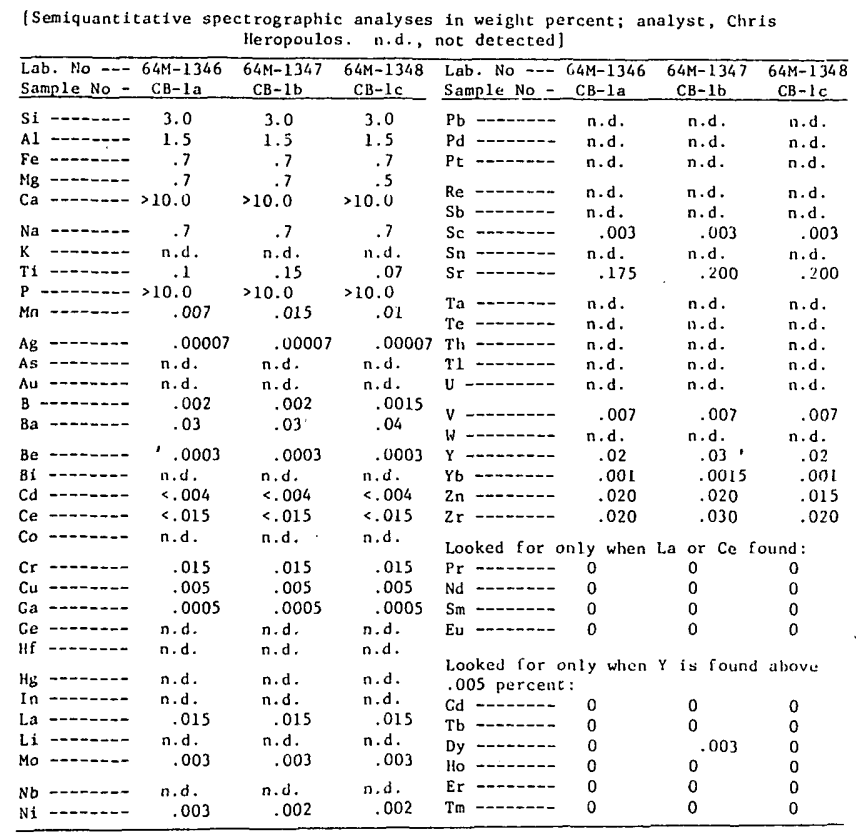

Many of the minor elements present in the upper phosphatic mudstone member were concentrated from the water column by organic and inorganic processes. The role of organisms in concentrating trace elements may have been active or passive. Trace elements such as barium, cadmium, copper, nickel, radium, and strontium were concentrated along with nutrients while the organisms were alive. Other trace elements were adsorbed or complexed to the hard and soft body parts, forming metal-organic colloids, while the dead organisms settled through the water column. Clay particles, a primary constituent of the upper phosphatic mudstone member, may have been the sequestering agent for reactive minor elements and may represent another significant source of minor elements concentrated in the sediments. The trace metal affinity for charged detrital particles may also be responsible for the limited correlation between trace elements and phosphate within individual beds of the upper phosphatic mudstone member. By whatever mechanism of concentration in the sediments and pore fluids, some of the minor elements were then adsorbed on surfaces or substituted for other ions during precipitation and growth of the carbonate fluorapatite. Strontium, thorium, uranium, and the rare earths are probably associated with the authigenic apatite of the phosphorite. The minor elements of significant concentration are: barium, cadmium, cerium, strontium, zinc, and zirconium.

\section{Barium}

Barium concentrations in the study area range from 120 to $1,200 \mathrm{ppm}$ and for 83 samples (see tables 7-12), the average concentration is $440 \mathrm{ppm}$. This value is in the 350 to $500 \mathrm{ppm}$ range for the average phosphorite that was reported by Altschuler $(1980$, p. 23$)$. Forty one of the 83 samples analyzed for barium contain greater than or equal to $500 \mathrm{ppm}$ barium, the upper limit of Altschuler's (1980) average phosphorite. The lithologies of these 41 samples are sandstone, siltstone, mudstone, phosphorite, claystone, and porcellanite; the highest concentrations of barium are found in sandstone. The concentration of barium by planktonic organisms (Martin and Knauer, 1973) and subsequent deposition within the oxygen-minimum zone may have been one source of barium for the sediments and pore fluids. However, a relatively low correlation coefficient of 0.66 between $\mathrm{Ba}$ and $\mathrm{P}_{2} \mathrm{O}_{5}$ suggests that other sources of barium were important in concentrating barium in the sediments. Substitution and adsorption may have fixed the barium in several minerals within the sediments. Evidently some of the barium was incorporated into the carbonate fluorapatite pellets (table 4).

\section{Cadmium}

Cadmium concentrations in the study area range from 42 to $180 \mathrm{ppm}$ (see tables 7-12), and for 38 samples with cadmium content above the level of detection; the average concentration is $71 \mathrm{ppm}$. This value is nearly four times larger than the $18 \mathrm{ppm}$ cadmium for the average phosphorite that was reported by Altschuler (1980, p. 24). Majmundar (1975) found as much as $625 \mathrm{ppm}$ cadmium in the phosphatic rocks in the Monterey Formation north of the La Panza Range. Cadmium concentration mimics phosphate concentration in the ocean water column as indicated by the 0.998 correlation coefficient between the two (Bruland and others, 1978). Such a high correlation suggests that cadmium, like phosphorus, is biologically fixed and concentrated by phytoplankton. The correlation coefficient between cadmium and $\mathrm{P}_{2} \mathrm{O}_{5}$ for the 38 samples, which is 0.87 , suggests that most of the cadmium is associated with carbonate fluorapatite; however, cadmium concentration in pellet separates below the detection level (table 4) indicates that cadmium is not a structural component of the carbonate fluorapatite. Perhaps the cadmium was introduced along with organic matter, and as diagenesis proceeded, it was released and adsorbed on clay minerals. The lithologies of the 38 beds from which analyzed samples contain greater than $40 \mathrm{ppm}$ cadmium are phosphorite, mudstone, fine-grained sandstone, siltstone and claystone; all but nine beds contain greater than 5 percent $\mathrm{P}_{2} \mathrm{O}_{5}$.

\section{Cerium}

Cerium concentrations in the study area range from 43 to $220 \mathrm{ppm}$, and for 83 samples (see tables 7-12), the average concentration is $115 \mathrm{ppm}$. The lithologies of the analyzed samples containing greater than $120 \mathrm{ppm}$ cerium are phos- 
phorite, siltstone, mudstone, fine-grained silty sandstone, claystone, and bentonite. The three highest concentrations (220 ppm, $200 \mathrm{ppm}$, and $190 \mathrm{ppm}$ ) were found in phosphorites and are somewhat higher than the normal abundance of cerium in marine apatite of $104 \mathrm{ppm}$ as noted by Altschuler (1980, p. 22). Two bentonite beds (trench 100, stratigraphic units 17 and 18) contained $170 \mathrm{ppm}$ of cerium; these two concentrations are among the 12 highest cerium concentrations found in the study area. The high cerium content in these two beds may be the result of high cerium content in the volcanic glass from which the bentonite altered or particle sequestering of cerium from pore fluid or sea water.

\section{Manganese}

Manganese concentrations in the study area range from 45 to $1,200 \mathrm{ppm}$, and for 83 samples (see tables 7-12), the average concentration is $280 \mathrm{ppm}$. This value is below the $1,230 \mathrm{ppm}$ manganese content for the average phosphorite that was reported by Altschuler $(1980$, p. 24$)$, however, a variation of three orders of magnitude in manganese content was observed by Altschuler (1980). These variations, according to Landing and Bruland (1980), indicate the significance of local inputs and perhaps fluxes in redox conditions in the sediment, and it is the redox conditions which ultimately control the availability of manganese for substitution or adsorption in carbonate fluorapatite and other minerals. The data in tables 3 and 4 indicate that apparently some substitution or adsorption of manganese has occurred in carbonate fluorapatite. The lithologies of the beds containing greater than $300 \mathrm{ppm}$ of manganese are mudstone, sandstone, phosphorite, siltstone, claystone, and porcellanite. The five highest concentrations of manganese occur in mudstone and very fine grained sandstone.

\section{Strontium}

Strontium concentrations in the study area range from 150 to $3,000 \mathrm{ppm}$, and for 83 samples (see tables 7-12) the average concentration is $790 \mathrm{ppm}$. This value is near the low end of the 750 to $980 \mathrm{ppm}$ range for the average phosphorite that was reported by Altschuler (1980, p. 23). Of the 83 whole rock samples analyzed, only 26 had strontium concentrations greater than $1,000 \mathrm{ppm}$. The diverse lithologies associated with this level of concentration are claystone, mudstone, siltstone, sandstone, and phosphorite. Most of these beds contain greater than 20 percent phosphatic framework; those that contain less than 20 percent phosphatic framework contain clay- or silt-size particles as a primary constituent. Pellet separates taken from a phosphorite bed (table 4) contain 0.2 weight percent of strontium; this amount is more than Altschuler's (1980) average phosphorite by a factor of 2 . A correlation coefficient of 0.86 exists between $\mathrm{Sr}$ and $\mathrm{P}_{2} \mathrm{O}_{5}$ for the 83 samples. The relatively large weight percent of strontium, high correlation coefficient between $\mathrm{Sr}$ and $\mathrm{P}_{2} \mathrm{O}_{5}$, and relatively high concentrations of strontium in plankton (Martin and Knauer, 1973) suggest that strontium was primarily derived from an active biological input rather than from passive particle sequestering and was substituted for calcium in the carbonate fluorapatite structure.

\section{Thorium}

Thorium concentration for samples from trench 100 are given in table 5. Thorium content ranges from less than 2.8 to $32.8 \mathrm{ppm}$. The highest concentrations in trench 100 are in three bentonite beds (stratigraphic unit 17 with $32.8 \mathrm{ppm}$ Th; unit 18 with $29.5 \mathrm{ppm} \mathrm{Th}$; and unit 65 with $19.3 \mathrm{ppm} \mathrm{Th}$ ). The major mineral constituent of these thorium-rich beds is montmorillonite. Claystone beds with a substantial component of montmorillonite also are relatively high in thorium. Thorium (ionic radius of $1.02 \mathrm{~A}$ ) may act chemically similar to uranium and replace calcium in the fluorapatite structure (Manheim and Gulbrandsen, 1979); however, with a correlation coefficient of 0.56 for thorium and phosphate and the high thorium concentrations in montmorillonite-rich beds, it appears that most thorium was adsorbed on the surface of clay minerals.

\section{Uranium}

Marine phosphorites from all geologic ages contain uranium, typically in the range from 50 to $300 \mathrm{ppm}$ (Cathcart, 1978). Uranium is associated with the mineral carbonate fluorapatite and is believed to be replacing calcium $\left(\mathrm{Ca}^{2+}\right.$ ionic radius of 0.99 A compared to $\mathrm{U}^{4+}$ ionic radius of 0.97 A) in the lattice or by substitution of one mole of $(\mathrm{UO} 2)^{2+}$ for two moles of $\mathrm{Ca}^{2+}$ on crystal surfaces (Altschuler and others, 1958). According to Thompson (1953), the uranium content in marine phosphate rock, although not dependent entirely on $\mathrm{P}_{2} \mathrm{O}_{5}$ content, develops the best positive correlation with phosphate in rocks with a higher average uranium content. Altschuler and others (1958) later stated that uranium concentration in marine apatite is related to the amount of reworking in the marine environment; the least amount of uranium is found in primary pellets and the most amount is found in phosphatic pebbles and nodules reworked several times. Statistical analysis of trace element content of phosphorite worldwide (Altschuler, 1980) indicates that the average marine phosphorite contains $120 \mathrm{ppm}$ uranium; the average phosphorite is enriched by a factor of 30 over the average shale ( $3.7 \mathrm{ppm}$ uranium). The $\mathrm{P}_{2} \mathrm{O}_{5}$ content of the average marine phosphorite containing $120 \mathrm{ppm}$ uranium is about 20 percent, thus, the phosphorite consists of more than 50 percent apatite and probably represents a moderate to highly reworked deposit.

The uranium content based on delayed-neutron activation analysis for whole rock samples from trench 100 are given in table 5. Uranium content ranges from $2.03 \mathrm{ppm}$ in a porcellanite to $50.9 \mathrm{ppm}$ in a pelletal phosphorite; the mean uranium content is $12.7 \mathrm{ppm}$ (standard deviation of 9.99 ppm), an order of magnitude less than Altschuler's (1980) average marine phosphorite. The average $\mathrm{P}_{2} \mathrm{O}_{5}$ content for the upper phosphatic mudstone member of the Santa Margarita 
Formation determined from trench 100 is 3.5 percent, also an order of magnitude less than the average marine phosphorite.

Applying Altschuler's (1980) average marine phosphorite for comparison to his (Altschuler and others, 1958) premise that uranium concentration is related to the amount of reworking in the marine environment, the upper phosphatic mudstone member has been subjected to only minimal amounts of reworking. Sedimentary structures in the upper phosphatic mudstone member support this hypothesis. These include laminations in many of the beds, sharp contacts between beds of different composition, and low apatite concentrations in most beds. The highest uranium concentrations are in pelletal phosphorite beds that are massive and well sorted; these characteristics suggest that the beds have been winnowed and reworked. A minimum of reworking, suggested by the uranium concentrations and sedimentary structures, may account for both the low uranium concentration and the relatively low $\mathrm{P}_{2} \mathrm{O}_{5}$ concentration for the upper phosphatic mudstone member as a whole.

Several sample populations with progressively increasing uranium concentrations were isolated and correlated with $\mathrm{P}_{2} \mathrm{O}_{5}$ concentrations to test Thompson's (1953) hypothesis relating best positive correlation between uranium and $\mathrm{P}_{2} \mathrm{O}_{5}$ with higher average uranium content. The same formula was used to derive the correlation coefficient. The correlation coefficient of $\mathrm{P}_{2} \mathrm{O}_{5}$ and uranium, based on a population of 67 samples in trench 100 , had a value of 0.95 ; this value indicates that 95 percent of the variation in uranium concentration can be explained by variation in $\mathrm{P}_{2} \mathrm{O}_{5}$ concentration. A correlation coefficient of 0.96 was obtained when samples containing greater than $10.0 \mathrm{ppm}$ uranium were used; a coefficient of 0.97 was obtained for samples with greater than $15.0 \mathrm{ppm}$ uranium and greater than 20.0 ppm uranium. Thus, the correlation of uranium with $\mathrm{P}_{2} \mathrm{O}_{5}$

Table 5. Uranium and thorium analyses of the upper phosphatic mudstone member of the Santa Margarita Formation, at trench 100 in Cuyama Valley phosphate area, Santa Barbara County, Calif.

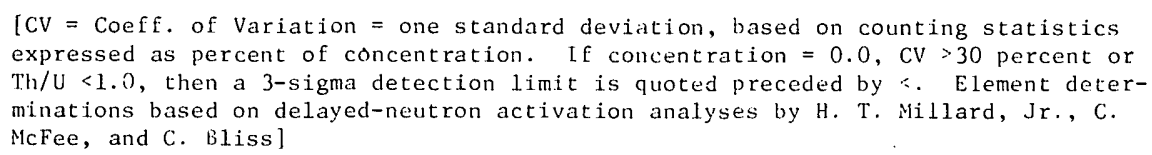

\begin{tabular}{|c|c|c|c|c|c|c|c|c|c|c|c|c|c|c|c|}
\hline Field No. & Lab No. & $\begin{array}{l}\text { Weight } \\
(\mathrm{g})\end{array}$ & $\begin{array}{l}\text { Th } \\
\text { (ppm) }\end{array}$ & $\mathrm{CV}$ & $\underset{(\mathrm{ppm})}{\mathrm{U}}$ & $\mathrm{CV}$ & Th $/ \mathrm{U}$ & Field No. & Lab No. & $\begin{array}{l}\text { We ight } \\
\text { (g) }\end{array}$ & $\begin{array}{l}\text { Th } \\
\text { (ppm) }\end{array}$ & $\mathrm{CV}$. & $\underset{\text { (ppm) }}{U}$ & $\mathrm{CV}$ & Th/U \\
\hline $100-1$ & $M-136032$ & 7.5600 & $\cdot<3.1$ & -- & 3.99 & 2 & -- & $100-36$ & M-136099 & 6.8300 & $<11.0$ & -- & 40.4 & 1 & -- \\
\hline $100-2$ & $M-136033$ & 5.1600 & 17.9 & 10 & 7.95 & 2 & 2.25 & $100-37$ & $M-136100$ & 4.2800 & $<8.6$ & -- & 18.7 & 2. & -- \\
\hline $100-3$ & $M-136034$ & 5.3700 & $<5.4$ & -- & 10.0 & 2 & -- & $100-38$ & $M-136101$ & 3.8300 & 10.0 & 19 & 5.97 & 3 & 1.67 \\
\hline $100-4$ & $M-136035$ & 4.7700 & 19.3 & 8 & 4.89 & 3 & 3.94 & $100-39$ & $M-136102$ & 5.2900 & $<8.6$ & -- & 23.4 & 2 & -- \\
\hline $100-5$ & $M-136036$ & 3.2400 & 7.9 & 28 & 7.65 & 3 & 1.04 & $100-40$ & $M-136103$ & 3.9000 & 14.0 & 16 & 8.87 & 3 & 1.53 \\
\hline $100-6$ & $M-136037$ & 3.9800 & 6.9 & 24 & 4.69 & 3 & 1.47 & $100-41$ & $M-136104$ & 5.5600 & $<6.5$ & -- & 13.9 & 2 & -- \\
\hline $100-7$ & $M-136038$ & 5.4200 & $<7.2$ & - & 17.0 & 2 & - & $100-42$ & $M-136105$ & 4.4100 & 5.4 & 24 & 2.92 & 4 & 1.89 \\
\hline $100-8$ & $M-136039$ & 3.9300 & 6.6 & -- & 9.72 & 2 & -- & $100-43$ & $M-136106$ & 4.6800 & 12.0 & 16 & 7.76 & 2 & 1.49 \\
\hline $100-9$ & $M-136040$ & 6.5100 & 16.3 & 12 & 13.4 & 2 & 1.21 & $100-44$ & $M-136107$ & 6.0300 & $<13.0$ & -- & 50.9 & 1 & -- \\
\hline $100-10$ & $M-136041$ & 5.0600 & 15.7 & 12 & 8.50 & 2 & 1.85 & $100-45$ & $M-136108$ & 3.9400 & 7.7 & 23 & 5.27 & 3 & 1.47 \\
\hline $100-11$ & $M-136042$ & 4.1600 & 15.2 & 12 & 5.89 & 3 & 2.59 & $100-46$ & M-136109 & 6.5600 & 13.9 & 14 & 12.7 & 2 & 1.10 \\
\hline $100-12$ & $M-136043$ & 5.9800 & $<6.8$ & -- & 16.8 & 2 & -- & $100-47$ & M-136110 & 4.4500 & 8.2 & - & 17.9 & 2 & -- \\
\hline $100-13$ & $M-136044$ & 6.1600 & $<8.7$ & -- & 27.4 & 1 & -- & $100-48$ & $M-136111$ & 5.3500 & 11.7 & 13 & 4.92 & 3 & 2.37 \\
\hline $100-14$ & $M-136045$ & 3.9100 & 16.0 & 15 & 12.9 & 2 & 1.28 & $100-49$ & $M-136112$ & 4.5200 & 12.0 & 16 & 7.16 & 3 & 1.62 \\
\hline $100-15$ & $M-136046$ & 4.3400 & 16.0 & 16 & 13.9 & 2 & 1.13 & $100-50$ & $M-136113$ & 4.9900 & 9.6 & - & 27.4 & 2 & -- \\
\hline $100-16$ & $M-136047$ & 6.4500 & $<9.9$ & -- & 35.6 & 1 & -- & $100-51$ & $M-136114$ & 4.7500 & 29.5 & 7 & 7.13 & 2 & 4.14 \\
\hline $100-17$ & $M-136048$ & 4.3500 & 17.0 & 12 & 8.06 & 2 & 2.10 & $100-52$ & $M-136115$ & 5.1600 & 32.8 & 6 & 7.15 & 2 & 4.59 \\
\hline $100-18$ & $M-136049$ & 6.8500 & $<7.7$ & -- & 24.7 & 1 & -- & $100-53$ & M-136116 & 5.5800 & 4.5 & -- & 5.85 & 2 & -- \\
\hline $100-19$ & $M-136050$ & 5.1300 & 8.9 & 18 & 6.20 & 3 & 1.43 & $100-54$ & M-136117 & 7.0700 & 4.6 & - & 8.68 & 2 & -- \\
\hline $100-20$ & $M-136051$ & 5.0800 & $<8.7$ & -- & 23.7 & 2 & -- & $100-55$ & $M-136118$ & 5.6100 & $11.0^{\prime}$ & 16 & 8.84 & 2 & 1.27 \\
\hline $100-21$ & $M-136052$ & 5.7200 & $<10.0$ & -- & 35.8 & 1 & -- & $100-56$ & $M-136119$ & 5.4300 & 16.2 & 9 & 4.72 & 3 & 3.44 \\
\hline $100-22$ & $M-136053$ & 4.3800 & $<6.9$ & -- & 13.7 & 2 & -- & $100-57$ & $M-136120$ & 5.4600 & 11.0 & 17 & 9.02 & 2 & 1.22 \\
\hline $100-23$ & $M-136054$ & 5.6300 & $<8.3$ & -- & 24.8 & 1 & -- & $100-58$ & $M-136121$ & 4.4500 & 7.3 & 23 & 5.87 & 3 & 1.24 \\
\hline $100-24$ & $M-136055$ & 5.5900 & $<2.8$ & -- & 2.03 & 4 & -- & $100-59$ & $M-136122$ & 5.2500 & 12.2 & 14 & 7.26 & 2 & 1.68 \\
\hline $100-25$ & $M-136056$ & 4.1800 & 10.5 & 15 & 4.15 & 3 & 2.52 & $100-60$ & $M-136123$ & 7.9800 & 4.7 & -- & 10.5 & 2 & -- \\
\hline $100-26$ & M-136057 & 4.6000 & $<7.5$ & -- & 16.6 & 2 & -- & $100-61$ & $M-136124$ & 5.2300 & 8.3 & 16 & 3.92 & 3 & 2.10 \\
\hline $100-27$ & $M-136058$ & 4.7800 & $<6.1$ & -- & 11.2 & 2 & -- & $100-62$ & $M-136125$ & 7.2900 & 5.9 & -- & 15.3 & 1 & -- \\
\hline $100-28$ & $M-136059$ & 4.0400 & 13.0 & 16 & 8.95 & 2 & 1.47 & $100-63$ & $M-136126$ & 6.1100 & 6.0 & 20 & 3.11 & 3 & 1.92 \\
\hline $100-29$ & $M-136060$ & 5.8400 & $<7.1$ & -- & 18.9 & 2 & -- & $100-64$ & M-136127 & 4.8900 & 19.0 & 8 & 4.04 & 3 & 4.70 \\
\hline $100-30$ & $M-136061$ & 3.5800 & $<4.8$ & -- & 3.99 & 4 & -- & $100-65$ & $M-136128$ & 6.3000 & 8.9 & 15 & 5.26 & 2 & 1.69 \\
\hline $100-31$ & $M-136062$ & 5.0900 & $<7.8$ & -- & 19.5 & 2 & -- & $100-66$ & M-136129 & 6.0000 & 18.5 & 10 & 10.5 & 2 & 1.76 \\
\hline $100-32$ & $M-136063$ & 3.7500 & 9.2 & 21 & 6.51 & 3 & 1.41 & $100-67$ & $M-136130$ & 7.0700 & 8.30 & 13 & 3.63 & 3 & 2.28 \\
\hline $100-33$ & $M-136064$ & 4.9600 & $<10.0$ & -- & 32.8 & 1 & -- & & & & & & & & \\
\hline $100-34$ & $M-136065$ & 4.7500 & 18.4 & 12 & 11.1 & 2 & 1.66 & & & & & & & & \\
\hline $100-35$ & $M-136098$ & 5.0500 & 15.5 & 14 & 11.0 & 2 & 1.41 & & & & & & & & \\
\hline
\end{tabular}


does show an increase in positive correlation with higher average uranium content as suggested by Thompson (1953). What is intriguing is the large discrepancy between the results of Thompson's work $(1953 ; 1954)$ on phosphatic rocks with uranium concentrations similar to those in the study area and the results from the study area. At uranium concentrations less than $100 \mathrm{ppm}$, comparable to uranium concentrations in the study area, Thompson $(1953$; 1954) found almost no meaningful correlation between phosphate and uranium. However, in the study area, where concentrations are no greater than $50.9 \mathrm{ppm}$, very high correlations between uranium and phosphate concentrations were found.

\section{Zinc}

Zinc concentrations in the study area range from 16 to $220 \mathrm{ppm}$, and for 81 samples (see tables 7-12), the average concentration is $83 \mathrm{ppm}$. This value bears a closer resemblance to the zinc content of average shale (95 ppm) than to the zinc content of average phosphorite (195 ppm) as reported by Altschuler (1980, p. 24). The average zinc content for beds lithologically classified as phosphorite is $160 \mathrm{ppm}$, also below Altschuler's (1980) average. Nonetheless, there is good correlation between zinc and phosphate concentration in the 81 analyzed samples; the correlation coefficient for $\mathrm{Zn}$ and $\mathrm{P}_{2} \mathrm{O}_{5}$ is 0.91 . Zinc concentrations in the water column exhibit strong correlation with the nutrient silica (correlation coefficient of 0.996 ) suggesting that zinc is concentrated by active biologic processes in surface waters and transported to the bottom as biogenic particles (Bruland, 1980). The high correlation coefficient between zinc and phosphate in the 81 samples from the upper phosphatic mudstone member of the Santa Margarita Formation suggests that zinc may be incorporated in the carbonate fluorapatite. The results of the semiquantitative analysis of pellet separates (table 4) confirm the supposition that the concentration of zinc may be attributed to substitution of zinc for calcium or surface adsorption in carbonate fluorapatite. Supporting evidence is provided by the highest zinc concentrations being found in phosphorite beds. The lithologies of other beds containing greater than $100 \mathrm{ppm}$ zinc are: mudstone, sandstone, siltstone, and claystone, all of which contain greater than 5.0 percent $\mathrm{P}_{2} \mathrm{O}_{5}, 80$ percent of which contain greater than 7.0 percent $\mathrm{P}_{2} \mathrm{O}_{5}$.

\section{Zirconium}

Zirconium concentrations in the study area range from 12 to $620 \mathrm{ppm}$, and for 83 samples (see tables 7-12), the average concentration is $71 \mathrm{ppm}$. In the reference section of trench 100, the lithologic units in the lower part of the upper phosphatic mudstone member of the Santa Margarita Formation had much higher concentrations of zirconium than the units in the upper part, particularly stratigraphic units 18 down to basal unit 1 . Porcellanite in the upper part of the member contained the least amount, that is, $12 \mathrm{ppm}$ in stratigraphic unit $45,44 \mathrm{ppm}$ in stratigraphic unit 39; and bentonite and bentonitic siltstone in the lower part of the member contained the most, that is, $620 \mathrm{ppm}$ in stratigraphic unit $18,540 \mathrm{ppm}$ in stratigraphic unit 17, and $330 \mathrm{ppm}$ in stratigraphic unit 13 . Zirconium concentrations as high as these in the bentonite beds require peralkaline volcanic ash as a source (Ferrara and Treuil, 1975); the zirconium is attributed to the accessory mineral zircon derived from that ash. The Timber Mountain caldera complex, in south west Nevada, was a major peralkaline volcanic center during the late Miocene and may have been the source area for the ash derived bentonite beds.

\section{Geochemical Ratios}

The thorium-uranium ratio for individual beds is also given in table 5 . The mean of the reported ratios is 2.00 and the standard deviation is 0.97 ; these values are approximately midway between the values for shale (3.2) and average marine phosphorite $(0.055-0.07)$ reported by Altschuler (1980).

The mean zinc-cadmium ratio was determined for whole-rock samples with cadmium concentrations above the minimum level of detection. The mean zinc-cadmium ratio is 1.85 , an order of magnitude less than the ratio for the average marine phosphorite (10.0) and two orders of magnitude less than the ratio for shale $(300.0)$ as reported by Altschuler (1980, p. 26).

The average yttrium-lanthanum ratio for carbonate fluorapatite in the upper phosphatic mudstone member is based on three pellet separates from trench 299 (table 4). The ratio is 1.6, very similar to the 1.8 ratio of $Y: L a$ from concentrated apatite for the average phosphorite (Altschuler, 1980, p. 26).

The average cerium-lanthanum ratio in carbonate fluorapatite is not derived because the cerium content in pellet separates is below the level of detection (see table 4). The cerium-lanthanum ratio, determined from whole-rock samples from trench 100 (see table 7), is 2.16 . This value is the same within analytical error as the 2.1 cerium-lanthanum ratio for the average shale reported by Altschuler (1980).

\section{PHOSPHATIC SETTING}

Phosphogenesis is a controversial concept because the evidence from the variety of rock types and environments which contain phosphate is inconclusive. Many hypotheses have been developed to explain geographic or laboratory observations. Some of the hypotheses that are pertinent to the Cuyama Valley phosphate deposit are included in Gulbrandsen (1969), Baturin (197lb), Manheim and others (1975), Manheim and Gulbrandsen (1979), Price and Calvert (1978), Riggs (1979), Burnett and others (1980), and Sheldon (1981). Changes in the physicochemical conditions during and after deposition of phosphatic material affect the stability and solubility of the material, and therefore the occurrence of phosphate-bearing rocks. These conditions may include changes in: sea level, oceanic circulation patterns, depth of 
impingement of the oxygen-minimum zone on the shelf and slope, rates of surface biological productivity, rates of sedimentation, concentration of various elements and ions, and $\mathrm{pH}, \mathrm{Eh}$, and alkalinity of the pore fluids. Detailed petrographic, SEM and EDAX, $\mathrm{X}$-ray diffraction, and chemical investigations allow the authors to model the phosphogenic-diagenetic processes that led to the development of the Cuyama Valley phosphate deposits.

\section{Depositional Environment}

Depositional structures and faunal assemblages of the sandstone and mudstone members of the Santa Margarita Formation provide criteria for paleoenvironmental interpretation. The better preserved and more distinctive structures and faunas in the resistant sandstone members contribute to our understanding of the less resistant and often bioturbated but sparsely fossiliferous mudstone members. Because observations for depositional analysis of the upper phosphatic mudstone member are essentially limited to exposures in trenches, a detailed environmental assignment is impossible. However, using the sedimentary and faunal data for the closely related sandstone members in support of the trench information, a reasonable interpretation of the depositional environment of the upper phosphatic mudstone member was made.

Asymmetric ripple depositional structures, as well as the faunas in the sandstone members, suggest that the sandstone members were deposited at shallow depths, 0-200 ft $(0-60 \mathrm{~m})$, adjacent to a marine shoreline in an area designated the inner offshore facies by Clifton and others (1971, p. 659). This environment extends to the depth limit of sand deposition or to where mud deposition starts. Many variables control this depth limit, thus precluding a firm bathymetric range for correlation. However, using the Continental Borderland of southern California as a recent model for the late Miocene depositional environment of the Cuyama Valley study area, the sand-mud boundary ranges from about $60 \mathrm{ft}(18 \mathrm{~m})$ to 200 $\mathrm{ft}(60 \mathrm{~m})$ as interpreted from Welday and Williams (1975). The sandstone members consist of fine- to medium-grained sandstone beds with less than 20 percent interbedded mudstone and lenses of pebble conglomerate. Most of the sandstone units are unstratified as a result of bioturbation, thus most beds are structureless. Internal structure for the few nonbioturbated sandstone beds is gently inclined cross-stratification.

Depositional arrangement of bedding, grain-size distribution, lithology, and paleoecology of the phosphatic mudstone members suggests that the mudstone members were deposited seaward on the offshore shelf in deeper water adjacent to the sandstone members. The interbedding of sandstone and mudstone units throughout the offshore Santa Margarita sequence may be attributed to transgressiveregressive cyclic deposition relative to tectonic activity along the northern margin of the basin (Clifton, 1981). The phos- phatic members consist of mudstone, claystone, and siltstone with less than 20 percent sandstone (see "Stratigraphic Sections", trench 100). Phosphatic pellets and nodules in the mudstone are common and phosphate in the matrix is common. Many of the beds at the base are graded with nodules, fish and mammal bones, and shell fragments. Often the base is a sharp irregular contact with the underlying unit. Most beds are massive, occasionally vaguely bedded, suggesting bioturbation. Burrows filled with pellets or sand grains also suggest bioturbation. The megafaunal population is considerably less in the phosphatic mudstone members than in the sandstone members; this suggests reducing or low oxygen conditions at the mudstone depositional site. Diatoms are common in the mudstone members, and dissolution of the more soluble species during diagenesis has added an increasing amount of siliceous cement.

\section{Phosphogenesis}

Petrographic and SEM investigations of the upper phosphatic mudstone member of the Santa Margarita Formation suggest multiple, intermittent stages of the development or formation of apatite pellets. Phosphatic framework components include: phosphatized diatoms (pl. 6, $A, B, C$ ), pellets with noncentered clastic inclusions, structureless pellets, pellets with diatom frustule inclusions (pl. 6, D, F), phosphatized mollusk(?) and other shell fragments, fish bones (pl. 6, $E$ ), pellets with centered clastic inclusions (pl. 6, $G$ ), phosphatic ooliths (pl. 6, $H$ ), compound pellets (pl. $6, I, K$ ), phosphatic intraclasts (pl. 6, $L, M$ ), and apatite matrix. Perhaps the first in a series of stages was the development of some of the apatite pellets. A subsequent stage may have been the accretionary phosphatic growth or alteration of some preexisting material to iron oxides; this change indicates a changed environment. Either complete replacement of a pellet by ferruginous material or the formation of a concentric ferruginous band ( $\mathrm{pl} .6, J$ ) around the pellet resulted. The limited occurrence of this type of pellet indicates that it was a temporally restricted phenomenon, perhaps occurring in the shallow subsurface when fluctuating redox conditions prevailed. Petrographic evidence in the form of multiple colored bands of apatite (pl. 6,I) suggests that these two stages may have been repeated by environmental fluctuations. The development of apatite pellets occurred contemporaneously with the phosphatic replacement of calcareous shell fragments and diatom frustules (pl. 6, C). The replacement of shell fragments resulted in the obliteration of all internal microstructure, thereby rendering identification of the shells impossible. In some rocks, during a late stage of growth, apatite accreted on individual pellets and formed concentric phosphatic bands (pl. 6, $F, G$ ) or incased groups of pellets and thereby formed compound pellets (pl. $6, I, K$ ). The late stage may be distinguished from earlier stages by textural relationships such as different crystal size, lower transparency, differing amounts of inclusions, and a darker brown color. The inclusions and darker color may be due to contamination 
of the phosphate by organic matter (R. A. Gulbrandsen, oral commun., 1980).

The phosphatic components of the Santa Margarita Formation may have originated in a variety of ways including: precipitation below the sediment water interface, formation at the sediment water interface, replacement of fecal pellets, and replacement of calcareous material. Formation of the apatite may have taken place below the sediment water interface within interstitial pore spaces where pore fluids were supersaturated with respect to amorphous calcium phosphate (Baturin, 1978). These conditions have been observed in the pore fluids of shallow water fine-grained and diatomaceous sediments that are high in dissolved phosphorus (Baturin, 1972; Brooks and others, 1968). Under such conditions phosphate precipitation may nucleate on diatom frustules (pl. 6 , A, B), carbonate detritus, fish bones (pl. 6,E), and clastic grains (pl. 6, G, $H, I, K$ ) (Baturin, 1978). Structureless pellets with indistinct boundaries that seem to grade into the mudstone matrix suggest in situ formation of pellets. Baturin (1978) stated that phosphate gels precipitated from pore water may differ from the surrounding sediment only in the $\mathrm{P}_{2} \mathrm{O}_{5}$ content; a self-purging of nonphosphatic components can increase the $\mathrm{P}_{2} \mathrm{O}_{5}$ content during subsequent diagenesis thus forming phosphatic grains and pellets. Fecal pellets from burrowing organisms was suggested as a possible origin for some pellets (Baturin, 1978). The formation of phosphatic ooliths (pl. $6, H$ ), if they originated by a similar process as carbonate ooliths, require movement and formed at the sediment-water interface in a zone of agitation.

Several sedimentary features present in the upper phosphatic mudstone member of the Santa Margarita Formation suggest that reworking and subsequent concentration of phosphatic sediments were an integral part of phosphogenesis. These processes may, in part, account for the low variance in the size of the pellets (pl. $6, N)$. Subrounded phosphatic intraclasts and nodules with a matrix different from the rock matrix indicate physical reworking and transport from a previous site of deposition. Ooliths, if formed in an agitated environment, were transported from a high energy nearshore environment to a low energy offshore mud facies (upper phosphatic mudstone member). Phosphatic framework material, primarily pellets, is often concentrated in burrows, laminae, and lenses in a generally pellet-poor or pellet-free rock. In pellet-supported laminae of phosphatic siltstone, mudstone, and sandstone, as well as phosphorite, pellet size variability is low (pl. $6, N$ ) with diameters ranging from 0.15 to $0.25 \mathrm{~mm}$. Pellets of uniform size should have similar hydraulic equivalents and respond comparably under similar hydraulic conditions. Current and tidal velocities, as well as storm wave orbital motion and wave action during lower stands in sea level, may have been strong enough to winnow the lighter and smaller size material away and subsequently concentrate the pellets with a minimum of transport. Clastic grains commonly protrude from the edges of phosphatic pellets; such a texture could not form or remain if the pellets were subject to transport over a great distance because the grains would likely be torn from the pellets (Cook, 1967). The protruding grain-surface texture in pellet-supported laminae would probably be preserved if the pellets were concentrated by winnowing rather than by transport. Other support for this premise is the general lack of clastic material with presumably similar hydraulic equivalents in pellet-supported laminae and lenses. No evidence in the internal structure of these pellets was found to indicate an authigenic origin for these clastic grains.

\section{Model for the Santa Margarita Formation}

The exact processes that led to the formation of the upper phosphatic mudstone member of the Santa Margarita Formation in the study area are obscure. The model presented here is a modification of the five step model of Baturin (1978, p. 181). It consists of biogenic-diagenetic processes of phosphate formation in fine-grained sediments, and subsequent reworking of the sediments to concentrate the apatite pellets. The model does not attempt to explain all the sedimentological features present in the phosphatic mudstone members of the Santa Margarita Formation, nor is the process of phosphogenesis as simple as presented in the model-the available data is merely incorporated and assimilated in a workable model.

The paleogeographic reconstruction (Addicott, 1968; Lagoe, 1984), the fossil evidence (Fritsche, 1969; Vedder and Repenning, 1975), and the sedimentological features (Clifton, 1981) suggest that the Cuyama Valley site of deposition of the Santa Margarita Formation was a subtropical shelf environment along a western continental margin. Upwelling currents typically associated with these geographic locations provided the necessary supply of phosphorus and other nutrients to support a high rate of biological productivity in the water column above the shelf. Upon the death and decomposition of the diatoms and other phytoplankton, the phosphorus is returned to the seawater or deposited in the organicmatter detritus (Ketchum and Redfield, 1949); this process provided a means of transporting phosphorus to the sediment. High surface productivity combined with expansion of the oxygen-minimum zone onto the shelf during the Neogene polytaxic episode (Fischer and Arthur, 1977) led to an oxygen-deficient bottom environment. A state of suboxia in the water column may have existed because of an insufficient supply of free oxygen to meet the biochemical oxygen demand (Demaison and Moore, 1980). The suboxic conditions enhanced the accumulation of decomposed organicand phosphorus-rich diatomaceous sediment. Highly mobile organic phosphorus (Baturin, 1978) accumulated in the interstitial fluids until the fluids became supersaturated with respect to a calcium phosphate solid phase, possibly an amorphous phase. Precipitation of the calcium phosphate began at acceptable nucleation sites and continued until the pore fluids were no longer supersaturated. 
Alternation of sandstone members with mudstone members of the Santa Margarita Formation in the Cuyama Valley indicates a cyclic pattern of minor regressions and transgressions during the Mohnian Stage of the Miocene. Vail and others (1977) identified very similar fluctuations in sea level on a global scale during the late Miocene. Hydrologically quiet conditions necessary for the accumulation of fine-grained biogenic sediments (Baturin, 1978) existed during the transgressive episodes of the Mohnian Stage. Both argillaceous members of the Santa Margarita Formation are phosphatic. The upper member is thicker than the lower member, $275 \mathrm{ft}(85 \mathrm{~m})$ thick and $150 \mathrm{ft}(45 \mathrm{~m})$ thick, respectively; this difference in thickness suggests a longer transgressive episode in the upper member than in the lower member if deposition occurred at equal rates, and a longer period for the accumulation of calcium phosphate (later converted to apatite) in the sediments of the upper member than in the lower member. Phosphatic components were then concentrated in some beds by the process of winnowing and reworking of the sediments in response to wave and current action. Laterally persistent beds of well-segregated relatively coarse material, in this case mainly pellets in a mudstone matrix, are characteristic of sediments that have been winnowed and reworked by waves (Clifton, 1973).

At some time after the precipitation of amorphous calcium phosphate, diagenetic removal of the crystalline phase inhibiting $\mathrm{Mg}^{2+}$ was sufficient to begin the kinetic reaction between amorphous calcium phosphate and crystalline carbonate fluorapatite in the direction of the crystalline phase. Alternatively, sufficient time elapsed such that the inhibiting effects of $\mathrm{Mg}^{2+}$ no longer influenced the kinetic reaction and the phase change proceeded in the presence of magnesium ions. The end result was the formation of the carbonate fluorapatite now found at the Cuyama Valley phosphate site.

\section{PHOSPHATE RESOURCES OF THE UPPER PHOSPHATIC MUDSTONE MEMBER OF THE SANTA MARGARITA FORMATION}

Phosphate resources at the Cuyama Valley site were calculated for phosphatic rock containing a weighted average greater than 8.0 percent $\mathrm{P}_{2} \mathrm{O}_{5}$ and greater than 5.0 percent $\mathrm{P}_{2} \mathrm{O}_{5}$ (Fedewa and Hovland, 1981). The minimum thickness of phosphatic beds used in determining phosphate resource zones was $1 \mathrm{ft}(0.3 \mathrm{~m})$ (fig. 5 , table 6$)$ and the beds had less than $600 \mathrm{ft}(183 \mathrm{~m})$ of overburden (pl. 3). A total of 138.58 million short tons (125.98 million metric tons) greater than 8.0 percent $\mathrm{P}_{2} \mathrm{O}_{5}$ phosphate rock and 404.33 million short tons (367.57 million metric tons) of greater than 5.0 percent

Figure 5. The ore zones used in tonnage estimates of the phosphate in the upper phosphatic mudstone member of the Santa Margarita Formation.

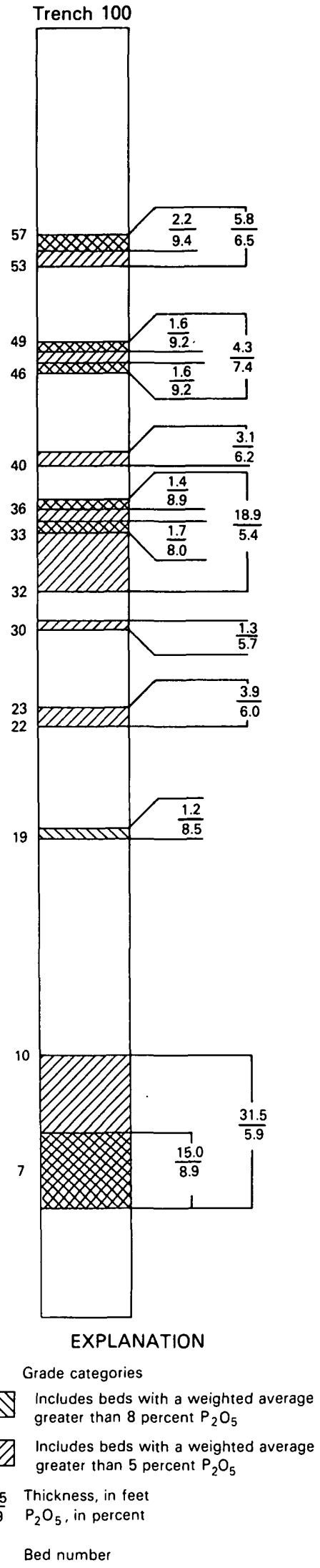


$\mathrm{P}_{2} \mathrm{O}_{5}$ phosphatic rock were calculated for the upper phosphatic mudstone member of the Santa Margarita Formation in the Cuyama Valley phosphate area (table 6).

Table 6. Inferred phosphate resources in the upper phosphatic mudstone member of the Santa Margarita Formation, Cuyama Valley phosphate area, Santa Barbara County, Calif.

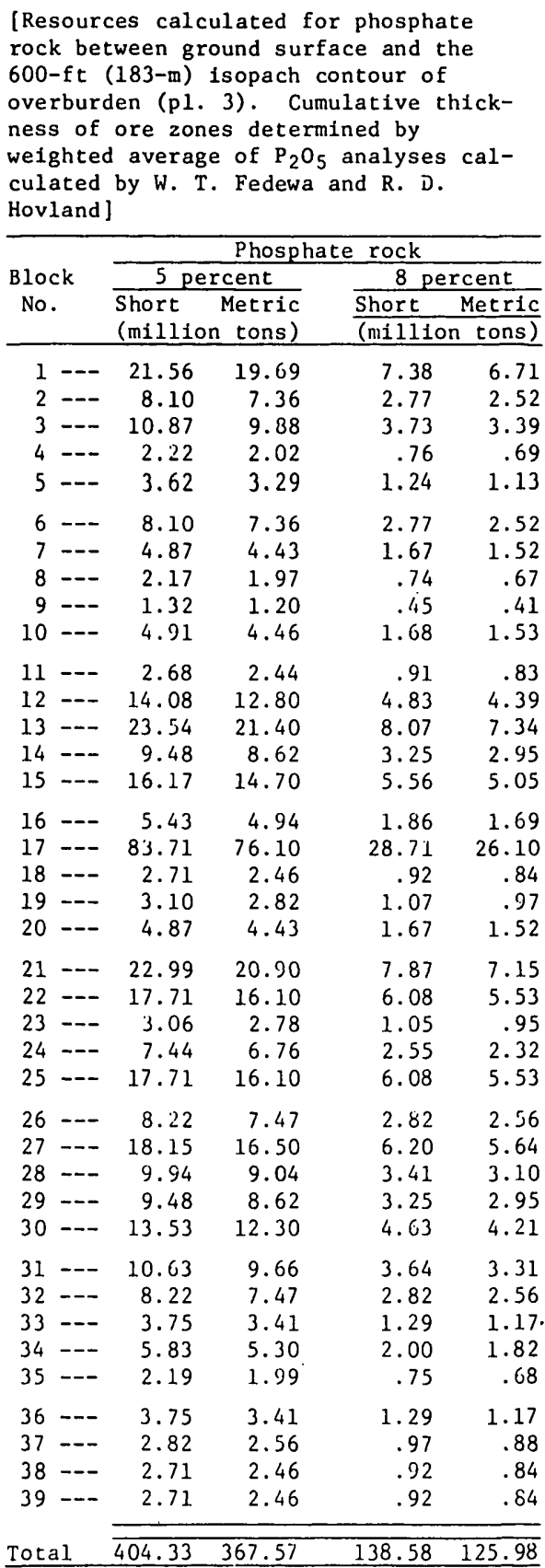

\section{REFERENCES CITED}

Addicott, W. O., 1968, Mid-Tertiary zoogeographic and paleogeographic discontinuities across the San Andreas fault, California, in Dickinson, W. R., and Grantz, A. A., eds., Proceedings of conference on geologic problems of San Andreas fault system: Stanford University Publications, Geological Sciences, v. 11, p. 144-165.

Altschuler, Z. S., 1980, The geochemistry of trace elements in marine phosphorites - Part 1. Characteristic abundances and enrichment, in Bentor, Y. K., ed., Marine phosphorites-geochemistry, occurrence, genesis: Society of Economic Paleontologists and Mineralogists Special Publication, no. 29, 249 p.

Altschuler, Z. S., Clarke, R. S., Jr., and Young, E. J., 1958, Geochemistry of uranium in apatite and phosphorite: U.S. Geological Survey Professional Paper 314-D, p. D45-D90.

American Association of Petroleum Geologists, 1973, Geothermal Survey of North America-Geothermal Gradient of Southern California: American Association Petroleum Geologists, Portfolio Map Area 22, scale 1:1,000,000.

Antisell, T., 1856, Geological report [Parke's surveys in California and near thirty-second parallel]: U. S. Pacific Railroad Explorations (U.S. 33d Congress, 2d session, S. Ex. Document 78, H. Ex. Document 91), v. 7, pt. 2, 204 p.

Atwater, T., 1970, Implications of plate tectonics for the Cenozoic tectonics of western North America: Geological Society of America Bulletin, v. 81, no. 12, p. 3513-3536.

Baker, P. A., and Kastner, M., 1980, The origin of dolomite in marine sediments [abs.]: Geological Society of America Abstracts with Programs, 1980 Annual Meeting, v. 12, no. 7, p. 381.

Bartow, J. A., 1978, Oligocene continental sedimentation in the Caliente Range area, California: Journal of Sedimentary Petrology, v. 48 , no. 1, p. 75-98.

Bathurst, R. G. C., 1971, Carbonate sediments and their diagenesis (2nd ed.), in Developments in Sedimentology, Volume 12: Amsterdam, Elsevier, 658 p.

Baturin, G. N., 1969, Authigenic phosphate concretions in Recent sediments of the southwest African shelf: Oceanography, v. 189 , no. 6, p. 227-230.

1971a, Stages of phosphorite formation on the ocean floor: Nature, Physical Science, v. 232, no. 29, p. 61-62.

$-197 \mathrm{lb}$, Formation of phosphate sediments and water dynamics: Oceanology, v. 11, no. 3, p. 372-376.

1972, Phosphorus in interstitial waters of sediments of the Southeastern Atlantic: Oceanology, v. 12, no. 6, p. 849-855 [English language edition of Okeanologiya].

1978, Phosphorites: P. P. Shirshow Institute of Oceanology, Academy of Sciences of the U.S.S.R., Nauka Press, Moscow, $232 \mathrm{pp}$. [English translation].

Baturin, G. N., Merkulova, K. I., and Chalov, P. I., 1972, Radiometric evidence for Recent formation of phosphatic nodules in marine shelf sediments: Marine Geology, v. 13, no. 3, p. M37-M41.

Bischoff, J. L., and $\mathrm{Ku}$, T., 1970, Pore fluids of recent marine sediments: I., Oxidizing sediments of $20^{\circ} \mathrm{N}$, , continental rise to Mid-Atlantic Ridge: Journal of Sedimentary Petrology, $v$. 40, no. 3, p. 960-972.

Bischoff, J. L., and Sayles, F. L., 1972, Pore fluid and mineralogical 
studies of recent marine sediments: Bauer Depression Region of East Pacific Rise: Journal of Sedimentary Petrology, v. 42, no. 3, p. 711-724.

Blake, M. C., Jr., Campbell, R. H., Dibblee, T. W., Jr., Howell, D. G., Nilsen, T. H., Normark, W. R., Vedder, J. G., and Silver, E. A., 1978, Neogene basin formation in relation to platetectonic evolution of San Andreas fault system, California: American Association of Petroleum Geologists Bulletin, v. 62, no. 3 , p. $344-372$.

Booth, J. S., 1974, Early diagenesis in Southern California Continental Borderland sediments: Los Angeles, Calif., University of Southern California, Ph.D. dissertation, $175 \mathrm{p}$.

Bramlette, M. N., 1946, The Monterey Formation of California and the origin of its siliceous rocks: U. S. Geological Survey Professional Paper 212, 57 p.

Brooks, R. R., Presley, B. J., Kaplan, I. R., 1968, Trace elements in the interstitial waters of marine sediments: Geochimica et Cosmochimica Acta, v. 32 , no. 4, p. 397-414.

Bruland, K. W., 1980, Oceanographic distributions of cadmium, zinc, nickel, and copper in the north Pacific: Earth and Planetary Science Letters, v. 47, p. 176-198.

Bruland, K. W., Knauer, G. A., and Martin, J. H., 1978, Cadmium in northeast Pacific waters: Limnology and Oceanography, $v$. 123 , no. 4 , p. $618-625$.

Burnett, W. C., 1974, Phosphorite deposits from the sea floor off Peru and Chile-radiochemical and geochemical investigations concerning their origin: Hawaii Institute of Geophysics Report, HIG-74-3, 164 p.

Burnett, W. C., Veeh, H. H., and Soutar, A., 1980, U-series, oceanographic, and sedimentary evidence in support of Recent formation of phosphate nodules off Peru: Society of Economic Paleontologists and Mineralogists Special Publication no. 29, p. 61-71.

Carroll, D., 1970, Clay minerals: a guide to their X-ray identification: Geological Society of America Special Paper 126, 80 p.

Cathcart, J. B., 1978, Uranium in phosphate rock: U.S. Geological Survey Professional Paper 988-A, p. Al-A6.

Champion, D. E., Gromme, C. S., and Howell, D. G., 1980, Paleomagnetism of the Cretaceous Pigeon Point Formation and the inferred northward displacement of $2500 \mathrm{~km}$ for the Salinian block, California [abs.]: American Geophysical Union Transactions, v. 61 , no. 46 , p. 948.

Christensen, M. N., 1965, Late Cenozoic deformation in the central Coast Ranges of California: Geological Society of America Bulletin 76, no. 10, p. 1105-1124.

Clifton, H. E., 1968, Possible influence of the San Andreas Fault on middle and probable late Miocene sedimentation, southeastern Caliente Range, in Dickinson, W. R., and Grantz, A. A., eds., Proceedings of conference on geologic problems of San Andreas fault system: Stanford University Publications, Geological Sciences, v. 11, p. 183-190.

-1973, Pebble segregation and bed lenticularity in waveworked versus alluvial gravel: Sedimentology, v. 20, p. 173-187.

1981, Progradational sequences in Miocene shoreline deposits, southeastern Caliente Range, California: Journal of Sedimentary Petrology, v. 51, no. 1, p. 165-184.

Clifton, H. E., Hunter, R. E., and Phillips, R. L., 1971, Depositional structures and processes in the non-barred high-energy nearshore: Journal of Sedimentary Petrology, v. 41, no. 3, p. 651-670.

Cook, P. J., 1967, Winnowing - an important process in the concentration of the Stairway Sandstone (Ordovician) phosphorites of Central Australia: Journal of Sedimentary Petrology, v. 37 , no. 3 , p. $818-828$.

Cross, R: K., 1962, Geology of the Carrizo-Cuyama Basin, in Geology of Carrizo Plains and San Andreas Fault: San Joaquin Geological Society Guidebook, p. 27-35.

Demaison, G. T., and Moore, G. T., 1980, Anoxic environments and oil source bed genesis: Organic Geochemistry, v. 2, no. 1, p. 9-31.

Dibblee, T. W., Jr., 1973a, Regional geologic map of San Andreas and related faults in Carrizo Plain, Temblor, Caliente, and La Panza Ranges and vicinity, California: U.S. Geological Survey Miscellaneous Geological Investigations Map I-757, scale 1:125,000.

1973b, Stratigraphy of the southern Coast Ranges near the San Andreas fault from Cholame to Maricopa, California: U.S. Geological Survey Professional Paper 764, 45 p.

1976, The Rinconada and related faults, in the southern Coast Ranges, California, and their tectonic significance: U.S. Geological Survey Professional Paper 981, 55 p.

Dickert, P. F., 1966, Tertiary phosphatic facies of the Coast Ranges, in Bailey, E. H., ed., Geology of northern California: California Division of Mines and Geology Bulletin 190, p. 289-304. -1971, Neogene phosphatic facies in California: Stanford, Calif., Stanford University, Ph.D. dissertation, 305 p.

Dickinson, W. R., and Grantz, A. A., eds., 1968, Proceedings of conference on geologic problems of San Andreas fault system: Stanford University Publications, Geological Sciences, v. 11, $374 \mathrm{p}$.

Drever, J. I., 1971, Early diagenesis of clay minerals, Rio Ameca Basin, Mexico: Journal of Sedimentary Petrology, v. 41, p. 982-994.

1974, The magnesium problem, in Goldberg, E. D., ed., The Sea, v. 5. Interscience Publishers, p. 337-357.

Dunham, R. J., 1962, Classification of carbonate rocks according to depositional texture, in Ham, W. E., ed., Classification of Carbonate Rocks: American Association of Petroleum Geologist, Memoir 1, p. 108-121.

Durham, D. L., 1974, Geology of the southern Salinas Valley: U.S. Geological Survey Professional Paper 819, $111 \mathrm{p}$.

Eaton, J. E., 1939, Geology and oil possibilities of Caliente Range, Cuyama Valley, and Carrizo Plain, California: California Journal of Mines and Geology, v. 35, no. 3, p. 255-274.

Eaton, J. E., Grant, U. S., and Allen, H. B., 1941, Miocene of Caliente Range and environs: American Association of Petroleum Geologists Bulletin, v. 25, no. 2, p. 193-262.

Eckis, R. E., 1952, Oil fields in Cuyama Valley, in American Association of Petroleum Geologists, Society of Economic Paleontologists and Mineralogists, and Society of Economic Geologists Guidebook, Annual Meeting, Los Angeles, Calif. 1952, p. 88-96.

English, W. A., 1916, Geology and oil prospects of Cuyama Valley, California: U.S. Geological Survey Bulletin 621, p. 191-215.

Fairbanks, H. W., 1904, Description of the San Luis quadrangle [California]: U.S. Geological Survey, Geologic atlas, Folio $101,14 \mathrm{p}$ 
Fedewa, W. T., and Hovland, R. D., 1981, Phosphate resources of the upper Miocene phosphate deposit near New Cuyama, Santa Barbara County, California, in Roberts, A. E., and Vercoutere, T. L., 1981, Geology and petrology of the upper Miocene phosphate deposit near New Cuyama, Santa Barbara County, California: U.S. Geological Survey Open-File Report $81-1037,259 \mathrm{p}$.

Ferrara, G., and Treuil, M., 1975, Petrological implications of trace element and $\mathrm{Sr}$ isotope distributions in basalt-pantellerite series: Bulletin Volcanologique, v. 38, no. 3, p. 548-574.

Fischer, A. G., and Arthur, M. A., 1977, Secular variations in the pelagic realm, in Cook, H. E, and Enos, Paul, eds., Deep-water carbonate environments: Society of Economic Paleontologists and Mineralogists Special Publication, no. 25, p. 19-50.

Folk, R. L., 1957, Petrology of sedimentary rock: Austin, Tex., Hemphill Publishing Company, $170 \mathrm{p}$.

Fritsche, A. E., 1969, Miocene geology of the central Sierra Madre Mountains, Santa Barbara County, California: Los Angeles, Calif., University of California, Ph.D. dissertation, $385 \mathrm{p}$.

1972, Structure of Miocene rocks in the Sierra Madre, northeastern Santa Barbara County, California, in Pacific Coast geology, basis for new exploration, guidebook: American Association of Petroleum Geologists, Society of Economic Paleontologists and Mineralogists, and Society of Exploration Geophysicists, 47th Annual Meeting, Bakersfield, Calif., 1972, $10 \mathrm{p}$.

Goddard, E. N., chm., and others, 1948, Rock-Color Chart: National Research Council, reprinted by Geological Society of America, 1951, 6 p.

Gower, H. D., and Madsen, B. M., 1964, The occurrence of phosphate rock in California, in Short papers in geology and hydrology: U.S. Geological Survey Professional Paper 501-D, p. D79-D85.

Graham, S. A., 1976, Tertiary sedimentary tectonics of the central Salinian block of California: Stanford, Calif., Stanford University, Ph.D. dissertation, 510 p.

1978, Role of Salinian block in evolution of San Andreas fault system, California: American Association of Petroleum Geologists Bulletin, v. 62, no. 11, p. 2214-2231.

Gribi, E. A., Jr., 1963, Salinas basin oil province, in Geology of Salinas Valley and the San Andreas Fault: Society of Economic Paleontologists and Mineralogists, Pacific Section, Guidebook for the Annual Spring Field trip, 1963, p. 16-27.

Gulbrandsen, R. A., 1960 [1961], Petrology of the Meade Peak phosphatic shale member of the Phosphoria Formation at Coal Canyon, Wyoming: U.S. Geological Survey Bulletin 1111-C, p. C71-C146.

1969, Physical and chemical factors in the formation of marine apatite: Economic Geology, v. 64 , no. 4, p. 365-82.

Gulbrandsen, R. A., Roberson, C. E., and Neil, S. T., 1984, Time and crystallization of apatite in seawater: Geochimica et Cosmochimica Acta, v, 48, p. 213-218.

Hill, M. L., Carlson, S. A., and Dibblee, T. W., Jr., 1958, Stratigraphy of Cuyama Valley-Caliente Range area, California: American Association of Petroleum Geologists Bulletin, v. 42, no. 12, p. $2973-3000$.

Hill, M. L., and Dibblee, T. W., Jr., 1953, San Andreas, Garlock, and Big Pine faults, California: Geological Society of America Bulletin, v. 64 , no. 4 , p. 443-458.

Howell, D. G., McLean, H., and Vedder, J. G., 1980, Late Cre- taceous suturing and translation of the Salinian and Nacimiento blocks, California [abs.]: American Geophysical Union Transactions, v. 61 , no. 46 , p. 948.

Howell, D. G., and Vedder, J. G., 1978, Late Cretaceous paleogeography of the Salinian block, California, in Howell, D. G., and McDougall, K. A., eds., Mesozoic Paleogeography of the Western U.S., Pacific Coast Paleogeography Symposium, 2: Special Publication Society Economic Paleontologists and Mineralogists, Pacific Section, p. 523-534.

Howell, D. G., Vedder, J. G., McLean, H., Joyce, J. M., Clarke, S. H., Jr., and Smith, G., 1977, Review of Cretaceous geology, Salinian and Nacimiento blocks, Coast Ranges of central California, in Howell, D. G., Vedder, J. G., and McDougall, K. A., eds., Cretaceous geology of the California Coast Ranges, west of the San Andreas fault,: Society of Economic Paleontologists and Mineralogists, Pacific Section, Pacific Coast Paleogeography Field Guide 2, p. 1-46.

Huffman, O. F., 1972, Lateral displacement of upper Miocene rocks and Neogene history of offset along the San Andreas fault in central California: Geological Society of America Bulletin, v. 83 , no. 10 , p. $2913-2946$.

Johnson, J. D., and Normark, W. R., 1974, Neogene tectonic evolution of the Salinian block, west-central California: Geology, v. 2, no. 1, p. 11-14.

Jones, J. B., and Segnit, E. R., 1971, The nature of opal - I. Nomenclature and constituent phases: Geological Society of Australia Journal, v. 18, pt. 1, p. 57-68.

Kastner, M., Keene, J. B., and Gieskes, J. M., 1977, Diagenesis of siliceous oozes-I. Chemical controls on the rate of opal-A to opal-CT transformation-an experimental study: Geochimica et Cosmochimica Acta, v. 41, no. 8, p. 1041-1059.

Ketchum, B. H., and Redfield, A. C., 1949, Some physical and chemical characteristics of algae grown in mass culture: Journal of Cellular and Comparative Physiology, v. 33, p. 281-300.

Krynine, P. D., 1948, The megascopic study and field classification of sedimentary rocks: Journal of Geology, v. 56, p. 130-165.

Lagoe, M. B., 1984, Paleogeography of Monterey Formation, Cuyama Basin, California: American Association of Petroleum Geologists Bulletin, v. 68 , no. 5, p. 610-627.

Landing, W. M., and Bruland, K. W., 1980, Manganese in the north Pacific: Earth and Planetary Science Letters, v. 49, p. 45-56.

Maher, J. C., 1959, The composite interpretive method of logging drill cuttings: Oklahoma Geological Survey Guidebook 8, 48 p.; 2d ed. 1964 as Guidebook 14.

Majmundar, H. H., 1975, Danger of cadmium contamination from phosphatic rocks in the King City-Paso Robles area, California [abs.]: Geological Society of America Abstracts with Programs, v. 7, no. 3, p. 342-343.

Manheim, F. T., and Gulbrandsen, R. A., 1979, Marine phosphorites, in Marine minerals: Mineralogical Society of America Short Course Notes, v. 6, chap. 6, p. 151-173.

Manheim, F. T., Rowe, G. T, and Jipa, D., 1975, Marine phosphorite formation off Peru: Journal of Sedimentary Petrology, v. 45 , no. 1 , p. $243-251$.

Martens, C. S., and Harriss, R. C., 1970, Inhibition of apatite precipitation in the marine environment by magnesium ions: Geochimica et Cosmochimica Acta, v. 34, p. 621-625.

Martin, J. H., and Knauer, G. A., 1973, The elemental composition of plankton: Geochimica et Cosmochimica Acta, v. 37, p. 1639-1653. 
Murata, K. J., and Larson, R. R., 1975, Diagenesis of Miocene siliceous shales, Temblor Range, California: U. S. Geological Survey Journal of Research, v. 3, no. 5, p. 553-566.

Murata, K. J., and Nakata, J. K., 1974, Cristobalitic stage in the diagenesis of diatomaceous shale: Science, v. 184, p. 567-568.

Page, B. M., 1970, Sur-Nacimiento fault zone of CaliforniaContinental margin tectonics: Geological Society of America Bulletin, v. 81 , no. 3 , p. 667-689.

1981, The southern Coast Ranges, in Ernst, W. G., ed., The geotectonic development of California: Englewood Cliffs, $\mathrm{N}$. J., Prentice-Hall, p. 329-417.

Phillips, L. R., 1981, Depositional environments of the Santa Margarita Formation in the Santa Cruz Mountains, California: Santa Cruz, Calif., University of California, Ph.D. dissertation, $343 \mathrm{p}$.

Powers, M. C., 1953, A roundness scale for sedimentary particles: Journal of Sedimentary Petrology, v. 23, p. 117-119.

Price, N. B., and Calvert, S. E., 1978, The geochemistry of phosphorites from the Namibian Shelf: Chemical Geology, v. 23, no. 2 , p. $151-170$.

Reed, R. D., 1933, Geology of California: Tulsa, Okla., American Association of Petroleum Geologists, $186 \mathrm{p}$.

Repenning, C. A., and Vedder, J. G., 1961, Continental vertebrates and their stratigraphic correlation with marine mollusks, eastern Caliente Range, California, in Short papers in the geologic and hydrologic sciences: U.S. Geological Survey Professional Paper 424-C, p. C235-C239.

Richards, G. L., Jr., 1933, Geology of the Santa Margarita Formation, San Luis Obispo County, California: Stanford, Calif., Stanford University, M.A. thesis, 182 p.

Riggs, S. R., 1979, Phosphorite sedimentation in Florida-a model phosphogenic system: Economic Geology, v. 74, no. 2, p. 285-314.

Roberts, A. E., 1979, Analytical and stratigraphic data on the upper phosphatic mudstone member of the Santa Margarita Formation at Newsome Canyon, southern Cuyama Valley, California: U.S. Geological Survey Open- File Report 79-1466, 64 p.

1981, Phosphatic rock localities in California: U.S. Geological Survey Open-File Report 81-260, 76 p.

Ross, C. S., and Hendricks, S. B., 1945, Minerals of the montmorillonite group: U.S. Geologicàl Survey Professional Paper 205-B, $79 \mathrm{p}$.

Ross, D. C., 1972, Petrographic and chemical reconnaissance study of some granitic and gneissic rocks near the San Andreas fault from Bodega Head to Cajon Pass, California: U.S. Geological Survey Professional Paper 698, 92 p.

1974, Map showing basement geology and location of well drilled to basement, Salinian block, central and southern Coast Ranges, California: U.S. Geological Survey Miscellaneous Field Studies Map MF-588, scale 1:500,000.

1978, The Salinian Block-a Mesozoic granite orphan in the California Coast Ranges, in Howell, D. G., and McDougall, K. A., eds., Mesozoic Paleogeography of the Western U.S., Pacific Coast Paleogeography symposium, 2: Special Publication Society Economic Paleontologists and Mineralogists, Pacific Section, p. 509-522.

Schwade, I. T., Carlson, S. A., and O'Flynn, J. B., 1958, Geologic environment of Cuyama Valley oil fields, California, in Weeks, L. G., ed., Habitat of oil: Tulsa, Okla., American Association of Petroleum Geologists, p. 78-98.
Sheldon, R. P., 1981, Ancient marine phosphorites: Annual Review of Earth and Planetary Sciences, v. 9, 35 p.

Sholkovitz, E. R., 1972, The chemical and physical oceanography and the interstitial water chemistry of the Santa Barbara Basin: San Diego, Calif., University of California, Ph.D. dissertation, $176 \mathrm{p}$.

Slaughter, M., and Earley, J. W., 1965, Mineralogy and geological significance of the Mowry bentonites, Wyoming: Geological Society of America Special Publication 83, $116 \mathrm{p}$.

Thompson, M. E., 1953, Distribution of uranium in rich phosphate beds of the Phosphoria formation: U. S. Geological Survey Bulletin 988-D, p. D45-D67.

1954 , Further studies of the distribution of uranium in rich phosphate beds of the Phosphoria formation: U. S. Geological Survey Bulletin 1009-D, p. D107-D123.

Turekian, K. K., 1977, The fate of metals in the oceans: Geochimica et Cosmochimica Acta, v. 41, no. 8, p. 1139-1140.

Vail, P. R., Mitchum, R. M., Jr., and Thompson, S., III, 1977, Global cycles of relative changes of sea level, in Payton, C. E., ed. , Seismic stratigraphy - applications to hydrocarbon exploration: American Association of Petroleum Geologists Memoir 26, p. 83-97.

Vedder, J. G., 1968, Geologic map of Fox Mountain quadrangle, Santa Barbara County, California: U.S. Geological Survey Miscellaneous Geological Investigations Map I-547, scale $1: 24,000$.

1973, Geologic framework and correlation of Miocene rocks in the Caliente Range, in Sedimentary facies changes in Tertiary rocks - California Transverse and southern Coast Ranges: Society of Economic Paleontologists and Mineralogists Field Trip 2 Guidebook, 1973 Annual Meeting, Anaheim, Calif., p. $42-53$.

1975, Juxtaposed Tertiary strata along the San Andreas Fault in the Temblor and Caliente Ranges, California: California Division of Mines and Geology, Special Report 118, p. 234-240.

Vedder, J. G., and Brown, R. D., Jr., 1968, Structural and stratigraphic relations along the Nacimiento fault in the southern Santa Lucia Range and San Rafael Mountains, California, in Dickinson, W. R., and Grantz, A. A., eds., Proceedings of conference on geologic problems of San Andreas fault system: Stanford University Publications, Geological Sciences, v. 11, p. 242-259.

Vedder, J. G., Howell, D. G., and McLean, H., 1980, Upper Cretaceous red beds-evidence for early suturing of the Nacimiento and Salinian blocks, California [abs.]: Geological Society of America Bulletin, v. 12, no. 3, p. 157-158.

Vedder, J. G., and Repenning, C. A., 1975, Geologic map of the Cuyama and New Cuyama quadrangles, San Luis Obispo and Santa Barbara Counties, California: U.S. Geological Survey Miscellaneous Geological Investigations Map I-876, scale 1:24,000.

Welday, E. E., and Williams, J. W., 1975, Offshore surficial geology of California: California Division of Mines and Geology, Map Sheet 26, scale 1:500,000.

Wentworth, C. M., 1968, Upper Cretaceous and lower Tertiary strata near Gualala, California, and inferred large right slip on the San Andreas Fault, in Dickinson, W. R., and Grantz, A. A., eds., Proceedings of conference on geologic problems of San Andreas fault system: Stanford University Publications, Geo- 
logical Sciences, v. 11, p. 144-165.

Zulberti, J. L., 1954, South Cuyama oil field: California Division of Oil and Gas, California Oil Fields-Summary of Operations, v. 40, no. 1, p. 41-45. 

STRATIGRAPHIC SECTIONS AND TABLES 7-12 


\section{STRATIGRAPHIC SECTIONS}

The upper Miocene rocks in the area of Cuyama Valley phosphate deposit consist of resistant sandstone members and nonresistant phosphatic mudstone members; the latter generally are not exposed. The upper phosphate mudstone member was exposed by trenching for detailed examination and sampling. The sites for trenching were selected at those places where geologic mapping indicated less structural complications and on steep slopes where depth of weathering was at a minimum. Locations of the trenches are shown on the geologic map (pl. 1) and on the structure contour map (pl. 3).

Trenching was done by Nicols Industrial Minerals Corporation in 1963 and by Cuyama Phosphate Corporation in 1965. The trenches of the Nicols Industrial Minerals Corporation are numbered 294, 295, 296, 297, 298, 299, 300, and 301, and those of the Cuyama Phosphate Corporation are numbered 50, 75, 100, 200,300,400,500,600, and 700. Nicols trench 299 is the same as Cuyama Phosphate trench 75; trench 300 is the same for both; and Nicols trench 296 is the same as Cuyama Phosphate trench 600. Since the cutting of these trenches, the phosphate rocks have eroded and slumped; therefore, they are now of little analytical value. Trench 100 , which was recut by Cuyama Phosphate Corporation in 1978, provided the detailed information for this report and is designated herein a reference section. A geologic column showing location of lithologic samples and analytical data for the reference section in trench 100 is shown on plate 4 .

\section{Stratigraphic section of the upper phosphatic mudstone member, Santa Margarita Formation of Cuyama Valley phosphate area, Santa Barbara County, Calif.}

\section{Trench 100 (Reference Section)}

The section was measured and sampled by A. E. Roberts and L. E. Mack in the Cuyama Phosphate Corporation trench 100 in 1978. Many contacts are gradational, therefore, the divisions between these stratigraphic units were arbitrarily chosen depending on pellet content. The samples were described petrographically by T. L. Vercoutere and A. E. Roberts. Pellet-bearing rocks were examined for mineral structure by $\mathrm{L}$. E. Mack with the Cambridge Stereoscan 180 Scanning Electron Microscope (SEM) equipped with an Energy Dispersive Analysis of X-rays (EDAX) system. Point count, specific gravity, and $\mathrm{X}$-ray diffraction analyses were made by $\mathrm{T}$. $\mathrm{L}$. Vercoutere. Analytical data are presented in the lists of chemical and X-ray analyses. LOCATION: NE $1 / 4$ SW $1 / 4$ sec. 7, T. 9 N., R. 26 W. (S.B.B. \& M.) in the New Cuyama, California Quadrangle.

ATTITUDE OF BEDDING: The average bedding strike is N. $60^{\circ} \mathrm{W}$., and the bedding dip varies from $50^{\circ} \mathrm{SW}$. at unit 53 , to $80^{\circ} \mathrm{SW}$. at unit 37 , to $69^{\circ} \mathrm{SW}$. at unit 12 , all overturned.

\section{Upper Miocene: \\ Santa Margarita Formation: \\ Upper sandstone member: Unit No.}

68. Sandstone, light-yellowish-gray (5Y9/1), thick, very fine to coarse-grained, poorly sorted, subangular to rounded grains, friable. Framework, 50 percent quartz, 15 percent feldspar, and less than 1 percent phosphatic pellets; matrix, 30 percent clay minerals, 4 percent carbonate. Specific gravity 2.36 . Sample 100-1 from base of unit.
Upper Miocene:

Santa Margarita Formation:

Upper phosphatic mudstone member: Unis No.

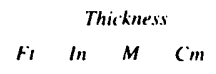

67. Claystone, siliceous, light-olivegray (5Y6/1), massive, angular to subrounded grains, poorly sorted. Framework, 15 percent quartz, 4 percent feldspar, and 7 percent phosphatic pellets; matrix, 59 percent clay minerals, 11 percent opal, and 4 percent iron oxide. Quartz, albite, orthoclase, opal-CT, montmorillonite, and a trace of apatite(?) were detected by $\mathrm{X}$ ray diffraction analysis. Specific gravity, 1.99. Sample 100-2 from middle of unit.

66. Mudstone, silty, dolomitic, lightgray (N7) to light-olive-gray (5Y6/1) with moderate-brown (5YR4/4) iron oxide and black (N1) pyrolusite coatings, massive to faintly laminated, indurated, angular to subrounded grains, mediumsorted, slightly bioturbated; pelecypod casts and molds common, and diatoms and sponge spicules rare in upper $10 \mathrm{ft}(3.05 \mathrm{~m})$. Sample 100-3c contains 17 percent quartz, 6 percent feldspar, 2 percent phosphatic pellets and nodules, 4 percent clay minerals, 62 percent dolomite, 6 percent opal, and 3 percent iron oxide. Quartz, albite, orthoclase, dolomite, and a trace of opal-CT and montmorillonite were detected by $\mathrm{X}$-ray diffraction analysis. Sample 100-3a col-

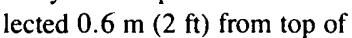
unit, specific gravity, 2.09 ; sample $100-3 \mathrm{~b}$ collected $1.8 \mathrm{~m}$ (6 ft) from top, specific gravity, 1.90; sample 100-3c collected $3 \mathrm{~m}$ (10 ft) from top, specific gravity, 2.22; sample 100-3d

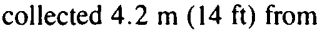
top, specific gravity, 2.06 .

65. Bentonite, slightly silty, olivegray (5Y3/2) with light-brown (5YR5/6) iron-oxide stain, waxy luster, flaky texture, plastic when wet, nonphosphatic. Montmorillonite, quartz, albite, orthoclase, and illite were detected by $\mathrm{X}$-ray diffraction analysis. Sample 100-4 from middle of unit.

64. Claystone, siliceous, light-duskyyellow (5Y7/4) when fresh, weathers yellowish-gray (5Y8/1), indurated, laminated; 
Upper Miocene-Continued

Santa Margarita Formation-Continued Upper phosphatic mudstone member-Continued Unit No.

$$
\text { Fi In } M \quad C m
$$

angular to subangular grains, poorly sorted; floating grains as large as medium size, rare; fish scales, rare. Framework, 5 percent quartz, 1 percent feldspar; matrix 84 percent clay minerals, 7 percent opal, and 3 percent iron oxide. Opal-CT, quartz, albite, orthoclase, and montmorillonite were detected by X-ray diffraction analysis. Specific gravity, 1.64. Sample 100-5 from middle of unit.

63. Mudstone, siliceous, very light gray (N8) with dark-yellowishorange (10YR6/6) iron-oxide stains and black (N1) pyrolusite coatings, massive, indurated; grains angular to subangular, poorly sorted; floating grains as large as medium size, rare; pelecypod molds common, fish scales rare. Framework, 7 percent quartz, 3 percent feldspar, 1 percent heavy minerals; matrix, 21 percent clay minerals, 62 percent opal, and 6 percent iron oxide. Opal-CT, quartz, albite, orthoclase, illite, and montmorillonite were detected by $\mathrm{X}$-ray diffraction analysis. Specific gravity, 1.67. Sample 100-6 from middle of unit.

62. Sandstone, very fine grained, clayey, moderately phosphatic, grayish-orange (10YR7/4), thick, massive, indurated; small grains angular to subrounded, larger grains subangular to rounded, poorly sorted. Phosphatic pellets and nodules in lower $18 \mathrm{~cm}$ ( 7 in.), pelecypod molds to $4 \mathrm{~cm}$ size abundant, shell fragments rare, and fish bones rare. Framework, 32 percent quartz, 4 percent feldspar, 1 percent carbonate fragments, 16 percent phosphatic pellets and nodules, 3 percent accessory minerals; matrix, 35 percent clay minerals, 1 percent carbonate, and 8 percent iron oxide. Quartz, albite, orthoclase, apatite, and illite were detected by X-ray diffraction analysis. Specific gravity, 2.31. Irregular basal contact. Sample 100-7 from base of unit.
Upper Miocene-Continued

Santa Margarita Formation-Continued Upper phosphatic mudstone member-Continued Unit No. Thickness Ft In $\quad M \quad C m$

(5Y6/1) with very dark yellowish orange (10YR5/6) ironoxide stains and black ( $\mathrm{Nl}$ ) pyrolusite coatings, massive, indurated; small grains angular to subangular, larger grains subangular to rounded, poorly sorted; floating grains medium to coarse, abundant. Contains phosphatic pellets, diatoms common, foraminifers, pelecypod molds, and fish scales. Framework, 33 percent quartz, 4 percent feldspar, 1 percent carbonate fragments, 2 percent chert, 23 percent phosphatic pellets, 1 percent chlorite, and 1 percent heavy minerals; matrix, 7 percent clay minerals, 10 percent carbonate, 6 percent apatite, and 12 percent iron oxide. Quartz, albite, orthoclase, apatite, and dolomite were detected by X-ray diffraction analysis. Specific gravity, 2.19. Sample 100-8 from middle of unit.

60. Siltstone, sandy (fine- to coarsegrained), very phosphatic, yellowish-gray (5Y7/2) with moderate-brown (5YR4/4) iron-oxide stain, friable to moderately indurated, grains subangular to rounded, poorly sorted. Fish bones common. Framework, 13 percent quartz, 8 percent feldspar, 40 percent phosphatic pellets, and 3 percent heavy minerals; matrix, 19 percent clay minerals, 3 percent carbonate, 6 percent apatite, and 8 percent iron oxide. Specific gravity, 2.35. Sample 100-9 from middle of unit. Correlation unit P1.

59. Siltstone, phosphatic, very light brownish gray (5YR7/1) to light-gray (N7), massive, indurated, poorly sorted, floating grains fine- to coarse-size and angular to subrounded common, phosphatized fish scales common, fish bones and diatom molds rare. Framework, 28 percent quartz, 3 percent feldspar, 20 percent phosphatic pellets, and 1 percent accessory minerals; matrix, 28 percent clay minerals, 1 percent carbonate, 11 percent opal and 8 percent iron oxide. Quartz, albite, orthoclase, apatite, and a 
Upper Miocene-Continued

Santa Margarita Formation-Continued

Upper phosphatic mudstone member-Continued Unit No.

trace of opal-CT and montmorillonite(?) were detected by $\mathrm{X}$-ray diffraction analysis. Basal $30 \mathrm{~cm}$ (12 in.) is sandy siltstone, light-olivegray $(5 \mathrm{Y} 6 / 1)$, with 40 percent phosphatic pellets; marine mammal bone fragments at base. Irregular sharp contact with underlying unit. Specific gravity, 1.90. Sample 100-10

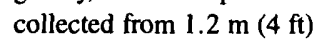
from top.

58. Mudstone, moderately phosphatic, dark-yellowish-gray (5Y7/1) with moderate-olivebrown (5Y4/4) stains along joints, indurated, grains subangular to rounded, poorly sorted, floating grains as large as coarse size rare; faint bedding defined by laminae of phosphatic diatoms and fish scales. Framework, 8 percent quartz, 1 percent feldspar, 10 percent phosphatic pellets, and 3 percent heavy minerals; matrix, 41 percent clay minerals, 1 percent carbonate, 30 percent opal, and 6 percent iron oxide. Quartz, albite, orthoclase, opal-CT, montmorillonite, and illite were detected by $\mathrm{X}$-ray diffraction analysis. Specific gravity, 1.87. Sample 100-11 from middle of unit.

57. Siltstone, phosphatic, sandy (very fine grained), mottled yellowish-gray (5Y7/2) to darkorangish-brown (10YR4/6), poorly sorted, floating grains fine- to medium-size-common, grains subangular to subrounded; swirled bedding, slightly burrowed; disc-shaped phosphatized diatoms abundant (cores of some pellets are the diatom genus Coscinodiscus); fish bones and scales, intraclasts of siliceous mudstone rare. Framework, 20 percent quartz, 4 percent feldspar, 37 percent phosphatic pellets, and 3 percent heavy minerals; matrix, 18 percent clay minerals, 5 percent apatite, 10 percent opal, and 3 percent iron oxide. Quartz, apatite, albite, orthoclase, and a trace of calcite(?) and opal-CT were detected by $\mathrm{X}$-ray diffraction
Upper Miocene-Continued

Santa Margarita Formation-Continued

Upper phosphatic mudstone member-Continued Unit No.

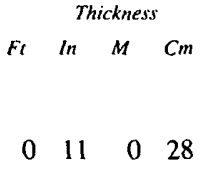

56. Claystone, moderately phosphatic, dark-yellowish-gray (5Y8/1) with light-brown (5YR5/6) stains, faintly laminated, grains subangular to subrounded, floating grains to medium size, rare, poorly sorted. Pelecypod molds as much as $5 \mathrm{~cm} \mathrm{(2} \mathrm{in.)} \mathrm{in} \mathrm{diame-}$ ter rare; fish scales and pelletfilled burrows rare. Framework, 5 percent quartz, 2 percent feldspar, 16 percent phosphatic pellets, and 2 percent glauconite; matrix, 57 percent clay minerals, 9 percent carbonate, and 9 percent iron oxide. Quartz, apatite, albite, orthoclase, gypsum, calcite, and a trace of illite were detected by $\mathrm{X}$-ray diffraction analysis. Specific gravity, 2.24. Sample 100-13 from middle of unit.

55. Phosphorite, silty, slightly calcareous, light-gray (N7) but mostly stained very dark yellowish-orange (10YR5/6), massive, grains subangular to subrounded, indurated, well sorted but with some floating grains to coarse size; fish bones and scales common; mudstone intraclasts to $2 \mathrm{~cm}$ rare. Framework, 11 percent quartz, 6 percent feldspar, 56 percent phosphatic pellets, and 1 percent zeolite mineral(?); matrix, 11 percent clay minerals, 11 percent carbonate, and 4 percent iron oxide. Specific gravity 2.47 . Sample 100-14 from middle of unit. Correlation unit $\mathbf{P} 2$.

54. Mudstone, moderately phosphatic, siliceous, light-gray (N7) to light-greenish-gray (5GY7/1) with moderate-olivebrown (5Y4/4) stains along joints, massive, indurated, floating grains to fine size, rare, grains subangular to subrounded, medium-sorte, pelecypod molds to $5 \mathrm{~cm}$ (2 in.), fish scales, diatom molds common, and burrows rare. Framework, 11 percent quartz, and 11 percent phosphatic pellets; matrix, 36 percent clay 
Upper Miocene-Continued

Santa Margarita Formation-Continued

Upper phosphatic mudstone member-Continued Unir No.

$$
\begin{aligned}
& \text { Thickness } \\
& \text { Fl In M Cm }
\end{aligned}
$$

minerals, 36 percent opal, and 6 percent iron oxide. Specific gravity, 1.87. Sample 100-15 from middle of unit. Correlation unit S1.

53. Mudstone, very phosphatic, yellowish-gray (5Y8/1) but typically stained very dark yellowish orange (10YR6/6), massive, friable to moderately indurated, medium-sorted, grains subangular to subrounded, floating grains to coarse size rare, slightly burrowed, fish bones rare, siliceous mudstone intraclasts rare. Framework, 10 percent quartz, 1 percent feldspar, 45 percent phosphatic pellets, and 4 percent zeolite minerals(?); matrix, 18 percent clay minerals, 3 percent carbonate, and 19 percent iron oxide. Apatite, quartz, albite, orthoclase, and a trace of calcite were detected by $\mathrm{X}$-ray diffraction analysis. Specific gravity, 2.05. Sample $100-16$ from middle of unit.

52. Mudstone, very phosphatic, sandy, dark-yellowish-gray (5Y7/1) with moderate-brown (5YR4/4) and black (NI) stains, massive to faintly laminated, indurated, grains subangular to rounded, medium-sorted, floating grains to coarse size very rare, and small phosphatic claystone nodules rare; fish scales common, pelecypod molds rare. Framework, 21 percent quartz, 5 percent feldspar, 1 percent carbonate fragments, and 41 percent phosphatic pellets and nodules; matrix, 23 percent clay minerals, 1 percent carbonate, 6 percent opal, and 3 percent iron oxide. Quartz, albite, orthoclase, apatite, opal$\mathrm{CT}$, montmorillonite, and a trace of illite were detected by $\mathrm{X}$-ray diffraction analysis. Specific gravity, 2.01. Sample 100-17 from middle of unit.

51. Sandstone, grayish-orange (10YR7/4) with dark-yellowish-orange (10YR6/6) stains, phosphatic, dolomitic, graded bedding, indurated to weakly indurated, grains range from very fine to coarse size; poorly sorted, fish scales common,
Upper Miocene-Continued

Santa Margarita Formation-Continued

Upper phosphatic mudstone member-Continued Unit No.

fish vertebrae and gastropod casts rare, mudstone intraclasts to $8 \mathrm{~cm}$ ( $3 \mathrm{in}$.); silty at base, grains vary from subangular to rounded, phosphatic pellets and nodules at base decrease in size and number upward. Framework, 23 percent quartz, 8 percent feldspar, 3 percent carbonate fragments, 33 percent phosphatic pellets and nodules, and 3 percent zeolite minerals(?); matrix, 6 percent clay minerals, 12 percent carbonate, and 12 percent iron oxide. Quartz, albite, orthoclase, apatite, dolomite, and calcite, were detected by $\mathrm{X}$-ray diffraction analysis. Specific gravity, 2.24. Sample 100-18 from middle of unit.

50. Claystone, yellowish-gray (5Y5/1) to light-olive-gray $(5 Y 6 / 1)$ with light-olive-brown (5Y5/6) stains, massive to faintly laminated, indurated, angular to subangular grains, mediumsorted, floating grains to coarse size and claystone nodules rare; pelecypod molds abundant, fish scales and diatoms rare. Contains a few very light gray (N8) zones of leached phosphatic pellets and molds of pellets. Framework, 7 percent quartz, 1 percent phosphatic pellets, and 1 percent heavy minerals; matrix, 55 percent clay minerals, 5 percent carbonate, 23 percent opal, and 8 percent iron oxide. Quartz, albite, orthoclase, opal$\mathrm{CT}$, and dolomite were detected by $\mathrm{X}$-ray diffraction analysis. Specific gravity, 1.94. Sample 100-19 from middle of unit.

49. Sandstone, siliceous, darkgrayish-orange (10YR6/4), phosphatic, silty, graded bedding, moderately indurated, fine- to coarse-grained, angular to subrounded grains, mediumsorted, floating grains to coarse size abundant, and nodules rare, phosphatic pellets content decreases upward; fish bones and scales common, pelecypod molds abundant. Framework, 27 percent quartz, 3 percent feldspar, 30 percent phosphatic pellets, and 2 percent zeolite 
Upper Miocene-Continued

Santa Margarita Formation-Continued

Upper phosphatic mudstone member-Continued Unit No.

$$
\text { Thickness }
$$

minerals(?); matrix, 24 percent clay minerals, 10 percent opal, and 4 percent iron oxide.

Quartz, albite, orthoclase, apatite, opal-CT, and a trace of illite and montmorillonite were detected by $\mathrm{X}$-ray diffraction analysis. Specific gravity, 2.19. Sample 100-20 from middle of unit. Correlation unit S2.

48. Phosphorite, sandy (very fine to fine-grained), and calcareous, grayish-orange (10YR7/4), massive, weakly indurated, subangular to rounded grains, poorly sorted, floating grains as large as granule size common; phosphatic and siliceous fishbone and shell fragments abundant, pelecypod casts rare; burrows at basal contact common; sharp irregular erosional contact with underlying mudstone. Framework, 15 percent quartz, 5 percent feldspar, 52 percent phosphatic pellets (cores of some pellets are the diatom genus Coscinodiscus) and nodules, and 2 percent zeolite minerals(?); matrix, 16 percent clay minerals, and 10 percent iron oxide. Apatite, quartz, albite, and orthoclase were detected by $\mathrm{X}$-ray diffraction analysis. Specific gravity,

2.16. Sample 100-21 from middle of unit.

47. Mudstone, siliceous, slightly to moderately phosphatic, yellowish-gray (5Y8/1) with lightbrown (5YR5/6) stains, faintly laminated, indurated, poorly sorted, floating grains as large as coarse size rare; phosphatic claystone nodules common; fish scales very abundant, fish bones rare, burrows rare. Quartz, albite, orthoclase, opalCT, apatite, and a trace of montmorillonite were detected by $\mathrm{X}$-ray diffraction analysis. Specific gravity, 1.77. Sample 100-22 from middle of unit.

46. Phosphorite, dolomitic, sandy (fine-grained), light-gray (N7) to grayish-orange (10YR7/4), massive to faintly bedded, moderately indurated, angular to rounded grains, very poorly sorted, floating grains as large as coarse size common; phosphatic framework consists of pellets, claystone nodules,
Upper Miocene-Continued

Santa Margarita Formation-Continued

Upper phosphatic mudstone member-Continued Unit No.

$$
\text { Ft In } \quad M \quad C m
$$

shell and bone fragments, fish scales, and megafossil casts rare. Framework, 14 percent quartz, 5 percent feldspar, 16 percent dolomite, and 60 percent phosphatic pellets and nodules; matrix, 12 percent clay minerals, 7 percent dolomite, and 6 percent iron oxide. Quartz, apatite, albite, orthoclase, and dolomite were detected by $\mathrm{X}$-ray diffraction analysis. Specific gravity, 2.14. Sample 100-23 from middle of unit.

45. Porcellanite, dolomitic, very light gray (N8) to very pale orange (10YR4/4) with black (N1) stains, massive, very indurated, highly fractured. Specific gravity, 2.28. Sample 100-24 from middle of unit.

44. Mudstone, siliceous, very light brownish gray (5YR7/1) with light-olive-brown (5Y5/6) stains, massive, very indurated, subangular to subrounded grains, poorly sorted; contains very light gray (N8) phosphatic pellets rare, molds of pellets common, phosphatic claystone grains rare, fish scales common, fish bones rare, diatom molds and megafossils rare. Unit appears altered to iron oxide and clay-size minerals. Quartz, albite, orthoclase, opalCT, and montmorillonite were detected by X-ray diffraction analysis. Specific gravity, 1.68. Sample 100-25 from middle of unit.

43. Mudstone, phosphatic, siliceous, yellowish-gray $(5 Y 7 / 1)$ with some black (N1) pyrolusite(?) coatings, faintly laminated, indurated, angular to subrounded grains, mediumsorted, floating grains as large as coarse size rare. Slightly to very phosphatic with pellet concentrations exceeding 50 percent in upper 8 in. $(20 \mathrm{~cm})$; phosphatic claystone nodules rare, pellet- filled burrows common. Framework, 26 percent quartz, 7 percent feldspar, 20 percent phosphatic pellets, and 3 percent zeolite minerals(?); matrix, 31 percent clay minerals, 1 percent carbonate, 8 percent opal, and 4 percent iron oxide. Quartz, albite, 
Upper Miocene-Continued

Santa Margarita Formation-Continued

Upper phosphatic mudstone member-Continued Unit No.

$$
\text { Ft } \begin{array}{lll}
\multicolumn{4}{c}{\text { Thickness }} \\
\text { In } & M & C m
\end{array}
$$

orthoclase, opal-CT, apatite, and illite were detected by $\mathrm{X}$ ray diffraction analysis. Specific gravity, 2.04. Sample 100-26 from middle of unit.

42. Phosphorite, very light gray (N8)

to dark-yellowish-gray $(5 Y 7 / 1)$ with light-olive-brown (5Y5/6) and moderate-brown (5YR4/4) stains, massive to faintly bedded, indurated; local concentrations of pellets, phos phatic claystone nodules rare, and fish scales common.

Framework, 11 percent quartz, 6 percent feldspar, and 53 percent phosphatic pellets; matrix, 26 percent clay minerals, and 4 percent iron oxide. Quartz, albite, orthoclase, and opal-CT were detected by X-ray diffraction analysis. Specific gravity, 1.92. Sample 100-27 from middle of unit.

41. Mudstone, siliceous, light-gray (N7) to yellowish-gray (5Y8/1) with light-olive-brown (5Y5/6) stains, faintly laminated, indurated, angular to subangular grains, poorly sorted, floating grains to coarse size common. Slightly phosphatic with scattered phosphatic claystone nodules and lenses of molds of petlets, fish scales, and megafossils common. Contains 15 percent quartz, 4 percent phosphatic pellets and nodules, 1 percent accessory minerals, and 80 percent altered matrix of clay, opal, and iron-oxide minerals. Opal-CT, quartz, albite, orthoclase, montmorillonite, and illite were detected by $\mathrm{X}$-ray diffraction analysis. Specific gravity, 1.80 Sample 100-28 from middle of unit.

40. Sandstone, phosphatic, calcareous, silty, yellowish-gray $(5 Y 7 / 2)$ and light-gray (N7) to yellowish-gray $(5 \mathrm{Y} 8 / 1)$ mudstone lenses, massive, indurated; swirled mudstone laminations, rare, predominantly very fine, angular to subangular grains, mediumsorted, floating grains to coarse size abundant; fish bones and scales, phosphatic nodules, and pellet-filled burrows rare. Framework, 15 percent quartz, 3 percent feldspar, 5 percent
Upper Miocene-Continued

Santa Margarita Formation-Continued

Upper phosphatic mudstone member-Continued Unit No.

Thickness

carbonate fragments, and 38

percent phosphatic pellets and nodules; matrix, 1 percent clay minerals, 36 percent carbonate, and 2 percent iron oxide.

Quartz, albite, orthoclase, calcite, and apatite were detected by $\mathrm{X}$-ray diffraction analysis. Specific gravity, 2.40. Sample 100-29 from middle of unit.

39. Porcellanite, silty, yellowish-gray (5Y8/1) to light-gray (N7) with dark-grayish-orange (10YR6/4) and black (NI) coatings, laminations faint and even, indurated, angular to subangular grains, poorly sorted, floating grains to fine size very rare. Contains fish scales and megafossils common; phosphatic pellets and phosphatic claystone nodules rare. Opal$\mathrm{CT}$, quartz, albite, orthoclase, and illite were detected by $\mathrm{X}$ ray diffraction analysis. Specific gravity, 1.67. Sample 100-30 from middle of unit.

38. Siltstone, phosphatic, sandy, mottled yellowish-gray $(5 Y 8 / 1)$ to very pale brown (5YR6/2) with light-brown (5YR5/6) stains, massive, indurated, angular to subrounded grains, poorly sorted, floating grains to coarse size common, coarse grains and nodules of phosphatic claystone rare. Contains fish bones and scales common, phosphatic pellet-filled burrows common, one crab(?) skeletal fragment. Framework, 21 percent quartz, 6 percent feldspar, 2 percent carbonate fragments, 1 percent chert, 21 percents phosphatic pellets and nodules, and I percent glauconite; matrix, 16 percent clay minerals, 1 percent carbonate, 26 percent opal, and 31 percent iron oxide. Locally contains as much as 40 percent pellets. Quartz, albite, apatite, orthoclase, and opal-CT were detected by $\mathrm{X}$-ray diffraction analysis. Specific gravity, 2.01 . Sample 100-31 from middle of unit.

37. Mudstone, siliceous, slightly silty, light- to very light gray (N7N8) with many moderatebrown (5YR4/4) and black (NI) stains, massive, indurated, angular to rounded grains, 
Upper Miocene-Continued

Santa Margarita Formation-Continued

Upper phosphatic mudstone member-Continued Unit No.

$$
\text { Ft In } \begin{array}{cc}
\text { Thickness } \\
\mathrm{Cm}
\end{array}
$$

medium-sorted, floating grains to coarse size rare. Contains molds of peltets locally concentrated in lenses rare, phosphatic claystone nodules rare, diatom molds abundant, fish scales and megafossils common, and one crab(?) skeletal fragment. Opal-CT, quartz, albite, orthoclase, and montmorillonite were detected by $\mathrm{X}$-ray diffraction analysis. Specific gravity, 1.64. Sample 100-32 from middle of unit. Correlation unit $\mathrm{S} 3$.

36. Siltstone, phosphatic, sandy (finegrained), very pale yellowish brown (10YR7/2) with lightbrown (5YR6/4) stains, faintly laminated, indurated, angular to subrounded grains, poorly sorted, floating grains to fine size common, phosphatic claystone nodules rare. Contains pelecypod molds as much as $5 \mathrm{~cm}$ in diameter rare. Framework, 17 percent quartz, 1 percent feldspar, and 27 percent phosphatic pellets (cores of some pellets are the diatom genus Coscinodiscus); matrix, 30 percent clay minerals, 20 percent opal, and 5 percent iron oxide. Quartz, apatite, albite, opal-CT, and orthoclase were detected by X-ray diffraction analysis. Specific gravity,

1.76. Sample 100-33 from middle of unit.

35. Mudstone, moderately phosphatic, silty, dark-yellowishgray (5Y7/1) to light-gray (N7) with dusky-yellow (5Y6/4), light-brown (5YR5/6) and black (NI) stains, massive, indurated, angular to subrounded grains, poorly sorted, floating grains to coarse size common, grayish-pink (5R8/2) phosphatic claystone nodules rare. Contains fish bones and scales rare. Framework, 17 percent quartz, 5 percent feldspar, 1 percent carbonate fragments, and 17 percent phosphatic pellets; matrix, 21 percent clay minerals, 2 percent carbonate, 30 percent opal, and 7 percent iron oxide. Quartz, albite, apatite, orthoclase, opal-CT, and montmorillonite were detected by $\mathrm{X}$-ray diffraction analysis. Specific gravity, 1.91. Sample
Upper Miocene-Continued

Santa Margarita Formation-Continued

Upper phosphatic mudstone member-Continued Unit No.

Thickness

100-34 from middle of unit.

Ft In $M \quad C m$

$\begin{array}{llll}2 & 6 & 0 & 76\end{array}$

34. Mudstone, phosphatic, yellowishgray $(5 Y 8 / 1)$ with light-brown (5YR5/6) stains, faintly laminated, indurated, subangular to subrounded grains, poorly sorted, floating grains to coarse size common, phosphatic claystone nodules very rare. Contains fish bones and scales rare. Framework, 15 percent quartz, 3 percent feldspar, 33 percent phosphatic pellets, and 1 percent chlorite(?); matrix, 5 percent clay minerals, 1 percent carbonate, 35 percent opal, and 7 percent iron oxide. Quartz, albite, apatite, orthoclase, opal-CT, and montmorillonite were detected by X-ray diffraction analysis. Specific gravity, 1.80. Sample 100-35 from middle of unit.

33. Phosphorite, dark-grayish-orange (10YR6/4), massive to faintly bedded, moderately indurated to friable, angular to subrounded grains, poorly sorted, floating grains to coarse size abundant, phosphatic pellets are well sorted (in the 0.1-0.2 $\mathrm{mm}$ range). Contains fish bones rare. Framework, 15 percent quartz, 4 percent feldspar, 1 percent carbonate fragments, and 57 percent phosphatic pellets and nodules; matrix, 19 percent clay minerals, 2 percent carbonate, 1 percent apatite, and 1 percent iron oxide. Apatite, quartz, albite, orthoclase, and a trace of calcite and montmorillonite were detected by $\mathrm{X}$-ray diffraction analysis. Specific gravity, 2.49 . Sample 100-36 from middle of unit.

32. Mudstone, phosphatic, pinkishgray (5YR8/1) to light-gray (N7) with grayish-orange (10YR7/4) stains, massive to faintly bedded, indurated, slightly burrowed, subangular to subrounded grains, poorly sorted, floating grains to coarse size abundant, phosphatic pellets are well sorted (in the 0.1 $0.2 \mathrm{~mm}$ range), pellets rarely concentrated in lenses, locally pellets are light-gray (N8) and appear leached. Contains fish scales rare. Framework, 20 percent quartz, 6 percent feldspar, 
Upper Miocene-Continued

Santa Margarita Formation-Continued

Upper phosphatic mudstone member-Continued Unit No.

$$
\text { FI In } M \quad C m
$$

and 27 percent phosphatic pellets; matrix, 30 percent clay minerals and 17 percent opal. Basal $1 \mathrm{ft}(0.3 \mathrm{~m})$ contains as much as 40 percent pellets. Quartz, albite, orthoclase, opalCT, and apatite were detected by X-ray diffraction analysis. Specific gravity, 1.79. Sample 100-37 from middle of unit.

31. Mudstone, siliceous, slightly phosphatic, very light gray (N8) with light-olive-brown (5Y5/6) stains, massive to faintly bedded, indurated, angular to subangulär grains, medium-sorted, floating grains to medium size rare, phosphatic claystone grains very rare. Contains fish scales and diatom and pelecypod molds rare. Framework, 22 percent quartz, 6 percent feldspar, and 4 percent phosphatic pellets; matrix, 17 percent clay minerals, 1 percent carbonate, 45 percent opal, and 5 percent iron oxide. Phosphorite bed 1 $\mathrm{ft}(0.3 \mathrm{~m})$ thick contains 70 percent pellets $2 \mathrm{ft}(0.6 \mathrm{~m})$ from top of unit. Opal-CT, quartz, albite, orthoclase, montmorillonite, and illite were detected by $\mathrm{X}$-ray diffraction analysis. Specific gravity, 1.72. Sample 100-38 from middle of unit. Correlation unit S4 at base of unit.

30. Mudstone, moderately phosphatic, yellowish-gray $(5 Y 8 / 1)$ with light-brown (5YR5/6) stains, nonbedded to faintly bedded, moderately indurated, subangular to rounded grains, poorly sorted, floating grains to coarse size abundant. Contains sponge spicules, fish scales and bones, and burrows rare. Framework, 30 percent quartz, 10 percent feldspar, 2 percent carbonate fragments, and 12 percent phosphatic pellets; matrix, 38 percent clay minerals, 6 percent apatite, and 2 percent iron oxide. Locally contains 20-70 percent pellets. Quartz, albite, apatite, orthoclase, and a trace of opalCT were detected by $\mathrm{X}$-ray diffraction analysis. Specific gravity, 2.20. Sample 100-39 from middle of unit.

29. Mudstone, siliceous, slightly
Upper Miocene-Continued

Santa Margarita Formation-Continued

Upper phosphatic mudstone member-Continued Unit No.

\section{Thickness}

FI In $M \quad C m$

phosphatic, very light gray

(N8) with light-brown

(5YR5/6) stains, massive, indurated, angular to subrounded grains, mediumsorted, floating grains to fine size very rare. Contains both phosphatic pellets and molds of pellets; fish scales rare. Framework, 12 percent quartz, 1 percent feldspar, and 3 percent phosphatic pellets; matrix, 18 percent clay minerals, 2 percent carbonate, 56 percent opal, and 8 percent iron oxide. Quartz, albite, orthoclase, opalCT, and a trace of apatite, illite, and montmorillonite were detected by $\mathrm{X}$-ray diffraction analysis. Specific gravity, 1.89. Sample 100-40 from middle of unit.

28. Siltstone, moderately phosphatic, sandy (very fine to finegrained), very light gray (N8) with light-olive-brown (5Y5/6) and light-brown (5YR5/6) stains, faintly laminated, indurated, angular to subangular grains, poorly sorted, floating grains to coarse size common; light-grayish-pink (5YR8/1) phosphatic claystone pellets and nodules rare. Contains fish bones rare. Framework, 26 percent quartz, 7 percent feldspar, 15 percent phosphatic pellets and nodules, and 1 percent glauconite; matrix, 38 percent clay minerals, 5 percent apatite, 6 percent iron oxide, and 2 percent carbonate. Quartz, albite, orthoclase, apatite, and opal-CT were detected by $\mathrm{X}$ ray diffraction analysis. Specific gravity, 1.96. Sample 10041 from middle of unit. Plate $6 \mathrm{~B}$ from unit.

27. Siltstone, moderately phosphatic, sandy (very fine to finegrained), very light to lightgray (N8-N7) with light-olivebrown (5Y5/6) stains, massive indurated, angular to subangular grains, poorly sorted, floating grains to medium size abundant, grayish-pink (5R8/2) phosphatic claystone nodules common, scattered molds of pellets, fish bones and scales, and mammal(?) bones rare. Framework, 34 percent quartz, 5 percent feldspar, 12 percent 
Upper Miocene-Continued

Santa Margarita Formation-Continued

Upper phosphatic mudstone member-Continued Unit No.

$$
\text { Ft In } \quad M \quad C m
$$

phosphatic pellets and nodules,

3 percent accessory minerals, and 3 percent heavy minerals; matrix, 27 percent clay minerals, 12 percent opal, and 4 percent iron oxide. Opal-CT, quartz, albite, apatite, and orthoclase were detected by $\mathrm{X}$ ray diffraction analysis. Specific gravity, 2.20. Sample $100-42$ from middle of unit.

26. Mudstone, moderately phosphatic, dolomitic, yellowish gray $(5 Y 8 / 1)$ with moderatebrown (5YR4/4) stains, massive, moderately indurated, slightly burrowed, subangular to subrounded grains, poorly sorted, floating grains to coarse size rare, locally phosphatic pellets concentrated in lenses and burrows, phosphatic claystone nodules rare, fish scales common, fish bones and pelecypod molds rare.

Framework, 8 percent quartz, 2 percent feldspar, 10 percent phosphatic pellets, and 1 percent heavy minerals; matrix, 17 percent clay minerals, 29 percent dolomite, 28 percent opal, and 5 percent iron oxide. Quartz, albite, apatite, orthoclase, opal-CT, dolomite, and a trace of montmorillonite were detected by X-ray diffraction analysis. Specific gravity, 1.92. Sample $100-43$ from middle of unit.

25. Phosphorite, calcareous, silty, dark-grayish-orange (10YR6/4), lenses to faintly laminated, moderately indurated to weakly indurated, subangular to subrounded grains, medium-sorted, floating grains to medium-size rare; phosphatic nodules that average $0.2 \mathrm{~mm}$ in diameter; fish bones and pelecypod molds rare. Framework, 8 percent quartz, 7 percent feldspar, and 59 percent phosphatic pellets and nodules; matrix, 11 percent clay minerals, 11 percent carbonate, and 4 percent iron oxide. Apatite, quartz, calcite, albite, and a trace of illite were detected by $\mathrm{X}$-ray diffraction analysis. Specific gravity, 2.51 . Sample 100-44 from middle of unit. Correlation unit P4.
Upper Miocene-Continued

Santa Margarita Formation-Continued

Upper phosphatic mudstone member-Continued Unit No.

\section{Thickness}

lowish-gray (5Y8/1) with very

dark yellowish orange

(10YR5/6) stains, massive to

faintly laminated, indurated, angular to subangular grains, medium-sorted, floating grains to fine size rare. Contains fish scales common, pelecypod molds rare. Framework, 6 percent quartz, 1 percent feldspar, and 2 percent phosphatic pellets; matrix, 64 percent dolomite, 2 percent apatite, 20 percent opal, and 5 percent iron oxide. Dolomite, quartz, albite, opal-CT, orthoclase, and montmorillonite were detected by $\mathrm{X}$-ray diffraction analysis. Specific gravity, 1.77. Sample $100-45$ from middle of unit.

Ft In $M \quad C m$

3. Sandstone, moderately phosphatic, fine-grained, silty, yellowish-gray (5Y7/2), massive, weakly indurated, angular to subrounded grains, mediumsorted, floating grains to coarse size rare. Contains pelecypod molds rare. Framework, 37 percent quartz, 12 percent feldspar, and 19 percent phosphatic pellets; matrix, 16 percent clay minerals, 7 percent carbonate, and 11 percent iron oxide. Quartz, albite, orthoclase, apatite, and illite were detected by $\mathrm{X}$-ray diffraction analysis. Specific gravity not determined. Sample 100-46 from middle of unit.

22. Mudstone, moderately phosphatic, siliceous, silty, lightgray (N7) to yellowish-gray (5Y8/1) with moderate-brown (5YR4/6) stains, faintly laminated, moderately indurated, angular to rounded grains, poorly sorted, floating grains to medium size rare. Contains small $(1.0-2.0 \mathrm{~cm})$ intraclasts of siliceous mudstone; fish scales and bones rare, one mammal(?) bone fragment. Framework, 15 percent quartz, 2 percent feldspar, and 15 percent phosphatic pellets; matrix, 26 percent clay minerals, 2 percent carbonate, 1 percent apatite, 30 percent opal, and 9 percent iron oxide. Quartz, albite, orthoclase, apatite, and opal-CT were detected by Xray diffraction analysis. Specific gravity, 2.25. Sample 
Upper Miocene-Continued

Santa Margarita Formation-Continued

Upper phosphatic mudstone member-Continued Unit No.

100-47 from middle of unit.

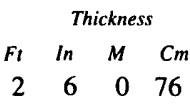

21. Mudstone, siliceous, ferruginous, light-olive gray $(5 \mathrm{Y} 6 / 1)$ to light-gray (N7) with lightolive-brown (5Y5/6) stains, massive to faintly laminated, indurated, angular to subrounded grains, poorly sorted, floating grains to coarse size rare. Contains fish scales rare. Framework, 16 percent quartz, 3 percent feldspar, and 1 percent carbonate fragments; matrix, 29 percent clay minerals, and 51 percent iron oxide. Iron oxides include less than 10 percent pellets that probably were phosphatic originally. Lower $4 \mathrm{ft}(1.22 \mathrm{~m})$ contains phosphorite lenses with as much as 60 percent pellets. A $1-\mathrm{ft}(0.3-\mathrm{m})$ bentonite bed is 1 $\mathrm{ft}(0.3 \mathrm{~m})$ from base of unit. Quartz, albite, orthoclase, illite, and montmorillonite were detected by $\mathrm{X}$-ray diffraction analysis. Specific gravity, 1.79. Sample 100-48 from middle of unit.

20. Mudstone, slightly phosphatic, siliceous, silty, dark-pinkishgray (5YR7/1) with moderatebrown (5YR4/4) stains, massive to faintly laminated, indurated, angular to subrounded grains, poorly sorted, floating grains to medium size very rare; locally concentrated phosphatic pellets-some are partly leached. Contains fish scales, rare. Framework, 9 percent quartz, and 5 percent phosphatic pellets; matrix, 19 percent clay minerals, 60 percent opal, and 7 percent iron oxide. Basal $1 \mathrm{ft}(0.3 \mathrm{~m})$ contains as much as 40 percent pellets. Quartz, albite, opal-CT, orthoclase, and a trace of apatite were detected by X-ray diffraction analysis. Specific gravity, 1.87. Sample 100-49 from middle of unit.

19. Phosphorite, sandy (very fine grained), light-brownish-gray (5YR6/1) to light-olive-gray (5YR6/1) with light-brown (5YR5/6) stains, faint muddy laminations, indurated, angular to subrounded grains, mediumsorted, floating grains to coarse size very rare. Contains fish scales rare. Framework, 13 per-
Upper Miocene-Continued

Santa Margarita Formation-Continued

Upper phosphatic mudstone member-Continued Unit No.

$$
\text { Ft In } \quad M \quad C m
$$

cent quartz, 2 percent feldspar,

1 percent carbonate fragments, and 50 percent phosphatic pellets and nodules; matrix, 26 percent clay minerals, 5 percent opal, and 3 percent iron oxide. Quartz, apatite, albite, opal-CT, orthoclase, and a trace of illite were detected by $\mathrm{X}$-ray diffraction analysis. Specific gravity, 2.15. Sample

-100-50 from middle of unit.

18. Bentonite, muddy, grayish-yellow (5Y8/4) to yellowish-gray (5Y7/2), massive, moderately indurated. Montmorillonite, gypsum, quartz, albite, and orthoclase were detected by Xray diffraction analysis. Specific gravity not determined. Sample 100-51 from middle of unit.

$\begin{array}{llll}1 & 10 & 0 & 56\end{array}$

17. Bentonite, silty, light-olive-gray (5Y5/2) to dusky-yellow (5Y6/4), massive, friable, plastic when wet. Montmorillonite, gypsum, and a trace of quartz, albite, and anhydrite(?) were detected by $\mathrm{X}$-ray diffraction analysis. Specific gravity not determined. Sample 100-52 from middle of unit.

16. Siltstone, slightly phosphatic, sandy (very fine to finegrained), yellowish-gray (5Y8/1) with moderate-brown (5YR4/4) and black (N1) stains, massive to faintly laminated, indurated, slightly burrowed, subangular to rounded grains, mediumsorted, floating grains to fine size very rare; phosphatic claystone nodules very rare; fish scales and pelecypod molds rare. Framework, 29 percent quartz, 9 percent feldspar, 1 percent chert, 6 percent phosphatic pellets, and 1 percent heavy minerals; matrix, 31 percent clay minerals, 10 percent dolomite, 10 percent opal, and 3 percent iron oxide. Quartz, dolomite, opal-CT, albite, orthoclase, and apatite were detected by $\mathrm{X}$-ray diffraction analysis. Specific gravity, 2.40 . Sample 100-53 from middle of unit.

15. Sandstone, moderately phosphatic, very fine grained, very light gray (N8) to yellowishgray $(5 Y 8 / 1)$ with grayish- 
Upper Miocene-Continued

Santa Margarita Formation-Continued

Upper phosphatic mudstone member-Continued Unit No.

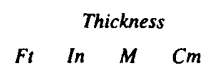

orange (10YR7/4) stains, massive, moderately indurated to weakly indurated, subangular to subrounded grains, well sorted, floating grains to medium-size very rare; pelecypod molds abundant. Framework, 35 percent quartz, 11 percent feldspar, 4 percent chert, 15 percent phosphatic pellets, and 2 percent heavy minerals; matrix, 26 percent clay minerals, 6 percent carbonate, and 1 percent iron oxide. Quartz, calcite, albite, orthoclase, apatite, and illite were detected by X-ray diffraction analysis. Specific gravity, 2.44. Sample 100-54 from middle of unit.

14. Siltstone, phosphatic, sandy (very fine to fine-grained), lightolive-gray $(5 Y 6 / 1)$ to yellowish-gray (5Y8/1) with moderate-brown (5YR4/4) stains, massive, indurated, angular to subrounded grains, poorly sorted, floating grains to medium size very rare; phosphatic claystone nodules very rare; fish scales rare. Framework, 27 percent quartz, 9 percent feldspar, and 25 percent phosphatic pellets; matrix, 27 percent clay minerals, 4 percent apatite, 4 percent opal, and 4 percent iron oxide. Local pellet concentrations for unit range from 15 to 60 percent. Quartz, albite, orthoclase, apatite, and opal-CT were detected by $\mathrm{X}$-ray diffraction analysis. Specific gravity, 2.22. Sample 100-55 from middle of unit.

13. Siltstone, bentonitic, siliceous, light-gray (N7), massive, weakly indurated, very angular to angular grains, mediumsorted, floating grains to fine size very rare. Contains mudstone intraclasts to $3 \mathrm{~cm}$. Framework, 31 percent quartz, 8 percent feldspar, and 1 percent chlorite; matrix, 25 percent clay minerals, 3 percent apatite, 25 percent opal, and 7 percent iron oxide. Quartz, montmorillonite albite, and orthoclase were detected by $\mathrm{X}$-ray diffraction analysis. Specific gravity, 2.07 . Sample 100-56 from middle of unit.
Upper Miocene-Continued

Santa Margarita Formation-Continued

Upper phosphatic mudstone member-Continued Unit No.

$$
\text { Ft In } M \quad \mathrm{Cm}
$$

12. Siltstone, moderately phosphatic, light- to very light gray (N7N8) with light-olive-brown (5Y5/6) stains, massive, indurated, angular to subrounded grains, medium-sorted, floating grains to medium size very rare; phosphatic claystone nodules very rare; disc-shaped phosphatized diatoms (cores of some pellets are the diatom genus Coscinodiscus) abundant; fish scales rare. Quartz, opal-CT, albite, orthoclase, and apatite were detected by X-ray diffraction analysis. Specific gravity, 1.87. Sample 100-57 from middle of unit. Plate $6 \mathrm{C}$ from unit.

11. Mudstone, slightly to nonphosphatic, yellowish-gray (5Y8/1) with moderate-brown (5YR4/4) stains, massive, weakly indurated, angular to subrounded grains, poorly sorted. Unit poorly exposedno sample.

10. Mudstone, silty and sandy (very fine grained), yellowish-gray (5Y8/1) to pinkish-gray (5YR8/1) with light-brown (5YR5/6) stains, massive to faintly laminated, indurated, very angular to subangular grains, medium-sorted; scattered phosphatic pellets rare; fish scales rare. Framework, 5 percent quartz and 1 percent feldspar; matrix, 13 percent clay minerals, 75 percent opal, and 6 percent iron oxide. Opal$\mathrm{CT}$, quartz, albite, orthoclase, and a trace of illite were detected by $\mathrm{X}$-ray diffraction analysis. Specific gravity, 2.04. Sample 100-58 from middle of unit.

9. Siltstone, moderately phosphatic, sandy (very fine to finegrained), light-gray (N7) to yellowish-gray (5Y7/2) with darkyellowish-orange (10YR6/6) stains, massive to faintly bedded, moderately indurated, swirled mudstone laminations rare, slightly burrowed, angular to rounded grains, poorly sorted, floating grains to coarse size common; phosphatic pellets decrease in number from base upward, pellets concentrated in burrows, phosphatic claystone nodules rare; fish 
Upper Miocene-Continued

Santa Margarita Formation-Continued

Upper phosphatic mudstone member-Continued Unit No.

Thickness

Ft In $\quad M \quad C m$

bones rare, scales and pelecypod molds rare. Framework, 23 percent quartz, 11 percent feldspar, 2 percent carbonate fragments, and 17 percent phosphatic pellets; matrix, 27 percent clay minerals, 8 percent apatite(?), 8 percent opal, and 4 percent iron oxide. Quartz, albite, orthoclase, opal$\mathrm{CT}$, and apatite were detected by X-ray diffraction analysis. Specific gravity, 2.50. Sample $100-59$ from middle of unit.

8. Sandstone, slightly phosphatic, very fine grained, very calcareous, grayish-orange (10YR7/4), massive, weakly indurated to indurated, angular to subrounded grains, poorly sorted, floating grains to granule size, and scattered small phosphatic claystone nodules and chert pebbles common. Fish bones and megafossils including many phosphatized casts of pelecypods and gastropods common. Very irregular base, very distinctive unit. Framework, 17 percent quartz, 4 percent feldspar, 1 percent carbonate fragments, 9 percent phosphatic pellets, and 2 percent heavy minerals; matrix, 5 percent iron oxide, and 62 percent carbonate cement. Quartz, calcite, albite, apatite, orthoclase, and dolomite were detected by $\mathrm{X}$-ray diffraction analysis. Specific gravity, 2.46. Sample 100-60 from middle of unit.

Siltstone, slightly phosphatic, clayey, sandy (very fine to medium-grained), bentonitic, yellowish-gray (5Y8/1) to darkyellowish-gray $(5 Y 7 / 1)$ with very dark yellowish orange (10YR5/6) stains, massive, indurated, angular to subrounded grains, poorly sorted, floating grains to coarse size common. Most pellets average $0.1 \mathrm{~mm}$, but some are greater than $1.0 \mathrm{~mm}$ in diameter. Fish vertebrae (very rare), ribs, and scales rare; concentrated in burrows. Framework, 35 percent quartz, 6 percent feldspar, 1 percent carbonate fragments, 7 percent phosphatic pellets, and 1 percent pyrite(?); matrix, 29 percent clay minerals, 1
Upper Miocene-Continued

Santa Margarita Formation-Continued

Upper phosphatic mudstone member-Continued Unit No.

Thickness Ft In $\mathrm{M} \mathrm{Cm}$

percent carbonate, 4 percent apatite, 10 percent opal, and 6 percent iron oxide. Quartz, opal-CT, albite, and orthoclase were detected by $\mathrm{X}$-ray diffraction analysis. Specific gravity, 1.78. Sample 100-61 from middle of unit.

$\begin{array}{llll}15 & 0 & 4 & 57\end{array}$

6. Sandstone, phosphatic, very fine to fine-grained, silty, calcareous, grayish-orange (10YR7/4), massive, weakly indurated to indurated, subangular to subrounded grains, poorly sorted, floating grains to coarse size; small nodules plentiful. Fish bones and pelecypod molds as much as $5 \mathrm{~cm}$ in diameter rare. Unit similar to unit 8. Framework, 21 percent quartz, 5 percent feldspar, and 27 percent phosphatic pellets and nodules; matrix, 3 percent clay minerals, 38 percent carbonate, and 6 percent iron oxide. Quartz, albite, dolomite, orthoclase, calcite, and apatite were detected by X-ray diffraction analysis. Specific gravity, 2.47. Sample 100-62 from middle of unit.

5. Sandstone, slightly phosphatic, very fine to fine-grained, silty, pale-grayish-orange (10YR8/4) with moderate-brown (5YR4/4) and black (N1) stains, massive, indurated, very angular to subangular grains, medium-sorted, floating grains to coarse size rare. Pelecypod molds and casts as much as $6 \mathrm{~cm}$ in diameter rare, broken fish bones and scales rare, burrows very rare. Framework, 30 percent quartz, 12 percent feldspar, and 4 percent phosphatic pellets and nodules; matrix, 28 percent clay minerals, 4 percent dolomite, 15 percent apatite(?), and 7 percent iron oxide. Quartz, dolomite, albite, and orthoclase were detected by $\mathrm{X}$-ray diffraction analysis. Specific gravity, 2.24. Sample 100-63 from middle of unit.

4. Claystone, siliceous, silty, bentonitic in part, yellowish-gray (5Y8/1) with light-brown (5YR5/6) stains, massive, indurated, angular to subrounded grains, poorly sorted. Sponge spicules common and 
Upper Miocene-Continued

Santa Margarita Formation-Continued

Upper phosphatic mudstone member-Continued Unit No.

fish scales rare. Framework, 10 percent quartz, 1 percent feldspar, and 2 percent heavy minerals; matrix, 73 percent clay minerals, 7 percent opal, and 7 percent iron oxide. Montmorillonite, opal-CT, quartz, albite, and orthoclase were detected by $\mathrm{X}$-ray diffraction analysis. Specific gravity not determined. Sample 100-64 from middle of unit.

3. Siltstone, clayey, sandy (very fine to fine-grained), siliceous, very light to light-gray (N8-N7) with light-olive-brown (5Y6/6) and very dark yellowish orange (10YR5/6) stains, massive, moderately indurated, angular to subangular grains, mediumsorted, floating grains to coarse size very rare. Contains phosphatic pellets very rare, fish bones and scales rare, slightly burrowed. Framework, 35 percent quartz, 11 percent feldspar, 1 percent carbonate fragments, and 2 percent phosphatic pellets; matrix, 1 percent chlorite, 34 percent clay minerals, 4 percent carbonate, and 4 percent iron oxide. Abundant quartz, albite, orthoclase, and some opal-CT were detected by X-ray diffraction analysis. Specific gravity, 2.26. Sample 100-65 from middle of unit.

2. Claystone, silty, bentonitic in part, dusky-yellow (5Y6/4) with some very light brown tion analysis. Specific gravity
Upper Miocene-Continued

Santa Margarita Formation-Continued

Lower sandstone member-Continued Unit No.

$$
\text { Ft In } \quad M \quad C m
$$

slightly calcareous, grains medium- to well-sorted; floating grains as large as coarse size, rare. Nonphosphatic except for rare fish bones and scales. Pelecypods shells rare. Medium- to coarse-grained sandstone makes up most of the unit. Slightly to very calcareous, nonphosphatic, very pale orange (10YR8/2) to yellowish-orange (10YR7/6); massive, moderately indurated to friable; very fine grained sand to pebbles, poorly sorted. Pectens and other mollusks very abundant; pelecypod shells and shell fragments including oysters, Ostrea titan. Abundant quartz, albite, and orthoclase were detected by Xray diffraction analysis. Specific gravity not determined. Sample 100-67 from top of unit.

Not Measured

\section{Trench 294}

(Measured by H. D. Gower, 1964; E and F numbered samples described petrographically by $\mathrm{T}$. L. Vercoutere)

LOCATION: NW1/4SE1/4 sec. 6, T. 9 N., R. 26 W. (S.B.B.\&M) in the New Cuyama, California Quadrangle.

ATTITUDE OF BEDDING: Approximately N $50^{\circ} \mathrm{W}$. Stratigraphic units 164-152 are in a road cut northwest of trench 294. A pipeline trench, south of trench 294, contains units 107 to 164 .

\section{Upper Miocene:}

Santa Margarita Formation:

Upper sandstone member: Unit No.

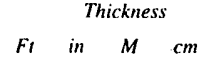
(5YR7/4) stains, massive, weakly indurated, angular to subrounded grains, mediumsorted, floating grains to fine size rare. Montmorillonite, quartz, albite, and orthoclase were detected by X-ray diffracnot determined. Sample 100-66 from middle of unit.

Total thickness of upper phosphatic mudstone member

164. Sandstone, fine-grained, silty, micaceous, grayish-orange, weathers white, massive, friable, poorly sorted. Contains large biotite(?) flakes. Gradational(?) base. Thickness approximate

163. Siltstone, sandy, slightly shaly. Most of unit fractures into small, angular fragments, friable. Two-inch $(5-\mathrm{cm})$ calcite vein at base. Thickness approximate

162. Sandstone, very fine grained, light-gray to very pale orange. Clams, very dark brown, phosphatic, very small, very abundant. Unit appears highly burrowed; large burrow holes penetrate underlying siltstone. Irregular base.

Santa Margarita Formation:

Lower sandstone member:

1. Sandstone, very fine to finegrained, and medium- to coarse-grained. Fine-grained sandstone: noncalcareous to 
Upper Miocene-Continued

Santa Margarita Formation-Continued

Upper sandstone member-Continued Unit No.

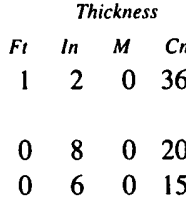

161. Siltstone

160. Bentonite and highly bentonitic siltstone

159. Siltstone

158. Sandstone, very fine grained, light-gray to very pale orange. Phosphatic pellets rare, darkbrown, coarse to very coarse, local. Thickness approximate

157. Siltstone, sandy, olive-gray to olive-brown

156. Sandstone, very fine grained, light-gray; irregular thickness

155. Siltstone, olive-gray, massive; weathers into small angular fragments

154. Sandstone, very fine grained, and sandy siltstone; some crossbedding

153. Sandstone, very fine grained, thin . bedded [2-in. $(5-\mathrm{cm})$ beds]

152. Sandstone, very fine grained, massive. Appears clam-bored in many places; lower $1 \mathrm{ft}$ contains large internal molds of clams. Phosphatic pellets, coarse-grained, 5 percent very dark brown, in lower part. Top half not closely examined

151. Bentonite and bentonitic siltstone

150. Siltstone, olive gray; about 5 percent coarse phosphatic pellets in lower $2 \mathrm{ft}(61 \mathrm{~cm})$

$\begin{array}{llll}20 & 0 & 6 & 10\end{array}$

$\begin{array}{llll}0 & 7 & 0 & 18\end{array}$

$12 \quad 0 \quad 3 \quad 66$

149. Sandstone very fine grained, silty; 7 percent phosphatic pellets

148. Siltstone, olive gray; about 5 percent coarse very dark brown phosphatic pellets

$\begin{array}{llll}1 & 6 & 0 & 46\end{array}$

$\begin{array}{llll}8 & 0 & 2 & 44\end{array}$

147. Sandstone, very fine grained; 5 percent phosphatic pellets in upper half, less at base; abundant fossils at base

$\begin{array}{llll}4 & 0 & 1 & 22\end{array}$

Total measured thickness of upper sandstone member:

Upper Miocene:

Santa Margarita Formation-Continued

Upper phosphatic mudstone member: Unit No.

146. Siltstone and sandy siltstone; minor phosphate

145. Covered interval, weakly indurated; probably mudstone

144. Sandstone, very fine grained, poorly sorted, indurated; some reddish-brown phosphatic nodules at top as large as 1 in. ( 3 $\mathrm{cm}$ )

143. Siltstone, weakly indurated

142. Siltstone, siliceous, indurated

141. Siltstone, weakly indurated; 2 -in.

Upper Miocene-Continued

Santa Margarita Formation-Continued

Upper phosphatic mudstone member-Continued Unit No.

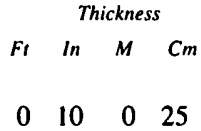

(5-cm) zone of indurated, $\mathrm{si}$ liceous siltstone near base

$\begin{array}{llll}0 & 10 & 0 & 25\end{array}$

140. Sandstone, very fine grained, siliceous, indurated; some smallscale, irregular, broken beds; irregular base

$\begin{array}{llll}1 & 0 & 0 & 30\end{array}$

139. Siltstone, very thin bedded; weakly indurated

11033

138. Limestone, fossiliferous, indurated

$\begin{array}{llll}1 & 0 & 0 & 30\end{array}$

137. Siltstone, calcareous, fossiliferous, very thin bedded; most beds 2 in. $(5 \mathrm{~cm})$ or less

136. Siltstone, olive- to light-gray, moderately indurated; contains several bentonite beds, upper part may be slightly bentonitic; weathering patterns suggest possibly very thinly bedded

135. Sandstone, very fine grained, slightly phosphatic, light-gray

134. Sandstone, very fine grained, brown to brownish-gray; about 5 percent phosphatic pellets

133. Sandstone, very fine grained, pale-orange-brown; some crossbedding visible, may be foreset beds, dipping northward; phosphatic pellets, darkbrown, fine-grained, locally concentrated, pellets average 20 percent in unit; clam burrows at base; very irregular base

132. Sandstone, very fine grained, and sandy siltstone; some phosphatic pellets; lower part may show foreset beds, dipping north

131. Siltstone, siliceous, indurated

130. Siltstone, siliceous, moderately indurated

$\begin{array}{llll}3 & 6 & 1 & 7\end{array}$

$\begin{array}{llll}0 & 5 & 0 & 13\end{array}$

$\begin{array}{llll}0 & 5 & 0 & 13\end{array}$

129. Siltstone, siliceous, indurated; some light-gray phosphatic pellets

$\begin{array}{llll}1 & 10 & 0 & 56\end{array}$

128. Siltstone, moderately indurated

127. Limestone, leached in places

126. Siltstone, somewhat siliceous

$\begin{array}{llll}1 & 0 & 0 & 30\end{array}$

$\begin{array}{llll}0 & 6 & 0 & 15\end{array}$

125. Sandstone, very fine grained, and sandy siltstone, orange-brown; possibly crossbedded, in part; 15 percent phosphatic pellets; large clams at base; very irregular base

$\begin{array}{llll}10 & 0 & 3 & 5\end{array}$

124. Siltstone

123. Mudstone, light-gray, moderately phosphatic, very sandy, partly grain-supported. Sand, fine grained; grains subangular to subrounded, randomly oriented, altered grain boundaries common; incipient calcitization 
Upper Miocene-Continued

Santa Margarita Formation-Continued

Upper phosphatic mudstone member-Continued Unit No.

of grains rare; floating grains to Ft In $\quad M \quad C m$ very coarse size rare. Framework, 29 percent quartz, 13 percent feldspar, and 10 percent phosphate; matrix, 46 percent clay minerals and 2 percent iron oxide; accessory minerals include hematite, magnetite, chlorite, muscovite, and zircon. Phosphatic framework consists of 38 percent pellets with noncentered grain inclusions and 38 percent pellets with centered grain inclusions of quartz, diatom fragments, feldspar, very rare zircon, 17 percent structureless pellets, 5 percent compound pellets, and 2 percent shell and pebble fragments. Pellets are 'regular to slightly irregular spheroids between $0.10 \mathrm{~mm}$ and $0.30 \mathrm{~mm}$ in diameter (average $0.19 \mathrm{~mm}$ ), with moderately sharp to slightly fuzzy boundaries and peripherally deformed when in contact with other pellets. Hematite staining tends to be in and around pellets. Hematite concentrations form hematite-rich bands. Some crossbedding in upper part of unit; abundant burrows at and below base. Very irregular base. Sample F1208-39 from unit

122. Siltstone; locally abundant phosphatic pellets

121. Sandstone, silty, and sandy siltstone, light gray; about 5-10 percent light-gray phosphatic pellets

120. Mudstone, very sandy, moderately phosphatic, partly grain supported, orangish-brown. Sand, fine-grained, subrounded to subangular, medium-sorted, randomly oriented. Framework, 26 percent quartz, 13 percent feldspar, 17 percent phosphate; matrix, 34 percent clay minerals (matrix), 4 percent apatite (cement), and 4 percent iron oxide; accessory minerals include chlorite, hematite, magnetite, and calcite. Phosphatic framework, 6 percent pellets with noncentered inclusions, and 53 percent pellets with centered inclusions of quartz, feldspar, and diatom fragments, 24 percent structureless pellets, 6 percent
Upper Miocene-Continued

Santa Margarita Formation-Continued

Upper phosphatic mudstone member-Continued Unit No.

nodules with grain inclusions as large as $0.85 \mathrm{~mm}$, and 12 percent fish-bone and shell fragments. Pellets, regular to slightly irregular spheroids, range from $0.05 \mathrm{~mm}$ to 0.30 $\mathrm{mm}$ in diameter, average diameter $0.11 \mathrm{~mm}$; predominantly sharp boundaries, slightly deformed peripherally at contacts with other grains and pellets; most stained with iron oxide, especially if nucleus is a diatom. Contains fish bones and shell fragments as large as $1 \mathrm{~mm}$; diatoms. Sample F1208-38

Ft In $\quad M \quad C m$

119. Siltstone; bentonite bed 5 in. (13 $\mathrm{cm})$ above base

118. Mudstone, phosphatic, pelletal, sandy, silty, orangish-brown. Grains, subangular to subrounded; randomly oriented, poorly sorted; floating grains as large as coarse size. Framework, 14 percent quartz, 8 percent feldspar, 36 percent phosphate; matrix, 25 percent clay minerals, 7 percent apatite cement, and 9 percent iron oxide; accessory minerals, 1 percent, include chlorite, zircon, glauconite, and magnetite. Phosphatic framework, 17 percent pellets with noncentered inclusions and 28 percent pellets with centered inclusions of quartz, feldspar, diatom fragments, and hematite, 36 percent structureless pellets, 6 percent compound pellets, 6 percent nodules with and without grain inclusions, 3 percent fish bones, and 6 percent shell fragments as large as $1 \mathrm{~mm}$. Pellets, regular to irregular spheroids, range from 0.08 $\mathrm{mm}$ and $0.70 \mathrm{~mm}$ in diameter (average $0.15 \mathrm{~mm}$ ); sharp rims, partially replaced with calcite rare; most stained by hematite. Hematite staining and replacement in pellets largely confined to the interior of pellets; degree of staining varies from barely visible to completely opaque. Sample F1208-37 from unit.

117. Bentonite Figure 6D from unit

116. Siltstone

115. Sandstone, very fine grained, silty, slightly phosphatic

114. Siltstone 
Upper Miocene-Continued

Santa Margarita Formation-Continued

Upper phosphatic mudstone member-Continued Unit No.

113. Siltstone, very phosphatic, pelletal, muddy, brown, poorly sorted, partially framework supported. Grains, subangular to subrounded, randomly oriented, boundaries commonly altered. Framework, 16 percent quartz, 9 percent feldspar, 2 percent chert fragments, and 40 percent phosphatic; matrix, 28 percent clay minerals, 5 percent iron oxide; accessory minerals include hematite, magnetite, chlorite, muscovite, and zircon. Phosphatic framework, 29 percent pellets with noncentered inclusions and 22 percent pellets with centered inclusions of quartz, diatom fragments, feldspar, and hematite, 27 percent structureless pellets, 15 percent compound pellets, 3 percent nodules with inclusions, 4 percent shell fragments. Pellets, spheroids range from $0.04 \mathrm{~mm}$ and $0.70 \mathrm{~mm}$ in diameter, average diameter $0.16 \mathrm{~mm}$; very sharp to slightly fuzzy boundaries, periphery commonly deformed slightly at contacts with grains or other pellets, and diatom fragments commonly replaced partially by hematite. X-ray diffraction analysis indicates quartz, opal$\mathrm{CT}$ and a minor component of illite. Correlation unit P1. Samples F1208-36 and P1-294 from unit

112. Siltstone, sandy; 15 percent phosphatic pellets

111. Bentonite

110. Siltstone

109. Siltstone; covered

108. Sandstone, very fine grained

107. Siltstone, covered

106. Limestone, cream-colored, indurated; highly fossiliferous

105. Sandstone, very fine grained, silty; poorly exposed

104. Siltstone, sandy, olive- to lightgray

103. Sandstone, very fine grained, silty; moderately indurated; highly fossiliferous

102. Siltstone, bentonitic, olive-gray

101. Siltstone, sandy, olive-gray; small 'megafossils abundant

100. Bentonite

99. Siltstone, bentonitic

98. Siltstone, siliceous

97. Bentonite and bentonitic siltstone

$\begin{array}{llll}2 & 0 & 0 & 61 \\ 0 & 5 & 0 & 13\end{array}$

$\begin{array}{llll}0 & 2 & 0 & 5\end{array}$

$\begin{array}{llll}3 & 10 & 1 & 17\end{array}$

$\begin{array}{llll}3 & 0 & 0 & 91\end{array}$

$\begin{array}{llll}0 & 1 & 0 & 3\end{array}$

$\begin{array}{llll}5 & 6 & 1 & 68\end{array}$

$\begin{array}{lll}0 & 6 & 0\end{array}$

$\begin{array}{llll}0 & 6 & 0 & 15\end{array}$

I 6046

$\begin{array}{llll}0 & 5 & 0 & 13\end{array}$

$\begin{array}{llll}0 & 6 & 0 & 15\end{array}$

$\begin{array}{llll}1 & 11 & 0 & 58\end{array}$

$\begin{array}{llll}0 & 6 & 0 & 15\end{array}$

$\begin{array}{llll}0 & 2 & 0 & 5\end{array}$

$\begin{array}{llll}1 & 8 & 0 & 51\end{array}$

$\begin{array}{llll}0 & 1 & 0 & 3\end{array}$
Upper Miocene-Continued

Santa Margarita Formation-Continued

Upper phosphatic mudstone member-Continued Unit No. Thickness

96. Siltstone, siliceous; contains diatoms

Ft $\quad$ In $\quad M \quad C m$

95. Siltstone, bentonitic, and bentonite

94. Siltstone, siliceous

93. Siltstone, bentonitic

92. Siltstone, siliceous, slightly bentonitic

91. Bentonite

90. Siltstone, siliceous; contains foraminiferal molds

$\begin{array}{llll}0 & 8 & 0 & 20\end{array}$

$\begin{array}{llll}0 & 3 & 0 & 8\end{array}$

11033

$\begin{array}{llll}0 & .6 & 0 & 1.5\end{array}$

$0,7 \quad 0 \quad 18$

trace

$\begin{array}{llll}1 & 1 & 0 & 33\end{array}$

89. Siltstone and bentonitic siltstone; some phosphatic pellets

88. Sandstone, very fine grained, and siltstone; indurated; about 15 percent phosphatic pellets. Megafossils at base; sharp base. Correlation unit P2. Sample P2-294 from unit

87. Siltstone, bentonitic

$\begin{array}{llll}0 & 4 & 0 & 10\end{array}$

86. Siltstone, siliceous, moderately phosphatic; indurated; $1 \mathrm{ft}$ ( 30 $\mathrm{cm})$ above base is 10 -inch (25$\mathrm{cm}$ ) bed of sandy siltstone with 10 percent phosphatic pellets. Correlation unit S1 near middle

85. Bentonite and bentonitic siltstone

84. Siltstone, sandy, and very fine grained silty sandstone; indurated; about 1 percent phosphatic pellets

$\begin{array}{llll}2 & 2 & 0 & 66\end{array}$

$\begin{array}{llll}2 & 2 & 0 & 66\end{array}$

$\begin{array}{llll}4 & 10 & 1 & 47\end{array}$

$\begin{array}{llll}0 & 4 & 0 & 10\end{array}$ iltstone, bentonitic to siliceous, possibly calcareous; weakly indurated; concretionary zone at top as much as 5 in. $(13 \mathrm{~cm})$ thick, with porous, pale-orange concretions as much as $5 \mathrm{ft}$ $(1.52 \mathrm{~m})$ long; contains abundant foraminiferal molds. Thin bentonite beds at base and 3.6 $\mathrm{ft}(1.10 \mathrm{~m})$ above
82. Siltstone, very sandy, pale-greenish-gray; moderately indurated; about 1 percent phosphatic pellets, mostly coarse grained, brown to pinkish

81. Siltstone, pale-olive-gray; weakly indurated; brown in lower part. Rare phosphatic pellets; abundant fish scales

80. Wackestone, sandy, slightly phosphatic, framework supported. Grains, subangular to subrounded, well-sorted, long axes subparallel; commonly incipiently calcitized. Framework, 32 percent quartz, 14 percent feldspar, 6 percent phosphatic; matrix 2 percent clay minerals, 42 percent carbonate minerals, and 4 percent iron oxide, accessory minerals, 1 percent, include hematite and zircon. 
Upper Miocene-Continued

Santa Margarita Formation-Continued

Upper phosphatic mudstone member-Continued Unit No.

Phosphatic framework, 17 percent pellets with noncentered inclusions, and 17 percent pellets with centered inclusions of quartz, feldspar, hematite, and diatom fragments, 50 percent structureless pellets, and 16 percent fossil fragments. Pellets, regular to slightly irregular spheroids, range from $0.09 \mathrm{~mm}$ to $0.55 \mathrm{~mm}$ in diameter, average diameter 0.18 $\mathrm{mm}$; almost all boundaries sharp, rarely fuzzy; rarely rimmed with hematite or calcite; protruding grains very rare. Graded bedding; some coarse sand in lower part of unit. Upper $10 \mathrm{in} .(25 \mathrm{~cm})$ of unit weakly indurated; rest of unit moderately indurated, semifriable. Contains shell and fish bone fragments less than 1 $\mathrm{mm}$ long, some partially replaced by phosphate. Clam molds very abundant in lower part. Base, very irregular, with sand-filled burrows as much as 3 in. $(8 \mathrm{~cm})$ deep and 2 in. (5 $\mathrm{cm}$ ) in diameter. Sample F1208-31 from lower third of unit

79. Wackestone, silty, moderately phosphatic; very thinly laminated. Grains, subangular to subrounded, well-sorted.

Framework, 18 percent quartz, 10 percent feldspar, 10 percent phosphate; matrix, 20 percent clay minerals and 39 percent dolomite; accessory minerals, 2 percent, include glauconite, chlorite, hematite, magnetite, and muscovite. Phosphatic framework, 38 percent pellets with noncentered inclusions and 30 percent pellets with centered inclusions of quartz, feldspar, zircon, chlorite, and diatom fragments, 20 percent structureless pellets, 5 percent fish bones, 5 percent shell fragments, and 2 percent incipient pellets. Pellets, regular to slightly irregular spheroids, approximately $0.15 \mathrm{~mm}$ in diameter; boundaries very fuzzy, rims commonly ironenriched; nucleus commonly replaced by secondary calcite and rarely replaced by hematite. Shell fragments as much as $\mathbf{2} \mathrm{mm}$ long; shell
Upper Miocene-Continued

Santa Margarita Formation-Continued

Upper phosphatic mudstone member-Continued Unit No.

fragments and apatite veinlets oriented parallel to laminae. Sample F1208-30 from unit

78. Mudstone, moderately phosphatic, silty, sandy; siliceous matrix with hematite veinlets and iron-oxide stain. Grains, very fine, subangular to subrounded, poorly sorted, randomly oriented; commonly incipiently calcitized and feldspar commonly altered to sericite; rare floating grains as large as coarse size. Framework, 18 percent quartz, 12 percent feldspar, and 17 percent phosphate; matrix, 47 percent clay minerals and 4 percent iron oxide; accessory minerals 1 percent, include glauconite, chlorite, hematite, magnetite, zircon, and biotite. Phosphatic framework, 35 percent pellets with noncentered inclusions and 24 percent pellets with centered inclusions of quartz, feldspar, diatom fragments, very rare fish bones, zircon, hematite, and chert, 39 percent structureless pellets, and 2 percent fish-bone and shell fragments. Pellets, regular to slightly irregular spheroids; range from $0.08 \mathrm{~mm}$ and 0.55 $\mathrm{mm}$ in diameter; average diameter $0.20 \mathrm{~mm}$; boundaries sharp to fuzzy; rims commonly siliceous and rarely hematitic; protruding and intruding grains rare; nuklei rarely incipiently calcitized; hematite staining common. Sandy in lower part; lower $1 \mathrm{ft}(30 \mathrm{~cm})$ is very fine grained silty sandstone; indurated; few clam casts. Faint, irregular small-scale laminations and possible crossbedding; may be broken by burrows; poorly exposed at base. Sample F1208-32 from unit

77. Siltstone, mostly very siliceous, some slightly siliceous. Weathered surface looks very thin bedded. About 3 percent phosphatic pellets locally. Fish scales abundant

76. Sandstone, silty, and siltstone slightly sandy. Lower part, light-brown and fine-grained sandstone, upper part, pinkish and very fine grained siltstone. Sandstone grades up to silt- 
Upper Miocene-Continued

Santa Margarita Formation-Continued

Upper phosphatic mudstone member-Continued Unit No.

stone. Phosphatic pellets about

15 percent. Lower part contains megafossil casts and appears burrowed. Base very irregular

75. Siltstone, olive-gray

74. Dolomite, pale-red. Discontinuous lens. 30 percent insoluble residue

73. Siltstone, mostly siliceous, lightgray. Breaks into sharp, small, angular fragments. Microfossil impressions, small, abundant; some with weathered white material. Basal 4 in. $(10 \mathrm{~cm})$, sandy siltstone, weakly indurated. Correlation unit S2

72. Siltstone, sandy, siliceous, slightly phosphatic, moderately indurated. Quartz, coarsegrained, rare. Foraminiferal(?) impressions locally abundant

71. Sandstone, very fine grained, silty, siliceous, indurated. Contains some quartz, coarsegrained. Contains about 15 percent phosphatic pellets, lightbrown, locally concentrated into lenses

70. Bentonite and bentonitic siltstone. Phosphatic pellets, white, finegrained, 30 percent

69. Siltstone and sandy siltstone, siliceous, upper part indurated. Phosphatic pellets, very fine to fine-grained, about 25-30 percent in unit; in upper third of unit, pellets brown and pitted, in rest of unit, pellets white to light-gray

68. Bentonite and bentonitic siltstone. Upper half, phosphatic pellets, white, very fine grained, 10 percent; lower half, phosphatic pellets, light-brown to gray, fine-grained, 25 percent. Pellets concentrated locally in lenses

67. Siltstone, bentonitic. Phosphatic pellets 15 percent

66. Sandstone, calcareous, pale-red. Phosphatic pellets, light to dark, fine-grained, 25 percent Many calcite veins cut unit

65. Siltstone, bentonitic, light-brown Phosphatic pellets, finegrained, 15 percent

64. Siltstone, siliceous; phosphatic pellets, about 15 percent, microfossils in cores of many pellets. Upper part, pale-red to gray, very fine to fine-grained; basal 4 inches $(10 \mathrm{~cm})$, lightbrown, coarse-grained
Upper Miocene-Continued

Santa Margarita Formation-Continued

Upper phosphatic mudstone member-Continued Unir No.

63. Phosphorite, dark-brown, sandy, siliceous matrix, grain supported. Upper 4 inches $(10 \mathrm{~cm})$ of unit, 45 percent phosphatic pellets, medium-grained, darkbrown, some gray; remainder of unit, 70 percent pellets, medium-grained, dark-brown. Sand grains, subangular to subrounded, medium-grained, medium-sorted, randomly oriented; rarely incipiently calcitized. Framework, 31 percent quartz, 18 percent feldspar, and 7 percent phosphatic; matrix, 27 percent clay minerals, 1 percent micrite, 1 percent apatite, and 3 percent iron oxide; accessory minerals, 1 percent, include muscovite, chlorite, magnetite, hematite, and zircon. Small patches of apatite and micrite in matrix. $\mathrm{X}$-ray diffraction analysis indicates matrix composed of opalCT and apatite. Phosphatic framework, 40 percent pellets with noncentered inclusions of quartz, feldspar, and diatom fragments, 50 percent structureless pellets, 5 percent nodule fragments, and 5 percent shell fragments. Pellets, spheroids, regular to slightly irregular; range from $0.08 \mathrm{~mm}$ to $0.45 \mathrm{~mm}$ in diameter; average diameter $0.20 \mathrm{~mm}$; rims, sharp to very sharp; protruding grains rare; faint grain imprints from compaction rare; nuclei rarely incipiently calcitized. Few nodules, rounded; range from $0.3 \mathrm{~mm}$ to $1.6 \mathrm{~mm}$, with and without inclusions. A few siltstone clasts as long as 1.5 in. $(3.8 \mathrm{~cm})$ in base. Base, very irregular, burrowed. Burrows, cross section oval-shaped, as much as 2 in. $(5 \mathrm{~cm})$ in diameter; mostly parallel to base. Lens, 4 in. $(10 \mathrm{~cm})$ deep, cuts into underlying unit, probably channel scour. Correlation unit P3. Samples F1208-33 and P3-294 from unit

62. Claystone, slightly phosphatic, slightly silty, faintly laminated; hematitic patches and partings. Grains, subangular to subrounded, poorly sorted; floating grains, medium-size, rare; grains very rarely incipiently calcitized. Framework, 8 per-

$$
\text { Ft In } M \quad C m
$$


Upper Miocene-Continued

Santa Margarita Formation-Continued

Upper phosphatic mudstone member-Continued Unit No.

cent quartz, 3 percent feldspar, 2 percent structureless phosphatic pellets; matrix, 84 percent siliceous clay minerals, 3 percent iron oxide, and very rare chlorite. Pellets, spheroids, regular to irregular; range from $0.05 \mathrm{~mm}$ to $0.25 \mathrm{~mm}$ in diameter; boundaries, fuzzy to very fuzzy; very many stained with hematite. Sample F1208-34 from unit

61. Siltstone, siliceous; indurated. Phosphatic pellets, gray, finegrained, about $15-20$ percent; some are pitted

60. Sandstone, very fine grained silty, siliceous. Phosphatic pellets, gray to light-grayishbrown, fine-grained, about 10 percent

59. Siltstone, siliceous; some phosphatic pellets

58. Siltstone, highly sheared

57. Mudstone and siltstone, siliceous Phosphatic pellets, 5-10 percent in upper half and about 15 percent in lower half. Quartz, very coarse grained, rare. Some microfossil molds

56. Siltstone and sandstone; sand, very fine grained, siliceous. Phosphatic pellets, as much as 30 percent. Sheared zone. Thickness approximate

55. Claystone, siliceous; laminae, wavy; a few silty partings with grains, subangular to rounded, poorly sorted, preferentially oriented subparallel to laminae. Framework, 3 percent quartz and 2 percent feldspar; matrix, 90 percent clay minerals and 5 percent iron oxide. Phosphatic pellets, spheroidal, approximately $0.30 \mathrm{~mm}$ in diameter boundaries of varying sharpness; rare. Much hematite staining. Sample F1208-44 from unit

54. Claystone, slightly phosphatic, poorly sorted, subangular to round, randomly oriented coarse silt-size grains; faintly laminated siliceous clays with disseminated chlorite and hematite. Contains 7 percent quartz, 3 percent feldspar, 4 percent phosphatic framework, 84 percent clay minerals (matrix), and 2 percent iron oxides (matrix and staining); accessory minerals include
Upper Miocene-Continued

Santa Margarita Formation-Continued

Upper phosphatic mudstone member-Continued Unit No.

Thickness

Ft In $\mathrm{M} \quad \mathrm{Cm}$

chlorite, magnetite, zircon, and muscovite. Phosphatic framework consists of 24 percent pellets with noncentered inclusions and 25 percent pellets with centered inclusions of quartz and diatom fragments (rare), 45 percent structureless pellets, 4 percent compound pellets, and 2 percent shell fragments (less than $1 \mathrm{~mm}$ ). Pellets are regular to slightly irregular spheroids between $0.08 \mathrm{~mm}$ and $0.35 \mathrm{~mm}$ in diameter, (average $0.15 \mathrm{~mm}$ ) with fuzzy boundaries, protruding grains (rare), and hematite replacement (common). Sample F1208-43 from unit

53. Mudstone, sandy, siliceous, moderately phosphatic. Sand grains, subangular to subrounded, fine, poorly sorted, randomly oriented; floating grains, as large as coarse-size very rare; framework grains commonly altered to sericite and rarely to calcite. Framework, 19 percent quartz, 6 percent feldspar, 1 percent chalcedony, 10 percent phosphate; matrix, 61 percent clay minerals, and 3 percent iron oxide. Phosphatic framework, 50 percent pellets with noncentered inclusions and 30 percent pellets with centered inclusions of quartz, feldspar, and very rare chalcedony and diatom fragments, 18 percent structureless pellets, and 2 percent shell and diatom fragments. Pellets, spheroids, regular to slightly irregular; range from $0.07 \mathrm{~mm}$ to $0.30 \mathrm{~mm}$ in diameter; average diameter 0.13 $\mathrm{mm}$; boundaries, fuzzy to very fuzzy; rims rarely of hematite; nuclei commonly incipiently calcitized, protruding grains rare. Correlation unit S3. Sample F1208-42 from unit

52. Mudstone, sandy, slightly phosphatic; faintly laminated grainrich and mud-pellet-rich zones; locally grain supported. Grains, subangular to subrounded, very fine, poorly sorted. Framework, 3I percent quartz, 2 percent feldspar, 5 percent phosphate; matrix, 35 percent clay minerals, 2 per- 
Upper Miocene-Continued

Santa Margarita Formation-Continued

Upper phosphatic mudstone member-Continued Unit No.

$$
\text { FI In } M \quad C m
$$

cent carbonate replacement minerals, 7 percent iron oxide; accessory minerals include chlorite, magnetite, zircon, and muscovite. Many banded concentrations of iron oxides separate mud-pellet zones from grain zones. Phosphatic framework, 75 percent pellets with noncentered inclusions of quartz, feldspar, and very rare diatom fragments, 20 percent structureless pellets, and 5 percent shell fragments. Pellets, spheroids, regular to slightly irregular; range from $0.08 \mathrm{~mm}$ to $0.60 \mathrm{~mm}$ in diameter; average diameter $0.20 \mathrm{~mm}$; boundaries, predominantly sharp; commonly slightly deformed peripherally; rims rarely siliceous. Nuclei, commonly ringed with hematite stain; rarely incipiently calcitized. Sample F1208-41 from unit

51. Siltstone, siliceous. Upper half, moderately phosphatic

50. Siltstone, siliceous; fractured; 5 percent phosphatic pellets

49. Mudstone, sandy, siliceous, slightly phosphatic; faintly laminated. Grains, angular to subangular, poorly sorted. Framwork, 35 percent quartz, 7 percent feldspar, and 9 percent phosphate; matrix, 34 percent clay minerals, 10 percent carbonate minerals, and 3 percent iron oxide; accessory minerals, 2 percent, include glauconite, chlorite, magnetite, zircon, and hematite. Phosphatic framework, 44 percent structureless pellets, 32 percent pellets with noncentered inclusions and 10 percent pellets with centered inclusions of quartz and feldspar, 10 percent nodule fragments with grain inclusions and 3 percent shell fragments less than $1 \mathrm{~mm}$. Pellets, spheroidal, range from $0.10 \mathrm{~mm}$ to $0.30 \mathrm{~mm}$ in diameter; boundaries fuzzy; rims rarely calcareous; many rims of secondary phosphate; nuclei rarely incipiently calcitized. Sample F1210-4 from unit

48. Siltstone, siliceous

47. Bentonite

46. Siltstone, sandy, siliceous; some coarse-grained quartz; most

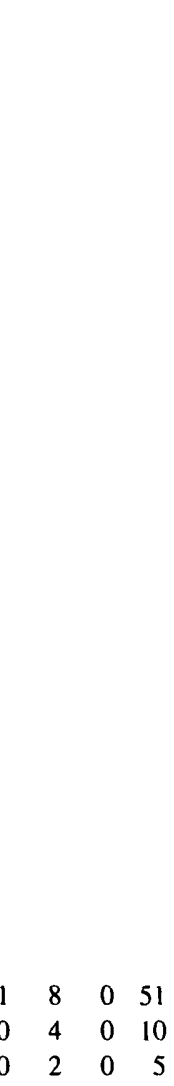

Upper Miocene-Continued

Santa Margarita Formation-Continued

Upper phosphatic mudstone member-Continued Unit No.

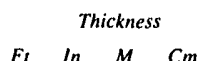

massive, indurated. Sheared. Appears similar to stratigraphic units 44 and 43

45. Siltstone and sandstone, siliceous; fractured

$\begin{array}{llll}1 & 8 & 0 & 51\end{array}$

44. Sandstone, silty, siliceous; lightgray; massive; sand, very fine grained. Contains about 5 percent phosphatic pellets. Similar in appearance and outcrop pattern to underlying unit

$\begin{array}{llll}4 & 8 & 1 & 42\end{array}$

43. Siltstone, sandy, siliceous, and porcelanite; massive

42. Bentonite and bentonitic siltstone Lower half mostly siliceous siltstone. Fractured

$\begin{array}{llll}4 & 8 & 1 & 42\end{array}$

$\begin{array}{llll}0 & 8 & 0 & 20\end{array}$

41. Siltstone, siliceous. Phosphatic pellets, light-gray, 15 percent. Lower third of unit sandy with 30 percent pellets

40. Siltstone, siliceous; may include bentonite; fractured. Phosphatic pellets, 15 percent

39. Siltstone, siliceous. May contain bentonite. Fractured

38. Sandstone, moderately phosphatic, muddy, light-brown; grain-supported. Grains, fine, subangular to subrounded, well-sorted, randomly oriented. Framework, 36 percent quartz, 19 percent feldspar, 2 percent lithic fragments, and 11 percent phosphate; matrix, 28 percent clay minerals, 4 percent iron oxide disseminated throughout matrix; accessory minerals include chlorite, hematite, muscovite, magnetite, and zircon. Phosphatic framework, 39 percent pellets with noncentered inclusions and 10 percent pellets with centered inclusions of quartz, diatom fragments, feldspar, and hematite, 43 percent structureless pellets, 5 percent nodule and shell fragments, and 3 percent compound pellets. Pellets, spheroids, regular to slightly irregular; range from $0.12 \mathrm{~mm}$ to $0.45 \mathrm{~mm}$ in diameter, average diameter $0.22 \mathrm{~mm}$; boundaries, sharp; protruding grains rare; commonly slightly deformed peripherally at contacts with other pellets or grains; nuclei rarely incipiently calcitized. Unit looks very burrowed. Clam molds very abundant at base. Base very irregular. Sample F1208-40 from unit 
Upper Miocene-Continued

Santa Margarita Formation-Continued

Upper phosphatic mudstone member-Continued

Unit No.

\begin{tabular}{lllll}
\multicolumn{5}{c}{ Thickness } \\
Ft & In & $M$ & $C m$ \\
& & & \\
& & & \\
& & & \\
3 & 6 & 1 & 7 \\
trace & & \\
0 & 10 & 0 & 25 \\
trace & & \\
0 & 10 & 0 & 25
\end{tabular}

37. Siltstone, somewhat bentonitic(?) olive-gray. Phosphatic pellets light-gray, very fine grained, about 5 to 10 percent. Correlation unit S4

36. Bentonite(?)

35. Siltstone, siliceous, olive-gray

34. Bentonite(?)

33. Siltstone, siliceous; phosphatic pellets, brown, rare

32. Sandstone, feldspathic, very fine grained. Gradationally coarsens to base of fine-grained sandstone. Phosphatic pellets, brown, fine- to mediumgrained, about 5 percent; basal 2 in. $(5 \mathrm{~cm})$ contains 25 percent pellets. Basal, I ft ( 30 $\mathrm{cm}$ ), tan; contains many internal molds of clams; very irregular base, sand-filled burrows penetrate underlying unit

31. Siltstone, olive-gray

30. Siltstone, olive-gray; contains about 20 percent phosphatic pellets. Upper 2 in. $(5 \mathrm{~cm})$ of unit, brownish-gray; contains phosphatic pellets, brown, fineto medium-grained, about 50 percent; grades upward into overlying unit. Correlation unit P4

29. Sandstone, calcareous, very light gray; indurated. Fossils, very abundant

28. Bentonite(?)

27. Sandstone, very fine grained, olive brown; phosphatic pellets, dark-brown, few. Fossils at base

26. Sandstone, gray, very abundant fossils

$\begin{array}{llll}2 & 10 & 0 & 86\end{array}$

$\begin{array}{llll}1 & 10 & 0 & 56\end{array}$

$\begin{array}{lll}8 & 0 & 20\end{array}$

$\begin{array}{llll}2 & 4 & 0 & 71\end{array}$

$\begin{array}{llll}0 & 2 & 0 & 5\end{array}$

$\begin{array}{llll}1 & 0 & 0 & 30\end{array}$

$\begin{array}{llll}0 & 11 & 0 & 28\end{array}$

25. Sandstone, fine-grained, brown; phosphatic pellets, about 3 percent. Fossils abundant

24. Sandstone, very fine to finegrained, brown. Fossils abundant

23. Siltstone, siliceous. Fossils locally abundant. Sandstone, very fine grained, 6 in. $(15 \mathrm{~cm})$ zone 10 $\mathrm{ft}(3.05 \mathrm{~m})$ above base; contains megafossils

$\begin{array}{llll}16 & 6 & 5 & 3\end{array}$

22. Sandstone, fine-grained. Phosphatic pellets, dark-brown, 10 percent. Megafossils common

21. Sandstone, fine-grained, brown; locally very well sorted. Phosphatic pellets, 5 percent. Fossils very abundant

\section{Upper Miocene-Continued}

Santa Margarita Formation-Continued

Upper phosphatic mudstone member-Continued Unit No.

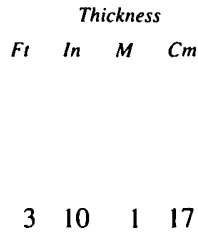

$\begin{array}{llll}3 & 10 & 1 & 17\end{array}$ Ft In $M \quad C m$

20. Sandstone, very fine grained, light-grayish-brown to paleorangish-gray. Irregular zone, highly fossiliferous, about $2 \mathrm{ft}$ $(51 \mathrm{~cm})$ above base

19. Siltstone, siliceous; weathers platy. Phosphatic pellets, lightgray to pinkish-gray, about 5 percent. Local calcareous concretions as large as $1.4 \mathrm{ft}$ by 3 $\mathrm{ft}(43 \mathrm{~cm}$ by $91 \mathrm{~cm})$ at base

18. Siltstone, siliceous

$\begin{array}{llll}4 & 11 & 1 & 50\end{array}$

17. Siltstone, siliceous; 15 percent phosphatic pellets

16. Siltstone siliceous; 5 percent phosphatic pellets

15. Sandstone, silty; sandy siltstone at top

14. Bentonite; sheared

13. Siltstone, siliceous, indurated in upper $1.6 \mathrm{ft}(49 \mathrm{~cm})$

12. Sandstone, very fine grained; 5 percent phosphatic pellets. Upper part, light-gray, very fine grained; lower part, dark-brown

$\begin{array}{llll}2 & 11 & 0 & 89\end{array}$

11. Sandstone, orange-stained, 5 percent phosphatic pellets. Fossils very abundant

$\begin{array}{llll}0 & 10 & 0 & 25\end{array}$

10. Sandstone, very fine grained, light-tan; phosphatic pellets, dark-brown, 5 percent. Fossils abundant at base

$\begin{array}{llll}4 & 6 & 1 & 37\end{array}$

9. Siltstone, siliceous; some phosphatic pellets

$\begin{array}{llll}6 & 7 & 2 & 1\end{array}$

8. Sandstone, calcareous. Unit thickness, variable; thins in places to 1 in. $(3 \mathrm{~cm})$. Fossils common

7. Siltstone, bentonitic, olive-gray

6. Siltstone, siliceous, dark-gray; indurated. About 15 percent phosphatic pellets

$\begin{array}{llll}0 & 7 & 0 & 18\end{array}$

$\begin{array}{llll}2 & 0 & 0 & 61\end{array}$

$\begin{array}{llll}1 & 4 & 0 & 41\end{array}$

5. Sandstone, somewhat calcareous; indurated. Phosphatic pellets, dark-brown, about 10 percent. Fossiliferous

$\begin{array}{llll}1 & 1 & 0 & 33\end{array}$

4. Siltstone; light-gray; appears slightly diatomaceous

$\begin{array}{llll}2 & 5 & 0 & 74\end{array}$

3. Shale, olive-gray. Thickness estimated for this unit and two underlying units

Total thickness of the upper phosphatic mudstone member

$\overline{302} \overline{1} \overline{92} \overline{0}$

Upper Miocene:

Santa Margarita Formation:

Lower sandstone member:

1. Siltstone, light-gray, indurated

$\begin{array}{llll}11 & 0 & 3 & 35\end{array}$

Total measured thickness of the lower sandstone member
12036

$\frac{-}{12} \overline{2} \frac{}{71}$ 


\section{Trench 295}

(Measured by H. D. Gower, 1964)

LOCATION: SW1/4NW1/4 sec. 8, T. 9 N., R. 26 W. (S.B.B. \& M.) in the New Cuyama, California quadrangle

ATTITUDE OF BEDDING: Approximately N. $50^{\circ} \mathrm{W} .66^{\circ} \mathrm{NE}$.

TREND OF TRENCH: Approximately N. $45^{\circ} \mathrm{E}$.

\section{Upper Miocene:}

Santa Margarita Formation:

Upper phosphatic mudstone member: Unit No.

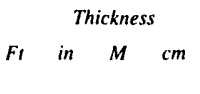

88. Siltstone and claystone, siliceous, light-gray to medium-gray, greenish stains, locally, moderately indurated; breaks into irregular 2 to 4 in. (5 to $10 \mathrm{~cm}$ ) fragments. Phosphatic pellets, rare, very small, white to tan. Small fish bones and scales locally abundant

87. Siltstone and claystone, siliceous, moderately indurated but less so than overlying unit, breaks into irregular $1 / 4$ to 1 inch $(0.6$ to $2.5 \mathrm{~cm}$ ) fragments. Phosphatic pellets, locally concentrated, make up less than 1 percent of unit. Fish scales, scattered

86. Claystone and siltstone, bentonitic; weakly indurated

85. Siltstone, somewhat siliceous, moderately indurated. Phosphatic pellets, brown, about 1 percent. Unit, not completely exposed, fractured; friable silt may be recent filling of cracks

84. Sandstone, very fine grained, or siltstone, light-yellowishbrown; friable. Phosphatic pellets, dark-brown, about 3-5 percent; most abundant at top of unit

83. Sandstone, very fine grained, or siltstone. Upper third of unit, moderately indurated. Phosphatic pellets, brown to tan, surfaces look waxy; content ranges from 3-80 percent; averages 15 percent; most abundant in lower third of unit

(n)

$\begin{array}{llll}1 & 7 & 0 & 48\end{array}$

$\begin{array}{llll}0 & 5 & 0 & 13\end{array}$

$1 \quad 1 \quad 0 \quad 33$

$\begin{array}{llll}0 & 11 & 0 & 28\end{array}$

$\begin{array}{llll}1 & 18 & 0 & 51\end{array}$

82. Siltstone, somewhat siliceous, light-gray except for upper 7 in. $(18 \mathrm{~cm})$ which is mediumgray. Unit fractures into $1 / 4$ to $3 / 4$ in. $(0.6$ to $1.9 \mathrm{~cm})$ fragments. Friable zone of very fine grained sandstone or siltstone, 6 in. $(15 \mathrm{~cm})$, that is 7 in. $(18$ $\mathrm{cm}$ ) below top may not be in place. No pellets; some fish scales

81. Sandstone, very fine grained, or siltstone; moderately indurated. Phosphatic pellets, brown, very

Upper Miocene-Continued

Santa Margarita Formation-Continued

Upper phosphatic mudstone member-Continued Unit No.

Thickness

small to very large; white, very small in upper 4 in. $(10 \mathrm{~cm})$; about 15 to 25 percent. Small fish-bone fragments abundant

80. Siltstone, and sandstone, very fine grained. Phosphatic pellets about 5 percent. Contains fish fragments

$\begin{array}{llll}0 & 10 & 0 & 25\end{array}$

79. Sandstone, very fine grained, and siltstone, bentonitic; highly sheared. About 2 percent phosphatic pellets

$\begin{array}{llll}0 & 7 & 0 & 18\end{array}$

78. Sandstone, very fine grained; moderately indurated. Phosphatic pellets, about 35 percent. Quartz, coarsegrained, rare

$\begin{array}{llll}1 & 2 & 0 & 36\end{array}$ iltstone, siliceous. About 2 percent phosphatic pellets. Fish scales rare

$\begin{array}{llll}0 & 6 & 0 & 15\end{array}$

$\begin{array}{llll}1 & 0 & 0 & 30\end{array}$

76. Siltstone, siliceous. Phosphatic pellets rare except in lower 2 in. $(5 \mathrm{~cm})$ of light-gray siliceous shale which contains about 15 percent

75. Siltstone, probably bentonitic, medium-gray; sheared

$\begin{array}{llll}1 & 7 & 0 & 48\end{array}$

$\begin{array}{llll}0 & 7 & 0 & 18\end{array}$

74. Siltstone, siliceous; moderately indurated. Phosphatic pellets, rare

$\begin{array}{llll}0 & 6 & 0 & 15\end{array}$

73. Siltstone, possibly bentonitic; medium-gray; weakly indurated. Phosphatic pellets, about 3 percent

$\begin{array}{llll}0 & 5 & 0 & 13\end{array}$

72. Sandstone, very fine grained, or siltstone; moderately indurated. Phosphatic pellets, range from 5 to 60 percent; average 25 percent. Basal 6 in. $(15 \mathrm{~cm})$ of unit is phosphatic siliceous mudstone, which was not sampled. Very irregular contact between sandstone and mudstone. Correlation unit PI is upper $1 \mathrm{ft}(30 \mathrm{~cm})$. Sample Pl-295 from upper $1 \mathrm{ft}$

71. Siltstone, bentonitic; weakly indurated

70. Siltstone, siliceous. Phosphatic pellets less than 1 percent. Upper 1 in. $(3 \mathrm{~cm})$ of unit locally contains abundant pellets

69. Siltstone, tuffaceous, weakly indurated. Poorly exposed

68. Siltstone, siliceous; about 5 percent phosphatic pellets

$\begin{array}{llll}0 & 6 & 0 & 15\end{array}$

$\begin{array}{llll}1 & 2 & 0 & 36\end{array}$

67. Siltstone, bentonitic, and bentonite; highly sheared. Slightly phosphatic

$\begin{array}{llll}1 & 5 & 0 & 43\end{array}$

66. Siltstone, or sandstone, very fine grained, calcareous; indurated; 
Upper Miocene-Continued

Santa Margarita Formation-Continued

Upper phosphatic mudstone member-Continued

Unit No.

\begin{tabular}{|c|c|c|c|}
\hline \multicolumn{4}{|c|}{ Thickness } \\
\hline$F t$ & In & $M$ & $\mathrm{Cm}$ \\
\hline 0 & 5 & 0 & 13 \\
\hline 2 & 5 & 0 & 74 \\
\hline 1 & 7 & 0 & 48 \\
\hline 1 & 11 & 0 & 58 \\
\hline 0 & 7 & 0 & \\
\hline
\end{tabular}

broken. Phosphatic pellets rare Megafossils common

65. Siltstone, bentonitic, and bentonite; slightly sheared

64. Sandstone, very fine grained, or siltstone, siliceous; indurated. Phosphatic pellets, about 1 percent. Megafossil fragments abundant

63. Bentonite and bentonitic siltstone; weakly indurated

62. Siltstone, porcelaneous, to silty bentonite. Slightly phosphatic. One megafossil fragment

$\begin{array}{llll}0 & 7 & 0 & 18\end{array}$

61. Siltstone, siliceous, diatomaceous, slightly phosphatic. Upper 8 in. $(20 \mathrm{~cm})$ weakly indurated and probably bentonitic

$\begin{array}{llll}3 & 5 & 1 & 4\end{array}$

60. Sandstone, very fine grained, or siltstone, may be tuffaceous; upper half, light-greenish-gray; lower half, weathered orange; moderately indurated. Phosphatic pellets, average about 30 percent. Correlation unit P2. Sample' P2-295 from unit

59. Siltstone, siliceous, very pale olive gray. Phosphatic pellets less than 1 percent. Some phosphatic fish scales. Correlation unit $\mathrm{Sl}$

58. Sandstone, very fine grained; friable at top. Middle third of unit contains megafossils and about 20 percent phosphate pellets; other two-thirds about 5 percent

57. Porcellanite, indurated

56. Siltstone, calcareous; weakly indurated

55. Siltstone, calcareous; moderately indurated, but weakly indurated in upper 2 in. $(5 \mathrm{~cm})$

54. Porcellanite, silty and calcareous in places; indurated

$\begin{array}{llll}0 & 10 & 0 & 25\end{array}$

$\begin{array}{llll}3 & 8 & 1 & 12\end{array}$

$\begin{array}{llll}1 & 1 & 0 & 33\end{array}$

$\begin{array}{llll}0 & 5 & 0 & 13\end{array}$

$\begin{array}{llll}0 & 1 & 0 & 3\end{array}$

$\begin{array}{llll}0 & 8 & 0 & 20\end{array}$

53. Siltstone; slightly phosphatic; appears tuffaceous; lower 6 in. $(15 \mathrm{~cm})$ moderately indurated, contains a few megafossils

52. Claystone, bentonitic; light-olivegray

51. Siltstone, light-gray; few poorly preserved megafossil casts

50. Siltstone; mostly indurated. Few quartz grains, very coarse. Siliceous(?) microfossils, white, spherical, very abundant, partly leached out. Fish scales plentiful. Thin bentonite bed at top

49. Bentonite

48. Sandstone, very fine grained, or siltstone; indurated. About 20 $\begin{array}{llll}0 & 4 & 0 & 10\end{array}$

Upper Miocene-Continued

Santa Margarita Formation-Continued

Upper phosphatic mudstone member-Continued Unit No.

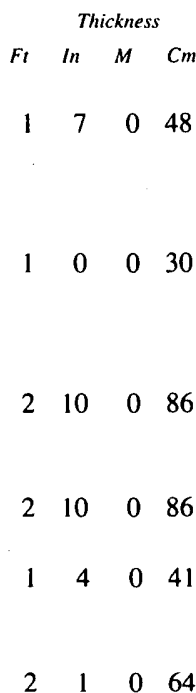

$170 \quad 48$

$\begin{array}{llll}2 & 10 & 0 & 86\end{array}$

$140 \quad 4$

21064

percent phosphatic pellets. Irregular base

47. Siltstone, light-olive, upper part bentonitic. Bentonite, top 3 in. $(8 \mathrm{~cm})$. Microfossils, spherical, abundant

46. Siltstone, indurated. Phosphatic pellets, about 10 percent. Microfossils, spherical, abundant

45. Siltstone; locally indurated. Abundant spherical microfossils; rare fish scales

44. Bentonite; some bentonitic siltstone at base

43. Siltstone, locally bentonitic. Microfossils, spherical, abundant

42. Siltstone, locally bentonitic. Phosphatic pellets, rare, local, especially in upper 1 in. (3 $\mathrm{cm}$ ). Microfossils, spherical, abundant; fish scales, common

41. Sandstone, very fine grained, yellowish-brown; mostly friable. Phosphatic pellets, about 15 percent in upper $2.3 \mathrm{ft}$ (70 $\mathrm{cm})$; about 5 percent in lower $0.5 \mathrm{ft}(15 \mathrm{~cm})$

$\begin{array}{llll}2 & 10 & 0 & 86\end{array}$

40. Siltstone and porcelanite; slightly phosphatic locally; thinly bedded. Top of unit, calcareous; lower $1 \mathrm{ft}(30 \mathrm{~cm})$, indurated. Correlation unit $\mathrm{S} 2$

39. Siltstone; indurated. About 20 percent phosphatic pellets

38. Siltstone, somewhat porcelaneous

37. Sandstone, very fine grained, yellowish-gray, mostly friable. Phosphatic pellets, very small, about 10 percent

36. Siltstone; indurated locally. Phosphatic pellets, very small,

- about 20 percent. Top of unit, friable and bentonitic; in lower 7 in. $(18 \mathrm{~cm})$, slightly bentonitic

35. Sandstone, very fine grained; friable. Some quartz, coarsegrained. Phosphatic pellets, about 10 percent. Megafossils rare

$\begin{array}{llll}0 & 2 & 0 & 5\end{array}$

34. Siltstone, some bentonite. Phosphatic pellets, irregularly distributed, about 20 percent

33. Siltstone, siliceous. Phosphatic pellets, light-gray, about 20 percent

32. Phosphorite, yellowish-brown; mostly friable to semifriable; pelletal. Phosphatic pellets, averages 80 percent. Upper 2 in. $(5 \mathrm{~cm})$ of unit, indurated 
Upper Miocene-Continued

Santa Margarita Formation-Continued

Upper phosphatic mudstone member-Continued Unit No.

contains about 30 percent phosphatic pellets. Correlation unit P3

31. Sandstone, very fine grained; friable to indurated. Phosphatic pellets, about 20 percent

30. Bentonite

29. Siltstone and some sandstone, very fine grained; indurated. Phosphatic pellets, 30 percent in 7 in. $(18 \mathrm{~cm})$ zone $3 \mathrm{ft}(91$ $\mathrm{cm})$ below top of unit; 15 percent in underlying $2.4 \mathrm{ft}$ ( 73 $\mathrm{cm}$ ), and average of 5 percent in remainder of unit

28. Phosphorite, about 70 percent pelletș; indurated

27. Siltstone, siliceous; indurated. Phosphatic pellets, less than 5 percent average in unit; most abundant in upper 6 in. (15 $\mathrm{cm})$. Contains megafossils and possibly Foraminifera

26. Siltstone, bentonitic(?); moderately indurated

25. Siltstone; siliceous, indurated. Phosphatic pellets, 5 percent. Correlation unit S3

24. Siltstone; indurated. Phosphatic pellets, 15-60 percent, mostly in upper part; unit about 30 percent indurated

23. Siltstone, siliceous; about 5 percent phosphatic pellets

22. Sandstone, very fine grained, yellow; about 30 percent phosphatic pellets

21. Bentonite

20. Porcellanite, sheared

19. Bentonite; porcellanite inclusions; sheared

18. Porcellanite, indurated

17. Siltstone, weakly indurated

16. Siltstone, siliceous. Phosphatic pellets, 5 percent in upper half, about 30 percent in lower half

15. Siltstone or very fine grained sandstone; about 5-10 percent phosphatic pellets

14. Porcellanite, indurated; bentonitic, 1 in. $(2 \mathrm{~cm})$ and $2 \mathrm{ft}$ $(61 \mathrm{~cm})$ above base

13. Siltstone, siliceous; about 5 percent phosphatic pellets

12. Phosphorite, about 50 percent pellets; siliceous; siltstone matrix

$\begin{array}{llll}2 & 1 & 0 & 64\end{array}$

$\begin{array}{llll}0 & 1 & 0 & 3\end{array}$

$\begin{array}{llll}1 & 6 & 0 & 46\end{array}$

$150 \quad 43$

$\begin{array}{llll}3 & 11 & 1 & 19\end{array}$

$\begin{array}{llll}0 & 7 & 0 & 18\end{array}$

$\begin{array}{llll}0 & 2 & 0 & 5\end{array}$

$\begin{array}{llll}0 & 11 & 0 & 28\end{array}$

$\begin{array}{llll}0 & 4 & 0 & 10\end{array}$

$\begin{array}{llll}0 & 10 & 0 & 25\end{array}$

$\begin{array}{llll}0 & 2 & 0 & 5\end{array}$

$\begin{array}{llll}2 & 6 & 0 & 76\end{array}$

$\begin{array}{llll}2 & 7 & 0 & 79\end{array}$

$\begin{array}{lll}10 \quad 0 & 86\end{array}$

$\begin{array}{llll}0 & 7 & 0 & 20\end{array}$

$\begin{array}{llll}0 & 10 & 0 & 25\end{array}$

11. Siltstone, siliceous; about 3 percent phosphatic pellets; bentonite in top 2 in. $(5 \mathrm{~cm})$. Correlation unit $\mathrm{S} 4$.

$\begin{array}{llll}2 & 8 & 0 & 81\end{array}$
Upper Miocene-Continued

Santa Margarita Formation-Continued

Upper phosphatic mudstone member-Continued Unit No.

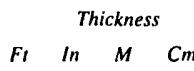

average 30 percent in unit; 10-50 percent in upper 7 in. $(18 \mathrm{~cm})$

9. Siltstone, bentonitic; olive-gray

8. Sandstone, very fine grained, yellow; friable. Phosphatic pellets, about 30 percent.

Burrows, very abundant; fish bones, abundant; small gastropods in base. Top sheared; base sharp; thickness unreliable. Correlation unit P4.

Sample P4-295 from unit

$\begin{array}{llll}1 & 8 & 0 & 51\end{array}$

7. Porcellanite, silty, calcareous. Poorly preserved megafossils, abundant

120036

6. Sandstone, very fine grained, light-brown, friable; probably bentonitic at top. Poorly exposed

$\begin{array}{llll}1 & 7 & 0 & 48\end{array}$

$\begin{array}{llll}3 & 0 & 0 & 91\end{array}$

5. Siltstone, siliceous. Very abundant megafossils

4. Siltstone, siliceous

3. Sandstone, very fine grained; about 15 percent pellets

2. Siltstone, siliceous, slightly phosphatic

$\begin{array}{lll}10 & 0 & 25\end{array}$

$\begin{array}{llll}1 & 8 & 0 & 51\end{array}$

$\begin{array}{llll}11 & 0 & 3 & 35\end{array}$

$\begin{array}{llll}1 & 0 & 0 & 30\end{array}$

$\begin{array}{llll}4 & 5 & 1 & 35\end{array}$

1. Bentonite

$\begin{array}{llll}0 & 11 & 0 & 28\end{array}$

Total measured thickness of upper phosphatic mudstone member: $\quad \begin{array}{lllll}147 & 9 & 45 & 2\end{array}$

Section to south is highly sheared due to proximity to Ozena fault

\section{Trench 296}

(Measured by H. D. Gower, 1964; F and E numbered samples described petrographically by T. L. Vercoutere)

LOCATION: SE $1 / 4$ SW1/4 sec. 8, T. 9 N., R. 26 W. (S.S.B.\&M.) in the

Salisbury Potrero, California quadrangle

ATTITUDE OF BEDDING: N. $38^{\circ}$ W. $36^{\circ} \mathrm{S}$. (good)

TREND OF TRENCH: Approximately N. $80^{\circ} \mathrm{E}$

Upper Miocene:

Santa Margarita Formation:

Upper sandstone member: Unir No.

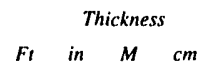

120. Sandstone, white, friable; irregular contact.

Not measured

Upper Miocene:

Santa Margarita Formation:

Upper phosphatic mudstone member:

119. Siltstone, brown- to olive-gray, highly fractured; breaks into small fragments; brown stains on surface

118. Siltstone, brown- to olive-gray; brown stains on surface; breaks into small fragments
$1 \quad 110058$ 
Upper Miocene-Continued

Santa Margarita Formation-Continued

Upper phosphatic mudstone member-Continued

Unit No.

Ft In $\quad M \quad C m$

117. Siltstone, greenish-gray; dark-

bluish-gray stained surfaces; somewhat more massive and breaks into larger pieces than stratigraphic unit 118. Phosphatic pellets, small, brown, about 2 percent; small nodules

$\begin{array}{llll}2 & 8 & 0 & 81\end{array}$

116. Siltstone, light-gray; brown-

stained surfaces; even textured; breaks into small fragments. Upper 10 in. $(25 \mathrm{~cm})$ bentonitic. Unit appears similar to stratigraphic unit 118

115. Siltstone, greenish-gray. Few megafossil casts in lower part. Possible bentonite laminae 11 in. $(28 \mathrm{~cm})$ below top. Basal 5 in. $(13 \mathrm{~cm})$ very fine grained silty sandstone, contains 5 percent pellets. Similar to stratigraphic unit 117 , except only has $1 / 2$ percent phosphatic pellets

$\begin{array}{llll}3 & 0 & 0 & 91\end{array}$

$\begin{array}{llll}2 & 7 & 0 & 79\end{array}$

114. Siltstone, tan to light-gray; massive. Highly fractured with fine gypsum grains on fracture surfaces; some fractures filled with sand, very fine grained. Contains some phosphatic pellets and quartz, coarse-grained. May contain some bentonite

113. Siltstone, greenish-gray; moderate to very calcareous, especially in 5 in. $(15 \mathrm{~cm})$ zone $1 \mathrm{ft}(30$ $\mathrm{cm})$ above base; some sandstone, very fine grained, and siltstone, sandy. Nodules, very abundant. Phosphatic pellets, dark-brown, about 4 percent. Quartz, coarse-grained, about 1 percent. Megafossils common. Similar to stratigraphic unit 117

112. Bentonite

111. Siltstone, partly siliceous, slightly phosphatic; highly fractured. Few small fossils, Yoldia cooperii supramontereyensis Amold and others. Six in. (15 $\mathrm{cm})$ below top 8 in. $(20 \mathrm{~cm})$ indurated zone, light-gray with brown-stained surfaces. Lower $1.1 \mathrm{ft}(33 \mathrm{~cm})$, silty sandstone, fine-grained siliceous with 5 percent phosphatic pellets and nodules

110. Siltstone, siliceous, light-gray brown-stained surfaces, indurated. Few phosphatic pellets. Upper half, small fossils abundant; middle 5 in. $(13 \mathrm{~cm})$ is more shaly than rest of unit;
Upper Miocene-Continued

Santa Margarita Formation-Continued

Upper phosphatic mudstone member-Continued Unit No.

lower half, megafossils, resis$\tan t$

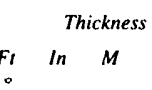

109. Siltstone, some parts look bentonitic, pale-olive-gray; moderately indurated. Fossils rare

$\begin{array}{llll}0 & 2 & 0 & 5\end{array}$

108. Siltstone, slightly calcareous, light-gray; white-stained surface; indurated. Interbedded with siltstone, bentonitic, olive-gray, and bentonite. Lower $2 \mathrm{ft}(51 \mathrm{~cm})$ of unit, brown-stained, highly fractured. Much of unit broken because of swelling of bentonite

107. Siltstone; light-gray; brownstained surfaces. Quartz grains, coarse, abundant locally. Upper siltstone grades down to silty sandstone, very fine grained. Phosphatic pellets, about 6 percent. Fish bones, abundant locally. Base more indurated than rest of unit

106. Siltstone, siliceous, light-gray; massive, indurated. Megafossils and fish scales common. Breaks into large blocks except in upper 8 in. $(20 \mathrm{~cm})$, which is more shaly, light-olive-gray

105. Siltstone, siliceous, light-gray, massive, indurated. Phosphatic pellets, about 1 percent. Mammal bones, fish scales rare

104. Siltstone, partly bentonitic; laminated

103. Siltstone, sandy, light-gray to tan; massive, moderately indurated Phosphatic pellets, about 15 percent, pale-pinkish-gray at top, dark-brown at base. Sandy siltstone grades down to very fine grained sandstone or siltstone at base. Sample CA-1 from this and two underlying units

102. Sandstone, very fine grained; may be slightly bentonitic; very friable. Phosphatic pellets, dark-brown, about 30 percent

101. Sandstone, very fine grained, or siltstone. Phosphatic pellets, light and dark brown, 20 percent. Base, very irregular; large burrows present

100. Siltstone, light-gray, brownstained. Upper part, bentonitic(?), laminated; lower part, massive. Sample CA-2 from unit 
Upper Miocene-Continued

Santa Margarita Formation-Continued

Upper phosphatic mudstone member-Continued Unit No.

percent in 7 in. $(18 \mathrm{~cm})$ zone 4

in. $(10 \mathrm{~cm})$ below top; 45

percent in lower 11 inches $(28$

$\mathrm{cm})$. Sandy siltstone at top.

Sample CA-3 from unit

98. Siltstone, light-gray with brown stains

97. Siltstone, bentonitic

96. Siltstone; about 2 percent phosphatic pellets

95. Siltstone; about 5 percent phosphatic pellets

94. Phosphorite, sandy; about 70 percent phosphatic pellets. Correlation unit PI. Sample CA-5 from unit

$\begin{array}{llll}1 & 10 & 0 & 56\end{array}$

$\begin{array}{llll}1 & 4 & 0 & 41\end{array}$

$\begin{array}{llll}0 & 4 & 0 & 10\end{array}$

$\begin{array}{llll}0 & 11 & 0 & 28\end{array}$

$\begin{array}{llll}0 & 2 & 0 & 5\end{array}$

$\begin{array}{llll}0 & 10 & 0 & 25\end{array}$

93. Siltstone, bentonitic, and bentonite. Sample CA-6 from this and four underlying units

92. Siltștone; weathers brown. Few phosphatic pellets. Bedding attitude: N. $38^{\circ}$ W. $36^{\circ} \mathrm{S}$.

91. Siltstone, olive-gray, bentonitic at top

90. Sandstone, white, very fine grained. Contains black grains, 15 percent, may be phosphatic pellets. Upper half of unit, silty, slightly calcareous, and fossiliferous; lower half, sandstone, orangish-brown, finegrained, friable; contains abundant pebbles as long as $1 / 2$ in. $(1.3 \mathrm{~cm})$. Base very irregular

89. Siltstone, partly bentonitic; weakly indurated. Some phosphatic pellets

$\begin{array}{llll}0 & 6 & 0 & 15\end{array}$

$\begin{array}{llll}0 & 3 & 0 & 8\end{array}$

$\begin{array}{llll}3 & 0 & 0 & 91\end{array}$

$\begin{array}{llll}1 & 8 & 0 & 51\end{array}$

$\begin{array}{llll}1 & 2 & 0 & 36\end{array}$

88. Sandstone, somewhat calcareous; indurated. Phosphatic pellets at top. Small megafossils abundant. Sample CA-7 from unit

87. Siltstone, siliceous; contains phosphatic pellets, white, few. Upper $2 \mathrm{ft}(61 \mathrm{~cm})$ of unit, bentonitic, broken; bentonite bed below it, 2 in. $(5 \mathrm{~cm})$ Sample CA-8 from unit

86. Sandstone, very fine grained. Phosphatic pellets, about 30 percent. Some megafossils, phosphatized. Top, possibly bentonitic; base, irregular, sharp. Correlation unit P2. Sample CA-9 from unit

85. Siltstone, siliceous; bentonitic(?) laminae. Sample CA-10 from this and underlying unit

84. Siltstone, siliceous, slightly bentonitic. Correlation unit SI

83. Sandstone, very calcareous, poorly sorted. Phosphatic pellets, about 35 percent. Small
Upper Miocene-Continued

Santa Margarita Formation-Continued

Upper phosphatic mudstone member-Continued

Unit No.

Thickness

Ft In $M \quad C m$

gastropods abundant in lower part of unit. Sample CA-11 from unit

11033

82. Siltstone, siliceous, somewhat calcareous, white; indurated. Sandy bed, calcareous, 2 in. ( 5 $\mathrm{cm}$ ) thick, weakly indurated, 1 in. $(3 \mathrm{~cm})$ below top. Sample CA-12 from this unit and three underlying units

$\begin{array}{llll}4 & 0 & 1 & 22\end{array}$

81. Siltstone, siliceous, bentonitic; moderately indurated in lower half of unit

80. Bentonite

79. Siltstone, siliceous, light-gray, brown-stained; indurated. Microfossils, white, abundant

78. Sandstone, phosphatic, pelletal, muddy, light-gray. Grains, fine, subangular to subrounded, medium-sorted, randomly oriented; floating grains, medium to coarse, rare. Framework supported. Framework, 33 percent quartz including polycrystalline quartz, rare, 9 percent feldspar, 2 percent lithic fragments, 21 percent phosphatic; matrix, 33 percent clay minerals. Phosphatic framework, 43 percent pellets with noncentered inclusions and 28 percent pellets with centered inclusions of quartz, feldspar, magnetite, zircon, and diatom fragments, 18 percent structureless pellets, 12 percent shell and fish-bone fragments, 6 percent compound pellets, 2 percent intraclasts, granule-size, subrounded. Pellets, spheroids, regular to slightly irregular; range from $0.09 \mathrm{~mm}$ to 0.35 $\mathrm{mm}$ in diameter; average diameter $0.17 \mathrm{~mm}$; boundaries sharp; rims, rarely calcareous or secondary phosphate; few nuclei incipiently calcitized. Some framework silicates incipiently altered to sericite or calcite. Samples CA-13, F1208-19, and E1205-30 from unit

77. Siltstone, slightly bentonitic, moderately indurated. Sample CA-14 from this unit and four underlying units

76. Mudstone, phosphatic, pelletal, silty. Grains, subrounded, poorly sorted; floating grains, medium, rare. Framework, 13 percent quartz, 7 percent feld- 
Upper Miocene-Continued

Santa Margarita Formation-Continued

Upper phosphatic mudstone member-Continued Unit No.

spar, and 28 percent phosphate;

Thickness

matrix, 50 percent clay miner-

als, and 2 percent iron oxide;

primarily montmorillonite and disseminated illite and

hematite; accessory minerals

include zircon, hemátite, mus-

covite, magnetite, and chlorite.

Phosphatic framework, 50 per-

cent pellets with noncentered

inclusions and 7 percent pellets

with centered inclusions of

quartz and lesser amounts of

feldspar, diatom fragments,

magnetite, and rarely mus-

covite, 40 percent structureless

pellets and 3 percent shell frag-

ments. Pellets, spheroids; range

from 0.08 to- $0.40 \mathrm{~mm}$ in

diameter; average diameter

$0.20 \mathrm{~mm}$; boundaries, moder-

ately sharp to fuzzy.

Compound pellets, common,

especially in pellet-supported

areas where they may be

slightly deformed and incased

by secondary phosphate. Ben-

tonitic siltstone, 4 in. $(10 \mathrm{~cm})$

zone, weakly indurated, $1.5 \mathrm{ft}$

$(46 \mathrm{~cm})$ above base. Sample

F1208-18 from unit

75. Bentonite

74. Siltstone and porcelaneous siltstone, some phosphatic pellets; slightly bentonitic at top

73. Siltstone, porcelaneous

72. Phosphorite, 75 percent pellets, sandy, very fine grained; 35 percent pellets in upper 4 in $(10 \mathrm{~cm})$. Sample CA-15 from unit

Itstone, siliceous, calcareous, partly white stained; indurated. Some phosphatic pellets. Correlation unit S2. Sample CA-16 from unit

$\begin{array}{llll}2 & 0 & 0 & 61\end{array}$

70. Sandstone, very phosphatic, muddy. Grains, fine, subangular to subrounded, poorly sorted, randomly oriented; floating grains, as large as granule size. Framework, 17 percent quartz, 10 percent feldspar, 1 percent lithic fragments, and 38 percent phosphate; matrix, 33 percent clay minerals. Phosphatic framework, 42 percent pellets with noncentered inclusions and 16 percent pellets with centered inclusions of quartz, lithic fragments, feldspar, diatom fragments, zircon, and
Upper Miocene-Continued

Santa Margarita Formation-Continued

Upper phosphatic mudstone member-Continued Unit No.

Thickness

hematite, 35 percent struc-

tureless pellets, 5 percent fossil

fragments, and 4 percent

medium- to granule-size, sub-

rounded intraclasts. Pellets,

spheroids, regular to slightly

irregular; range from $0.08 \mathrm{~mm}$

to $0.45 \mathrm{~mm}$ in diameter; aver-

age $0.18 \mathrm{~mm}$, boundaries,

sharp; protruding grains, rare;

rims, siliceous, very rare; com-

pressed deformation, rare, and

nuclei commonly incipiently

calcitized. Framework grains in

early stages of altering to

sericite, common, and calcite,

rare. Samples CA-17,

F1208-20, and E1205-31 from unit

69. Porcellanite, indurated, brownstained. Sample CA-18 from unit

$\begin{array}{llll}3 & 6 & 1 & 7\end{array}$

68. Phosphorite and phosphatic mudstone. Upper half of unit, 35 percent phosphatic pellets; lower half, 55 percent. Sample CA-19 from this and underlying five units

67. Siltstone, bentonitic

66. Mudstone, brownish-gray to gray Phosphatic pellets, 15 percent(?)

Ft In $\mathrm{M} \mathrm{Cm}$ 3
3

65. Siltstone, slightly bentonitic, olive-gray. Phosphatic pellets, 30 percent

$\begin{array}{llll}0 & 6 & 0 & 15\end{array}$

64. Siltstone, porcelaneous, calcareous, light-gray. Phosphatic pellets, 5 percent

63. Bentonite and bentonitic siltstone

62. Siltstone, phosphatic, siliceous. Phosphatic pellets, 30 percent. Sample CA-20 from this and underlying unit

61. Phosphorite, sandy, gray. Phosphatic pellets, 60 percent. Correlation unit $\mathrm{P} 3$

60. Mudstone, siliceous. Phosphatic pellets; about 35 percent. Foraminiferal molds. Sample CA-21 from this and two underlying units

$\begin{array}{llll}0 & 6 & 0 & 15\end{array}$

$\begin{array}{llll}0 & 5 & 0 & 13\end{array}$

$\begin{array}{llll}1 & 2 & 0 & 36 \\ 0 & 10 & 0 & 25\end{array}$

59. Mudstone, siliceous. Phosphatic pellets, 25 percent

$\begin{array}{llll}0 & 10 & 0 & 25\end{array}$

58. Sandstone, light-gray, very fine grained; semifriable to friable. Phosphatic pellets, average 30 percent

$1 \quad 10 \quad 0 \quad 56$

57. Mudstone, slightly phosphatic, purplish-brown. Contains diatoms. Sample CA-22 from unit

56. Siltstone, siliceous, light-gray. Phosphatic pellets, 40 percent. 
Upper Miocene-Continued

Santa Margarita Formation-Continued

Upper phosphatic mudstone member-Continued Unit No.

$$
\begin{array}{lllll} 
& \multicolumn{4}{c}{\text { Thickness }} \\
\text { Ft } & \text { In } & M & C m \\
& & & & \\
0 & 11 & 0 & 28
\end{array}
$$

Sample CA-23 from this and underlying unit

55. Sandstone, very phosphatic, silty, muddy, light-gray. Grains, subangular to subrounded, poorly sorted, randomly oriented; floating grains, as large as coarse-size, rare. Framework, 21 percent quartz, 9 percent feldspar, 1 percent lithic fragments, 36 percent phosphate; matrix, 33 percent clay minerals. Phosphatic framework, 27 percent pellets with noncentered inclusions and 21 percent pellets with centered inclusions of quartz, feldspar, hematite, and diatom fragments, 42 percent structureless pellets, 5 percent compound pellets, 3 percent granules without grain inclusions, and 2 percent shell fragments. Pellets, spheroidal to ellipsoidal; average diameter $0.17 \mathrm{~mm}$; boundaries, mostly sharp; rims rarely calcareous; secondary rims commonly phosphatic; grains rarely protrude; peripheries slightly deformed rarely; nuclei and grains rarely incipiently calcitized. Sample F1208-21 from unit

54. Claystone, phosphatic, siliceous; laminations, faint, wavy. Grains, sand-size, subangular to subrounded, medium-sorted; long axis subparallel to laminae. Floating grains, as large as coarse-size, very rare. Framework, 6 percent quartz, and 2 percent feldspar; matrix 92 percent clay minerals. Phosphatic framework, noncentered pellets and structureless pellets very rare. X-ray diffraction analysis indicates matrix has abundant opal-CT and small amounts of montmorillonite and illite. Microfossils abundant; some with original skeletal material. Sample F1208-22 from unit. Sample CA-24 from this and underlying unit

53. Siltstone, bentonitic(?); moderately indurated

52. Claystone, silty, siliceous; laminations, crude, wavey. Grains, silt- and sand-size, angular to subangular, poorly sorted. Framework, 14 percent quartz, 7 percent feldspar, 1 percent
Upper Miocene-Continued

Santa Margarita Formation-Continued

Upper phosphatic mudstone member-Continued Unit No. Thickness

Ft $\quad$ In $\quad M \quad C m$

phosphate; matrix, 61 percent clay minerals, and 16 percent iron oxide (concentrated in patches as large as $6 \mathrm{~mm}$ across); accessory minerals, 1 percent, include hematite, muscovite, chlorite, magnetite, and glauconite. Phosphatic pellets, irregular ellipsoidal shape; range from 0.12 to $0.6 \mathrm{~mm}$ in diameter; boundaries fuzzy; grains protrude. Grains and pellet nuclei incipiently calcitized. Correlation unit S3. Sample F1208-23 from unit

51. Mudstone, phosphatic, pelletal, sandy, silty. Grains, angular to subrounded, poorly sorted, randomly oriented; floating grains, as large as coarse size, rare. Unit faintly laminated by pellet-rich (pellet supported) and pellet-poor zones. Veins rarely filled with hematite. Framework, 14 percent quartz, 9 percent feldspar, 27 percent phosphate; matrix, 47 percent clay minerals; accessory minerals, 3 percent. Phosphatic framework, 45 percent pellets with noncentered inclusions and 11 percent pellets with centered inclusions of quartz, feldspar, and diatom fragments, 23 percent structureless pellets, 6 percent compound pellets, 4 percent pebble fragments with grain inclusions, and 11 percent shell fragments Pellets, spheroids, regular to irregular; range from $0.08 \mathrm{~mm}$ to $0.50 \mathrm{~mm}$ in diameter; boundaries, sharp to fuzzy; rims, siliceous and secondarily phosphatic, rare; commonly flattened compressionally; protruding grains common; nuclei, incipiently calcitized and hematitized. $\mathrm{X}$-ray diffraction analysis indicates major component of matrix opal-CT and minor components montmorillonite and illite. Sample F1208-24 from unit

50. Claystone, siliceous, silty; poorly sorted. Similar to unit 52 . Sample CA-25 from unit

49. Sandstone, very fine grained, white; friable to semifriable. Phosphatic pellets, 30 percent. Sample CA-26 from unit

48. Porcellanite. Sample CA-27 from unit

$\begin{array}{lll}0 & 0 & 91\end{array}$ 
Upper Miocene-Continued

Santa Margarita Formation-Continued

Upper phosphatic mudstone member-Continued

Unit No.

\begin{tabular}{ccccc}
\multicolumn{5}{c}{ Thickness } \\
Ft & In & $M$ & $C m$ \\
& & & \\
& & & \\
& & & & \\
2 & 8 & 0 & 81 \\
2 & 10 & 0 & 86 \\
& & & & \\
& & & \\
0 & 6 & 0 & 15 \\
0 & 6 & 0 & 15 \\
0 & 1 & 0 & 3 \\
& & & \\
2 & 1 & 0 & 64 \\
& & & \\
0 & 10 & 0 & 25 \\
1 & 8 & 0 & 50
\end{tabular}

39. Sandstone, very phosphatic, feldspathic, very fine grained; friable to semifriable. Phosphatic pellets, dark-brown, 45 percent. Top, gradational; base, sharp. Correlation unit P4. Sample CA-31 from unit

38. Porcellanite, calcareous or dolomitic. Possibly faulted

37. Bentonite

36. Sandstone, very fine grained. Phosphatic pellets, about 10 percent

35. Siltstone and sandstone, feldspathic, very fine grained. Megafossils common

34. Porcellanite

32. Bentonite

31. Porcellanite, indurated. Some megafossils, round

30. Siltstone and sandstone, feldspathic, very fine grained. Phosphatic pellets, about 10 percen

$\begin{array}{llll}0 & 6 & 0 & 15\end{array}$

29. Sandstone, phosphatic, feldspathic, very fine grained. $\begin{array}{lllll}\text { Phosphatic pellets, } 40 \text { percent } & 0 & 7 & 0 & 18\end{array}$

28. Mudstone and siltstone, porcelaneous; about 10 percent phosphatic pellets

27. Bentonite. Sample CA-35 from unit

26. Siltstone, indurated. No phosphatic pellets

25. Siltstone, grades downward to very fine grained sandstone. Phosphatic pellets, 10 percent

24. Sandstone, light-gray, very fine

$\begin{array}{llll}1 & 2 & 0 & 36\end{array}$
Upper Miocene-Continued

Santa Margarita Formation-Continued

Upper phosphatic mudstone member-Continued Unit No.

Thickness

grained. Phosphatic pellets, 15 percent

Ft In $\mathrm{M} \quad \mathrm{Cm}$

23. Porcellanite and porcelaneous siltstone

$\begin{array}{llll}6 & 0 & 1 & 83\end{array}$

22. Bentonite, grades downward to sandstone, tan, bentonitic(?), slightly phosphatic

21. Sandstone, slightly phosphatic, fine-grained; indurated

$\begin{array}{llll}0 & 6 & 0 & 15\end{array}$ andstone, calcareous, slightly phosphatic, conglomeratic. Fossiliferous

$\begin{array}{llll}0 & 5 & 0 & 13\end{array}$

9. Siltstone

18. Bentonite

17. Siltstone and sandstone, siliceous, very fine grained. Thickness approximate

16. Siltstone, siliceous

15. Bentonite

14. Siltstone. Some phosphatic pellets

13. Bentonite

12. Siltstone and sandstone, very fine grained. Slightly phosphatic

11. Bentonite

10. Sandstone, very phosphatic, very fine grained. Phosphatic pellets, 50 percent. Very uncertain thickness

9. Limestone, white

$10 \quad 0 \quad 56$

$\begin{array}{llll}0 & 1 & 0 & 3\end{array}$

$\begin{array}{llll}1 & 4 & 0 & 41\end{array}$

$\begin{array}{llll}3 & 7 & 1 & 9\end{array}$

$\begin{array}{llll}0 & 11 & 0 & 28\end{array}$

trace

$\begin{array}{llll}4 & 2 & 1 & 27\end{array}$

8. Siltstone; phosphatic pellets, 10 percent

$\begin{array}{llll}0 & 5 & 0 & 13\end{array}$

$\begin{array}{llll}0 & 7 & 0 & 18\end{array}$

$\begin{array}{llll}0 & 2 & 0 & 5\end{array}$

$\begin{array}{llll}5 & 7 & 1 & 70\end{array}$

$\begin{array}{llll}1 & 8 & 0 & 51\end{array}$

trace

$\begin{array}{llll}1 & 1 & 0 & 33\end{array}$

trace

$\begin{array}{llll}2 & 0 & 0 & 61\end{array}$ trace grained. Phosphatic pellets, 40 percent

$\begin{array}{llll}2 & 8 & 0 & 81\end{array}$

$\begin{array}{llll}0 & 7 & 0 & 18\end{array}$

$\begin{array}{llll}0 & 4 & 0 & 10\end{array}$

6. Porcellanite

5. Siltstone, porcelaneous

4. Sandstone, very fine grained. Phosphatic pellets, 10 percent

3. Bentonite

2. Siltstone; slightly phosphatic $\quad \begin{array}{lllll}2 & 8 & 0 & 81\end{array}$

1. Bentonite(?)

Total measured thickness of upper phosphatic mudstone member

$\begin{array}{llll}0 & 10 & 0 & 25\end{array}$

$\begin{array}{llll}1 & 11 & 0 & 58\end{array}$

$\begin{array}{llll}1 & 1 & 0 & 33\end{array}$

$\begin{array}{llll}1 & 7 & 0 & 48\end{array}$ trace

trace

$\begin{array}{llll}192 & 8 & 58 & 72\end{array}$

\section{Trench 297}

(Measured by H. D. Gower, 1964; E and F numbered samples described petrographically by $\mathrm{T}$. L. Vercoutere)

LOCATION: NW1/4NW1/4 sec. 35 , T. 10 N., R. 27 W. (S.S.B. \& M.) in the New Cuyama, California quadrangle ATTITUDE OF BEDDING: Approximately N. $85^{\circ} \mathrm{W} .65^{\circ} \mathrm{S}$

TREND OF TRENCH: Approximately north-south. Due to complex structure, thickness and attitude of stratigraphic units $126-131$ is approximate.

Upper Miocene:

Santa Margarita Formation:

Upper phosphatic mudstone member: Unit No.

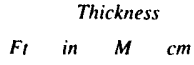

131. Siltstone, grades downward into very fine grained sandstone or 
Upper Miocene-Continued

Santa Margarita Formation-Continued

Upper phosphatic mudstone member-Continued Unit No.

siltstone, light-gray. Phosphatic pellets, about 2 percent. Lower part, fossiliferous. Attitude, $\mathrm{N}$. $55^{\circ}$ E. $40^{\circ}$ SE., good

$$
\text { Thickness }
$$$$
\text { Ft In } \quad M \quad C m
$$

30. Bentonite and bentonitic siltstone; dark-greenish-gray to lightolive-gray

129. Siltstone and very fine grained sandstone, light-gray. Phosphatic pellets, about 3 percent. Thickness uncertain

128. Sandstone, very fine grained, or siltstone, light-gray. Unit contains about 15 percent phosphatic pellets and small nodules as large as $1 / 4$ in. $(0.6$ $\mathrm{cm})$. Megafossils. Unit looks like a till megascopically because of poor sorting of phosphatic pellets and nodules

127. Bentonite, bentonitic siltstone, and very fine grained sandstone; poorly sorted. Unit contains several percent of coarse quartz grains, phosphatic pellets, and nodules Possible fault zone at top. Thickness approximate

126. Sandstone, very fine grained, and siltstone. Unit contains about 10 percent phosphatic pellets and small nodules. Pectens, original shells, abundant. Lower 5 in. $(13 \mathrm{~cm})$ of unit, silty. Attitude: N. $8^{\circ}$ E. $30^{\circ}$ SE. at top (poor); N. $15^{\circ}$ W. $29^{\circ}$ NE. at base (poor)

125. Siltstone, light-gray. Fish scales, common. Attitude: N. $55^{\circ}$ E. $40^{\circ} \mathrm{SE}$. (good)

124. Bentonite

123. Siltstone, light-gray

122. Bentonite

121. Siltstone, light-gray to light-tan

120. Bentonite

119. Siltstone, slightly phosphatic, light-gray. Megafossils scattered. Base, coarser grained

118. Bentonite and gypsum

117. Siltstone to very fine grained sandstone, light-gray. Phosphatic pellets, about 15 percent, more abundant at base

116. Gypsum and bentonite

$\begin{array}{llll}2 & 0 & 0 & 6\end{array}$

115. Sandstone, silty, light-gray, very fine grained. Phosphatic pellets, about 15 percent, most abundant at base

114. Bentonite $\begin{array}{llll}1 & 11 & 0 & 58\end{array}$ trace $\begin{array}{llll}2 & 4 & 0 & 71\end{array}$

$05+013+$

$\begin{array}{llll}0 & .4 & 0 & .9\end{array}$

$\begin{array}{llll}0 & 7 & 0 & 18\end{array}$

trace

$\begin{array}{llll}1 & 5 & 0 & 43\end{array}$

$\begin{array}{llll}0 & 1 & 0 & 2\end{array}$

$\begin{array}{llll}2 & 0 & 0 & 61\end{array}$

$\begin{array}{llll}0 & .2 & 0 & .6\end{array}$
113. Sandstone, light-gray, very fine grained. Phosphatic pellets, 20 percent; some nodules
Upper Miocene-Continued

Santa Margarita Formation-Continued

Upper phosphatic mudstone member-Continued Unit No.

112. Bentonite and gypsum Fl In $\quad M \quad C m$ trace

111. Sandstone, silty, light-gray, very fine grained. Phosphatic pellets, about 20-25 percent

110. Siltstone, siliceous, and porcellanite

$\begin{array}{llll}2 & 4 & 0 & 71\end{array}$

$\begin{array}{llll}0 & 7 & 0 & 18\end{array}$

109. Porcellanite; phosphatic pellets, less than 10 percent

108. Gypsum and bentonite

107. Porcellanite, indurated. Phosphatic pellets, rare '

$\begin{array}{llll}2 & 6 & 0 & 76\end{array}$

$\begin{array}{llll}0 & .2 & 0 & .6\end{array}$

$\begin{array}{llll}0 & 8 & 0 & 20\end{array}$

106. Siltstone, sandy, siliceous. Quartz grains, coarse, common. Phosphatic pellets, about 25 percent, most abundant at base. Megafossils common

$\begin{array}{llll}0 & 11 & 0 & 28\end{array}$

105. Siltstone, siliceous light-gray. Fish scales very abundant. Base of unit, up dip, appears phosphatic; may be faulted

104. Bentonite

103. Siltstone, siliceous. Fish scales, very abundant

$\begin{array}{lll}0 & 0 & 30\end{array}$

$0,1 \quad 0 \quad 3$

$\begin{array}{llll}1 & 8 & 0 & 51\end{array}$

102. Sandstone, very fine grained, and sandy siltstone. Phosphatic pellets, 50 percent

$\begin{array}{llll}1 & 4 & 0 & 41\end{array}$

101. Bentonite and gypsum

$\begin{array}{llll}0 & .2 & 0 & .6\end{array}$

100. Sandstone, very fine to finegrained, and siltstone, sandy, light-gray at top, brown at base. Phosphatic pellets, 50 percent

99. Siltstone, siliceous

\section{STRATIGRAPHIC UNITS 99 THROUGH 103 ARE REPEATED BY} FOLDING

98. Sandstone, fine-grained, and siltstone, phosphatic, light-gray. Phosphatic pellets, 40 percent. Correlation unit P1. Sample Pl-297 from unit

97. Siltstone, siliceous; moderately indurated; highly fractured. Two, thin bentonite beds $2.3 \mathrm{ft}$ $(70 \mathrm{~cm})$ below top and $1 \mathrm{ft}(30$ $\mathrm{cm})$ above base. Porcellanite, indurated, 5 in. $(13 \mathrm{~cm})$ bed containing abundant foraminiferal molds $2 \mathrm{ft}(51 \mathrm{~cm})$ above base; $1 \mathrm{ft}(30 \mathrm{~cm})$ bed at base. Thickness approximate

96. Bentonite

95. Siltstone, porcelaneous. Base, phosphatic, 20 percent pellets in lower 2 in. $(5 \mathrm{~cm})$

94. Sandstone, phosphatic, brown, poorly sorted; 35 percent pellets; phosphatized fossils small

93. Siltstone, siliceous. Mollusk fragments, abundant, small 
Upper Miocene-Continued

Santa Margarita Formation-Continued

Upper phosphatic mudstone member-Continued Unit No.

\section{Porcellanite \\ 91. Bentonite}

90. Porcellanite

89. Phosphorite, sandy, brown; friable to moderately indurated. Phosphatic pellets, 70 percent. Megafossils, rare, at top. Correlation unit $\mathrm{P} 2$ '. Sample P2-297 from unit

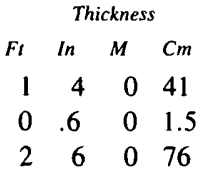

88. Siltstone, siliceous, sandy. Phosphatic pellets, 10 percent, in lower half. Correlation unit S1

87. Grainstone and calcareous mudstone, light-gray; very sharp contact. Grainstone, very phosphatic, very poorly sorted. Contains 14 percent quartz and feldspar grains, subangular to rounded, ranging from 0.07 to $0.80 \mathrm{~mm} ; 6$ percent shell fragments, calcareous, as long as 4 $\mathrm{mm} ; 6$ percent shell fragments, phosphatic, as long as $2 \mathrm{~mm}$, partially replaced by silica (common); 5 percent pellets, spheroidal, ranging from 0.25 $\mathrm{mm}$ to $0.60 \mathrm{~mm}$ in diameter, with centered (rare) and noncentered (common) inclusions of quartz, feldspar, diatom fragments, and foraminifers; 10 percent pellets, spheroidal, structureless, partially replaced by silica (rare), rarely rimmed sharply with iron-oxide; 16 percent intraclasts with inclusions of pellets, carbonate shell fragments, iron oxide, mineral grains, foraminiferal tests, and diatom fragments; and 25 percent nodules without inclusions; shape, variable, mostly elongated, ranging from 0.03 to $3 \mathrm{~mm}$ in diameter; matrix of 25 percent carbonate minerals and 1 percent iron oxide. Mudstone, calcareous, slightly phosphatic; contains approximately 5 percent subangular silt to very fine sand size fragments, 10 percent foraminiferal tests infilled with sparry calcite, (some partially silicified), 3 percent phosphatic pellets, spheroidal, structureless, average $0.10 \mathrm{~mm}, 1$ percent phosphatized shell fragments, less than $1 \mathrm{~mm}$ long; matrix of 3 percent iron oxide and 78 percent micrite (partly cement). Base sharp, very irregular. Sample F1208-50 from unit
Upper Miocene-Continued

Santa Margarita Formation-Continued

Upper phosphatic mudstone member-Continued Unit No.

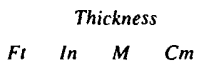

86. Sandstone, calcareous, siliceous, white; indurated. Some phosphatic pellets. Coquina at top

85. Siltstone, sandy, siliceous, lightgray to brown. Phosphatic pellets, about 15 percent. Foraminiferal casts abundant at top. Unit grades into overlying unit

84. Siltstone, siliceous

83. Bentonite

82. Siltstone, siliceous

81. Bentonite

80. Siltstone, siliceous, or porcellanite; somewhat slickensided

$\begin{array}{llll}0 & 4 & 0 & 10\end{array}$

79. Bentonite

78. Siltstone, siliceous

77. Bentonite

76. Siltstone, siliceous. Sandy and phosphatic at base

75. Mudstone, siliceous, moderately phosphatic. Phosphatic pellets, 15 percent

Fi In $\mathrm{M} \quad \mathrm{Cm}$

74. Mudstone, silty to sandy, moderately phosphatic. Grains, very fine, subangular to subrounded, poorly sorted, randomly oriented; floating grains, as large as medium-size, rare; commonly altered to sericite and rarely altered to calcite. Framework, 17 percent quartz, 9 percent feldspar, 1 percent chert, 19 percent phosphate; matrix, 52 percent clay minerals; accessory minerals, 2 percent include muscovite, magnetite, hematite, chlorite, and zircon. Phosphatic framework, 16 percent pellets with noncentered inclusions and 26 percent pellets with centered inclusions of quartz, feldspar, and diatom fragments; 47 percent structureless pellets; 11 percent fish bones and shell fragments, less than $1 \mathrm{~mm}$ across. Pellets, spheroidal, approximately $0.18 \mathrm{~mm}$ in diameter; boundaries, sharp to fuzzy; rims commonly siliceous; protruding grains very rare; very little peripheral deformation; nuclei rarely incipiently calcitized. Sample F1208-42 from unit

73. Mudstone, sandy, moderately phosphatic; thickly laminated. Grains, fine, subangular to subrounded, poorly sorted, randomly oriented. Framework, 19 percent quartz, 7 percent feldspar, and 18 percent phos- $\begin{array}{llll}0 & 5 & 0 & 13\end{array}$

$\begin{array}{llll}0 & 2 & 0 & 5\end{array}$

$\begin{array}{llll}0 & 4 & 0 & 10\end{array}$ trace

$\begin{array}{llll}2 & 8 & 0 & 81\end{array}$

$\begin{array}{llll}1 & 0 & 0 & 30\end{array}$ 
Upper Miocene-Continued

Santa Margarita Formation-Continued

Upper phosphatic mudstone member-Continued Unit No.

Thickness

FI In $\quad \mathrm{M} \quad \mathrm{Cm}$

phate; matrix, 50 percent clay

minerals and 4 percent iron

oxide; accessory minerals, 2

percent; include glauconite,

muscovite, chlorite, magnetite,

and zircon. Phosphatic frame-

work, 28 percent pellets with

noncentered inclusions and 22

percent pellets with centered

inclusions of quartz, feldspar,

muscovite, magnetite, zircon,

shell fragments (very rare), and

diatom fragments, 49 percent

structureless pellets, and 1 per-

cent shell fragments, $0.5 \mathrm{~mm}$

long. Pellets, spheroids, reg-

ular to slightly irregular; range

from 0.08 to $0.45 \mathrm{~mm}$ in

diameter; average diameter

$0.20 \mathrm{~mm}$; boundaries, sharp,

rarely fuzzy; rims, iron oxide,

rare; periphery commonly

deformed slightly; nuclei rarely

incipiently calcitized. Sample

F1208-51 from upper half of unit

72. Siltstone, bentonitic(?) in places, olive-gray; weakly indurated

71. Sandstone, very fine grained, poorly sorted. Phosphatic pellets, 10 percent. Megafossils, abundant. Lower half, calcareous

70. Siltstone, slightly bentonitic

69. Bentonite

68. Siltstone, slightly bentonitic

67. Bentonite

66. Siltstone, siliceous

65. Bentonite, and bentonitic siltstone

64. Siltstone, sandy, light-gray. Phosphatic pellets, 10 percent

63. Sandstone, brown to tan to gray,

very fine to fine grained. Phosphatic pellets, 45 percent.

Large mammal(?) bones abundant. Base, sharp, irregular

62. Mudstone, calcareous, very slightly phosphatic. Grains, subangular silt, and fine to very fine sand, poorly sorted.

Framework, 4 percent quartz, 2 percent feldspar, 1 percent phosphatic pellets, 10 percent recrystallized shell fragments including diatom frustules; matrix, 82 percent carbonate; accessory minerals, 1 percent, include hematite, glauconite, and magnetite. Pellets, spheroids, regular to irregular; range from $0.09 \mathrm{~mm}$ to $0.21 \mathrm{~mm}$ in diameter; structureless or with inclusions of quartz or diatom
Upper Miocene-Continued

Santa Margarita Formation-Continued

Upper phosphatic mudstone member-Continued

Unit No.

Thickness

Ft In $M \quad C m$

fragments; boundaries fuzzy.

Few foraminiferal tests present.

Correlation unit S2. Sample

E1204-1 from unit

$\begin{array}{llll}2 & 7 & 0 & 79\end{array}$

61. Sandstone, silty, siliceous; very fine grained, poorly sorted. Phosphatic pellets, 15 percent

60. Siltstone, siliceous, very diatomaceous. Density fairly low. Fossil casts, abundant weathered

$\begin{array}{llll}2 & 0 & 0 & 61\end{array}$

59. Phosphorite, light-gray to brown. Phosphatic pellets, 50 percent in upper half of unit; 70 percent in lower half

120036 .

58. Siltstone, bentonitic, and shale, siliceous. Bentonite in lower 2 in. $(5 \mathrm{~cm})$ of base

$1 \quad 6 \quad 0 \quad 46$

$\begin{array}{llll}0 & 7 & 0 & 18\end{array}$

57. Siltstone, siliceous. Unit sheared. Phosphatic pellets, 20 percent. May contain bentonite

$1 \quad 11 \quad 0 \quad 58$

56. Phosphorite, tan, friable. Phosphatic pellets, 70 percent. Megafossils, poorly preserved, rare. Correlation unit P3. Sample P3-297 from unit

55. Siltstone, siliceous. Phosphatic pellets, 5 percent

54. Mudstone, siliceous. Phosphatic pellets, 20 percent

53. Siltstone, siliceous, slightly phosphatic

52. Mudstone. Phosphatic pellets, 20 percent. Thickness uncertain

51. Porcellanite, diatomaceous, slightly phosphatic. Density, low. Thickness uncertain

50. Phosphorite, very sandy, muddy, light-tan; friable to semifriable. Phosphatic pellets, 70 percent. Quartz grains, coarse, abundant

49. Porcellanite

48. Mudstone, phosphatic, sandy, pelletal. Grains, fine, subangular to subrounded, poorly sorted, randomly oriented; floating grains as large as granule size. Partly grain supported. Phosphatic pebble fragments as large as $2.5 \mathrm{~mm}$. Framework grains commonly altered to sericite or rarely calcite. Framework, 18 percent quartz, 8 percent feldspar, and 31 percent phosphatic; matrix, 40 percent clay minerals and 2 percent carbonate minerals, accessory minerals, 1 percent, include chlorite, magnetite, zircon, hematite, and muscovite. Iron oxide commonly concentrated in approximately $1 \mathrm{~mm}$ $\begin{array}{llll}1 & 5 & 10 & 43\end{array}$

$\begin{array}{llll}2 & 7 & 0 & 79\end{array}$

$1 \quad 1 \quad 0 \quad 33$

$\begin{array}{llll}1 & 7 & 0 & 48\end{array}$

$\begin{array}{llll}1 & 0 & 0 & 30\end{array}$

$140 \quad 41$

$\begin{array}{llll}0 & 7 & 0 & 18\end{array}$

$\begin{array}{llll}2 & 2 & 0 & 66\end{array}$ 
Upper Miocene-Continued

Santa Margarita Formation-Continued

Upper phosphatic mudstone member-Continued Unit No.

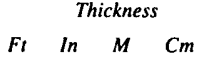

patches. Phosphatic framework, 30 percent pellets with noncentered inclusions and 16 percent pellets with centered inclusions of quartz, feldspar, zircon, and diatom fragments; 25 percent structureless pellets, 3 percent compound pellets, 10 percent nodules with grain inclusions (including grapestone), 3 percent nodules without grain inclusions, and 13 percent shell and fish-bone fragments less than $1 \mathrm{~mm}$ long. Pellets, spheroids, regular to irregular; range from $0.08 \mathrm{~mm}$ to $0.40 \mathrm{~mm}$ in diameter; average diameter $0.20 \mathrm{~mm}$; boundaries, very sharp; protruding grains rare; commonly slightly deformed peripherally at contacts with other pellets or grains; nuclei incipiently calcitized. Sample F1208-48 from unit. Plate $6 N$ from unit

47. Claystone, slightly phosphatic, silty; laminated, crudely lenticular patches of disseminated hematite parallel to laminae.

Grains, angular to subrounded, poorly sorted, subparallel long axes; floating grains, as large as medium-size rare. Grains rarely partially calcitized; quartz grains rarely opalized. Framework, 11 percent quartz, 11 percent feldspar, 5 percent phosphate; matrix, 68 percent clay minerals, 3 percent iron oxide, 2 percent apatite; accessory minerals include glauconite, zircon, muscovite, and chlorite. Phosphatic framework, 66 percent structureless pellets, 24 percent pellets with noncentered inclusions of quartz and diatom fragments, 5 percent nodules, and 5 percent shell fragments. Pellets, spheroidal to pear-shaped; range from 0.06 to $0.25 \mathrm{~mm}$ in diameter; average $0.13 \mathrm{~mm}$; boundaries fuzzy to sharp, and protruding grains rare. Sample F1208-47 from unit

46. Bentonite

Fault zone; small, little displacement; N. $45^{\circ} \mathrm{W} .78^{\circ} \mathrm{SW}$. Questionable correlation of bentonite bed (stratigraphic unit 46) across fault.

45. Porcellanite, and porcelaneous siltstone; contains fossils. Cor-
Upper Miocene-Continued

Santa Margarita Formation-Continued

Upper phosphatic mudstone member-Continued Unit No.

relation unit S3

Thickness

Ft In $M \quad \mathrm{Cm}$

udstone, sandy, slightly phosphatic. Grains, fine, subangular to subrounded, poorly sorted; long axis oriented subparallel to crudely laminated sandy mudstone layers and mudstone layers. Framework, 16 percent quartz, 8 percent feldspar, and 9 percent phosphate; matrix, 56 percent clay minerals, 1 percent carbonate minerals, and 9 percent iron oxide, accessory minerals, 1 percent, include chlorite, magnetite, zircon, and muscovite. Phosphatic framework, 22 percent pellets with noncentered inclusions and 20 percent pellets with centered inclusions of quartz, feldspar, chlorite and diatom fragments, 47 percent structureless pellets, 8 percent shell fragments less than $1 \mathrm{~mm}$ long, and 5 percent compound pellets. Pellets, spheroidal; average diameter $0.17 \mathrm{~mm}$; boundaries sharp to fuzzy; many rimmed with secondary phosphate and rarely rimmed with silica; nuclei rarely secondarily calcitized. Commonly stained with hematite. Sample F1208-46 from unit

43. Mudstone, phosphatic, sandy; siliceous matrix; fractured. Grains fine to very fine grained, angular to subrounded, medium-sorted; floating grains, as large as coarse size, rare; grains commonly incipiently calcitized, especially in fractures. Framework, 15 percent quartz, 11 percent feldspar, and 35 percent phosphate; matrix, 32 percent clay minerals, and 2 percent carbonate minerals; accessory minerals, 1 percent, include chlorite, zircon, magnetite, and hematite.

Phosphatic framework, 25 percent pellets with noncentered inclusions and 22 percent pellets with centered inclusions of quartz, feldspar, and diatom fragments, 40 percent structureless pellets, 4 percent compound pellets, 6 percent nodules without inclusions, and 3 percent shell fragments less than $1 \mathrm{~mm}$ long. Pellets, spheroids, regular to slightly 
Upper Miocene-Continued

Santa Margarita Formation-Continued

Upper phosphatic mudstone member-Continued Unit No.

irregular, range from $0.12 \mathrm{~mm}$ to $0.28 \mathrm{~mm}$ in diameter; boundaries, sharp; commonly rimmed with secondary phosphate; commonly slightly deformed peripherally at contacts with other pellets. Oolitic structure, very rare. Sample E1203-22A from unit

42. Siltstone, porcelaneous

41. Sandstone, very fine grained. Phosphatic pellets, 20 percent. Some burrows(?)

$\begin{array}{llll}1 & 4 & 0 & 41\end{array}$

40. Siltstone, porcelaneous

$\begin{array}{llll}0 & 2 & 0 & 5\end{array}$

39. Sandstone, very fine grained, and siltstone

$\begin{array}{llll}0 & 5 & 0 & 13\end{array}$

38. Porcellanite, and porcelaneous siltstone; locally phosphatic

37. Phosphorite, with irregular, slightly phosphatic, mudstone laminations. Phosphatic pellets, 60 percent. Upper 6 in. $(15 \mathrm{~cm})$ of unit, phosphatic porcellanite, 30 percent phosphatic pellets. Basal 2 in. ( 5 $\mathrm{cm}$ ) of unit, sandy, friable

36. Porcellanite, phosphatic, 30 percent phosphatic pellets

$\begin{array}{llll}3 & 5 & 1 & 4\end{array}$

$\begin{array}{llll}1 & 1 & 0 & 33\end{array}$

$\begin{array}{llll}0 & 6 & 0 & 15\end{array}$

35. Phosphorite, sandy, fine- to very fine grained. Small pebbles, common. Phosphatic pellets, medium-sorted. Grains, angular to subrounded; floating grains, as large as coarse size, common. Framework, quartz (common), feldspar (common), phosphate (abundant); matrix, siliceous clay minerals (common), carbonate (rare); accessory minerals include chlorite, zircon, magnetite, and muscovite. Phosphatic framework, pellets with centered and noncentered inclusions of quartz, feldspar, diatom fragments, and very rarely zircon, structureless pellets, ooliths compound pellets, and shell fragments. Pellets, spheroids, regular to slightly irregular, range from $0.12 \mathrm{~mm}$ to 0.30 $\mathrm{mm}$ in diameter; boundaries, sharp (abundant); rims, siliceous (rare); protruding and intruding grains (common); slightly deformed peripherally (common). Upper and middle part of unit, small-scale crossbedding and burrows; much of basal unit, reddishbrown, friable. Mammal(?) bones common at base. Some distinct burrows in underlying

Upper Miocene-Continued

Santa Margarita Formation-Continued

Upper phosphatic mudstone member-Continued Unit No.

Thickness

unit. Sample E1203-18 from unit. Phosphatic oolith (pl. 6 $H)$ and phosphatic mudstone intraclasts (pl. $6 L$ ) from unit

34. Porcellanite, phosphatic

33. Bentonite

Ft. In $\quad M \quad C m$

32. Porcellanite, diatomaceous; very light weight. Some flattish clams and fish scales. Indistinct phosphatic pellets forming(?) in upper part. Correlation unit S4

31. Sandstone, very fine to finegrained; friable to semifriable. Phosphatic pellets, 20 percent

30. Porcellanite. Fragments of phosphatic sandstone, spherical, irregularly rounded, as much as 3 in. $(8 \mathrm{~cm})$ long

$\begin{array}{llll}1 & 0 & 0 & 30\end{array}$

$\begin{array}{llll}1 & 0 & 0 & 30\end{array}$

$\begin{array}{llll}0 & .6 & 0 & 1.5\end{array}$

29. Bentonite(?)

28. Porcellanite

27. Sandstone and siltstone. Phosphatic pellets, 25 percent. Base, sharp, irregular. Correlation unit P4. Sample P4-297 from unit

26. Porcellanite, slightly calcareous, white, indurated. Fossil molds, very abundant

$\begin{array}{llll}1 & 11 & 0 & 58\end{array}$

25. Bentonite

24. Mudstone, phosphatic, pelletal; siliceous matrix. Grains, angular to subangular, poorly sorted, randomly oriented. Framework, 8 percent quartz, 4 percent feldspar, 25 percent phosphate; matrix, 59 percent clay minerals, and 4 percent iron oxide. Phosphatic framework, 38 percent pellets with noncentered grain inclusions and 4 percent pellets with centered grain inclusions of quartz, feldspar, zircon, chert, and diatom debris, 28 percent structureless pellets, 4 percent compound pellets, 8 percent nodules with grain inclusions, 4 percent structureless nodules, and 16 percent shell fragments as long as $4 \mathrm{~mm}$. Pellets, spheroids, regular to irregular, range from $0.10 \mathrm{~mm}$ to 0.35 $\mathrm{mm}$ in diameter; boundaries, sharp; protruding grains common; compressional flattening common; nuclei rarely incipiently calcitized. Many pellets concentrated in burrows with an iron-oxide matrix. Few megafossils in unit. Phosphorite pebble, pelletal, $1 / 4$ in. $(6 \mathrm{~mm})$ rare. Sample E1203-16 $\begin{array}{llll}0 & 11 & 0 & 28\end{array}$

$\begin{array}{llll}0 & 10 & 0 & 25\end{array}$

$\begin{array}{llll}0 & 5 & 0 & 13\end{array}$

$\begin{array}{llll}0 & .1 & 0 & .3\end{array}$

$\begin{array}{llll}0 & 10 & 0 & 25\end{array}$

trace 
Upper Miocene-Continued

Santa Margarita Formation-Continued

Upper phosphatic mudstone member-Continued Unit No.

from unit

23. Sandstone, very fine grained, and siltstone, slightly phosphatic. Contains megafossils

22. Siltstone, siliceous

21. Bentonite

20. Siltstone, siliceous

19. Siltstone, siliceous. Phosphatic pellets, 3 percent

$\begin{array}{llll}1 & 5 & 0 & 43\end{array}$

$\begin{array}{llll}2 & 10 & 0 & 86\end{array}$

$\begin{array}{llll}0 & .6 & 0 & 1.5\end{array}$

160046

$\begin{array}{llll}2 & 5 & 0 & 74\end{array}$

18. Sandstone, very fine to finegrained, friable. Flame structures indicate sand moved from north to south. Phosphatic pellets, 10 percent phosphatic in upper $2 \mathrm{ft}(61 \mathrm{~cm}) ; 15$ percent in lower $1 \mathrm{ft}(30 \mathrm{~cm})$. Chert nodules near base. Base, irregular. Thickness uncertain for this unit and nine underlying units; may be some faulting

17. Siltstone, and minor porcelaneous siltstone. Some phosphatic pellets, fine-grained, pitted

16. Bentonite, and bentonitic siltstone. Fault zone

15. Siltstone, siliceous, slightly phosphatic at base

14. Siltstone, sandy. Phosphatic pellets, 2 percent

13. Bentonite

12. Porcellanite. Phosphatic pellets, 5 percent

11. Sandstone, very fine grained. Phosphatic pellets, 25 percent. Lower part, broken and sheared, possibly faulted

10. Sandstone, fine-grained. Phosphatic pellets, less than or equal to 10 percent

9. Sandstone, very fine grained. Phosphatic pellets, 5 percent

8. Claystone, slightly phosphatic; faintly laminated. Grains, sand-size, angular to subangular, poorly sorted. Framework, 12 percent quartz, 4 percent feldspar, 7 percent phosphate; matrix, 76 percent clay minerals; accessory minerals, 1 percent, include chlorite, magnetite, zircon, and muscovite. Phosphatic framework, 30 percent pellets with noncentered inclusions and 30 percent pellets with centered inclusions of quartz, feldspar, hematite, and diatom fragments, 39 percent structureless pellets, and 1 percent shell fragments less than $1 \mathrm{~mm}$ long. Pellets, spheroids, regular to slightly irregular; range from $0.10 \mathrm{~mm}$ to $0.30 \mathrm{~mm}$ in diameter;
Thickness

Ft In $M \quad \mathrm{Cm}$

$\begin{array}{llll}0 & 11 & 0 & 28\end{array}$

Upper Miocene-Continued

Santa Margarita Formation-Continued

Upper phosphatic mudstone member-Continued Unir No.

boundaries, sharp to fuzzy; protruding grains rare; rarely rimmed with secondary phosphate; nuclei rarely incipiently calcitized; interior region rarely stained with iron oxide. Sample E1203-10 from unit

7. Sandstone, very fine grained. Upper half of unit brown, friable; base, white to light-gray. Phosphatic pellets, about 40 percent in upper 6 in. $(15 \mathrm{~cm})$; slightly phosphatic in lower part

6. Bentonite

5. Porcellanite, white to light-greenish-gray. Phosphatic pellets, 5 percent, mostly very fine grained

$2 \quad 2066$ $\begin{array}{llll}3 & 0 & 0 & 91\end{array}$

$\begin{array}{llll}6 & 4 & 1 & 93\end{array}$

$\begin{array}{llll}0 & 8 & 0 & 20\end{array}$

$\begin{array}{llll}1 & 7 & 0 & 48\end{array}$

$\begin{array}{llll}1 & 0 & 0 & 30\end{array}$

$\begin{array}{llll}0 & 4 & 0 & 10\end{array}$

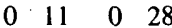

$\begin{array}{llll}0 & 11 & 0 & 28\end{array}$

12036

$\begin{array}{llll}1 & 2 & 0 & 36\end{array}$
4. Siltstone, sandy, brown. Phosphatic pellets, 5 percent fi $\ln M \quad M \quad(m$

Sandstone, brown, fine-grained, friable to semifriable, sheared. Phosphatic pellets, 10 percent

2. Sandstone, light-gray, finegrained, friable. Phosphatic pellets, about 10 percent

1. Sandstone, fine-grained, lightgray. Not measured

Total measured thickness of the upper phosphatic mudstone member:

\section{Trench 299}

(Measured by H. D. Gower, 1964)

LOCATION: NE $1 / 4$ NE $1 / 4$ sec. 12, T. 9 N., R. 27 W. (S.B.B. \& M.); $1,486,800 \mathrm{ft} \mathrm{W}$. and $507,400 \mathrm{ft} \mathrm{N}$., California plane coordinate system; in the New Cuyama, California, quadrangle.

ATTITUDE OF BEDDING: approximately N. $40^{\circ} \mathrm{W}$, near vertical to slightly overturned

Trench 299 is a double trench. Trenches trend approximately N. $50^{\circ} \mathrm{E}$. and are offset approximately $75 \mathrm{ft}(23 \mathrm{~m})$ along strike. Upper 107 stratigraphic units were measured in the eastern trench; lower 32 stratigraphic units were measured in the western trench.

\section{Eastern Trench}

Upper Miocene:

Santa Margarita Formation:

Upper phosphatic mudstone member: Unit No.

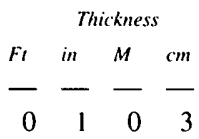

138. . Bentonite

137. Porcellanite and siltstone, calcareous, thin-bedded, indurated. White-stained weathered surface

136. Sandstone, reddish-brown, very fine grained. Phosphatic pellets, 10 percent 
Upper Miocene-Continued

Santa Margarita Formation-Continued

Upper phosphatic mudstone member-Continued Unit No.

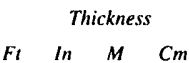

135. Porcellanite and siltstone, calcareous, thin-bedded, indurated. White-stained weathered surface

134. Siltstone, bentonitic, and bentonite

133. Siltstone and mudstone. Phosphatic pellets, 10 percent

132. Sandstone, orange-brown, very fine grained; friable. Phosphatic pellets, 10 percent

131. Bentonite, siltstone, and siliceous siltstone; very friable

130. Siltstone, siliceous, locally phosphatic; moderately indurated. Fracture, blocky

129. Mudstone, siliceous. Phosphatic pellets, 30 percent

128. Bentonite

127. Siltstone, siliceous

126. Bentonite

125. Siltstone, siliceous

124. Phosphorite; phosphatic pellets, 70 percent

123. Bentonite, phosphatic

122. Phosphorite; phosphatic pellets, 75 percent

121. Siltstone and siliceous siltstone

120. Phosphorite. Phosphatic pellets, 80 percent in unit except upper 4 in. $(10 \mathrm{~cm})$ where it is 40 percent. Correlation unit $\mathrm{P} 1$

119. Siltstone, and siliceous siltstone. Phosphatic pellets, about 5 percent

$\begin{array}{llll}2 & 0 & 6 & 61\end{array}$

118. Siltstone, bentonitic, and siliceous siltstone; weakly indurated

117. Porcellanite, indurated

116. Bentonite, siltstone, and weathered calcareous siltstone weakly indurated. Some phosphatic pellets. Megafossils, rare

115. Porcellanite, indurated

114. Siltstone, possibly bentonitic, partly bentonite and weathered calcareous siltstone; weakly indurated

$\begin{array}{llll}3 & 6 & 1 & 7\end{array}$

113. Porcellanite. Phosphatic pellets, 40 percent in lower 4 in. ( 10 $\mathrm{cm}$ )

112. Phosphorite, sandy, brown, very fine grained; friable to semifriable. Phosphatic pellets, 70 percent. Correlation unit P2

111. Porcellanite, possibly calcareous, indurated. Correlation unit S1

110. Porcellanite, broken, with thin, irregular lenses of sandstone and phosphatic sandstone

109. Sandstone, pale-yellowish-gray; very fine grained; very friable.

$\begin{array}{llll}0 & 11 & 0 & 28\end{array}$

$\begin{array}{llll}0 & 10 & 0 & 25\end{array}$

trace

$\begin{array}{llll}0 & 11 & 0 & 28\end{array}$

$\begin{array}{llll}0 & 8 & 0 & 20\end{array}$

$\begin{array}{llll}0 & 6 & 0 & 15\end{array}$

$\begin{array}{llll}0 & 8 & 0 & 20\end{array}$

$\begin{array}{llll}2 & 2 & 0 & 66\end{array}$
Upper Miocene-Continued

Santa Margarita Formation-Continued

Upper phosphatic mudstone member-Continued Unit No.

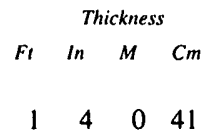

$\begin{array}{llll}1 & 4 & 0 & 41\end{array}$

Phosphatic pellets, about 20 percent. Thickness uncertain

108. Bentonite, bentonitic siltstone, porcellanite, and siliceous siltstone. Broken zone

$\begin{array}{llll}6 & 7 & 2 & 1\end{array}$

107. Mudstone, porcelaneous; indurated. Phosphatic pellets, 5 percent

$\begin{array}{llll}0 & 7 & 0 & 18\end{array}$

106. Mudstone, porcelaneous; indurated. Phosphatic pellets, average 40 percent

105. Bentonite

104. Porcellanite; indurated. Phosphatic pellets, probably average 5 percent

103. Siltstone, olive-gray; weakly indurated

$\begin{array}{llll}0 & 2 & 0 & 5\end{array}$

102. Porcellanite and porcelaneous mudstone, indurated

$\begin{array}{llll}1 & 4 & 0 & 41\end{array}$

$\begin{array}{llll}0 & .5 & 0 & 1.2\end{array}$

$\begin{array}{llll}2 & 0 & 0 & 61\end{array}$

$\begin{array}{llll}0 & 4 & 0 & 41\end{array}$

$\begin{array}{llll}1 & 0 & 0 & 30\end{array}$

101. Siltstone, siliceous, or tuff; weakly indurated in upper 1 in. $(3 \mathrm{~cm})$. Phosphatic at base

$\begin{array}{llll}0 & 7 & 0 & 18\end{array}$

100. Bentonite, bentonitic siltstone, and siltstone

$\begin{array}{llll}1 & 8 & 0 & 51\end{array}$

99. Siltstone, siliceous. Some phosphatic pellets, some may be bentonitic

98. Bentonite

97. Claystone; bentonitic(?). Phosphatic pellets, 30 percent

96. Sandstone; $\tan$ to yellowishbrown, friable. Phosphatic pellets, 40 percent

$\begin{array}{llll}2 & 0 & 0 & 61\end{array}$

95. Porcellanite, chalky; indurated to very friable; weathers white. Probable bentonite bed, thin at base. Thickness uncertain. This unit and five underlying units make up correlation unit S2

94. Porcellanite; indurated

93. Bentonite

92. Porcellanite; indurated

91. Bentonite

90. Porcellanite; indurated

89. Mudstone, sandy at base. Phosphatic pellets, 40 percent

88. Bentonite

87. Porcellanite

86. Porcellanite. Phosphatic pellets, 10 percent

$\begin{array}{llll}2 & 0 & 0 & 61\end{array}$

$\begin{array}{llll}0 & .6 & 0 & 1.5\end{array}$

$\begin{array}{llll}0 & 4 & 0 & 10\end{array}$

85. Phosphorite, muddy, moderately indurated. Phosphatic pellets, 60 percent

84. Mudstone, porcelaneous. Phosphatic pellets, 10 percent

$\begin{array}{llll}0 & 7 & 0 & 18\end{array}$

83. Bentonite and bentonitic siltstone phosphatic; highly fractured. Phosphatic pellets 20 percent in upper half; 40 percent in lower half

82. Porcellanite; phosphatic pellets, 10 percent '

$\begin{array}{llll}1 & 8 & 0 & 51\end{array}$

$\begin{array}{llll}0 & 10 & 0 & 25\end{array}$ $\begin{array}{llll}1 & 0 & 0 & 30\end{array}$

$\begin{array}{llll}0 & 1 & 0 & 3\end{array}$

$\begin{array}{llll}0 & 1 & 0 & 3\end{array}$

$\begin{array}{llll}0 & 4 & 0 & 10\end{array}$

$\begin{array}{llll}0 & .6 & 0 & 1.5\end{array}$

$\begin{array}{llll}0 & 5 & 0 & 13\end{array}$

$\begin{array}{llll}1 & 5 & 0 & 43\end{array}$

$\begin{array}{llll}0 & .2 & 0 & .6\end{array}$

I 4041

$\begin{array}{llll}0 & 4 & 0 & 10\end{array}$

$\begin{array}{llll}1 & 0 & 0 & 30\end{array}$

$\begin{array}{llll}0 & 8 & 0 & 20\end{array}$

81. Phosphorite; phosphatic pellets 
Upper Miocene-Continued

Santa Margarita Formation-Continued

Upper phosphatic mudstone member-Continued Unit No.

$$
\text { Ft In } \quad \text { Thickness }
$$

80 percent. Base, sharp but very irregular; amplitude of grooves is 3 in. $(8 \mathrm{~cm})$. Sample CB-1 from unit. Correlation unit P3

80. Porcellanite; phosphatic pellets, 10 percent

79. Bentonite

78. Mudstone, siliceous; phosphatic pellets, 5 percent

77. Bentonite(?)

76. Mudstone, siliceous; phosphatic pellets, 10 percent

75. Phosphorite, muddy, phosphatic pellets, 70 percent

74. Porcellanite

73. Bentonite

72. Mudstone, siliceous; phosphatic pellets, 5 percent

71. Bentonite

70. Porcellanite, indurated

69. Mudstone, siliceous; phosphatic pellets, 20 percent

68. Bentonite and very phosphatic mudstone. Phosphatic pellets, average about 50 percent

67. Porcellanite. Phosphatic pellets, 30 percent in lower 4 in. (10 $\mathrm{cm}$ ) of unit; 5 percent in remainder

66. Phosphorite; phosphatic pellets, average 65 percent

65. Bentonite

64. Porcellanite, indurated

63. Bentonite; contains porcellanite fragments. Unit top and base sharp

$\begin{array}{llll}0 & 10 & 0 & 25\end{array}$

$\begin{array}{llll}0 & .6 & 0 & 1.5\end{array}$

$\begin{array}{llll}1 & 6 & 0 & 46\end{array}$ trace

$\begin{array}{llll}0 & 7 & 0 & 18\end{array}$

$\begin{array}{llll}0 & 2 & 0 & 5\end{array}$

$\begin{array}{llll}0 & .2 & 0 & .6\end{array}$

$\begin{array}{llll}3 & 1 & 0 & 94\end{array}$

$\begin{array}{llll}0 & .6 & 0 & 1.5\end{array}$

$\begin{array}{llll}1 & 1 & 0 & 33\end{array}$

$\begin{array}{llll}0 & 6 & 0 & 15\end{array}$

$\begin{array}{llll}1 & 0 & 0 & 30\end{array}$

$\begin{array}{llll}1 & 2 & 0 & 36\end{array}$

$\begin{array}{llll}1 & 1 & 0 & 33\end{array}$

$\begin{array}{llll}1 & 10 & 0 & 56\end{array}$

62. Porcellanite. This unit and two underlying units make up correlation unit $\mathrm{S} 3$

61. Bentonite

60. Porcellanite

59. Bentonite

58. Porcellanite; phosphatic pellets, 5 percent

57. Phosphorite, muddy, por-

- celaneous. Phosphatic pellets, 80 percent pellets. Unit top, gradational

56. Porcellanite; indurated. Phosphatic pellets, 20 percent

55. Bentónite

54. Porcellanite, indurated

53. Bentonite; contains broken fragments of porcellanite and bentonite

52. Porcellanite, indurated

51. Bentonite

50. Mudstone. Phosphatic pellets, about $\mathbf{4 0}$ percent. Unit base, very sharp, irregular; contains load casts

$\begin{array}{llll}1 & 1 & 0 & 33\end{array}$ $\begin{array}{llll}0 & 1 & 0 & 3\end{array}$

Upper Miocene--Continued

Santa Margarita Formation-Continued

Upper phosphatic mudstone member-Continued Unit No.

Thickness

Ft In $M \quad \mathrm{Cm}$

49. Porcellanite; slightly phosphatic

48. Bentonite

47. Porcellanite

46. Bentonite

45. Siltstone, siliceous. Phosphatic nodules and pellets, about 5 percent

44. Bentonite and siliceous siltstone broken zone

43. Porcellanite, indurated. Trace of bentonite 10 in. $(25 \mathrm{~cm})$ above base

42. Mudstone, siliceous. Phosphatic pellets, 20 percent in upper 7 in. $(18 \mathrm{~cm}) ; 40$ percent in lower unit

41. Bentonite

40. Siltstone, siliceous. Phosphatic pellets, 5 percent

39. Bentonite

38. Siltstone, siliceous; indurated. Phosphatic pellets, 5 percent

37. Phosphorite, sandy, yellowishbrown; friable to semifriable. Phosphatic pellets, 80 percent

36. Siltstone; some phosphate; olivegray. This unit and underlying unit make up correlation unit S4

160046

$\begin{array}{llll}0 & 1 & 0 & 3\end{array}$

$\begin{array}{llll}0 & 7 & 0 & 18\end{array}$ trace

$\begin{array}{llll}0 & 8 & 0 & 20\end{array}$

$\begin{array}{llll}1 & 0 & 0 & 30\end{array}$

$\begin{array}{llll}0 & 4 & 0 & 10\end{array}$

35. Sandstone, phosphatic, brownishgray, very fine grained. Weathered. Poorly exposed

34. Siltstone, bentonitic, light-yellowish-gray. Weathers white and chalky

33. Sandstone; grades upward to siltstone, yellowish-gray to yellowish-brown; weathered white at top. Friable in lower 7 in. $(18 \mathrm{~cm})$ to moderately indurated upward. Phosphatic pellets, about 25 percent

Total measured thickness of upper phosphatic mudstone member in Eastern Trench:

Section continues in Western Trench. Good correlation between trenches

\section{Western Trench}

$\begin{array}{llll}0 & 7 & 0 & 18\end{array}$

$\begin{array}{llll}0 & .6 & 0 & 1.5\end{array}$

Upper Miocene:

Santa Margarita Formation

Upper phosphatic mudstone member:

32. Sandstone, very fine grained, and sandy siltstone, light-gray. Phosphatic pellets, 30 percent. Upper $1 \mathrm{ft}(30 \mathrm{~cm})$ of unit, very fine siltstone or claystone; contains phosphatic pellets, 5 percent. Correlation unit P4 
Upper Miocene-Continued

Santa Margarita Formation-Continued

Upper phosphatic mudstone member-Continued

Unit No.

31. Siltstone, siliceous; some greenish-yellow stains. Some megafossils

30. Siltstone, somewhat bentonitic, olive-gray

29. Siltstone, sandy; slightly phosphatic

28. Sandstone, very fine grained, and siltstone, locally yellowish; friable in lower part of unit. Phosphatic pellets, 10 percent. Megafossils, abundant

27. Siltstone, siliceous, light-gray

26. Porcellanite, indurated

25. Phosphorite, muddy, silty, phosphatic pellets, 75 percent

24. Siltstone, siliceous

23. Bentonite, and some bentonitic siltstone

22. Porcellanite, indurated

21. Sandstone, very fine grained, or siltstone. Phosphatic pellets, 5 percent

20. Sandstone, very fine grained, and siltstone, light-gray, friable to moderately indurated

19. Sandstone, very fine grained, yellowish-orange-brown, very friable

18. Siltstone, tuffaceous(?), light-gray

17. Bentonite and bentonitic siltstone

16. Porcellanite, siliceous, indurated. Massive at top

15. Siltstone, siliceous

14. Siltstone; phosphatic pellets, 10 percent

13. Siltstone; partly slightly phosphatic; light-gray

12. Sandstone, very fine grained, friable. Phosphatic pellets, 50 percent in lower part

$\begin{array}{llll}5 & 6 & 1 & 68\end{array}$

$\begin{array}{llll}2 & 8 & 0 & 81\end{array}$

$\begin{array}{llll}2 & 0 & 0 & 61\end{array}$

।

$\begin{array}{llll}2 & 0 & 0 & 61\end{array}$

$\begin{array}{llll}4 & 6 & 1 & 37\end{array}$

$\begin{array}{llll}2 & 0 & 0 & 61\end{array}$

$\begin{array}{llll}0 & 6 & 0 & 15\end{array}$

$\begin{array}{llll}0 & 10 & 0 & 25\end{array}$

$\begin{array}{llll}1 & 6 & 0 & 46\end{array}$

$\begin{array}{llll}2 & 1 & 0 & 64\end{array}$

$\begin{array}{llll}2 & 0 & 0 & 61\end{array}$

$\begin{array}{llll}5 & 0 & 1 & 52\end{array}$

$\begin{array}{llll}0 & 8 & 0 & 20\end{array}$

$\begin{array}{llll}2 & 6 & 0 & 76\end{array}$

16046

$\begin{array}{llll}3 & 0 & 0 & 91\end{array}$

$\begin{array}{llll}0 & 8 & 0 & 20\end{array}$

$\begin{array}{llll}0 & 7 & 0 & 18\end{array}$

$\begin{array}{llll}2 & 4 & 0 & 71\end{array}$

$\begin{array}{llll}3 & 5 & 1 & 4\end{array}$

11. Sandstone, very fine grained, silty, light-gray. Phosphatic pellets, about 1 percent. Texture sugary

10. Siltstone, tuffaceous(?), lightgray, massive, indurated; texture sugary. Finer grained at base

9. Siltstone, siliceous, with some bentonitic siltstone

8. Siltstone, siliceous

7. Bentonite

6. Siltstone and very fine grained sandstone

5. Sandstone, reddish-brown to yellow, very friable. Phosphatic pellets and nodules, about 10 percent. Mollusks, locally abundant

$$
\begin{array}{llll}
\multicolumn{4}{c}{\text { Thickness }} \\
\text { Ft } & \text { In } & M & C m
\end{array}
$$

Upper Miocene-Continued

Santa Margarita Formation-Continued

Upper phosphatic mudstone member-Continued Unit No. Thickness

$$
\text { Ft In } \quad \mathrm{M} \quad \mathrm{Cm}
$$

Total measured thickness of the upper phosphatic mudstone member in Western Trench:

$\overline{64} \overline{0} \overline{19} \overline{49}$

Total thickness of the upper phosphatic mudstone member (Eastern and Western trenches): $\overline{174} \overline{7} \overline{53} \overline{18}$

Upper Miocene

Santa Margarita Formation:

Lower sandstone member:

4. Sandstone, very fine grained, and siltstone, feldspathic, lightgray. Thickness approximate

3. Sandstone, light-brown, very fine grained. Phosphatic pellets, 10 percent. Small fossils and some phosphatized shells, abundant. Strata, broken up

2. Sandstone, light-gray, very fine grained, feldspathic. Unit coated white

$\begin{array}{llll}8 & 2 & 2 & 49\end{array}$

1. Sandstone, very fine grained; weathered. Weathering yields abundant hard sandstone fragments

$2+-061+$

Total measured thickness of lower sandstone member:

$\frac{-}{20} \overline{2} \overline{6} \overline{15}$

\section{TRENCH 300}

(Measured by H. D. Gower, 1964; E and F numbered samples described petrographically by $\mathrm{T}$. L. Vercoutere)

LOCATION: SW1/4SE1/4 sec. 7, T. 9 N., R. 26 W. (S.S.B. \& M.) in the Salisbury Potrero, California quadrangle

ATTITUDE OF BEDDING: N. $54^{\circ} \mathrm{W} .79^{\circ} \mathrm{N}$. (good) in middle of trench TREND OF TRENCH: Approximately N. $50^{\circ} \mathrm{E}$.

Upper Miocene:

Santa Margarita Formation:

Upper sandstone member: Unit No.

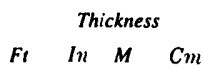

78. Sandstone, yellowish-gray $(5 Y 7 / 2)$ to light-olive-gray (5Y6/1), very fine grained, friable. Phosphatic pellets, dark-yellowish-brown (10YR4/2), fine- to coarsegrained, 1 to 3 percent

$\begin{array}{llll}5 & 4 & 1 & 63\end{array}$

77. Sandstone, yellowish-gray, finegrained; friable. Phosphatic pellets, dark-yellowish-brown (10YR4/2), about 1 percent

76. Sandstone, white, fine- to medium-grained; friable. Probably high feldspar content; weathered to koalinite

Total measured thickness of the upper sandstone member 
Upper Miocene:

Santa Margarita Formation:

Upper phosphatic mudstone member: Unit No.

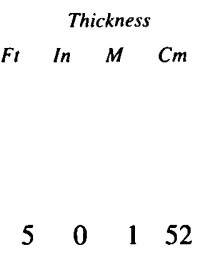

75. Siltstone, probably bentonitic, pale-olive (10Y6/2), highly sheared. Some phosphatic pellets, grayish-orange (10YR 7/4), fine-grained

74. Siltstone, yellowish-gray $(5 Y 7 / 2)$ Phosphatic pellets, fine- to medium-grained, 5 percent. Base of unit, dark-reddishbrown; paler upwards. Echinoid spines, as large as $1 / 4$ in. $(6 \mathrm{~mm})$, abundant near base

73. Siltstone, probably bentonitic, slightly phosphatic, light-olivegray $(5 \mathrm{Y} 6 / 1)$; sheared

72. Siltstone, yellowish-gray $(5 Y 7 / 2)$. Phosphatic pellets, dark-reddish-brown (10R3/4), fine- to medium-grained, about 3 percent. Nodules, less than $1 / 4$ in. $(6 \mathrm{~mm})$ long, abundant. Unit in fault contact with underlying unit

$\begin{array}{llll}1 & 8 & 0 & 51\end{array}$

Section missing

71. Siltstone, slightly siliceous, grayish-yellow (5Y8/4); patches of white caliche coatings. Quartz grains, very coarse, about 1 percent. Phosphatic pellets, fine- to mediumgrained, 1 percent. Few nodules. Small pebbles scattered in this and underlying two units

70. Siltstone, yellowish gray $(5 Y 7 / 2)$; highly sheared. Phosphatic pellets, dark-reddish-brown, fineto medium-grained, 3 percent. Nodules as large as $1 / 4$ in. (6' $\mathrm{mm}$ ) common

69. Siltstone, slightly siliceous, yellowish-gray to grayish-yellow; indurated; sheared. Phosphatic pellets, red-brown, very hard, rare, some caliche coated

68. Siltstone, yellowish-gray to dusky-yellow (5Y6/4), sandy, phosphatic. Pellets, lightbrown at top; reddish-brown at base

$\begin{array}{llll}2 & 2 & 0 & 66\end{array}$

$\begin{array}{llll}2 & 2 & 0 & 66\end{array}$

67. Siltstone, siliceous; sheared. Phosphatic pellets, light to dark, 3 percent

66. Sandstone, very fine grained, or siltstone; sheared. Phosphatic pellets, dark-red-brown, fineto medium-grained; 50 percent in lower 7 in. $(18 \mathrm{~cm})$ of unit, 15 percent in remainder

65. Siltstone, slightly siliceous, yellowish-gray to dusky-yellow; may be bentonitic at top of unit. Phosphatic pellets, 2 percent in upper two-thirds of $\begin{array}{llll}3 & 0 & 0 & 91\end{array}$

$\begin{array}{lllll}2 & 0 & 0 & 61\end{array}$

Upper Miocene-Continued

Santa Margarita Formation-Continued

Upper phosphatic mudstone member-Continued Unit No.

$$
\text { Fi In } \quad M \quad C m
$$

unit; phosphatic pellets with some phosphatic disks (probably diatoms or Foraminifera), 20 percent in lower one-third

64. Mudstone, phosphatic, pelletal, silty; siliceous matrix. Grains, subangular to subrounded, poorly sorted, randomly oriented grains. Framework, 12 percent quartz, 3 percent feldspar, and 37 percent phosphate; matrix, 47 percent clay minerals; accessory minerals, 1 percent, include zircon, muscovite, chlorite, and magnetite. Phosphatic framework, 14 percent pellets with noncentered inclusions and 43 percent pellets with centered inclusions of quartz feldspar and diatom frustules, 22 percent structureless pellets, 8 percent fishbone fragments, 5 percent shell fragments, 5 percent compound pellets, and 3 percent phosphatic nodules. Pellets, spheroids, regular to slightly irregular; range from 0.06 to $0.35 \mathrm{~mm}$ in diameter; average diameter $0.12 \mathrm{~mm}$; boundaries, sharp to fuzzy; hematite rims common. Pellet-supported areas, deformed pellets common, and hematite staining abundant; pellet-free areas, staining absent. Siltstone, bentonitic, phosphatic, 3 in. (8 $\mathrm{cm}$ ) bed in center of unit. Sample F1208-15 from unit. Phosphatic pellet with centered inclusions (pl. $6 G$ ), fish vertebrae (pl. $6 E$ ), compound phosphatic pellet (pl. $6 I$ ), and structureless phosphatic pellet (pl. $6 F$ )

63. Siltstone, slightly siliceous, olivebrown; sheared. Phosphatic pellets, about 2 percent. Siltstone, bentonitic, 2 in. zone 5 in. $(13 \mathrm{~cm})$ above base
62. Phosphorite. Grains, silt-sized, subrounded, medium-sorted, randomly oriented; floating grains, as large as medium size, rare. Framework, 5 percent quartz, 4 percent feldspar, 69 percent phosphate; matrix, 12 percent siliceous clay minerals, and 11 percent iron oxide. Phosphatic framework, 26 percent pellets with noncentered pellets and 19 percent pellets with centered inclusions of 
Upper Miocene-Continued

Santa Margarita Formation-Continued

Upper phosphatic mudstone member-Continued Unit No.

quartz, feldspar, and diatom and shell-fragments, 46 percent structureless pellets, and 9 percent fossil fragments. Pellets, spheroids, regular to slightly irregular; range from 0.08 to $0.85 \mathrm{~mm}$ in diameter; bimodal distribution, average $0.15 \mathrm{~mm}$ and $0.50 \mathrm{~mm}$ in diameter; boundaries, sharp; protruding grains rare; compressional flattening slight along contacts. Stain, iron oxide; hematite, substantial amount in most areas, much concentrated along pellet rims. $\mathrm{X}$-ray diffraction analysis indicates presence of opal-CT.

Base of unit, very irregular; amplitude of 3 in. $(8 \mathrm{~cm})$; some burrows. Correlation unit PI. Samples F1208-16 and PI-300 from unit

61. Siltstone, siliceous, olive-gray. Phosphatic pellets, lightgrayish-orange to dark-brown, very fine- to coarse-grained, 3 percent. Bentonitic bed, thin, 5 in. $(13 \mathrm{~cm})$ above base

60. Siltstone, light-olive-gray; breaks into very fine fragments. Phosphatic pellets, very abundant locally at top. Bentonitic siltstone in middle of unit

59. Siltstone, sandy, siliceous, slightly calcareous, whitestained; hard. Phosphatic pellets, average 4 percent concentrated around abundant fish fragments. Basal $I$ in. (3 $\mathrm{cm}$ ) of unit, partly friable sandstone with abundant phosphatic nodules and 20 percent phosphatic pellets

58. Siltstone, bentonitic; very bentonitic in upper third of unit. Phosphatic pellets, 5 percent in lower two-thirds of unit. Sheared

57. Siltstone, slightly calcareous, some phosphate; white-stained; indurated. Contains megafossils

56. Siltstone. Phosphatic pellets, grayish-orange, fine- to coarsegrained, about 1 percent. Foraminiferal and megafossil molds locally abundant in upper $1 \mathrm{ft}(30 \mathrm{~cm})$. Siltstone, very bentonitic, 4 in. $(10 \mathrm{~cm})$ bed $1 \mathrm{ft}(30 \mathrm{~cm})$ below top of unit
Upper Miocene-Continued

Santa Margarita Formation-Continued

Upper phosphatic mudstone member-Continued

Unit No.

Thickness

Ft In $M \quad C m$

ately hard to semifriable.

Nodules and phosphatic pel-

lets, brown, fine- to coarse-

grained, 40 percent. Upper 2

in. $(5 \mathrm{~cm})$ of unit, silty; phosphatic pellets, 30 percent.

Correlation unit $\mathrm{P} 2$

$\begin{array}{llll}0 & 11 & 0 & 38\end{array}$

54. Siltstone, siliceous, slightly calcareous; indurated; sheared.

Phosphatic pellets, light-

brown; 2 percent in upper half,

10 percent in lower half. Unit coated with caliche. Correlation unit SI

$\begin{array}{llll}1 & 4 & 0 & 41\end{array}$

53. Sandstone, tan; friable; cut by calcite veinlets. Phosphatic pellets, very pale orange to paleyellowish-brown, fine- to coarse-grained, many diskshaped and ellipsoidal, 40 percent. Basal contact, sharp

52. Limestone, indurated; speckled with silt-size quartz. Unit coated with caliche

$\begin{array}{llll}0 & 8 & 0 & 20\end{array}$

51. Siltstone, olive-gray, bentonitic in part; sheared

$\begin{array}{llll}2 & 4 & 0 & 66\end{array}$

50. Bentonite

49. Siltstone, olive-gray; some bentonite and hard porcellanite. Phosphatic pellets, distinctly pinkish, very fine grained

48. Porcellanite, indurated, and siliceous claystone; slightly bentonitic

47. Siltstone, and bentonitic siltstone, olive-gray; moderately indurated. Phosphatic pellets, pinkish, very fine grained

46. Mudstone, phosphatic, pelletal, silty; laminations, faintly wavy. Grains, subangular to subrounded, poorly sorted, oriented subparallel to laminae; floating grains to medium size. Framework, 8 percent quartz, 4 percent feldspar, 24 percent phosphate; matrix, 62 percent clay minerals, and 2 percent iron oxide. Phosphatic framework, 53 percent pellets with noncentered inclusions of quartz, feldspar, hematite, chlorite, and diatom fragments, 32 percent structureless pellets, and 15 percent compound pellets. Pellets, spheroids, regular to slightly irregular; range from $0.13 \mathrm{~mm}$ to $0.75 \mathrm{~mm}$ in diameter; average diameter $0.30 \mathrm{~mm}$; boundaries, sharp to fuzzy; rims of hematite rare and secondary phosphate common; peripheral deformation slight; 
Upper Miocene-Continued

Santa Margarita Formation-Continued

Upper phosphatic mudstone member-Continued Unit No.

Thickness

$\mathrm{Ft}$ In $\mathrm{M} \quad \mathrm{Cm}$

concentrated in pellet-sup-

ported lenses. Sample

F1208-29 from unit

45. Siltstone and bentonitic siltstone, olive-gray

$\begin{array}{llll}3 & 7 & 1 & 9\end{array}$

$\begin{array}{llll}0 & 4 & 0 & 10\end{array}$

44. Siltstone, siliceous, sandy, light-

gray when fresh; massive, indurated. Phosphatic pellets, 10 percent

43. Siltstone, and bentonitic siltstone, olive-gray. Phosphatic pellets, scattered. Bentonite, 2 in. bed

42. Siltstone, siliceous, olive-gray; indurated; caliche-coated

41. Bentonite

40. Siltstone, olive-gray

39. Sandstone, fine-grained. Phosphatic pellets, 35 percent. Gradational basal contact

38. Sandstone, fine-grained. Phosphatic pellets, light-gray to light-brown, fine- to mediumgrained, 45 percent. Quartz, coarse-grained, especially in lower part of unit. Base, sharp

37. Siltstone, siliceous, may be slightly calcareous; whitestained; indurated

36. Siltstone, siliceous, may be slightly calcareous; whitestained; indurated. Correlation unit $\mathrm{S} 2$

$\begin{array}{llll}0 & 11 & 0 & 28\end{array}$ $1.1 \mathrm{ft}(33 \mathrm{~cm})$ below top of unit

Upper Miocene-Continued

Santa Margarita Formation-Continued

Upper phosphatic mudstone member-Continued Unit No.

grains, rare; slight compressional flattening; nuclei rarely incipiently calcitized; locally pellet supported; oolitic structured pellets, very rare. Pebble fragments contain grains of silt-size material and pellets, very rare. Sample E1205-14 from unit

34. Siltstone, siliceous

33. Siltstone, bentonitic, and siltstone, olive-gray; moderately indurated

32. Siltstone, siliceous

31. Porcellanite: Phosphatic pellets, 15 percent

30. Mudstone, very phosphatic, pelletal. Grains, angular to subrounded, poorly sorted, oriented subparallel to thickly laminated alternating pelletrich and grain-mud-rich sediments; floating grains, very coarse, rare. Framework, 10 percent quartz, 5 percent feldspar, 46 percent phosphate; matrix, 36 percent clay minerals, and 2 percent iron oxide; accessory minerals, 1 percent, include zircon, chlorite, magnetite, and hematite.

Phosphatic framework, 33 percent pellets with noncentered inclusions and 28 percent pellets with centered inclusions of quartz, feldspar, diatom fragments, and very rare zircon, 28 percent structureless pellets, 8 percent compound pellets, 1 percent nodules without inclusions, and 2 percent shell fragments as large as $1 \mathrm{~mm}$. Pellets, spheroidal, regular to slightly irregular; approximately $0.15 \mathrm{~mm}$ in diameter; boundaries, sharp, very abundant; rims commonly secondary phosphate; intruding grains rare; in pellet-supported zones, very much slight compressional flattening; nuclei, incipiently calcitized; some poorly developed oolitic structure, rare. Sample E1205-15 from unit

29. Siltstone, sandy. Phosphatic pellets, 15 percent. Quartz grains, coarse pebble fragments, 10 percent shell fragments as large as 4 $\mathrm{mm}$. Pellets, spheroidal; range from $0.09 \mathrm{~mm}$ to $0.30 \mathrm{~mm}$ in diameter; boundaries, sharp; rims rarely calcareous or secondary phosphate; protruding 
Upper Miocene-Continued

Santa Margarita Formation-Continued

Upper phosphatic mudstone member-Continued

Unit No.

27. Siltstone, siliceous. Phosphatic pellets, average 15 percent

26. Phosphorite, tan to brown. Phosphatic pellets, 75 percent. Base, very irregular, burrowed. Correlation unit P3

Fi $\quad$ In $\quad M \quad C m$

$\begin{array}{llll}0 & 5 & 0 & 13\end{array}$

Siltstone, siliceous; massive indurated. Phosphatic pellets, 20 percent. Concretion, paleorange, small, one, at top of unit

24. Siltstone, siliceous; massive indurated. Phosphatic pellets, about 50 percent in unit; 30 percent in upper 5 in. $(13 \mathrm{~cm})$. Quartz grains, very coarse, locally abundant

23. Siltstone, moderately indurated. Phosphatic pellets, about 30 percent

22. Sandstone, very fine grained, or siltstone; massive, indurated. Phosphatic pellets, light-gray, 25 percent. Quartz grains, very coarse, locally abundant, Base, very irregular

21. Siltstone, siliceous, slightly phosphatic, indurated. Mudstone, friable, 4 in. $(10 \mathrm{~cm})$ bed 6 in. $(15 \mathrm{~cm})$ below top; contains phosphatic pellets, 10 percent

20. Mudstone, siliceous, phosphatic. Upper 7 in. $(18 \mathrm{~cm})$ of unit, indurated; contains phosphatic pellets, more distinct than those lower, 20 percent; indistinct, 40 percent in lower $1 \mathrm{ft}$ $(30 \mathrm{~cm})$

19. Mudstone, very phosphatic, pelletal, silty; siliceous matrix. Grains, angular to subrounded, poorly sorted, randomly oriented; floating grains, as large as coarse size, rare. Framework, 11 percent quartz, 8 percent feldspar, 41 percent phosphate, matrix, 38 percent clay minerals; accessory minerals, 2 percent, include zircon, hematite, magnetite, chlorite, and muscovite. Phosphatic framework, 34 percent pellets with noncentered inclusions and 24 percent pellets with centered inclusions of quartz, feldspar, hematite, zircon, and diatom fragments, and 37 percent structureless pellets, and 5 percent nodules and fossil fragments. Pellets, spheriods, regular to slightly irregular; range from $0.08 \mathrm{~mm}$ to 0.35 $\mathrm{mm}$ in diameter; average diam-
Upper Miocene-Continued

Santa Margarita Formation-Continued

Upper phosphatic mudstone member-Continued Unit No.

Thickness

eter $0.18 \mathrm{~mm}$; boundaries, sharp to slightly fuzzy; rims commonly secondary phosphate and commonly calcareous; slight compressional flattening common; compound pellets rare. Framework grains and pellet nuclei rarely incipiently calcitized. Shell fragment, phosphatized, as large as $2 \mathrm{~mm}$, rare. Base, sharp, irregular. Sample F1208-13 from unit

18. Siltstone, porcelaneous. Phosphatic pellets, 5 percent

17. Claystone, siliceous, slightly phosphatic; laminations wavy. Clay matrix contains anastomosing veins of iron oxide and illite. Grains, subangular to subrounded, medium-sorted, randomly oriented; floating grains, as large as very coarse size. Framework, 5 percent quartz, 1 percent feldspar, 3 percent phosphate; matrix, 89 percent clay minerals; accessory minerals, 1 percent, include hematite, zircon, sphene(?), magnetite, chlorite(?). Phosphatic framework, 33 percent pellets with inclusions of quartz and diatom fragments, 64 percent structureless pellets, and 3 percent phosphatized shell fragments. Pellets, spheroids, regular to slightly irregular; range from $0.10 \mathrm{~mm}$ to $0.30 \mathrm{~mm}$ in diameter; boundaries predominantly fuzzy; rims illite(?)-coated, very rare. Sample F1208-8 from unit

16. Bentonite and bentonitic siltstone

15. Claystone, silty, siliceous, slightly phosphatic; laminated, faint, wavey. Grains, subangular to subrounded, poorly sorted, randomly oriented; floating grains as large as coarse size. Framework, 13 percent quartz, 6 percent feldspar, 3 percent phosphate; matrix, 77 percent clay minerals; accessory minerals, 1 percent, include zircon, biotite, hematite, chlorite, muscovite, magnetite, glauconite, and sphene. Phosphatic framework, pellets with inclusions of quartz, feldspar (rare), diatom fragments, and phosphatized shell fragments as much as 2 $\mathrm{mm}$ long, and structureless pel- 
Upper Miocene-Continued

Santa Margarita Formation-Continued

Upper phosphatic mudstone member-Continued Unit No.

$$
\text { Ft In M Cm }
$$

lets. Pellets, spheroids; average diameter $0.10 \mathrm{~mm}$; boundaries, sharpness variable, mostly fuzzy; minor secondary calcitization of grains. X-ray diffraction analysis indicates major clay mineral, montmorillonite; minor minerals, illite, and opal-CT. Correlation unit S3. Sample F1208-9 from unit

14. Mudstone, phosphatic, silty, siliceous; laminae, alternating pellet rich and pellet poor. Pellet-rich laminae, pellet supported; pellet-poor laminae, wavey fine laminae of alternating illite-rich mud and montmorillonite-iron oxiderich mud. Grains, angular to subrounded, poorly sorted, randomly oriented. Framework, 14 percent quartz, 6 percent feldspar, 35 percent phosphate; matrix, 42 percent clay minerals, 2 percent iron oxide; accessory minerals, 1 percent. Phosphatic framework, 26 percent pellets with noncentered inclusions and 11 percent pellets with centered inclusions of quartz, feldspar, and diatom fragments (some nearly whole), 43 percent structureless pellets, 16 percent compound pellets, 3 percent shell fragments, and 1 percent nodules (including pellet grapestone). Pellets, spheroids; range from $0.6 \mathrm{~mm}$ to 0.50 $\mathrm{mm}$ in diameter; average diameter $0.18 \mathrm{~mm}$; boundary sharpness variable, pellets that have been secondarily phosphatized commonly have slightly fuzzy boundaries. Diagenetic alterations; framework grains commonly incipiently calcitized and pellet nuclei rarely. Phosphatic pellets and nodules stained with hematite. Sample F1208-10 near base. Compressed compound pellets (pl. $6 K$ ), pellet with ferruginous bands (fig. 10), and grapestone intraclast (pl. $6 M$ ) from unit

13. Siltstone, siliceous. Phosphatic pellets, 10 percent. Bentonitic(?) zone, 4 in. $(10 \mathrm{~cm})$, weakly indurated, at base

12. Claystone, moderately phos-
Upper Miocene-Continued

Santa Margarita Formation-Continued

Upper phosphatic mudstone member-Continued Unir No.

Thickness Ft In $M \quad \mathrm{Cm}$

phatic, slightly silty, siliceous. Hematite-rich muds faintly banded, approximately $1 \mathrm{~mm}$ wide, not laterally continuous as individual lamina but fairly continous as a zone. Grains, angular to rounded, poorly sorted; oriented subparallel to crude wavey laminae; floating grains, as large as coarse size, very rare. Framework, 7 percent quartz, 3 percent feldspar, 10 percent phosphate; matrix, 79 percent clay minerals; accessory minerals, 1 percent, inçlude muscovite, hematite, zircon, and magnetite. Phosphatic framework, 30 percent pellets with noncentered grain inclusions and 20 percent pellets with centered inclusions, 50 percent structureless pellets, and 1 percent shell fragments and diatom fragments, very rare. Grain inclusions, quartz predominates, lesser amounts of feldspar, hematite (rare), and diatom fragments (rare). Pellets, spheroids; range from $0.06 \mathrm{~mm}$ to $50 \mathrm{~mm}$ in diameter; average diameter $0.14 \mathrm{~mm}$; boundaries, range from sharp to fuzzy. Pellets with secondary phosphate rims, between 0.01 $\mathrm{mm}$ and $0.03 \mathrm{~mm}$ thick, common, especially in hematiterich laminae. Incipient pellets (rare) have smaller diameter than other pellets. Incipient secondary calcification of framework grains rare. Sample F1208-11 near top; F1208-12 near base

11. Sandstone, light-brown, very fine grained. Phosphatic pellets, 25 percent

10. Porcellanite; massive; indurated. Phosphatic pellets, 5 percent. Base, faulted. Attitude of fault, N. $60^{\circ}$ E. $72^{\circ} \mathrm{N}$. (good) Section missing

$\begin{array}{llll}2 & 0 & 0 & 61\end{array}$

$\begin{array}{llll}15 & 0 & 4 & 58\end{array}$

9. Phosphorite; phosphatic siltstone in upper half of unit. Phosphatic pellets, 30 percent in upper half and 60 percent in lower half. Large bone, mammal(?), at base similar to bones in trench 297 , stratigraphic unit 35

8. Siltstone, siliceous, indurated. Phosphatic pellets, 5 percent

7. Wackestone, phosphatic, 
Upper Miocene-Continued

Santa Margarita Formation-Continued

Upper phosphatic mudstone member-Continued

Unil No.

Thickness

Fi In $M \quad C m$

medium-sorted, matrix sup-

ported, carbonate cement.

Grains, subangular, randomly

oriented. Framework, 6 percent

quartz, 3 percent feldspar, 32

percent phosphate; matrix, 55

percent carbonate, and 2 per-

cent iron oxide. Some frame-

work grains secondary cal-

citization. Phosphatic frame-

work, 60 percent pellets with

inclusions of quartz, feldspar,

hematite, zircon and diatom

fragments and iron oxide

(rare); remainder are struc-

tureless pellets. Pellets,

spheroids, regular to slightly

irregular; range from $0.10 \mathrm{~mm}$

to $0.30 \mathrm{~mm}$ in diameter; nuclei

commonly partially calcitized.

Pellets with very sharp bound-

aries commonly have

calcareous rims. Nodules,

phosphatic, less than $1 \mathrm{~mm}$

long, rare. Large burrows at

base and in underlying ben-

tonite and siltstone. Sample

FI208-14 from unit

6. Bentonite

$\begin{array}{llll}1 & 0 & 0 & 30\end{array}$

$\begin{array}{llll}0 & 2 & 0 & 5\end{array}$

5. Siltstone, olive-gray. Phosphatic pellets, 5 percent. Correlation unit $\$ 4$

4. Bentonite

3. Siltstone, and very fine grained siliceous sandstone; 2 percent phosphatic pellets in lowest 6 in. $(15 \mathrm{~cm})$

2. Sandstone, very fine grained and fine-grained. Phosphatic pellets, 10 percent in very fine grained sandstone and 15 percent pellets in fine-grained sandstone in basal 7 in. (18 $\mathrm{cm}$ ). Thickness, uncertain for this unit and underlying unit

1. Sandstone, fine-grained; sheared. Phosphatic pellets, 20 percent in upper 10 in. $(25 \mathrm{~cm})$ of unit and 60 percent in lower part. Correlation unit P4. Sample 300-P4 from unit

Total measured thickness of upper phosphatic mudstone member $\begin{array}{llll}2 & 0 & 0 & 61\end{array}$

$\begin{array}{llll}1 & 1 & 0 & 33\end{array}$

$\begin{array}{llll}0 & 1 & 0 & 3\end{array}$

$\begin{array}{llll}1 & 6 & 0 & 46\end{array}$

$130 \quad 11 \quad 39 \quad 90$

\section{TRENCH 400}

(Measured by H. D. Gower, 1971)

LOCATION: SE $1 / 4$ SE1/4 sec. 7, T. 9 N., R. 26 W. (S.S.B. \& M.) in the

Salisbury Potrero, California quadrangle.

ATTITUDE OF BEDDING: Approximately N. $80^{\circ} \mathrm{W}$. $65^{\circ} \mathrm{S}$. overturned TREND OF TRENCH: Approximately N. $15^{\circ} \mathrm{E}$.

Upper Miocene:

Santa Margarita Formation:

Upper phosphatic mudstone member: Unit No.

$$
\text { Ft in } \quad M \quad c m
$$

77. Sandstone, arkosic, kaolinitic(?) white, fine- to mediumgrained; semifriable. Quartz grains, few

$5+-152+$

76. Covered interval. Probably siltstone. Thickness approximate

75. Siltstone, siliceous, grayishbrown (5YR3/2) to pale-yellowish brown (10YR6/2), indurated. Locally, especially in middle of unit, made up mostly of phosphatic pellets

$\begin{array}{llll}3 & 0 & 0 & 91\end{array}$

74. Siltstone, siliceous to bentonitic; greenish-gray; indurated to friable, thin-bedded. Phosphatic pellets, smooth surfaces, irregular outlines, atypically washed, scattered. Several clam casts near top of unit

$\begin{array}{llll}1 & 8 & 0 & 51\end{array}$

73. Phosphorite, weathers brownishgray. Phosphatic pellets, lightgray; slightly polished, especially in lower part of unit; 15 percent at top and 60 percent pellets at base; apparent nodular aggregates at base. Base sheared

$\begin{array}{llll}0 & 10 & 0 & 25\end{array}$

72. Siltstone, siliceous, platy, greenish-gray; indurated; sheared. Phosphatic pellets, 5 to 10 percent. Surfaces, caliche encrusted, white

$\begin{array}{llll}0 & 6 & 0 & 15\end{array}$

71. Claystone, medium-brown; phosphatic pellets, locally abundant. Grades into underlying unit

70. Phosphorite, nodular, dark-brown. Nodules, as much as 1 in. (3 $\mathrm{cm}$ ) long; many nodules are aggregated pellets. pellets scattered

69. Claystone, slightly siliceous, greenish-gray to light-gray. Phosphatic(?) nodules, white, lenticular ( $1 / 4$ in. $x 3$ in.) (0.6 $\mathrm{cm} \times 7.6 \mathrm{~cm})$, rare. Middle unit, two zones, possibly bentonite. Top unit, very fissile

68. Siltstone, siliceous, light-gray, indurated

67. Bentonite

$\begin{array}{llll}0 & .6 & 0 & 1.5\end{array}$

66. Siltstone, siliceous, yellowishgray (5Y8/1); beds, $1 / 2$ in. to 4 in. $(1.3 \mathrm{~cm}$ to $10 \mathrm{~cm})$, indurated; interbeds, claystone, weakly indurated, relief is 4 or 5 in. $(10$ to $13 \mathrm{~cm})$ between claystone and siltstone. Apparently no phosphate. Some fishscale imprints on surfaces

65. Siltstone, platy, yellowish-gray Some phosphatic nodules, 
Upper Miocene-Continued

Santa Margarita Formation-Continued

Upper phosphatic mudstone member-Continued Unit No.

white, small. Bentonitic(?)

claystone two thin beds in lower 6 in. $(15 \mathrm{~cm})$

64. Phosphorite and moderately phosphatic siltstone, yellowish-gray to light-brown. Phosphatic pellets, 10 percent at top and 80 percent or more in lower part of unit; phosphatic pebbles or nodules as large as $1 / 2$ in. (1.3 $\mathrm{cm}$ ) largely make up basal third of unit. Base, faulted; partly burrowed by clams Section missing

63. Siltstone, siliceous; indurated

62. Claystone and siltstone, bentonitic, friable. Siltstone beds, siliceous, thin, indurated, few

61. Siltstone, siliceous; indurated

60. Tuff(?), light-orange to light-gray; sugary texture

59. Claystone, siliceous; very thin bedded; moderately indurated

58. Siltstone, siliceous, indurated. Abundant foraminifers

57. Bentonite, siliceous, indurated

56. Bentonite(?) and clayey mudstone

55. Phosphorite, silica cement, brownish-gray; indurated. Base irregular

54. Claystone, siliceous; weathers light-gray; moderately indurated, harder in lower part of unit. Upper part of unit, some thin clayey mudstone and silty bentonite(?) beds

53. Claystone, bentonitic

52. Siltstone, siliceous; indurated; brown-weathering. Some foraminiferal molds

51. Claystone; slightly bentonitic(?); weakly indurated

50. Phosphorite, light-gray. Phosphatic pellets, polished, as much as 80 percent. Base irregular. Correlation unit PI

49. Siltstone, siliceous; indurated. Phosphatic pellets, locally abundant

48. Bentonite and bentonitic claystone

47. Siltstone, phosphatic, siliceous grades downward to pebbly phosphorite in lower half of unit. Contains phosphatic nodules and pellets

$\begin{array}{lll}7 & 0 & 79\end{array}$

$\begin{array}{llll}0 & 2 & 0 & 5\end{array}$

$\begin{array}{llll}0 & 4 & 0 & 10\end{array}$

$\begin{array}{llll}0 & 1 & 0 & 3\end{array}$

$\begin{array}{llll}0 & 7 & 0 & 18\end{array}$

$\begin{array}{rrrr}0 & 8 & 0 & 20 \\ 0 . & 1 & 0 & 3 \\ & & & \\ & & & \\ & & & \\ 0 & 5 & 0 & 13 \\ & & & \\ 0 & 2 & 0 & 5 \\ 0 & 5 & 0 & 13 \\ 0 & 2 & 0 & 5 \\ & & & \end{array}$

44. Claystone, bentonitic, brown

43. Claystone, siliceous (almost cherty), dark-yellowish-orange; indurated. Some bentonitic
Upper Miocene-Continued

Santa Margarita Formation--Continued

Upper phosphatic mudstone member-Continued Unit No.

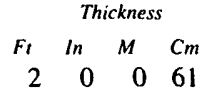

zones in upper half

20

42. Siltstone, pale-orange, friable foraminifers, light-colored, abundant

41. Claystone

40. Bentonite, siliceous; indurated

39. Siltstone, siliceous, phosphatic in upper half. Foraminifers in lower half

$\begin{array}{llll}0 & .6 & 0 & 1.5\end{array}$

$\begin{array}{llll}0 & 4 & 0 & 10\end{array}$

$\begin{array}{llll}0 & 6 & 0 & 15\end{array}$

$\begin{array}{llll}0 & 2 & 0 & 5\end{array}$

38. Claystone, siliceous, bentonitic, and bentonite; grades downward to tuff in lower 11 in. (28 $\mathrm{cm})$. Basal 2 in. $(5 \mathrm{~cm})$, clayey, friable

37. Phosphorite, siliceous, indurated. Upper unit, very phosphatic; middle unit, almost entirely phosphatic pellets, basal unit, moderately phosphatic

$\begin{array}{llll}0 & 7 & 0 & 18\end{array}$

36. Bentonite(?)

35. Phosphorite, pelletal, siliceous; indurated. Unit top and base, slightly phosphatic mudstone

34. Claystone, bentonitic(?), lightgray; slightly siliceous. Mudstone at top. Partings in most of unit

33. Siltstone, siliceous; indurated

32. Phosphorite, pelletal; indurated

31. Claystone, bentonitic

30. Tuff, light-bluish-gray. Thickness uncertain, may be as much as 3 $\mathrm{ft}(91 \mathrm{~cm})$ thick

trace

$\begin{array}{llll}0 & 7 & 0 & 18\end{array}$

$\begin{array}{llll}0 & 10 & 0 & 25\end{array}$

$\begin{array}{llll}0 & 11 & 0 & 28\end{array}$

$\begin{array}{llll}0 & 4 & 0 & 10\end{array}$

$\begin{array}{llll}0 & 5 & 0 & 13\end{array}$

29. Phosphorite, siliceous; indurated. Some nodules or broken phosphatic nodules. Foraminiferal siltstone at top of unit; siliceous siltstone with leached-

- out foraminifers in lower third. Thickness uncertain. Correlation unit $\mathbf{P 2}$

28. Siltstone, siliceous; sheared. Claystone chert intraclasts. Correlation unit $\mathrm{S}$

$\begin{array}{llll}1 & 11 & 0 & 58\end{array}$

27. Sandstone, very fine grained, and sandy siltstone. Some phosphatic pellets. Possible phosphatic mudstone intraclasts, locally at base

12036

26. Siltstone, siliceous, slightly phosphatic; thin-bedded; sheared. Foraminiferal molds, locally abundant

25. Phosphorite, pelletal. Nodules, abundant in zone 4 in. $(10 \mathrm{~cm})$ below top, and abundant in base. Base irregular section repeated, overlying unit correlated across fault.

Unknown thickness

24. Claystone, and siliceous siltstone. Sheared to highly sheared in 
Upper Miocene-Continued

Santa Margarita Formation-Continued

Upper phosphatic mudstone member-Continued Unit No.
Thickness

Ft In $M \quad C m$

lower part; probably not much displacement(?)

$\begin{array}{llll}3 & 10 & 1 & 17\end{array}$

23. Phosphorite, pelletal. Nodules abundant in lower two-thirds of unit. Base, irregular, with clam burrows

22. Claystone, bentonitic, in lower two-thirds of unit, and mudstone, siliceous, indurated, in upper one-third; thin-bedded. Phosphorite, 1 in. $(3 \mathrm{~cm})$ bed 6 in. $(15 \mathrm{~cm})$ above base

21. Phosphorite. Nodules abundant in lower part of unit

20. Siltstone, siliceous; interbedded with bentonitic claystone; thinbedded. Foraminifers, locally abundant

19. Phosphorite, silica-cemented, especially in upper part

18. Siltstone, siliceous; indurated

17. Claystone; upper part is locally. siliceous and moderately indurated; basal part is semifriable

16. Phosphorite, silica cemented indurated

$\begin{array}{llll}0 & 4 & 0 & 10\end{array}$

$\begin{array}{llll}0 & 10 & 0 & 25\end{array}$

$\begin{array}{llll}1 & 4 & 0 & 41\end{array}$

15. Siltstone, siliceous; indurated; foraminiferal molds

14. Claystone, bentonitic

13. Siltstone, siliceous; indurated

12. Phosphorite, silica-cemented at top

$\begin{array}{llll}0 & 2 & 0 & 5\end{array}$

$\begin{array}{llll}0 & 2 & 0 & 5\end{array}$

$\begin{array}{llll}0 & 1 & 0 & 3\end{array}$

$\begin{array}{llll}0 & 3 & 0 & 8\end{array}$

11. Siltstone, clayey; interbedded with some harder siliceous siltstone. Correlation unit S2

10. Claystone, possibly some indurated phosphorite beds; very highly sheared. Lower unit, bentonitic. Thickness approximate

9. Tuff and tuffaceous siltstone

8. Phosphorite, pelletal, siliceous, and porcellanite; indurated. Correlation unit P3

Fault zone: N. $45^{\circ}$ W., left lateral; section missing

7. Siltstone, siliceous, and claystone, slightly phosphatic

Total measured thickness of the upper phosphatic mudstone member: $\begin{array}{llll}0 & 10 & 0 & 25\end{array}$
Upper Miocene:

Santa Margarita Formation:

6. Sandstone, arkosic, white, coarsegrained. Middle unit, indurated. Phosphatic pellets; few, scattered

5. Sandstone, very fine grained. Poorly exposed

4. Siltstone, siliceous; indurated, in part. Poorly exposed

$\begin{array}{llll}10 & 0 & 3 & 5\end{array}$

3. Sandstone, coarse-grained, quartz-rich; indurated

2. Sandstone; contains echinoderms

1. Sandstone; contains oysters

Total measured thickness of the lower sandstone member:
Lower sandstone member:
$6+0183+$

$\begin{array}{llll}50 & 0 & 15 & 24\end{array}$

$\begin{array}{llll}65 & 0 & 19 & 81\end{array}$

$\overline{143}+\overline{0} \overline{43} \overline{5+}$ 
Table 7. Semiquantitative spectrographic analyses of the upper phosphatic mudstone member of the Santa Margarita Formation, at trench 100 in Cuyama Valley phosphate area, Santa Barbara County, Calif.

[ Lower limit of detection of element concentration given with symbol <. Si, $\mathrm{M}$,

$\mathrm{Fe}, \mathrm{Mg}, \mathrm{Ca}, \mathrm{Na}, \mathrm{K}, \mathrm{Ti}, \mathrm{P}, \mathrm{Mn}$, and their oxides given in weight percent; all others

trographic analyses by M. J. Cremer, C. Heropoulos, and L. Meil

\begin{tabular}{|c|c|c|c|c|c|c|}
\hline $\begin{array}{l}\text { Strat. unit } \\
\text { Field No } \\
\text { Sample No }\end{array}$ & $\begin{array}{cc}- & 68 \\
\therefore & 100-1 \\
-- & M-136032\end{array}$ & $\begin{array}{c}67 \\
100-2 \\
M-136033\end{array}$ & $\begin{array}{c}66 \\
100-3 \\
M-136034\end{array}$ & $\begin{array}{c}65 \\
100-4 \\
M-136035\end{array}$ & $\begin{array}{c}64 \\
100-5 \\
M-136036\end{array}$ & $\begin{array}{c}63 \\
100-6 \\
M-136037\end{array}$ \\
\hline \multicolumn{7}{|c|}{ Major elements recalculated as oxides. (percent) } \\
\hline $\begin{array}{ll}\mathrm{SiO}_{2} & \cdots \\
\mathrm{Al}_{2} \mathrm{O}_{3} & \cdots \\
\mathrm{Fe}_{2} \mathrm{O}_{3} & \cdots \\
\mathrm{MgO}_{3} & \cdots \\
\mathrm{C} & \cdots \\
\mathrm{COO} & \cdots\end{array}$ & $\begin{array}{c}>73 \\
6.2 \\
.52 \\
.14 \\
2.0\end{array}$ & $\begin{array}{l}45 \\
8.1 \\
4.4 \\
2.2 \\
2.1\end{array}$ & $\begin{array}{r}41 \\
4.9 \\
1.9 \\
4.3 \\
5.9\end{array}$ & $\begin{array}{c}36 \\
7.9 \\
2.9 \\
2.5 \\
.98\end{array}$ & $\begin{array}{l}54 \\
5.3 \\
2.6 \\
1.3 \\
2.1\end{array}$ & $\begin{array}{c}>73 \\
4.4 \\
1.9 \\
.90 \\
1.7\end{array}$ \\
\hline 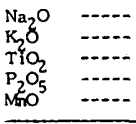 & $\begin{array}{l}2.6 \\
3.1 \\
.11 \\
.39 \\
.0075\end{array}$ & $\begin{array}{l}1.3 \\
2.4 \\
.53 \\
.94 \\
.043\end{array}$ & $\begin{array}{l}1.8 \\
1.6 \\
.20 \\
1.4 \\
.041\end{array}$ & $\begin{array}{l}.67 \\
2.5 \\
.47 \\
.14 \\
.030\end{array}$ & $\begin{array}{l}1.2 \\
2.1 \\
.37 \\
.44 \\
.022\end{array}$ & $\begin{array}{l}1.2 \\
1.5 \\
.23 \\
.34 \\
.016\end{array}$ \\
\hline \multicolumn{7}{|c|}{ Major elements (percent) } \\
\hline $\begin{array}{ll}\text { Si } & - \\
\text { Al } & - \\
\text { Fe } & - \\
\text { Mg } & - \\
\text { Ca } & -\end{array}$ & $\begin{array}{c}>34 \\
3.3 \\
.36 \\
.086 \\
1.4\end{array}$ & $\begin{array}{l}21 \\
4.3 \\
3.1 \\
1.3 \\
1.5\end{array}$ & $\begin{array}{l}19 \\
2.6 \\
1.3 \\
2.6 \\
4.2\end{array}$ & $\begin{array}{c}17 \\
4.2 \\
2.0 \\
1.5 \\
.70\end{array}$ & $\begin{array}{l}25 \\
2.8 \\
1.8 \\
.77 \\
1.5\end{array}$ & $\begin{array}{c}>34 \\
2.3 \\
1.3 \\
.54 \\
1.2\end{array}$ \\
\hline 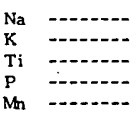 & $\begin{array}{l}1.9 \\
2.5 \\
.066 \\
.17 \\
.0058\end{array}$ & $\begin{array}{l}.95 \\
2.0 \\
.32 \\
.41 \\
.033\end{array}$ & $\begin{array}{l}1.3 \\
1.3 \\
.12 \\
.59 \\
.032\end{array}$ & $\begin{array}{l}.50 \\
2.1 \\
.28 \\
.068 \\
.023\end{array}$ & $\begin{array}{l}.85 \\
1.7 \\
.22 \\
.19 \\
.017\end{array}$ & $\begin{array}{l}.85 \\
1.2 \\
.14 \\
.15 \\
.012\end{array}$ \\
\hline
\end{tabular}

\begin{tabular}{|c|c|c|c|c|c|c|c|}
\hline \multicolumn{2}{|c|}{$\begin{array}{l}\text { Strat. unit } \\
\text { Fi ield No } \\
\text { Sample No }\end{array}$} & \begin{tabular}{cc}
-- & 68 \\
\hdashline- & $100-1$ \\
- & $M-136032$ \\
\end{tabular} & $\begin{array}{r}67 \\
100-2 \\
M-136033 \\
\end{array}$ & $\begin{array}{c}66 \\
100-3 \\
M-136034 \\
\end{array}$ & $\begin{array}{r}65 \\
100-4 \\
M-136035 \\
\end{array}$ & $\begin{array}{c}64 \\
100-5 \\
M-136036\end{array}$ & $\begin{array}{r}63 \\
100-6 \\
M-136037\end{array}$ \\
\hline \multicolumn{8}{|c|}{ Minor elements (ppm) -- cont inued } \\
\hline Th & ------- & $<22$ & $<22$ & $<22$ & $<22$ & $<22$ & $<22$ \\
\hline T1 & --.---- & $<3.2$ & $<3.2$ & $<3.2$ & $<3.2$ & $<3.2$ & $<3.2$ \\
\hline $\operatorname{Tm}$ & -......- & $--\quad<4.6$ & $<4.6$ & $<4.6$ & $<4.6$ & $<4.6$ & $<4.6$ \\
\hline & (-..-- & $\begin{array}{c}-\quad<320 \\
-\quad 4.8\end{array}$ & $\begin{array}{r}<320 \\
70\end{array}$ & $\begin{array}{r}<320 \\
43\end{array}$ & $\begin{array}{r}<320 \\
82\end{array}$ & $\begin{array}{r}<320 \\
71\end{array}$ & $\begin{array}{r}320 \\
37\end{array}$ \\
\hline w & - & $<10$ & $<10$ & $<10$ & $<10$ & $<10$ & $<10$ \\
\hline $\mathrm{Y}$ & ----.-- & 5.2 & 11 & 13 & 3.9 & 13 & 14 \\
\hline Yb & $-\ldots-.--$ & & 1.1 & 1.5 & .63 & 1.8 & 1.2 \\
\hline $\begin{array}{l}z_{n} \\
z_{r}\end{array}$ & (n) & $<10$ & $\begin{array}{l}30 \\
82\end{array}$ & 52 & 22 & 21 & $<10$ \\
\hline \multirow{2}{*}{\multicolumn{2}{|c|}{$\begin{array}{l}\text { Strat. unit } \\
\text { Field No } \\
\text { Sample No }\end{array}$}} & $\begin{array}{c}62 \\
100-7\end{array}$ & $\begin{array}{c}61 \\
100-8\end{array}$ & $\begin{array}{c}60 \\
100-9\end{array}$ & $\begin{array}{c}59 \\
100-10\end{array}$ & $\begin{array}{c}58 \\
100-11\end{array}$ & $\begin{array}{c}57 \\
100-12\end{array}$ \\
\hline & & $---M-136038$ & M-136039 & $\mathrm{M}-136040$ & & $M-136042$ & \\
\hline \multicolumn{8}{|c|}{ Major elements recalculated as oxides (percent) } \\
\hline \multirow{4}{*}{$\begin{array}{l}\mathrm{SiO} \mathrm{Al}_{2} \\
\mathrm{Al}_{2} \mathrm{O}_{3} \\
\mathrm{MgO}_{3} \\
\mathrm{CaO}\end{array}$} & (3)--- & 51 & 51 & 47 & 49 & 49 & 34 \\
\hline & $-\cdots$ & $\begin{array}{l}6.4 \\
2.1\end{array}$ & $\begin{array}{l}5.3 \\
2.0\end{array}$ & $\begin{array}{l}6.8 \\
2.0\end{array}$ & $\begin{array}{l}7.0 \\
2.1\end{array}$ & $\begin{array}{l}6.8 \\
2.0\end{array}$ & $\begin{array}{l}4.5 \\
2.0\end{array}$ \\
\hline & -..- & .78 & 1.2 & .53 & .81 & 1.4 & .60 \\
\hline & -..-- & & 1.8 & 6.3 & 2.9 & 1.5 & 11 \\
\hline \multirow{5}{*}{$\begin{array}{l}\mathrm{Na}_{2} \\
\mathrm{~K}_{2} \\
\mathrm{TiC} \\
\mathrm{P}_{2} \mathrm{C} \\
\mathrm{MnC}\end{array}$} & ---- & 2.2 & 1.2 & 2.2 & 2.2 & 1.3 & 1.8 \\
\hline & ---- & 2.2 & 1.2 & 1.9 & 2.2 & 2.2 & 1.3 \\
\hline & $-\cdots--$ & .25 & .30 & .25 & .37 & .40 & .17 \\
\hline & ---- & 4.8 & .69 & 5.3 & 2.0 & .69 & 8.9 \\
\hline & ---- & .037 & .026 & .068 & .028 & .025 & .052 \\
\hline \multicolumn{8}{|c|}{ Major elements (percent) } \\
\hline \multirow{9}{*}{$\begin{array}{l}\mathrm{Na} \\
\mathrm{K} \\
\mathrm{T} \mathbf{T} \\
\mathrm{P} \\
\mathrm{Mn}\end{array}$} & & 24 & 24 & 22 & 23 & 23 & 16 \\
\hline & --.---- & 3.4 & 2.8 & 3.6 & 3.7 & 3.6 & 2.4 \\
\hline & $\cdots$ & 1.5 & 1.4 & 1.4 & 1.5 & 1.4 & 1.4 \\
\hline & - & .47 & .72 & $\begin{array}{l}.32 \\
4.5\end{array}$ & .49 & .82 &. .36 \\
\hline & & & & & & & \\
\hline & --.-- & 1.6 & .89 & 1.6 & 1.6 & .95 & 1.3 \\
\hline & - & 1.8 & 1.5 & 1.6 & 1.8 & 1.8 & 1.1 \\
\hline & - & 2.13 & .30 & 2.3 & .85 & .30 & \\
\hline & -...--- & .029 & .020 & .053 & .022 & .019 & .040 \\
\hline \multicolumn{8}{|c|}{ Minor elements (ppm) } \\
\hline Ag & - & $-\quad 0.11$ & 0.10 & 0.10 & 0.10 & 0.10 & 0.10 . \\
\hline As & - n....... & $<150$ & $<150$ & & & & \\
\hline Au & 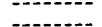 & $=<10$ & $<10$ & $<10$ & $<10$ & & \\
\hline Ba & - & $\begin{array}{l}14 \\
570\end{array}$ & 350 & $\begin{array}{l}16 \\
460\end{array}$ & 480 & $\begin{array}{r}30 \\
450\end{array}$ & 360 \\
\hline Be & $\ldots$ & 1.5 & 1.1 & 2.3 & 1.4 & 1.3 & 2.1 \\
\hline & $\ldots$ & $<15$ & & & & & \\
\hline & -..- & $<32$ & $<32$ & & $<32$ & & $<32$ \\
\hline $\mathrm{Ce}$ & -..---- & 100 & 110 & 120 & 98 & 180 & 110 \\
\hline$C_{0}$ & ------. & 1.6 & 2.0 & 1.5 & 1.3 & 1.4 & 1.3 \\
\hline $\mathrm{Cr}_{\mathbf{r}}$ & -....-. & 36 & 16 & 25 & 19 & 19 & 33 \\
\hline $\mathrm{cu}$ & - & 19 & 24 & & & & \\
\hline Dy & --.---- & $<22$ & $<22$ & $<22$ & $<22$ & $<22$ & $<22$ \\
\hline Er & $-\cdots$ & $<10$ & $<10$ & $<10$ & $<10$ & $<10$ & $<10$ \\
\hline & & & & & & & \\
\hline $\mathrm{Ga}$ & -........ & 5.5 & 6. & & 8.3 & & 5.4 \\
\hline & - & $<15$ & & & & & \\
\hline $\begin{array}{l}\mathrm{Ge} \\
\mathrm{Hf}\end{array}$ & - & $<1.5$ & & & & & \\
\hline $\begin{array}{l}\text { HI } \\
\text { Ho }\end{array}$ & - & $\begin{array}{l}<15 \\
<6.8\end{array}$ & $\begin{array}{l}<15 \\
<6.8\end{array}$ & $<<6.8$ & $<15$ & $\begin{array}{l}<15 \\
<6.8\end{array}$ & $\begin{array}{l}<15 \\
<6.8\end{array}$ \\
\hline In & ...-- & $<6.8$ & $<6.8$ & $<6.8$ & $<6.8$ & $<6,8$ & $<6.8$ \\
\hline I $\mathbf{r}$ & -..---- & $<15$ & & & & & \\
\hline La & -....-- & 55 & & & 48 & & \\
\hline $\mathrm{Li}$ & & $<68$ & $<68$ & & & & $<68$ \\
\hline & & & & & & 26 & \\
\hline & - & 290 & 200 & & & & \\
\hline $\mathrm{No}$ & & $<2.2$ & & $\sum_{<2.2}^{11}$ & $<<2.2$ & $=2.2$ & 8.1 \\
\hline $\mathrm{Nd}$ & -------. & $<46$ & 71 & $<46$ & $<46$ & 77 & 63 \\
\hline & & & & & & & \\
\hline
\end{tabular}


Table 7. Semiquantitative spectrographic analyses of the upper phosphatic mudstone member of the Santa Margarita Formation, at trench 100 in Cuyama Valley phosphate area, Santa Barbara County, Calif.-Continued

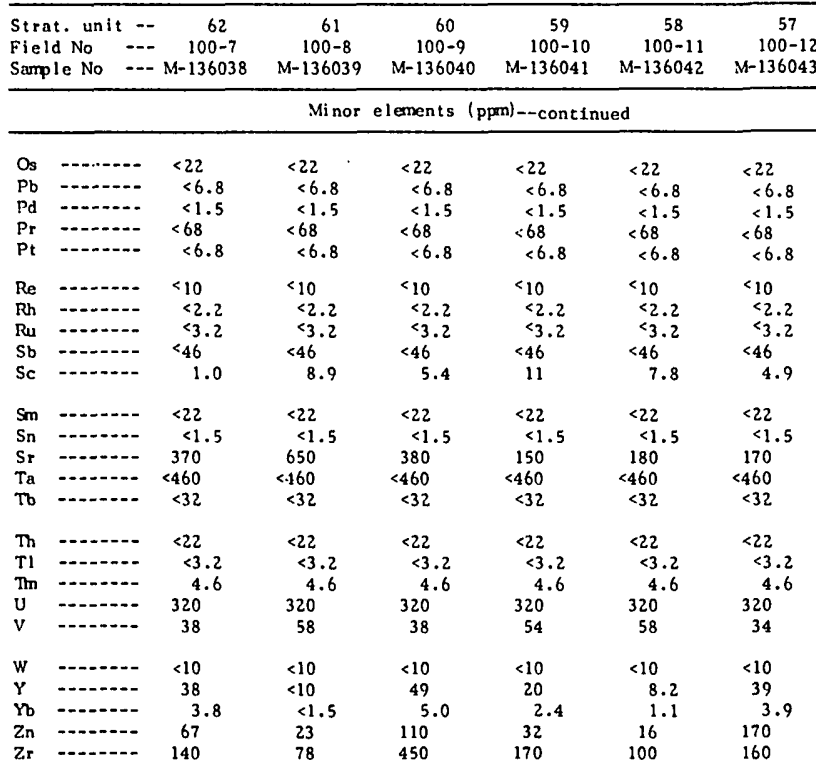

\begin{tabular}{lcccccc}
\hline Strat. unit -- & 56 & 55 & 54 & 53 & 52 & 51 \\
Field No & $100-13$ & $100-14$ & $100-15$ & $100-16$ & $100-17$ & $100-18$
\end{tabular}

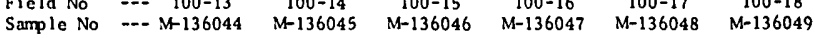
Major elements recalculated as oxides (percent)

\begin{tabular}{|c|c|c|c|c|c|c|c|}
\hline $\begin{array}{l}\mathrm{SiO} \\
\mathrm{Al}_{2} \mathrm{O}_{3} \\
\mathrm{Fe}_{2} \mathrm{O}_{3} \\
\mathrm{Mg}_{3} \\
\mathrm{CaO}\end{array}$ & 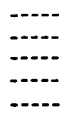 & $\begin{array}{c}26 \\
3.6 \\
1.7 \\
15^{.88}\end{array}$ & $\begin{array}{l}43 \\
5.7 \\
2.4 \\
.96 \\
4.9\end{array}$ & $\begin{array}{c}39 \\
5.1 \\
2.0 \\
1.1 \\
5.0\end{array}$ & $\begin{array}{c}18 \\
3.2 \\
2.1 \\
.88 \\
21\end{array}$ & $\begin{array}{c}54 \\
7.0 \\
3.2 \\
1.6 \\
3.1\end{array}$ & $\begin{array}{l}39 \\
3.2 \\
1.4 \\
.65 \\
6.0\end{array}$ \\
\hline $\begin{array}{l}\mathrm{Na}_{2} \mathrm{O}^{\circ} \\
\mathrm{K}_{2} \mathrm{O} \\
\mathrm{TiO}_{2} \\
\mathrm{P}_{2} \mathrm{O}_{5} \\
\mathrm{MnO}^{2}\end{array}$ & $\begin{array}{c}\cdots \\
\cdots \cdots \\
\cdots \cdots \\
\cdots \\
\cdots\end{array}$ & $\begin{array}{c}1.0 \\
1.0 \\
.17 \\
12.0 \\
.025\end{array}$ & $\begin{array}{c}1.3 \\
1.8 \\
.28 \\
3.7 \\
.022\end{array}$ & $\begin{array}{c}1.3 \\
2.1 \\
.28 \\
3.4 \\
.021\end{array}$ & $\begin{array}{c}1.5 \\
.76 \\
.13 \\
12.0 \\
.090\end{array}$ & $\begin{array}{c}1.3 \\
1.9 \\
.40 \\
1.4 \\
.039\end{array}$ & $\begin{array}{c}1.8 \\
1.5 \\
.11 \\
4.8 \\
.018\end{array}$ \\
\hline
\end{tabular}

\begin{tabular}{|c|c|c|c|c|c|c|c|}
\hline \multicolumn{8}{|c|}{ Major elements (percent) } \\
\hline Si & -......-- & 12 & 20 & 18 & 8.6 & 25 & 18 \\
\hline & -.------ & 1.9 & 3.0 & 2.7 & & 3.7 & 1.7 \\
\hline Fe & -...-.-. & 1.2 & 1.7 & 1.4 & 1.5 & 2.2 & .97 \\
\hline $\begin{array}{l}\mathrm{Mg} \\
\mathrm{Ca}\end{array}$ & - & .53 & .58 & .65 & $15^{.53}$ & .98 & $\begin{array}{r}.39 \\
4.3\end{array}$ \\
\hline $\mathrm{Na}$ & ......... & & & & & .95 & \\
\hline $\begin{array}{l}\text { Na } \\
\mathrm{N}\end{array}$ & - & .85 & 1.5 & 1.7 & .63 & 1.6 & \\
\hline $\mathrm{Ti}$ & ---.--- & .10 & .17 & .17 & .079 & .24 & .064 \\
\hline $\mathrm{P}$ & - & $>4.6$ & 1.6 & $\begin{array}{l}1.5 \\
.016\end{array}$ & $>4.6$ & .63 & 2.1 \\
\hline
\end{tabular}

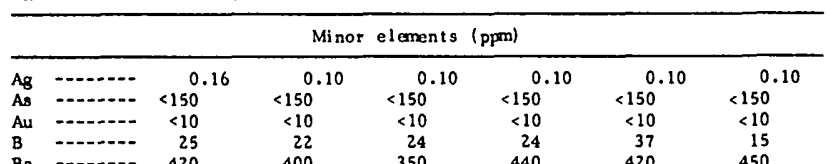

Au $-\cdots---10$

B $-\cdots-125$

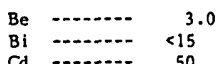

Cd
Ce.......... $\quad \begin{array}{r}50 \\ \text { Co }\end{array}$

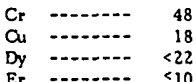

Eu

Ga

Ge

$\begin{array}{lll}\text { Hf } & -\cdots . .- & <15 \\ \text { Ho } & -\cdots .-.- & <6.8\end{array}$

$<2$
22
400

1.8
$<15$
32
99
1.0

1.6
$<15$
32
110
1.0

2.9
$<15$
42
170
1.6

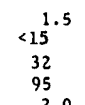

1.1
$<15$
32
110
1.0

29
24
$<22$
$<10$
$<1.5$

$<1.5$

31
23
$<22$
$<10$
$<1.5$

62
15
$<22$
$<10$

$\begin{array}{ccccc}6.1 & 5.3 & 2.9 & 8.4 & 3.7 \\ <15 & <15 & <15 & <15 & <15\end{array}$

$\begin{array}{lllll}<15 & <15 & <15 & <15 & <15 \\ <1.5 & <1.5 & <1.5 & <1.5 & <1.5 \\ <15 & <15 & <15 & <15 & <15\end{array}$

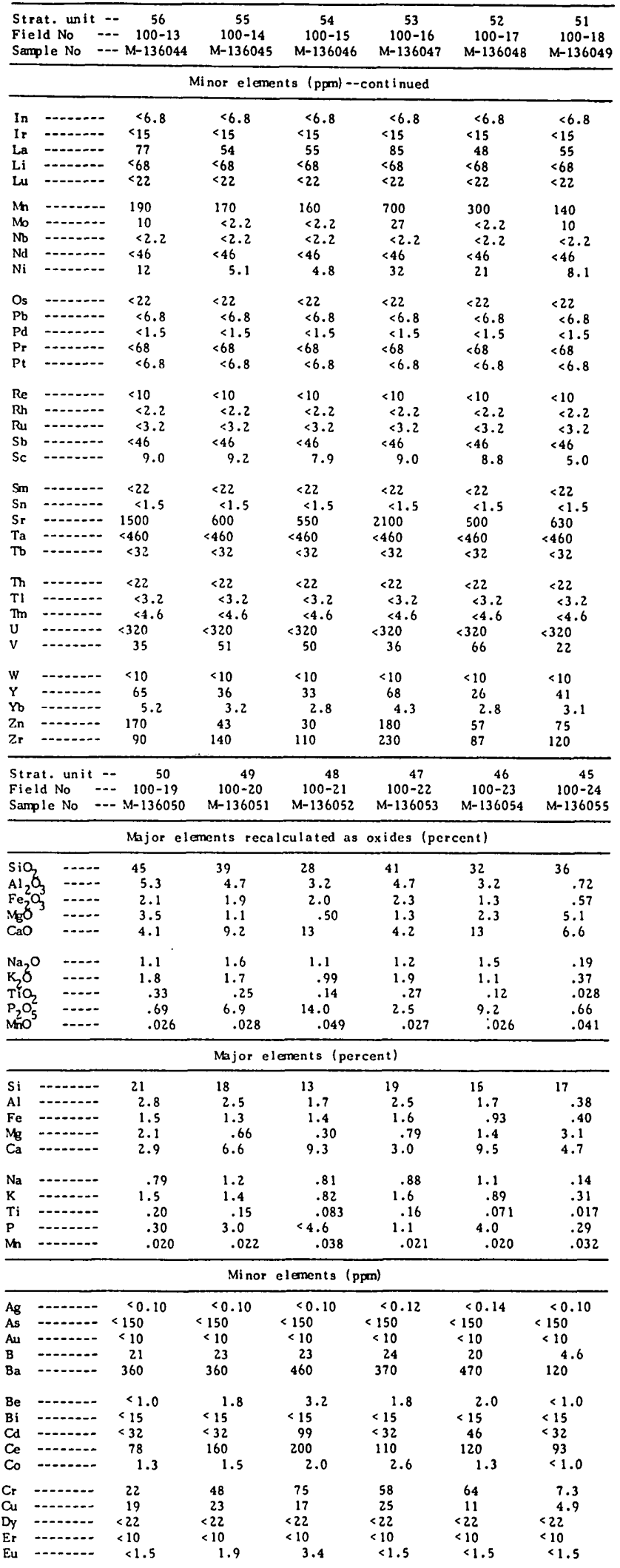


Table 7. Semiquantitative spectrographic analyses of the upper phosphatic mudstone member of the Santa Margarita Formation, at trench 100 in Cuyama Valley phosphate area, Santa Barbara County, Calif.-Continued

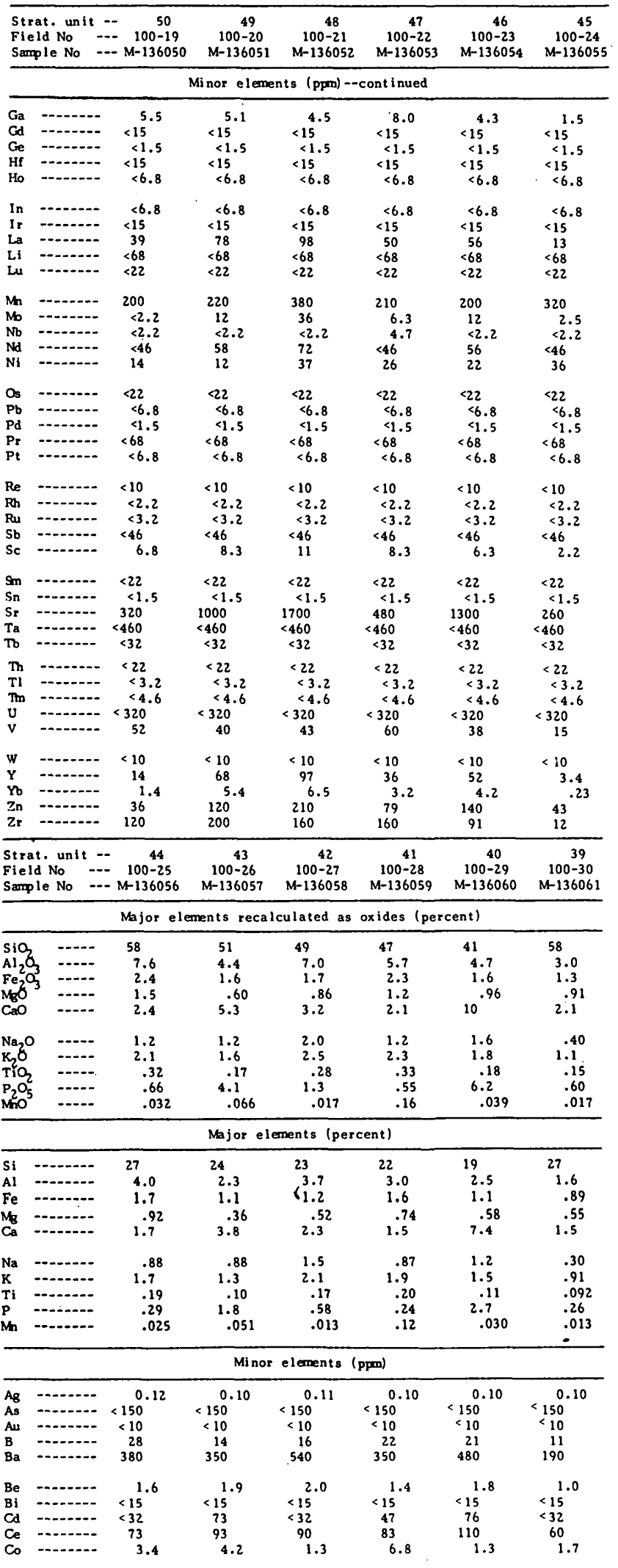

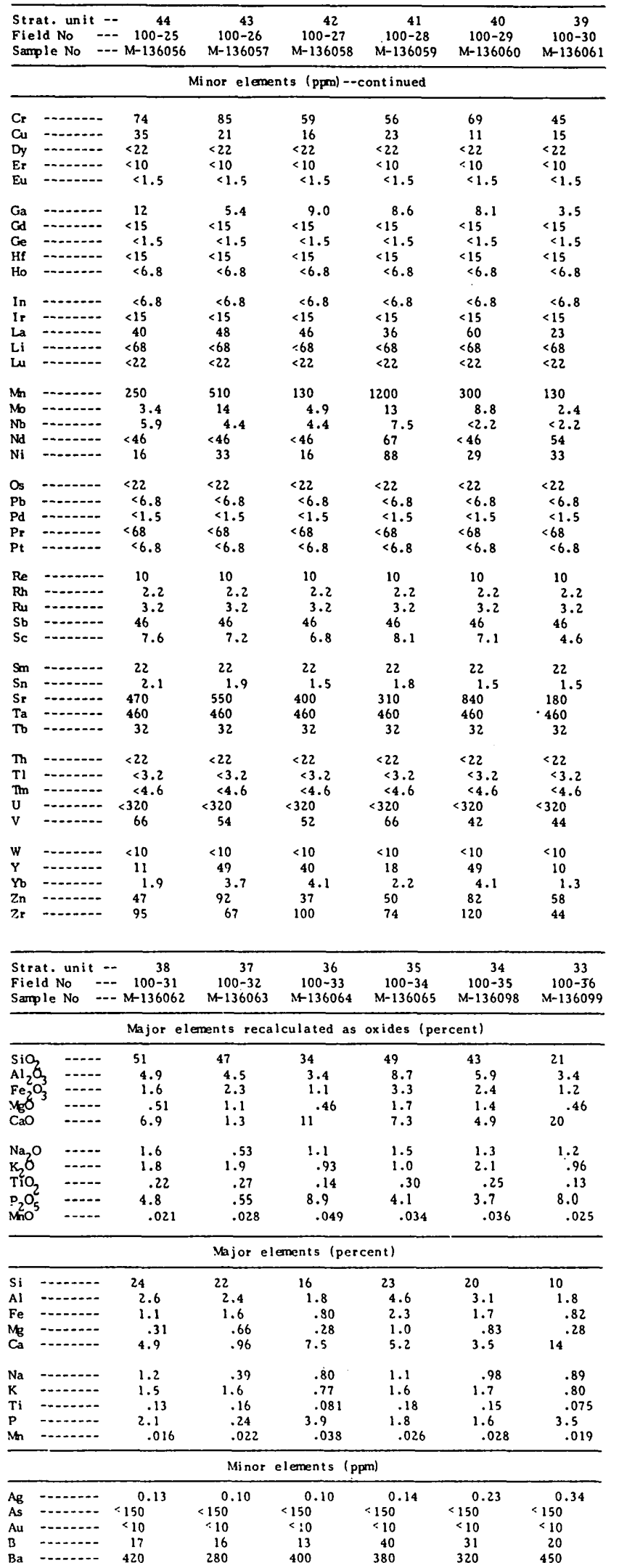


Table 7. Semiquantitative spectrographic analyses of the upper phosphatic mudstone member of the Santa Margarita Formation, at trench 100 in Cuyama Valley phosphate area, Santa Barbara County, Calif.-Continued

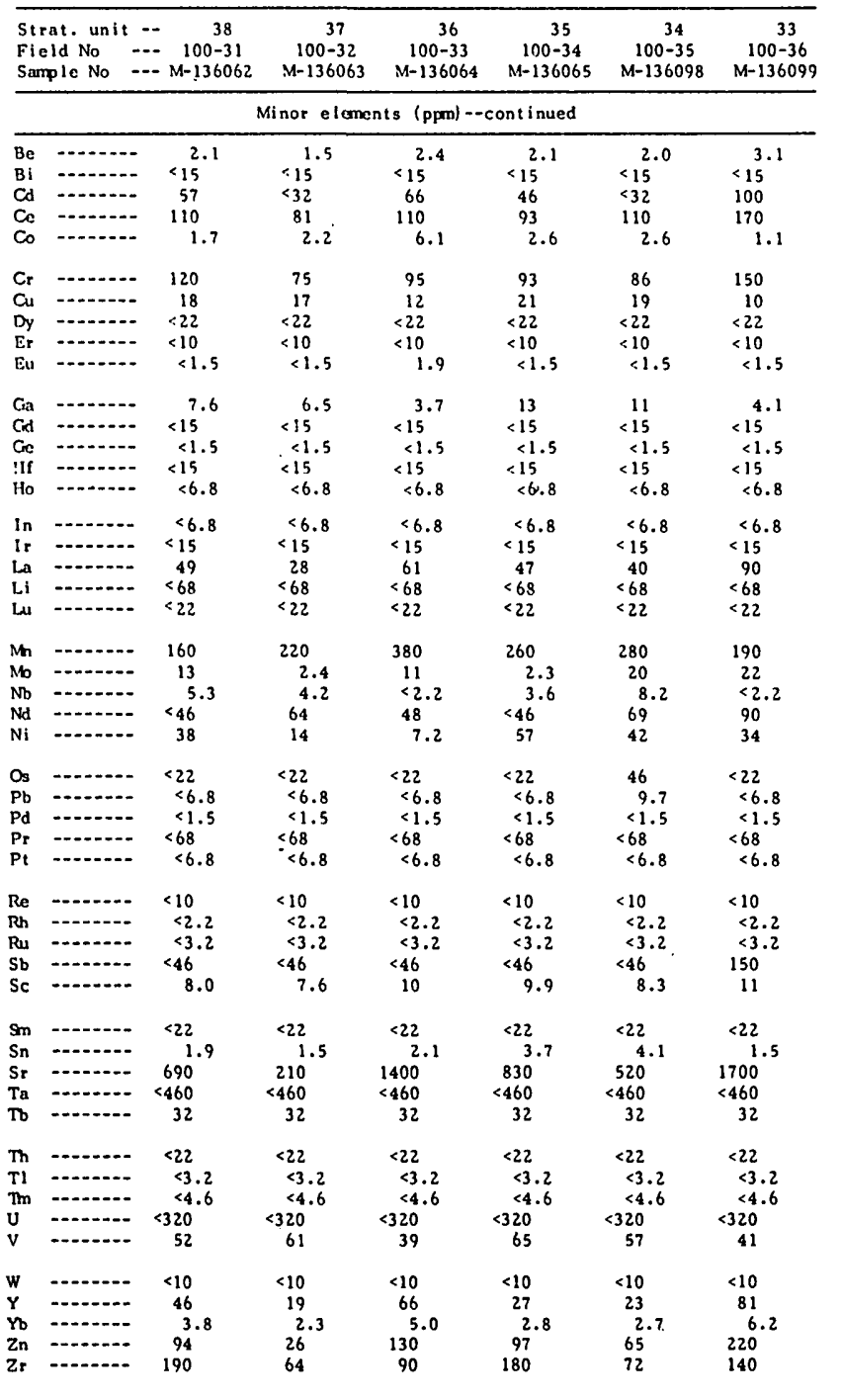

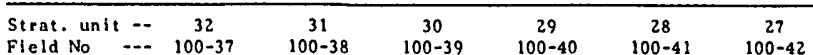

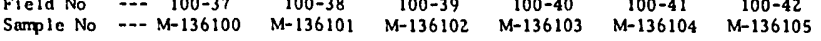
Major elements recalculated as oxides (percent)

\begin{tabular}{|c|c|c|c|c|c|c|c|}
\hline $\begin{array}{l}\mathrm{SiO}_{2} \\
\mathrm{Al}_{2} \mathrm{O}_{3} \\
\mathrm{Fe}_{2} \mathrm{O}_{3} \\
\mathrm{MgO}_{3} \\
\mathrm{CaO}\end{array}$ & \begin{tabular}{c}
$\cdots$ \\
$\cdots$ \\
\hdashline..- \\
\hdashline..- \\
$\cdots$
\end{tabular} & $\begin{array}{l}51 \\
6.8 \\
2.4 \\
1.0 \\
6.7\end{array}$ & $\begin{array}{r}47 \\
4.0 \\
2.3 \\
5.0 \\
1.3\end{array}$ & $\begin{array}{l}49 \\
7.6 \\
1.9 \\
1.0 \\
11\end{array}$ & $\begin{array}{c}51 \\
5.7 \\
2.0 \\
1.2 \\
3.1\end{array}$ & $\begin{array}{l}69 \\
8.1 \\
2.1 \\
.88 \\
5.3\end{array}$ & $\begin{array}{c}>73 \\
2.3 \\
.80 \\
.35 \\
1.7\end{array}$ \\
\hline $\begin{array}{l}\mathrm{Na}_{2} \mathrm{O} \\
\mathrm{K}_{2} \mathrm{O} \\
\mathrm{TiO}_{2} \\
\mathrm{P}_{2} \mathrm{O}_{5} \\
\mathrm{Mmo}^{2}\end{array}$ & 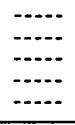 & $\begin{array}{l}1.3 \\
1.9 \\
.25 \\
5.0 \\
.029\end{array}$ & $\begin{array}{c}.49 \\
1.6 \\
.20 \\
.94 \\
.013\end{array}$ & $\begin{array}{c}2.3 \\
2.8 \\
.28 \\
5.7 \\
.053 \\
\end{array}$ & $\begin{array}{l}1.3 \\
2.3 \\
.28 \\
1.6 \\
.018 \\
\end{array}$ & $\begin{array}{l}2.3 \\
2.8 \\
.27 \\
3.0 \\
.023\end{array}$ & $\begin{array}{l}.32 \\
.89 \\
.12 \\
.64 \\
.0062\end{array}$ \\
\hline \multicolumn{8}{|c|}{ Major elements (percent) } \\
\hline $\begin{array}{l}\mathrm{Si} \\
\mathrm{Al} \\
\mathrm{Fe} \\
\mathrm{Mg} \\
\mathrm{Ca}\end{array}$ & ........ & $\begin{array}{c}24 \\
3.6 \\
1.7 \\
.63 \\
4.8\end{array}$ & $\begin{array}{c}22 \\
2.1 \\
1.6 \\
.30 \\
.96\end{array}$ & $\begin{array}{l}23 \\
4.0 \\
1.3 \\
.60 \\
7.5\end{array}$ & $\begin{array}{c}24 \\
3.0 \\
1.4 \\
.73 \\
2.2\end{array}$ & $\begin{array}{c}32 \\
4.3 \\
1.5 \\
.53 \\
3.8\end{array}$ & $\begin{array}{c}94 \\
1.2 \\
.56 \\
.21 \\
1.2\end{array}$ \\
\hline $\begin{array}{ll}N a & - \\
\text { Ka } & - \\
\text { Ti } & - \\
\text { p } & - \\
\text { in } & -\end{array}$ & a... & $\begin{array}{l}.79 \\
1.6 \\
.15 \\
2.2 \\
.018\end{array}$ & $\begin{array}{c}.36 \\
1.3 \\
.12 \\
.41 \\
.010\end{array}$ & $\begin{array}{c}1.7 \\
2.3 \\
.17 \\
2.5 \\
.041\end{array}$ & $\begin{array}{l}.99 \\
1.9 \\
.17 \\
.71 \\
.014\end{array}$ & $\begin{array}{l}1.7 \\
2.3 \\
.16 \\
1.3 \\
.018\end{array}$ & $\begin{array}{l}.24 \\
.74 \\
.074 \\
.28 \\
.0048\end{array}$ \\
\hline
\end{tabular}

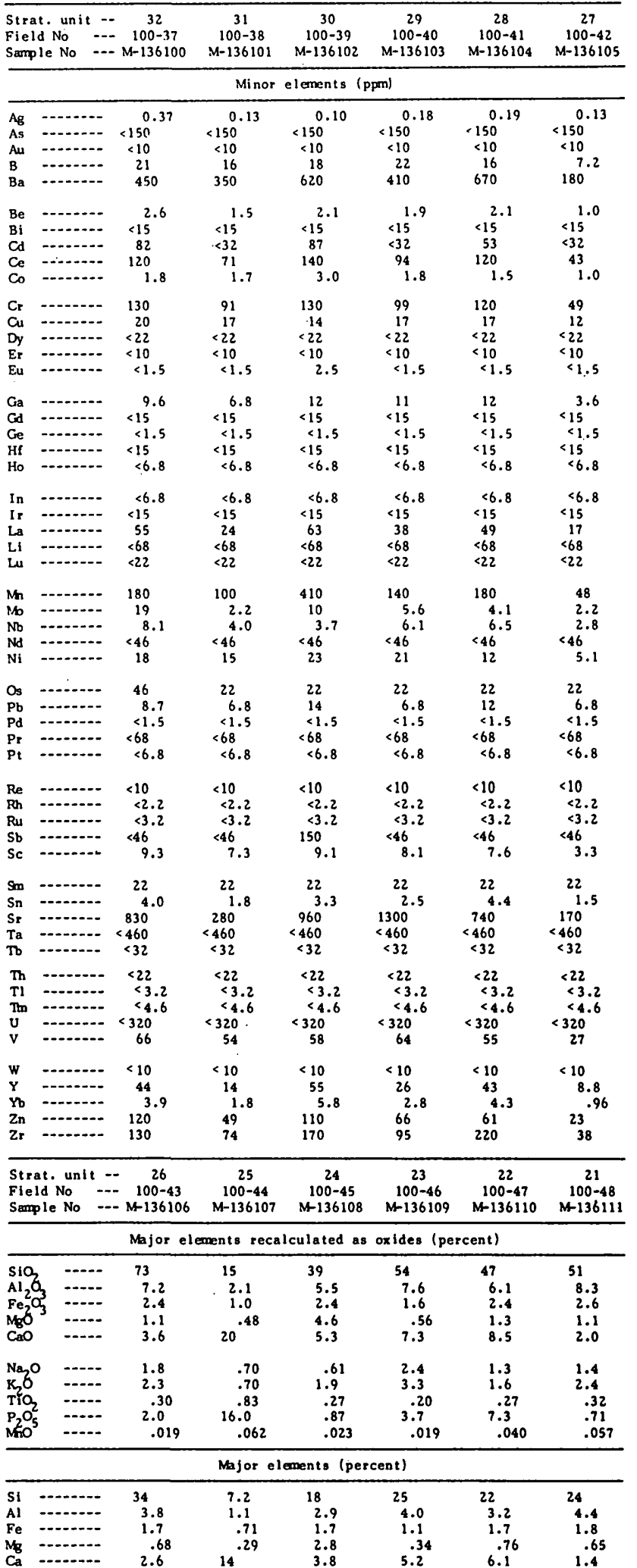


Table 7. Semiquantitative spectrographic analyses of the upper phosphatic mudstone member of the Santa Margarita Formation, at trench 100 in Cuyama Valley phosphate area, Santa Barbara County, Calif.-Continued

\begin{tabular}{|c|c|c|c|c|c|c|c|}
\hline $\begin{array}{l}\text { Stra } \\
\text { Fiel } \\
\text { Samp }\end{array}$ & $\begin{array}{l}\text { at. unit } \\
\text { Id No } \\
\text { ple No }\end{array}$ & {$\left[\begin{array}{c}26 \\
100-43 \\
-M-136106\end{array}\right.$} & $\begin{array}{c}25 \\
100-44 \\
M-136107\end{array}$ & $\begin{array}{c}24 \\
100-45 \\
M-136108\end{array}$ & $\begin{array}{c}23 \\
100-46 \\
M-136109\end{array}$ & $\begin{array}{c}22 \\
100-47 \\
M-136110\end{array}$ & $\begin{array}{c}21 \\
100-48 \\
M-136111\end{array}$ \\
\hline \multicolumn{8}{|c|}{ Major elements (percent)--cont i nuẹd } \\
\hline $\begin{array}{l}\mathrm{Na} \\
\mathrm{K} \\
\mathrm{Ti} \\
\mathrm{P} \\
\mathrm{Mn}\end{array}$ & "י- & $\begin{array}{l}1.3 \\
1.9 \\
.18 \\
.89 \\
.015\end{array}$ & $\begin{array}{c}.52 \\
.58 \\
.05 \\
6.7 \\
.048\end{array}$ & $\begin{array}{l}.45 \\
1.6 \\
.16 \\
.38 \\
.018\end{array}$ & $\begin{array}{l}1.8 \\
2.7 \\
.12 \\
1.6 \\
.015\end{array}$ & $\begin{array}{c}.98 \\
1.3 \\
.16 \\
3.2 \\
.031\end{array}$ & $\begin{array}{l}1.0 \\
2.0 \\
.19 \\
.31 \\
.044\end{array}$ \\
\hline \multicolumn{8}{|c|}{ Minor elements (ppm) } \\
\hline $\begin{array}{l}\mathrm{Ag} \\
\mathrm{As} \\
\mathrm{Aul} \\
\mathrm{B} \\
\mathrm{Ba}\end{array}$ & י & $\begin{array}{c}\quad 0.15 \\
<150 \\
<10 \\
26 \\
450\end{array}$ & $\begin{array}{c}0.12 \\
<150 \\
<10 \\
24 \\
520\end{array}$ & $\begin{array}{c}0.14 \\
<150 \\
<10 \\
32 \\
320\end{array}$ & $\begin{array}{c}0.13 \\
<150 \\
<10 \\
17 \\
720\end{array}$ & $\begin{array}{c}0.17 \\
<150 \\
<10 \\
27 \\
430\end{array}$ & $\begin{aligned} & 0.10 \\
&< 150 \\
&< 10 \\
& 22 \\
& 530\end{aligned}$ \\
\hline $\begin{array}{l}\mathrm{Be} \\
\mathrm{Bi} \\
\mathrm{Cd} \\
\mathrm{Ce} \\
\mathrm{Co}\end{array}$ & - & $\begin{array}{c}1.9 \\
<15 \\
46 \\
100 \\
2.1\end{array}$ & $\begin{array}{l}3.6 \\
<15 \\
180 \\
220 \\
1.4\end{array}$ & $\begin{aligned} & 1.5 \\
< & 15 \\
< & 32 \\
93 & \\
& 2.7\end{aligned}$ & $\begin{array}{l}\quad 2.2 \\
<15 \\
<32 \\
130 \\
\quad 1.3\end{array}$ & $\begin{array}{c}2.5 \\
<15 \\
68 \\
110 \\
2.6\end{array}$ & $\begin{aligned} & 1.8 \\
&< 15 \\
&< 32 \\
& 71 \\
& 4.7\end{aligned}$ \\
\hline $\begin{array}{l}\mathrm{Cr} \\
\mathrm{Cu} \\
\text { Dy } \\
\text { Er } \\
\text { Eu }\end{array}$ & מ & $\begin{array}{r}130 \\
20 . \\
<22 \\
<10 \\
1.5\end{array}$ & $\begin{array}{l}110 \\
\quad 9.4 \\
<22 \\
<10 \\
\quad 3.6\end{array}$ & $\begin{array}{r}80 \\
18 \\
<22 \\
<10 \\
1.5\end{array}$ & $\begin{array}{l}110 \\
7.7 \\
<22 \\
<10 \\
3.2\end{array}$ & $\begin{array}{c}110 \\
13 \\
<22 \\
<10 \\
1.5\end{array}$ & $\begin{array}{r}67 \\
11 \\
<22 \\
<10 \\
1.5\end{array}$ \\
\hline $\begin{array}{l}\text { Ga } \\
\text { Gd } \\
\text { Ge } \\
\text { Hf } \\
\text { Ho }\end{array}$ & 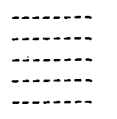 & $\begin{array}{l}12 \\
<15 \\
<1.5 \\
<15 \\
<6.8\end{array}$ & $\begin{aligned} & 2.6 \\
&< 15 \\
&< 1.5 \\
&< 15 \\
&<6.8\end{aligned}$ & $\begin{aligned} & 9.2 \\
< & 15 \\
< & 1.5 \\
< & 15 \\
< & 6.8\end{aligned}$ & $\begin{array}{l}11 \\
<15 \\
<1.5 \\
<15 \\
<6.8\end{array}$ & $\begin{aligned} & 9.6 \\
< & 15 \\
< & 1.5 \\
< & 15 \\
< & <.8\end{aligned}$ & $\begin{array}{l}13 \\
<15 \\
<1.5 \\
<15 \\
<6.8\end{array}$ \\
\hline $\begin{array}{l}\text { In } \\
\text { I } r \\
\text { La } \\
\mathrm{Li} \\
\mathrm{Lu}\end{array}$ & ב. & $\begin{array}{l}<6.8 \\
<15 \\
37 \\
<68 \\
<22\end{array}$ & $\begin{array}{l}\quad 7.1 \\
<15 \\
120 \\
<68 \\
<22\end{array}$ & $\begin{array}{l}<6.8 \\
<15 \\
36 \\
<68 \\
<22\end{array}$ & $\begin{array}{l}<6.8 \\
<15 \\
62 \\
<68 \\
<22\end{array}$ & $\begin{array}{l}<6.8 \\
<15 \\
54 \\
<68 \\
<22\end{array}$ & $\begin{aligned} &< 6.8 \\
&< 15 \\
& 36 \\
&<68 \\
&<22\end{aligned}$ \\
\hline $\begin{array}{l}\mathrm{Mn} \\
\mathrm{Mb} \\
\mathrm{Nb} \\
\mathrm{Nd} \\
\mathrm{Ni}\end{array}$ & 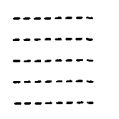 & $\begin{array}{c}150 \\
6.4 \\
7.6 \\
<46 \\
48\end{array}$ & $\begin{array}{c}480 \\
9.9 \\
2.2 \\
<46 \\
42\end{array}$ & $\begin{array}{l}180 \\
2.5 \\
6.6 \\
50 \\
35\end{array}$ & $\begin{array}{c}150 \\
5.1 \\
3.7 \\
56 \\
27\end{array}$ & $\begin{array}{c}310 \\
10 \\
3.6 \\
-46 \\
28\end{array}$ & $\begin{array}{c}440 \\
2.2 \\
9.9 \\
<46 \\
25\end{array}$ \\
\hline $\begin{array}{l}\mathrm{Os} \\
\mathrm{Pb} \\
\mathrm{Pd} \\
\mathrm{Pr} \\
\mathrm{Pt}\end{array}$ & - & $\begin{array}{r}<22 \\
9.2 \\
<1.5 \\
<68 \\
<6.8\end{array}$ & $\begin{array}{r}<22 \\
6.8 \\
<1.5 \\
<68 \\
<6.8\end{array}$ & $\begin{array}{r}<22 \\
6.8 \\
<1.5 \\
<68 \\
<6.8\end{array}$ & $\begin{array}{l}<22 \\
14 \\
<1.5 \\
=68 \\
<6.8\end{array}$ & $\begin{array}{r}<22 \\
\quad 9.0 \\
<1.5 \\
<68 \\
<6.8\end{array}$ & $\begin{array}{r}<2 \\
\quad 2.5 \\
<1.5 \\
<68 \\
<6.8\end{array}$ \\
\hline $\begin{array}{l}\mathrm{Re} \\
\mathrm{Rh} \\
\mathrm{Ru} \\
\mathrm{Sb} \\
\mathrm{Sc}\end{array}$ & (n) & $\begin{aligned} &< 10 \\
&<2.2 \\
&<3.2 \\
&<46 \\
& 7.6\end{aligned}$ & $\begin{array}{l}<10 \\
<2.2 \\
<3.2 \\
150 \\
12\end{array}$ & $\begin{array}{c}<10 \\
<2.2 \\
<3.2 \\
<46 \\
\quad 8.5\end{array}$ & $\begin{array}{c}<10 \\
<2.2 \\
<3.2 \\
<46 \\
5.9\end{array}$ & $\begin{array}{l}<10 \\
<2.2 \\
<3.2 \\
<46 \\
11\end{array}$ & $\begin{array}{c}<10 \\
<2.2 \\
<3.2 \\
<46 \\
7.8\end{array}$ \\
\hline $\begin{array}{l}\text { Sm } \\
\text { Sn } \\
\text { Sr } \\
\mathrm{Ta} \\
\mathrm{Tr}\end{array}$ & ים & $\begin{aligned}<22 \\
3.0 \\
570 \\
<460 \\
<32\end{aligned}$ & $\begin{array}{l}<22 \\
1.5 \\
3000 \\
<460 \\
<32\end{array}$ & $\begin{array}{c}<22 \\
3.9 \\
350 \\
<460 \\
<32\end{array}$ & $\begin{array}{c}<22 \\
3.3 \\
830 \\
<460 \\
<32\end{array}$ & $\begin{array}{c}<22 \\
2.5 \\
940 \\
<460 \\
<32\end{array}$ & $\begin{array}{c}<22 \\
2.6 \\
620 \\
<460 \\
<32\end{array}$ \\
\hline $\begin{array}{l}\mathrm{Th} \\
\mathrm{Tl} \\
\mathrm{Tm} \\
\mathrm{U} \\
\mathrm{V}\end{array}$ & מ & $\begin{array}{l}<22 \\
<3.2 \\
<4.6 \\
320 \\
62\end{array}$ & $\begin{array}{l}<22 \\
<3.2 \\
<4.6 \\
320 \\
41\end{array}$ & $\begin{array}{l}<22 \\
<3.2 \\
<4.6 \\
320 \\
68\end{array}$ & $\begin{array}{l}<22 \\
<3.2 \\
<4.6 \\
320 \\
32\end{array}$ & $\begin{array}{l}<22 \\
<3.2 \\
<4.6 \\
320 \\
60\end{array}$ & $\begin{array}{l}<22 \\
<3.2 \\
<4.6 \\
320 \\
55\end{array}$ \\
\hline $\begin{array}{l}W \\
Y \\
Y b \\
Z n \\
Z r\end{array}$ & ב. & $\begin{array}{c}<10 \\
29 \\
3.1 \\
100 \\
80\end{array}$ & $\begin{array}{l}<10 \\
110 \\
7.2 \\
200 \\
130\end{array}$ & $\begin{array}{c}<10 \\
22 \\
2.5 \\
81 \\
78\end{array}$ & $\begin{array}{c}<10 \\
56 \\
5.2 \\
70 \\
190\end{array}$ & $\begin{array}{c}<10 \\
49 \\
4.0 \\
110^{\circ} \\
160\end{array}$ & $\begin{array}{c}<10 \\
17 \\
2.2 \\
74 \\
130\end{array}$ \\
\hline $\begin{array}{l}\text { Strat } \\
\text { Field } \\
\text { Sampl }\end{array}$ & $\begin{array}{l}\text { at. unit } \\
\text { ld No } \\
\text { ple No } \\
\text {-..- }\end{array}$ & $\begin{array}{c}20 \\
=\quad 100-49 \\
-1-136112\end{array}$ & $\begin{array}{c}19 \\
100-50 \\
M-136113\end{array}$ & $\begin{array}{c}18 \\
100-5 i \\
M-136114\end{array}$ & $\begin{array}{c}17 \\
100-52 \\
M-136115\end{array}$ & $\begin{array}{c}16 \\
100-53 \\
M-136116\end{array}$ & $\begin{array}{c}15 \\
100-54 \\
M-136117\end{array}$ \\
\hline \multicolumn{8}{|c|}{ Major elements recalculated as oxides (percent) } \\
\hline $\begin{array}{l}\mathrm{SiO}_{3} \\
\mathrm{Al}_{2} \mathrm{O}_{3} \\
\mathrm{Fe}_{2} \mathrm{O}_{3} \\
\mathrm{M} \mathrm{O} \\
\mathrm{CaO}\end{array}$ & $\begin{array}{l}g_{3} \\
g_{3} \\
o_{3} \\
\cdots \\
\cdots-\cdots\end{array}$ & $\begin{array}{l}73 \\
7.4 \\
2.9 \\
.98 \\
2.7\end{array}$ & $\begin{array}{l}34 \\
3.0 \\
1.2 \\
. .41\end{array}$ & $\begin{array}{l}43 \\
8.7 \\
2.4 \\
2.3 \\
2.1\end{array}$ & $\begin{array}{l}34 \\
6.2 \\
2.0 \\
2.2 \\
3.9\end{array}$ & $\begin{array}{l}49 \\
5.3 \\
1.6 \\
3.7 \\
6.3\end{array}$ & $\begin{array}{c}39 \\
5.1 \\
.89 \\
12.41\end{array}$ \\
\hline $\begin{array}{l}\mathrm{Na}_{2} \mathrm{O} \\
\mathrm{K}_{2} \mathrm{O} \\
\mathrm{TiO}_{2} \\
\mathrm{P}_{2} \mathrm{O}_{5} \\
\mathrm{M}^{2}\end{array}$ & 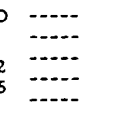 & $\begin{array}{l}1.6 \\
2.5 \\
.38 \\
1.4 \\
.022\end{array}$ & $\begin{array}{l}1.2 \\
1.2 \\
.15 \\
8.5 \\
.044\end{array}$ & $\begin{array}{l}.49 \\
.93 \\
.28 \\
.28 \\
.007\end{array}$ & $\begin{array}{l}.22 \\
.41 \\
.20 \\
.16 \\
.006\end{array}$ & $\begin{array}{l}1.4 \\
1.6 \\
.1 t \\
1.4 \\
.022\end{array}$ & $\begin{array}{l}1.4 \\
1.6 \\
.13 \\
3.2 \\
.11\end{array}$ \\
\hline
\end{tabular}

\begin{tabular}{|c|c|c|c|c|c|c|c|}
\hline \multicolumn{2}{|c|}{$\begin{array}{l}\text { Strat. unit } \\
\text { Field No } \\
\text { Sample No }\end{array}$} & $\begin{array}{l}20 \\
=\quad 100-49 \\
-M-136112\end{array}$ & $\begin{array}{c}19 \\
100-50 \\
M-136113\end{array}$ & $\begin{array}{c}18 \\
100-51 \\
M-136114\end{array}$ & $\begin{array}{c}17 \\
100-52 \\
M-136115\end{array}$ & $\begin{array}{c}16 \\
100-53 \\
M-136116\end{array}$ & $\begin{array}{c}15 \\
100-54 \\
M-136117\end{array}$ \\
\hline \multicolumn{8}{|c|}{ Major elements (percent) } \\
\hline $\mathrm{Si}$ & $-\cdot-$ & $>34$ & 16 & 20 & 16 & 23 & 18 \\
\hline $\mathrm{Al}$ & $-\ldots-$ & 3.9 & 1.6 & 4.6 & 3.3 & 2.8 & 2.7 \\
\hline $\mathrm{Fe}$ & $\cdots$ & 2.0 & .83 & 1.7 & 1.4 & 1.1 & .62 \\
\hline $\mathrm{igg}$ & - n- & .59 & .25 & 1.4 & 1.3 & 2.2 & .25 \\
\hline $\mathrm{Ca}$ & $\cdots$ & 1.9 & 7.6 & 1.5 & 2.8 & 4.5 & 8.4 \\
\hline $\mathrm{Na}$ & $-\cdots-$ & 1.2 & .92 & .36 & .16 & 1.0 & 1.0 \\
\hline $\mathrm{K}$ & 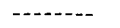 & 2.1 & 1.0 & .77 & .34 & 1.3 & 1.3 \\
\hline $\mathrm{Ti}$ & $-\cdots-$ & .23 & .09 & .17 & .12 & .09 & .08 \\
\hline $\mathrm{P}$ & -..-...- & .61 & 3.7 & .12 & $<.07$ & .59 & 1.4 \\
\hline $\mathrm{Mn}$ & $\cdots+\cdots$ & .017 & .034 & .005 & .004 & .017 & .082 \\
\hline \multicolumn{8}{|c|}{ Minor elements (ppm) } \\
\hline $\mathrm{Ag}$ & -....- & 0.14 & 0.10 & 0.13 & 0.10 & 0.12 & 0.10 \\
\hline As & 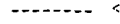 & $<150$ & $<150$ & $<150$ & $<150$ & $<150$ & $<150$ \\
\hline Au & -...--- & $<10$ & $<10$ & $<10$ & $<10$ & $<10$ & $<10$ \\
\hline B & $\cdots$ & 21 & 16 & 25 & 23 & 13 & 9.1 \\
\hline $\mathrm{Ba}$ & - & 540 & 330 & 260 & 150 & 320 & 630 \\
\hline $\mathrm{Be}$ & - & 2.0 & 2.9 & 2.9 & 2.2 & 1.8 & 1.9 \\
\hline $\mathrm{Bi}$ & - & $<15$ & $<15$ & $<15$ & $<15$ & $<15$ & $<15$ \\
\hline $\mathrm{Cd}$ & - & $<32$ & 64 & $<32$ & $<32$ & $<32$ & 65 \\
\hline $\mathrm{Ce}$ & $\cdots$ & 100 & 110 & 170 & 170 & 93 & 86 \\
\hline Co & 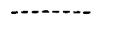 & 2.1 & 3.2 & 1.0 & 1.0 & 1.3 & 1.3 \\
\hline $\mathrm{Cr}_{\mathrm{r}}$ & $\cdots$ & 100 & 100 & 18 & 19 & 52 & 41 \\
\hline $\mathrm{Cu}$ & - & 16 & 11 & 7.9 & 7.4 & 9.3 & 3.0 \\
\hline Dy & - & $<22$ & $<22$ & $<22$ & $<22$ & $<22$ & $<22$ \\
\hline Er & $-\ldots+n$ & $<10$ & $<10$ & $<10$ & $<10$ & $<10$ & $<10$ \\
\hline Eu & - & $<1.5$ & $<1.5$ & 2.4 & $<1.5$ & $<1.5$ & $<1.5$ \\
\hline $\mathrm{Ga}$ & $\cdots$ & 11 & 6.3 & 18 & 15 & 8.8 & 7.9 \\
\hline Gd & - & $<15$ & $<15$ & $<15$ & $<15$ & $<15$ & $<15$ \\
\hline $\mathrm{Ge}$ & - & $<1.5$ & $<1.5$ & $<1.5$ & $<1.5$ & $<1.5$ & $<1.5$ \\
\hline $\mathrm{Hf}$ & ----- & $<15$ & $<15$ & 100 & 100 & $<15$ & $<15$ \\
\hline Ho & -....... & $<6.8$ & $<6.8$ & $<6.8$ & $<6.8$ & $<6.8$ & $<6.8$ \\
\hline In & $\cdots$ & $<6.8$ & $<6.8$ & $<6.8$ & $<6.8$ & $<6.8$ & $<6.8$ \\
\hline I $\mathbf{r}$ & - & $<15$ & $<15$ & $<15$ & $<15$ & $<15$ & $<15$ \\
\hline $\mathrm{La}$ & - & 42 & 49 & 74 & 78 & 28 & 36 \\
\hline $\mathrm{Li}$ & -...- & $<68$ & $<68$ & $<68$ & $<68$ & $<68$ & $<68$ \\
\hline Lu & $--n-1-n$ & $<22$ & $<22$ & $<22$ & $<22$ & $<22$ & $<22$ \\
\hline Mn & $-\cdots$ & 170 & 340 & 52 & 45 & 170 & 820 \\
\hline Mo & ------- & 3.0 & 15 & 2.2 & 2.2 & 3.7 & 2.7 \\
\hline $\mathrm{Nb}$ & - & 11 & 5.2 & 30 & 27 & 6.1 & 2.2 \\
\hline Nd & ------ & $<46$ & $<46$ & $<46$ & $<46$ & $<46$ & $<46$ \\
\hline $\mathrm{Ni}$ & ---- & 17 & 11 & 12 & 15 & 15 & 15 \\
\hline Os & - & $<22$ & $<22$ & $<22$ & $<22$ & $<22$ & $<22$ \\
\hline $\mathrm{Pb}$ & - & 8.6 & 6.8 & 12 & 35 & 6.8 & 8.8 \\
\hline Pd & - & $<1.5$ & $<1.5$ & $<1.5$ & $<1.5$ & $<1.5$ & $<1.5$ \\
\hline $\mathrm{Pr}$ & ---.-... & $<68$ & $<68$ & $<68$ & $<68$ & $<68$ & $<68$ \\
\hline $\mathrm{Pt}$ & $\cdots-\cdots$ & $<6.8$ & $<6.8$ & $<6.8$ & $<6.8$ & $<6.8$ & $<6.8$ \\
\hline $\operatorname{Re}$ & - & $<10$ & $<10$ & $<10$ & $<10$ & $<10$ & $<10$ \\
\hline $\mathrm{Rh}$ & - & $<2.2$ & $<2.2$ & $<2.2$ & $<2.2$ & $<2.2$ & $<2.2$ \\
\hline $\mathrm{Ru}$ & -........ & $<3.2$ & $<3.2$ & $<3.2$ & $<3.2$ & $<3.2$ & $<3.2$ \\
\hline $\mathrm{Sb}$ & - & 150 & 150 & $<46$ & $<46$ & $<46$ & $<46$ \\
\hline Sc & & 9.0 & 6.9 & 7.7 & 6.2 & 5.2 & 6.1 \\
\hline Sm & - & $<22$ & $<22$ & $<22$ & $<22$ & $<22$ & $<22$ \\
\hline Sn & & 2.8 & 2.1 & 7.4 & 6.3 & $<1.5$ & $<1.5$ \\
\hline $\mathrm{Sr}$ & -------- & 500 & 1000 & 230 & 200 & 490 & 790 \\
\hline $\mathrm{Ta}$ & - & $<460$ & $<460$ & $<460$ & $<460$ & $<460$ & $<460$ \\
\hline To & & $<32$ & $<32$ & $<32$ & $<32$ & $<32$ & $<32$ \\
\hline Th & -..... & $<22$ & $<22$. & $<22$ & $<22$ & $<22$ & $<22$ \\
\hline $\mathrm{Tl}$ & -------- & $<3.2$ & $<3.2$ & $<3.2$ & $<3.2$ & $<3.2$ & $<3.2$ \\
\hline In & - & $<4.6$ & $<4.6$ & $<4.6$ & $<4.6$ & $<4.6$ & $<4.6$ \\
\hline $\mathrm{U}$ & & $<320$ & $<320$ & $<320$ & $<320$ & $<320$ & $<320$ \\
\hline $\mathrm{v}$ & & 68 & 44 & 22 & 16 & 36 & 28 \\
\hline w & ----on & $<10$ & $<10$ & $<10$ & $<10$ & $<10$ & $<10$ \\
\hline $\mathrm{Y}$ & - & 32 & 45 & 31 & 21 & 16 & 26 \\
\hline Yb & ------ & 2.7 & 3.1 & 4.2 & 2.7 & 2.2 & 2.1 \\
\hline $\mathrm{Zn}$ & - & 56 & 140 & 43 & 51 & 54 & 91 \\
\hline $\mathbf{Z r}$ & - & 83 & 130 & 620 & 540 & 150 & 160 \\
\hline \multirow{3}{*}{\multicolumn{2}{|c|}{$\begin{array}{l}\text { Strat. unit } \\
\text { Field No } \\
\text { Sample No - }\end{array}$}} & $\begin{array}{l}-\quad 14 \\
\end{array}$ & 13 & & & & \\
\hline & & $-100-55$ & $100-56$ & $100-57$ & $100-58$ & $100-59$ & $100-60$ \\
\hline & & $-M-136118$ & $M-136119$ & $M-136120$ & $M-136121$ & $M-136122$ & $M-136123$ \\
\hline \multicolumn{8}{|c|}{ Major elements recalculated as oxides (percent) } \\
\hline $\mathrm{SiO}$ & --- & $>73$ & $>73$ & $>73$ & $>73$ & $>73$ & 39 \\
\hline $\mathrm{Al}_{2} \mathrm{O}$ & --.- & 13 & 12 & 9.5 & 10 & 13 & 5.5 \\
\hline $\mathrm{Fe}_{2} \mathrm{O}$ & -..-- & 2.1 & 2.6 & 3.2 & 2.6 & 4.0 & 1.3 \\
\hline $\mathrm{MgO}$ & $\cdots$ & .91 & 1.8 & .93 & .86 & 1.4 & 2.3 \\
\hline $\mathrm{CaO}$ & $-\ldots$ & 5.5 & 2.2 & 4.3 & 2.4 & 5.0 & 31 \\
\hline
\end{tabular}


Table 7. Semiquantitative spectrographic analyses of the upper phosphatic mudstone member of the Santa Margarita Formation, at trench 100 in Cuyama Valley phosphate area, Santa Barbara County, Calif._-Continued

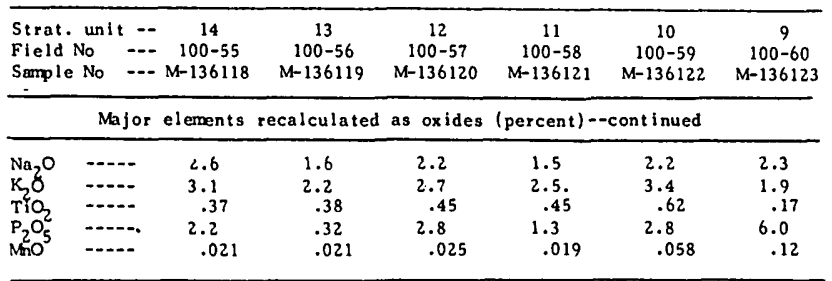

\begin{tabular}{|c|c|c|c|c|c|c|c|}
\hline \multicolumn{8}{|c|}{ Major elements (percent) } \\
\hline $\mathrm{Si}$ & - & $>34$ & $>34$ & $>34$ & $>34$ & $>34$ & $>18$ \\
\hline Al & - & 6.7 & 6.2 & 5.0 & 5.3 & 6.8 & 2.9 \\
\hline $\mathrm{Fe}$ & - & 1.5 & 1.8 & 2.2 & 1.8 & 2.8 & .93 \\
\hline $\mathrm{Mg}$ & - & .55 & 1.1 & .56 & .52 & .85 & 1.4 \\
\hline $\mathrm{Ca}$ & - & 3.9 & 1.6 & 3.1 & 1.7 & 3.6 & 22 \\
\hline $\mathrm{Na}$ & - & 1.9 & 1.2 & 1.6 & 1.1 & 1.6 & 1.7 \\
\hline$\kappa$ & -......- & 2.6 & 1.8 & 2.2 & 2.1 & 2.8 & 1.6 \\
\hline $\mathrm{Ti}$ & --..-- & .22 & .23 & .27 & .27 & .37 & .10 \\
\hline$\ddot{P}$ & $-\ldots$ & .95 & .14 & 1.2 & .56 & 1.2 & 2.6 \\
\hline $\mathrm{Mn}$ & - & .016 & .016 & .019 & .015 & .045 & .093 \\
\hline
\end{tabular}

\begin{tabular}{|c|c|c|c|c|c|c|c|}
\hline \multicolumn{8}{|c|}{ Minor elements (ppm) } \\
\hline $\mathrm{Ag}$ & -.......- & 0.17 & 0.12 & 0.17 & 0.18 & 0.10 & 0.10 \\
\hline As & -......... & $<150$ & $<150$ & $<150$ & $<150$ & $<150$ & $<150$ \\
\hline Au & - & $<10$ & $<10$ & $<10$ & $<10$ & $<10$ & $<10$ \\
\hline B & - n....... & 21 & 29 & 24 & 18 & 27 & 8.1 \\
\hline $\mathrm{Ba}$ & (n......... & 860 & 500 & 560 & 540 & 610 & 710 \\
\hline $\mathrm{Be}$ & -........ & 2.3 & 2.5 & 2.5 & 1.8 & 2.2 & 1.6 \\
\hline$B i$ & .......... & $<15$ & $<15$ & $<15$ & $<15$ & $<15$ & $<15$ \\
\hline $\mathrm{Cd}$ & - & $<32$ & $<32$ & $<32$ & $<32$ & 46 & 99 \\
\hline $\mathrm{Ce}$ & -........ & 93 & 100 & $\cdot 110$ & 86 & 160 & 190 \\
\hline
\end{tabular}

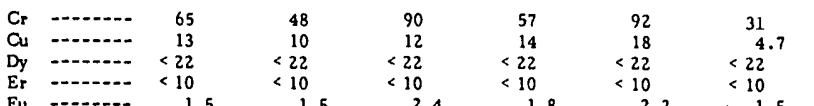

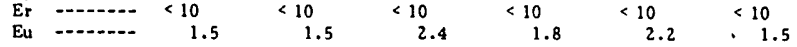

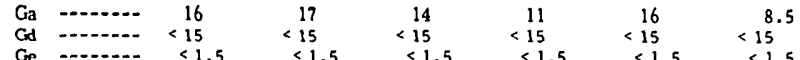

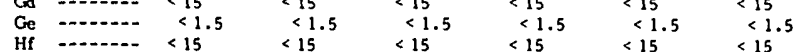

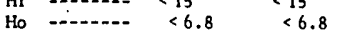

(1)

(1)

Pros

S

S

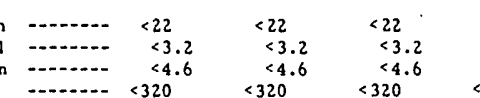

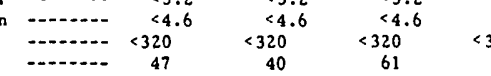

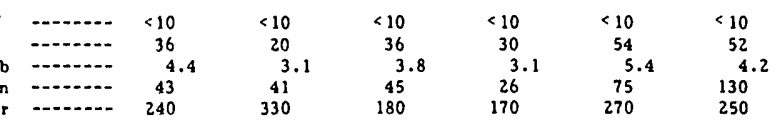

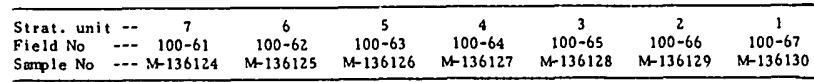
Major elements recalculated as oxides (percent)

\begin{tabular}{|c|c|c|c|c|c|c|c|c|}
\hline $\begin{array}{l}\mathrm{SiO} \mathrm{O} \\
\mathrm{Al}_{2} \mathrm{O}_{3} \\
\mathrm{Fe}_{2} \mathrm{O}_{3} \\
\mathrm{Mb} \\
\mathrm{CaO}\end{array}$ & 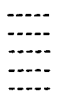 & $\begin{array}{c}>73 \\
9.3 \\
2.6 \\
.95 \\
1.7\end{array}$ & $\begin{array}{c}51 \\
6.6 \\
1.9 \\
3.0 \\
14\end{array}$ & $\begin{array}{r}773 \\
8.1 \\
1.6 \\
5.0 \\
5.5\end{array}$ & $\begin{array}{c}>73 \\
11 \\
3.3 \\
2.3 \\
1.8\end{array}$ & $\begin{array}{l}>73 \\
10 \\
2.1 \\
.85 \\
2.1\end{array}$ & $\begin{array}{l}51 \\
10 \\
2.6 \\
2.8 \\
2.0\end{array}$ & $\begin{array}{c}73 \\
13 \\
1.4 \\
1.5 \\
9.0\end{array}$ \\
\hline $\begin{array}{l}\mathrm{Na}_{2} \mathrm{O} \\
\mathrm{K}_{2} \mathrm{O} \\
\mathrm{TrO}_{2} \\
\mathrm{P}_{2} \mathrm{O}_{5} \\
\mathrm{MnO}^{2}\end{array}$ & 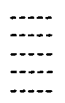 & $\begin{array}{l}1.9 \\
2.5 \\
.37 \\
.66 \\
.019\end{array}$ & $\begin{array}{l}1.8 \\
1.8 \\
.22 \\
8.9 \\
.10\end{array}$ & $\begin{array}{l}2.3 \\
2.1 \\
.28 \\
.78 \\
.048\end{array}$ & $\begin{array}{l}1.5 \\
2.1 \\
.40 \\
.25 \\
.021\end{array}$ & $\begin{array}{c}2.3 \\
2.5 \\
.37 \\
.48 \\
.052\end{array}$ & $\begin{array}{l}1.1 \\
1.6 \\
.40 \\
.30 \\
.013\end{array}$ & $\begin{array}{l}2.6 \\
3.1 \\
.37 \\
.66 \\
.040\end{array}$ \\
\hline \multicolumn{9}{|c|}{ Major elements (percent) } \\
\hline $\begin{array}{ll}\text { Si } & - \\
\text { Al } & - \\
\mathrm{Fe} & -\end{array}$ & a....... & $\begin{array}{r}334 \\
4.6 \\
1.8\end{array}$ & $\begin{array}{c}24 \\
3.5 \\
1.3\end{array}$ & $\begin{array}{r}734 \\
4.3 \\
1.1\end{array}$ & $\begin{array}{r}34 \\
5.8 \\
2.3\end{array}$ & $\begin{array}{r}>34 \\
5.5 \\
1.5\end{array}$ & $\begin{array}{l}24 \\
5.3 \\
1.8\end{array}$ & $\begin{array}{l}>34 \\
7.1 \\
.95\end{array}$ \\
\hline
\end{tabular}

\begin{tabular}{|c|c|c|c|c|c|c|c|c|}
\hline Si & ......... & $>34$ & 24 & $>34$ & $>34$ & $>34$ & 24 & $>34$ \\
\hline A1 & 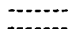 & 4.6 & 3.5 & 4.3 & 5.8 & 5.5 & 5.3 & 7.1 \\
\hline $\mathrm{Fe}$ & 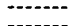 & 1.8 & 1.3 & 1.1 & 2.3 & 1.5 & 1.8 & $\begin{array}{r}.95 \\
.93\end{array}$ \\
\hline MB & 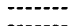 & .57 & 1.8 & 3.0 & 1.4 & .51 & $\begin{array}{l}1.7 \\
1.4\end{array}$ & 6.93 \\
\hline wa & & 1.2 & 10 & 3.9 & 1.3 & 1.5 & & \\
\hline $\mathrm{Na}$ & .......... & 1.4 & 1.3 & 1.7 & 1.1 & 1.7 & .82 & 1.9 \\
\hline$K_{T}^{K}$ & 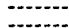 & 2.1 & 1.5 & $\begin{array}{l}1.7 \\
.17\end{array}$ & $\begin{array}{l}1.7 \\
.24\end{array}$ & $\begin{array}{l}2.1 \\
.22\end{array}$ & $\begin{array}{l}1.3 \\
.26\end{array}$ & 2.6 \\
\hline$p$ & 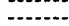 & $\begin{array}{l}.22 \\
.29\end{array}$ & 3.9 & .34 & .11 & $\begin{array}{l}.22 \\
.21\end{array}$ & $\begin{array}{l}.26 \\
.13\end{array}$ & .29 \\
\hline Mn & & .015 & .078 & .037 & .016 & .040 & .010 & .031 \\
\hline
\end{tabular}

\begin{tabular}{|c|c|c|c|c|c|c|c|c|}
\hline \multirow{6}{*}{$\begin{array}{l}\mathrm{Ag}_{\mathrm{g}} \\
\mathrm{As} \\
\mathrm{AA} \\
\mathrm{B} \\
\mathrm{Ba}\end{array}$} & \multicolumn{8}{|c|}{ Minor elements (ppon) } \\
\hline & 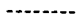 & 0.23 & 0.10 & 0.10 & 0.16 & 0.10 & 0.10 & 0.10 \\
\hline & $\cdots$ & $<150$ & $<150$ & $<150$ & $<150$ & $<150$ & $<150$ & $<150$ \\
\hline & $\cdots$ & $<10$ & $<10$ & $<10$ & $<10$ & $<10$ & $<10$ & $<10$ \\
\hline & 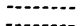 & 10 & 19 & 14 & 22 & 14 & 12 & 10 \\
\hline & -...... & 490 & 420 & 540 & 470 & 590 & 430 & 790 \\
\hline Be & - & 2.3 & 2.5 & 2.0 & 3.2 & 2.3 & 2.0 & 1.6 \\
\hline$B i$ & ......... & $<15$ & $<15$ & $<15$ & $<15$ & & $<15$ & $<15$ \\
\hline Cd & n....... & $<32$ & 46 & $<32$ & $<32$ & $<32$ & $<32$ & 44 \\
\hline $\mathrm{Ce}$ & -......... & & 150 & 93 & 130 & 82 & 89 & 140 \\
\hline Co & - & 1.8 & 2.0 & 1.8 & 2.5 & 2.3 & 1.0 & 1.8 \\
\hline
\end{tabular}

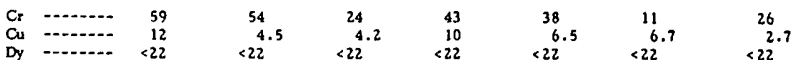

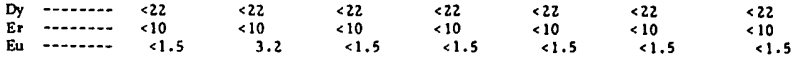

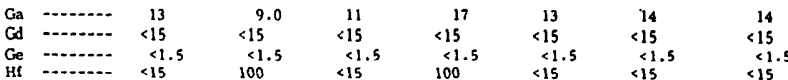

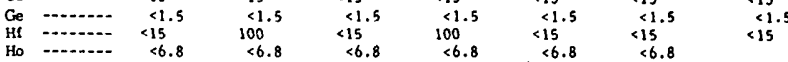

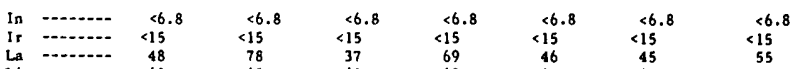

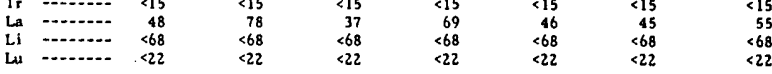

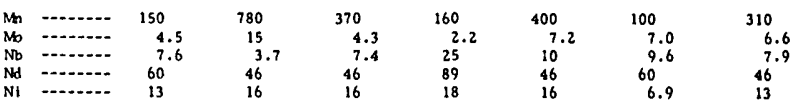

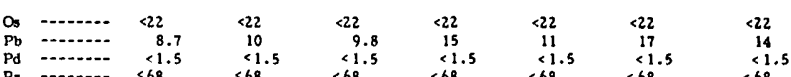

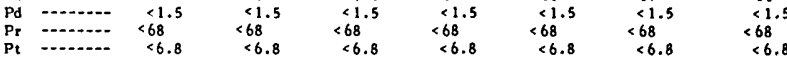

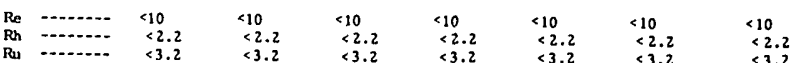

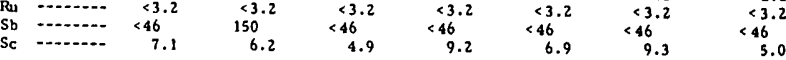

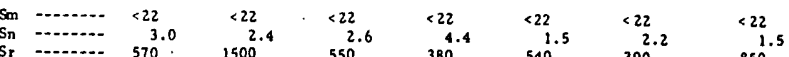

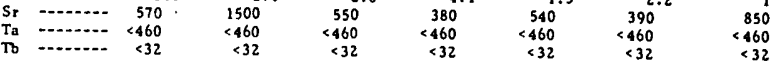

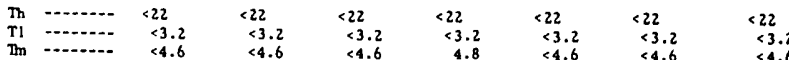

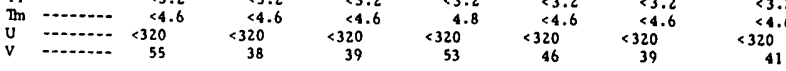

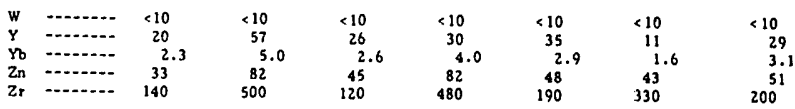


Table 8. Semiquantitative spectrographic analyses of the upper phosphatic mudstone member of the Santa Margarita Formation, at trench 294 in Cuyama Valley phosphate area, Santa Barbara County, Calif.

[Lower limit of detection of element concentration given with symbol <. Si, $\mathrm{Al}, \mathrm{Fe}$, $\mathrm{Mg}, \mathrm{Ca}, \mathrm{Na}, \mathrm{K}, \mathrm{Ti}, \mathrm{P}, \mathrm{Mn}$, and their oxides given in weight percent; all others in parts per million. All element determinations based on semiquantitative spectrographic analyses by M. J. Cremer, C. Heropoulos, and L. Mei]

\begin{tabular}{|c|c|c|c|c|c|c|c|c|c|}
\hline $\begin{array}{l}\text { Strat. unit - } \\
\text { Field No---- } \\
\text { Sample No --- }\end{array}$ & $\begin{array}{c}113 \\
\text { P1-294 } \\
\text { W193356 }\end{array}$ & $\begin{array}{c}88 \\
\text { P2-294 } \\
\text { W193357 }\end{array}$ & $\begin{array}{c}63 \\
\text { P3-294 } \\
\text { W193358 }\end{array}$ & $\begin{array}{c}30 \\
\text { P4-294 } \\
\text { W193359 }\end{array}$ & $\begin{array}{l}\text { Strat. unit - } \\
\text { Field No --- } \\
\text { Sample No --- }\end{array}$ & $\begin{array}{c}113 \\
\mathrm{P} 1-294 \\
\mathrm{~W} 193356\end{array}$ & $\begin{array}{c}88 \\
\text { P2-294 } \\
\text { W193357 }\end{array}$ & $\begin{array}{r}63 \\
\text { P3-294 } \\
\text { W193358 }\end{array}$ & $\begin{array}{r}30 \\
\text { P } 4-294 \\
\text { W193359 }\end{array}$ \\
\hline \multicolumn{5}{|c|}{ Major elements recalculated as oxides (percent) } & \multicolumn{5}{|c|}{ Minor elements (ppm)--continued } \\
\hline $\begin{array}{l}\mathrm{SiO}_{2}- \\
\mathrm{Al}_{2} \mathrm{O}_{3}- \\
\mathrm{Fe}_{2} \mathrm{O}_{3}- \\
\mathrm{MgO}- \\
\mathrm{CaO}-\end{array}$ & $\begin{array}{l}54 \\
9.1 \\
1.6 \\
.63 \\
8.8\end{array}$ & $\begin{array}{l}64 \\
11 \\
1.2 \\
.35 \\
4.8\end{array}$ & $\begin{array}{l}30 \\
4.0 \\
.90 \\
.37 \\
10\end{array}$ & $\begin{array}{l}28 \\
7.8 \\
.89 \\
11.50\end{array}$ & $\begin{array}{l}\mathrm{Ga}-1- \\
\mathrm{Gd}- \\
\mathrm{Ge}- \\
\mathrm{Hf}- \\
\mathrm{Ho}--\end{array}$ & $\begin{array}{c}10 \\
<6.8 \\
<4.6 \\
<100 \\
<6.8\end{array}$ & $\begin{array}{r}9.4 \\
9.5 \\
<4.6 \\
<100 \\
<6.8\end{array}$ & $\begin{array}{c}4.6 \\
12 \\
<4.6 \\
<100 \\
<6.8\end{array}$ & $\begin{aligned} & 5.5 \\
&<6.8 \\
&<4.0 \\
&<100 \\
&<6.8\end{aligned}$ \\
\hline 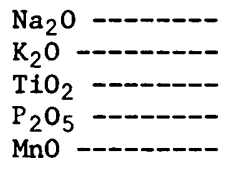 & $\begin{array}{l}1.3 \\
1.3 \\
.23 \\
5.7 \\
.019\end{array}$ & $\begin{array}{l}2.0 \\
1.9 \\
.18 \\
2.5 \\
.017\end{array}$ & $\begin{array}{c}1.0 \\
1.1 \\
.090 \\
.025\end{array}$ & $\begin{array}{l}1.4 \\
1.1 \\
.12 \\
6.0 \\
.053\end{array}$ & 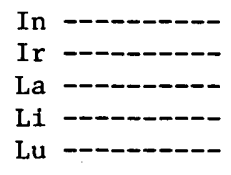 & $\begin{aligned} &<6.8 \\
&< 15 \\
& 48 \\
&< 68 \\
&<22\end{aligned}$ & $\begin{array}{l}<6.8 \\
<15 \\
69 \\
<68 \\
<22\end{array}$ & $\begin{array}{l}<6.8 \\
<15 \\
61 \\
<68 \\
<22\end{array}$ & $\begin{array}{l}<6.8 \\
<15 \\
45 \\
<68 \\
<22\end{array}$ \\
\hline \multicolumn{5}{|c|}{ Major elements (percent) } & Mn - & 150 & $\begin{array}{r}130 \\
25\end{array}$ & $\begin{array}{r}190 \\
32\end{array}$ & 410 \\
\hline 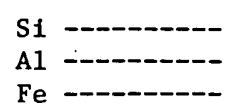 & $\begin{array}{r}25 \\
4.8 \\
1.1\end{array}$ & $\begin{array}{l}30 \\
5.6 \\
.83\end{array}$ & $\begin{array}{l}14 \\
2.1 \\
.63\end{array}$ & $\begin{array}{c}13 \\
4.1 \\
.62\end{array}$ & 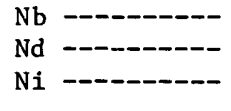 & $\begin{array}{r}10 \\
<46 \\
12\end{array}$ & $\begin{array}{l}<3.2 \\
59 \\
5.4\end{array}$ & $\begin{array}{l}4.5 \\
<46 \\
16\end{array}$ & $\begin{array}{l}<3.2 \\
<46 \\
17\end{array}$ \\
\hline $\mathrm{Mg}=--$ & .38 & $\begin{array}{l}.21 \\
3.4\end{array}$ & $\begin{array}{l}.22 \\
7.3\end{array}$ & $\begin{array}{l}.30 \\
7.7\end{array}$ & $\begin{array}{l}\text { Os }-1-1 \\
\mathrm{~Pb}-\end{array}$ & $\begin{array}{r}<10 \\
12\end{array}$ & $\begin{array}{r}<10 \\
13\end{array}$ & $\begin{array}{r}32 \\
<10\end{array}$ & $\begin{array}{l}<10 \\
<10\end{array}$ \\
\hline $\begin{array}{l}\mathrm{Na}- \\
\mathrm{K}- \\
\mathrm{TI}-\end{array}$ & $\begin{array}{l}.96 \\
1.1 \\
.14\end{array}$ & $\begin{array}{l}1.5 \\
.16 \\
.11\end{array}$ & $\begin{array}{l}.76 \\
.90 \\
.054\end{array}$ & $\begin{array}{l}1.0 \\
.94 \\
.070\end{array}$ & 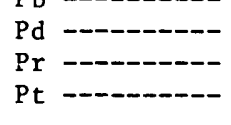 & $\begin{array}{l}<1.5 \\
<68 \\
<6.8\end{array}$ & $\begin{array}{l}<1.5 \\
<68 \\
<6.8\end{array}$ & $\begin{array}{l}<1.5 \\
<68 \\
<6.8\end{array}$ & $\begin{array}{l}<1.5 \\
<68 \\
<6.8\end{array}$ \\
\hline P & 2.5 & 1.1 & 4.9 & 2.6 & Re -------- & $<10$ & $<10$ & $<10$ & $<10$ \\
\hline Mn - - - - - - & .015 & .013 & .019 & .041 & $\mathrm{Rh}-\cdots----$ & $<1.0$ & $<1.0$ & $<1.0$ & $<1.0$ \\
\hline \multicolumn{5}{|c|}{ Minor elements (ppm) } & $\mathrm{Sb}$ & $<100$ & $<100$ & $<100$ & $<100$ \\
\hline 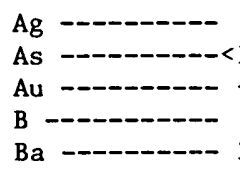 & $\begin{array}{l}0.20 \\
150 \\
<10 \\
40 \\
390\end{array}$ & $\begin{aligned} & 0.13 \\
&< 150 \\
&< 10 \\
& 17 \\
& 500\end{aligned}$ & $\begin{aligned} & 0.32 \\
&< 150 \\
&< 10 \\
& 26 \\
& 450\end{aligned}$ & $\begin{aligned} & 0.10 \\
&< 150 \\
&< 10 \\
& 25 \\
& 420\end{aligned}$ & $\begin{array}{l}\text { Sm }-\cdots \\
\text { Sn }-\cdots \\
\text { Sr }-\cdots \\
\text { Ta }-\cdots\end{array}$ & $\begin{array}{l}<46 \\
<6.8 \\
690 \\
<320 \\
<32\end{array}$ & $\begin{array}{l}<46 \\
<6.8 \\
350 \\
<320 \\
<32\end{array}$ & $\begin{array}{c}<46 \\
<6.8 \\
980 \\
<320 \\
<32\end{array}$ & $\begin{array}{c}<46 \\
<6.8 \\
730 \\
<320 \\
<32\end{array}$ \\
\hline Be -------- & 2.8 & 4.6 & 4.7 & 2.2 & & & & & \\
\hline Bi - & $<22$ & $<22$ & $<22$ & $<22$ & Th - - & $<22$ & $<22$ & $<22$ & $<22$ \\
\hline Cd --------- & $<32$ & $<32$ & 86 & 120 & T1 - - - - - - & $<10$ & $<10$ & $<10$ & $<10$ \\
\hline Ce - - - - & 83 & 130 & 130 & 100 & $\mathrm{Tm}$ & $<4.6$ & $<4.6$ & $<4.6$ & $<4.6$ \\
\hline Co -- & 3.7 & 3.3 & 4.5 & 3.2 & U - - - - & $<320$ & $<320$ & $<320$ & $<320$ \\
\hline $\mathrm{Cr}-\cdots$ & 45 & 58 & 60 & 42 & V - - & 37 & 30 & 33 & 30 \\
\hline $\mathrm{Cu}-------$ & 16 & 13 & 15 & 7.1 & W - - - - - - - & $<10$ & $<10$ & $<10$ & $<10$ \\
\hline Dy -- - - - & $<32$ & $<32$ & $<32$ & $<32$ & Y & 35 & 38 & 67 & 36 \\
\hline Er - - & $<10$ & $<10$ & $<10$ & $<10$ & $\mathrm{Yb}-------$ & 3.4 & 7.3 & 4.5 & 3.0 \\
\hline Eu - - - - - & 2.4 & 3.2 & 2.1 & $<1.5$ & $\begin{array}{l}\mathrm{Zn} \\
\mathrm{Zr}\end{array}$ & $\begin{array}{r}56 \\
310\end{array}$ & $\begin{array}{l}27 \\
82\end{array}$ & $\begin{array}{l}140 \\
300\end{array}$ & $\begin{array}{r}86 \\
270\end{array}$ \\
\hline
\end{tabular}


Table 9. Semiquantitative spectrographic analyses of the upper phosphatic mudstone member of the Santa Margarita Formation, at trench 295 in Cuyama Valley phosphate area, Santa Barbara County, Calif.

[Lower limit of detection of element concentration given with symbol<. $\mathrm{Si}, \mathrm{Al}, \mathrm{Fe}, \mathrm{Mg}, \mathrm{Ca}, \mathrm{Na}, \mathrm{K}, \mathrm{Ti}, \mathrm{P}, \mathrm{Mn}$, and their oxides given in weight percent; all others in parts per million. All element determi-nations based on semiquantitative spectrographic analyses by M. J. Cremer, C. Heropoulos, and L. Mei]

\begin{tabular}{|c|c|c|c|c|c|c|c|c|c|}
\hline $\begin{array}{l}\text { Strat. unit - } \\
\text { Field No -- } \\
\text { Sample No -- }\end{array}$ & $\begin{array}{c}72 \\
\text { P1-295 } \\
\text { W1 } 93360\end{array}$ & $\begin{array}{c}60 \\
\text { P2-295 } \\
\text { W1 } 93361\end{array}$ & $\begin{array}{c}32 \\
\text { P3-295 } \\
\text { W1 } 93362\end{array}$ & $\begin{array}{c}8 \\
\text { P4-295 } \\
\text { W193363 }\end{array}$ & $\begin{array}{l}\text { Strat. unit - } \\
\text { Field No } \\
\text { Sample No. }\end{array}$ & $\begin{array}{c}72 \\
\text { P1-295 } \\
-W 193360\end{array}$ & $\begin{array}{c}60 \\
-2-295 \\
\text { W103361 }\end{array}$ & $\begin{array}{c}32 \\
\text { P3-295 } \\
\text { W1 } 93362\end{array}$ & $\begin{array}{c}8 \\
\text { P4-295 } \\
\text { W1 } 93363\end{array}$ \\
\hline
\end{tabular}

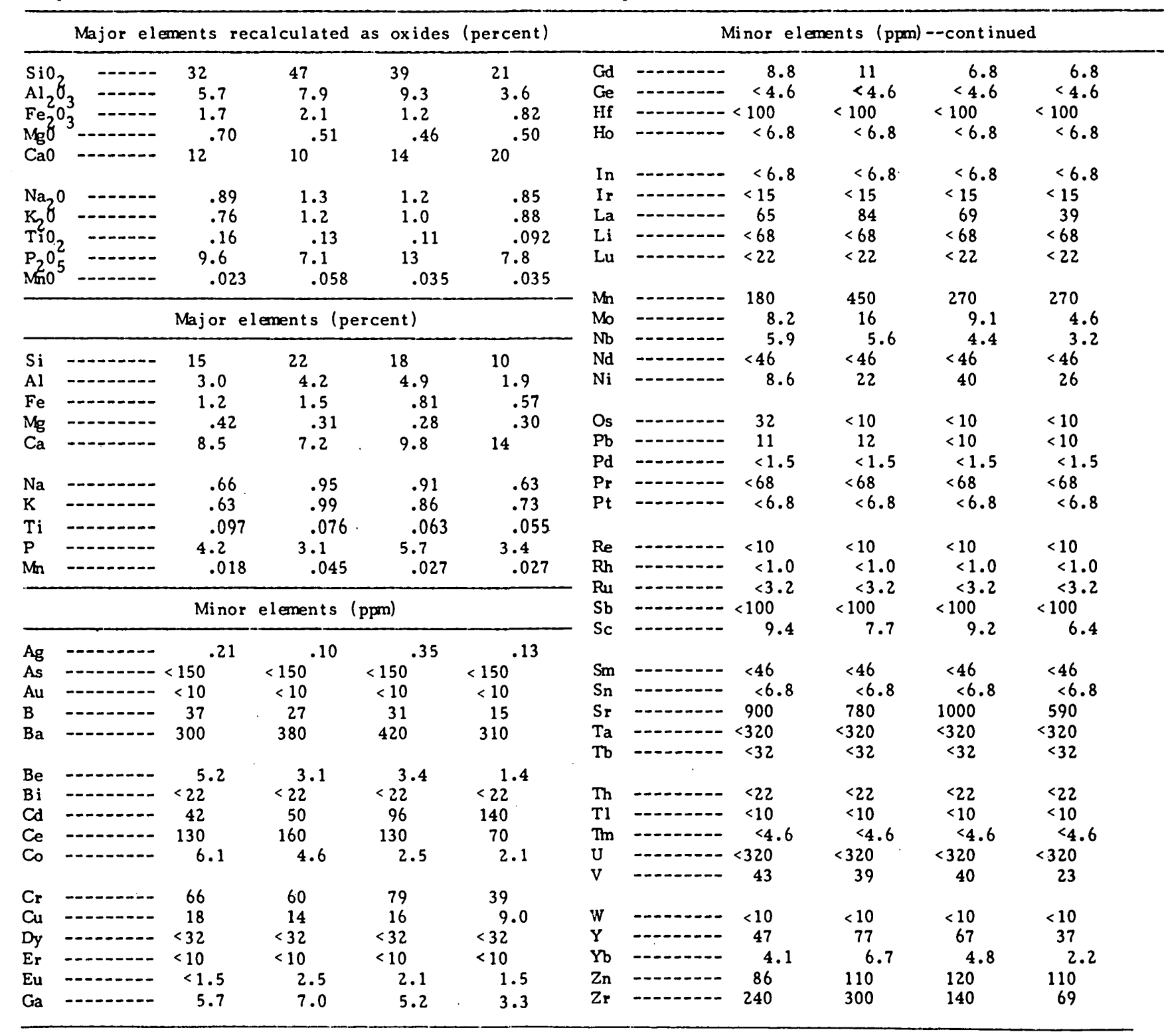


Table 10. Semiquantitative spectrographic analyses of the upper phosphatic mudstone member of the Santa Margarita Formation, at trench 296 in Cuyama Valley phosphate area, Santa Barbara County, Calif.

[Element concentration less than the lower limit of detection is reported as n.d. (not detected). Si, Al, Fe, Mg, Ca, Na, K, Ti, P, Mn given in

weight percent; all others in parts per million. All element

determinations based on semiquantitative spectrographic analyses by M. J.

Cremer, C. Heropoulos, and L. Mei]

\begin{tabular}{|c|c|c|c|c|c|c|c|}
\hline \multicolumn{2}{|c|}{$\begin{array}{l}\text { Strat. unit - } \\
\text { Field No - } \\
\text { Sample No -- }\end{array}$} & $\begin{array}{c}103 \\
C A-1 \\
64 M-1219\end{array}$ & $\begin{array}{c}100 \\
C A-2 \\
64 \mathrm{M}-1220\end{array}$ & $\begin{array}{c}99 \\
\mathrm{CA}-3 \\
64 \mathrm{M}-1221\end{array}$ & $\begin{array}{c}94 \\
\mathrm{CA}-5 \\
64 \mathrm{M}-1222\end{array}$ & $\begin{array}{l}93 \\
\text { CA-6 } \\
64 \mathrm{M}-1223\end{array}$ & $\begin{array}{c}88 \\
C A-7 \\
64 M-1224\end{array}$ \\
\hline \multicolumn{8}{|c|}{ Major elements (percent) } \\
\hline $\mathrm{Si}$ & $-\cdots$ & $>10$ & $>10$ & $>10$ & $>10$ & $>10$ & $>10$ \\
\hline Al & $\cdots$ & 7.0 & 7.0 & 5.0 & 5.0 & 7.0 & 5.0 \\
\hline $\mathrm{Fe}$ & $\ldots$ & 2.0 & 3.0 & 1.5 & 2.0 & 2.0 & 1.0 \\
\hline $\mathrm{Mg}$ & $\cdots$ & .7 & 1.0 & .7 & .7 & 1.0 & 3.0 \\
\hline $\mathrm{Ca}$ & $-\cdots+----$ & 5.0 & 1.0 & 10.0 & 10.0 & 5.0 & 10.0 \\
\hline $\mathrm{Na}$ & -- & 2.0 & 1.5 & 1.5 & 1.5 & 1.5 & 1.5 \\
\hline $\mathrm{K}$ & $-\cdots$ & 2.0 & 2.0 & 1.5 & 1.5 & 2.0 & 1.5 \\
\hline $\mathrm{Ti}$ & $\cdots$ & .3 & .5 & .3 & .3 & .5 & .2 \\
\hline $\mathrm{P}$ & & & n.d. & 3.0 & 7.0 & 0.7 & n.d. \\
\hline Mn & $\cdots$ & .015 & .01 & .05 & .05 & .03 & .02 \\
\hline \multicolumn{8}{|c|}{ Minor elements (ppm) } \\
\hline $\mathrm{Ag}$ & $\cdots$ & n.d. & n.d. & n.d. & n.d. & n.d. & n.d. \\
\hline As & & n.d. & n.d. & n.d. & n.d. & n.d. & n.d. \\
\hline $\mathrm{Au}$ & $-\ldots$ & n.d. & n.d. & n.d. & n.d. & n.d. & n.d. \\
\hline B & $\cdots$ & 20 & 30 & 20 & 15 & 15 & 15 \\
\hline Ba & $\cdots$ & 700 & 500 & 500 & 500 & 500 & 300 \\
\hline $\mathrm{Be}$ & & 1.5 & 1.5 & 2 & 2 & 1 & n.d. \\
\hline $\mathrm{Bi}$ & $\cdots$ & n.d. & n.d. & n.d. & n.d. & n.d. & n.d. \\
\hline $\mathrm{CA}$ & $\cdots$ & n.d. & n.d. & n.d. & n.d. & n.d. & n.d. \\
\hline $\mathrm{Ce}$ & - & n.d. & n.d. & n.d. & n.d. & n.d. & n.d. \\
\hline Co & -- & 3 & 5 & n.d. & 5 & 3 & 7 \\
\hline \multirow{5}{*}{$\begin{array}{l}\mathrm{Cr} \\
\mathrm{Cu} \\
\mathrm{Dy} \\
\mathrm{Er} \\
\mathrm{Eu}\end{array}$} & -- & 100 & 100 & 100 & 150 & 100 & 100 \\
\hline & $\cdots$ & 10 & 20 & .7 & .7 & 10 & 7 \\
\hline & -- & Looked for & only when & $Y$ is found & d above 50 & $\mathrm{ppm}$ & \\
\hline & -....... & Looked for & only when & $Y$ is found & d above 50 & $\mathrm{ppm}$ & \\
\hline & -......... & n.d. & n.d. & n.d. & n.d. & n.d. & n.d. \\
\hline \multirow{5}{*}{$\begin{array}{l}G \\
G \\
G \\
H \\
H\end{array}$} & -- & 10 & 15 & 7 & 7 & 10 & 7 \\
\hline & -- & Looked for & only when & $Y$ is found & d above 50 & $\mathrm{ppm}$ & \\
\hline & $\cdots$ & n.d. & n.d. & n.d. & n.d. & n.d. & n.d. \\
\hline & & n.d. & n.d. & n.d. & n.d.. & n.d. & n.d. \\
\hline & & Looked for & only when & $Y$ is found & d above 50 & $\mathrm{ppm}$ & \\
\hline \multirow{5}{*}{$\begin{array}{l}\text { In } \\
\text { Ir } \\
\text { La } \\
\text { Li } \\
\text { Lu }\end{array}$} & -- & n.d. & n.d. & n.d. & n.d. & n.d. & n.d. \\
\hline & & Looked for & only when & $\mathrm{Pt}$ or $\mathrm{Pd}$ & are found & & \\
\hline & -- & 30 & 30 & 50 & 70 & 30 & n.d. \\
\hline & & n.d. & n.t. & n.d. & n.d. & n.d. & n.d. \\
\hline & $\cdots$ & Looked for & only when & $Y$ is found & id above 50 & pum & \\
\hline \multirow{5}{*}{$\begin{array}{l}\mathrm{Mn} \\
\mathrm{Nb} \\
\mathrm{Nb} \\
\mathrm{Nd} \\
\mathrm{Ni}\end{array}$} & $\ldots . .$. & 150 & 100 & 500 & 500 & 300 & 200 \\
\hline & & 5 & 10 & 3 & 15 & 5 & n.d. \\
\hline & $-\cdots$ & n.d. & 5 & n.d. & n.d. & n.d. & n.d. \\
\hline & & n.d. & n.d. & n.d. & n.d. & n.d. & n.d. \\
\hline & $\cdots$ & 20 & 20 & 50 & 20 & 30 & \\
\hline Os & & Looked for & only when & $\mathrm{Pd}$ or $\mathrm{Pt} f$ & found & & \\
\hline $\mathrm{Pb}$ & -- & 7 & 7 & 7 & 7 & 7 & n.d. \\
\hline Pd & $\ldots$ & n.d. & n.d. & n.d. & n.d. & n.d. & n.d. \\
\hline $\mathrm{Pr}$ & & n.d. & n.d. & n.d. & n.d. & n.d. & n.d. \\
\hline $\mathrm{Pt}$ & & n.d. & n.d. & n.d. & n.d. & n.d. & n.d. \\
\hline \multirow{4}{*}{$\begin{array}{l}\mathrm{Re} \\
\mathrm{Rh} \\
\mathrm{Ru} \\
\mathrm{Sb} \\
\mathrm{So}\end{array}$} & - - & n.d. & n.d. & n.d. & n.d. & n.d. & n.d. \\
\hline & & Looked for & only when & $\mathrm{Pd}$ or $\mathrm{Pt} \mathrm{f}$ & found & & \\
\hline & & Looked for & only when & $\mathrm{Pd}$ or $\mathrm{Pt}$ & found & & \\
\hline & $-\cdots$ & n.d. & n.d. & n.d. & n.d. & n.d. & n.d. \\
\hline Sc & $\cdots$ & 7 & 10 & 10 & 10 & 7 & n.d. \\
\hline \multirow{5}{*}{$\begin{array}{l}\text { Sm } \\
\text { Sn } \\
\text { Sr } \\
\text { Ta } \\
\text { Tr }\end{array}$} & - - & n.d. & n.d. & n.d. & n.d. & n.d. & n.d. \\
\hline & & n.d. & n.d. & n.d. & n.d. & n.d. & n.d. \\
\hline & -......... & 700 & 200 & 700 & 1000 & 500 & 500 \\
\hline & & n.d. & n.d. & n.d. & n.d. & n.d. & n.d. \\
\hline & $\cdots$ & Looked for & only when & $Y$ is found & id above 50 & $\mathrm{ppm}$ & \\
\hline \multirow{5}{*}{$\begin{array}{l}\mathrm{Th} \\
\mathrm{TI} \\
\mathrm{Tn} \\
\mathrm{U} \\
\mathrm{V}\end{array}$} & - n-n & n.d. & n.d. & n.d. & n.d. & n.d. & n.d. \\
\hline & & n.d. & n.d. & n.d. & n.d. & n.d. & n.d. \\
\hline & $\cdots$ & Looked for & only when & $Y$ is found & id above 50 & $\mathrm{ppm}$ & \\
\hline & $\cdots$ & n.d. & n.d. & n.d. & n.d. & n.d. & n.d. \\
\hline & - & Looked for & only when & $Y$ is found & id above 50 & $\mathrm{ppm}$ & \\
\hline & - n-son & n.d. & n.d. & n.d. & n.d. & n.d. & n.d. \\
\hline $\mathrm{Y}$ & 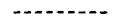 & 30 & 20 & 30 & 50 & 20 & 15 \\
\hline Yo & 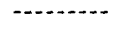 & 3 & 1.5 & 3 & 5 & 1.5 & 1.5 \\
\hline $\mathrm{Zn}$ & - & n.d. & n.d. & n.d. & n.d. & n.d. & n.d. \\
\hline $7 \mathrm{r}$ & & & & & & & \\
\hline
\end{tabular}

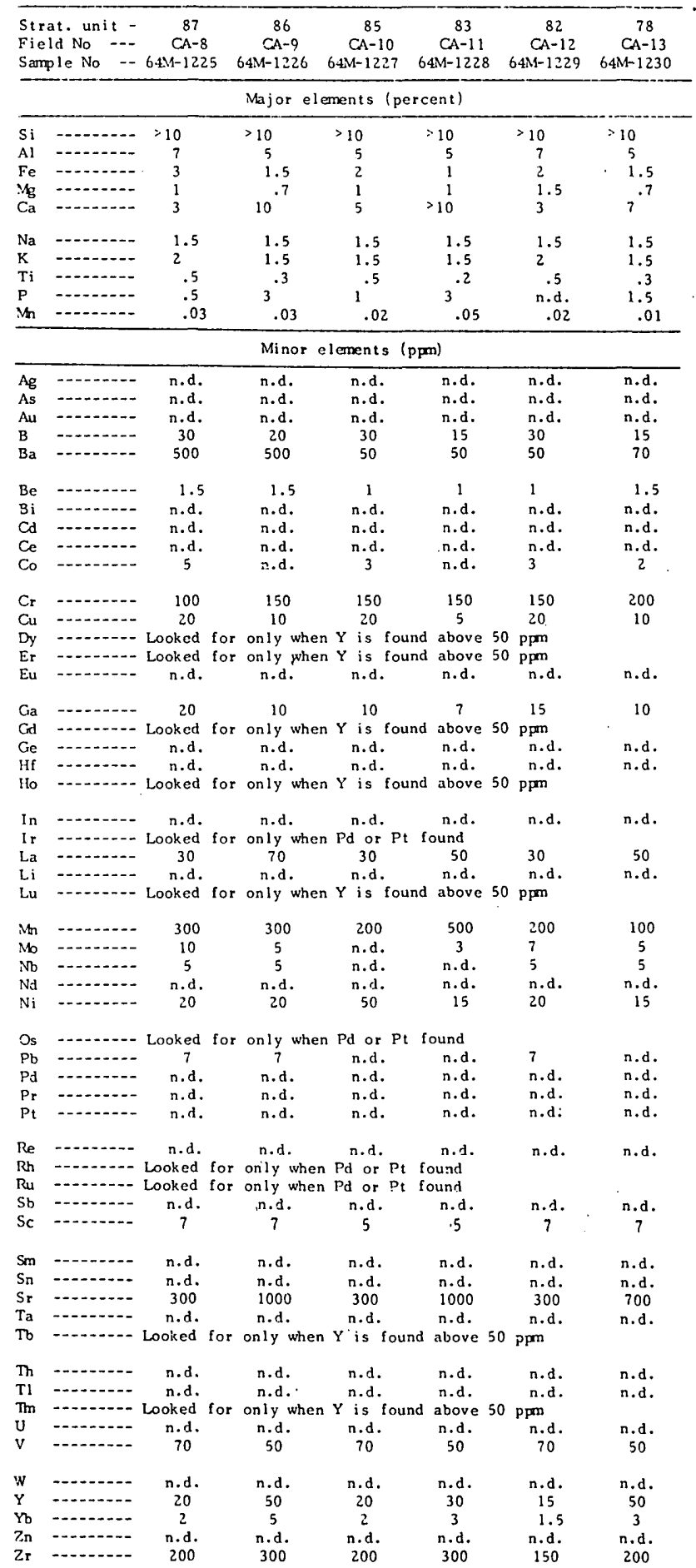


Table 10. Semiquantitative spectrographic analyses of the upper phosphatic mudstone member of the Santa Margarita Formation, at trench 296 in Cuyama Valley phosphate area, Santa Barbara County, Calif._Continued

\begin{tabular}{|c|c|c|c|c|c|c|}
\hline $\begin{array}{l}\text { Strat unit - } \\
\text { Field No -- } \\
\text { Sample No -- }\end{array}$ & $\begin{array}{c}77 \\
C A-14 \\
64 M-1231\end{array}$ & $\begin{array}{c}72 \\
C A-15 \\
64 M-1232\end{array}$ & $\begin{array}{c}71 \\
C A-16 \\
64 M-1233\end{array}$ & $\begin{array}{c}70 \\
C A-17 \\
64 M-1234\end{array}$ & $\begin{array}{c}69 \\
C A-18 \\
64 M-1235\end{array}$ & $\begin{array}{c}68 \\
\text { CA-19 } \\
64 \mathrm{M}-1236\end{array}$ \\
\hline
\end{tabular}

\begin{tabular}{|c|c|c|c|c|c|c|c|}
\hline \multicolumn{8}{|c|}{ Major elements (percent) } \\
\hline $\mathrm{Si}$ & -...-n & $>10$ & $>10$ & $>10$ & $>10$ & $>10$ & $>10$ \\
\hline Al & - & 7 & 7 & 5.0 & 7 & 7 & 7 \\
\hline $\mathrm{Fe}$ & $-\cdots+-$ & 2 & 1.5 & 1.5 & 1 & 2 & 1.5 \\
\hline $\mathrm{Mg}$ & -........ & .5 & .5 & 1.5 & .5 & .7 & 1 \\
\hline $\mathrm{Ca}$ & 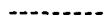 & 2 & $>10$ & 5 & 7 & 7 & 7 \\
\hline $\mathrm{Na}$ & - n-........ & 1.5 & 1.5 & 1.5 & 2 & 1.5 & 1.5 \\
\hline $\mathrm{k}$ & 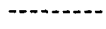 & 1.5 & 1.5 & 1.5 & 1.5 & 1.5 & 1.5 \\
\hline $\mathrm{Ti}$ & 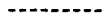 & .3 & .2 & .3 & .3 & .5 & .3 \\
\hline $\mathbf{P}$ & $\cdots-\cdots$ & .7 & 3 & 5 & 2 & n.d. & 1.5 \\
\hline Mn & $-\cdots+--$ & .01 & .03 & .015 & .01 & .01 & .0 \\
\hline
\end{tabular}

Minor elements (ppm)

\begin{tabular}{|c|c|c|c|c|c|c|c|}
\hline $\begin{array}{l}\mathrm{AB} \\
\mathrm{As} \\
\mathrm{Au} \\
\mathrm{B} \\
\mathrm{Ba}\end{array}$ & - & $\begin{array}{l}\text { n.d. } \\
\text { n.d. } \\
\text { n.d. } \\
20 \\
50\end{array}$ & $\begin{array}{l}\text { n.d. } \\
\text { n.d. } \\
\text { n.d. } \\
15 \\
700\end{array}$ & $\begin{array}{l}\text { n.d. } \\
\text { n.d. } \\
\text { n.d. } \\
20 \\
300\end{array}$ & $\begin{array}{l}\text { n.d. } \\
\text { n.d. } \\
\text { n.d. } \\
20 \\
700\end{array}$ & $\begin{array}{l}\text { n.d. } \\
\text { n.d. } \\
\text { n.d. } \\
30 \\
300\end{array}$ & $\begin{array}{l}\text { n.d } \\
\text { n.d } \\
\text { n.d } \\
20 \\
500\end{array}$ \\
\hline $\begin{array}{l}\mathrm{Bc} \\
\mathrm{Bi} \\
\mathrm{Cd} \\
\mathrm{Ce} \\
\mathrm{Co}\end{array}$ & י & $\begin{array}{l}\text { n.d } \\
\text { n.d. } \\
\text { n.d. } \\
\text { n.d. } \\
3\end{array}$ & $\begin{array}{l}1.5 \\
\text { n.d. } \\
\text { n.d. } \\
\text { n.d. } \\
2\end{array}$ & $\begin{array}{l}1 \\
\text { n.d. } \\
\text { n.d. } \\
\text { n.d. } \\
2\end{array}$ & $\begin{array}{l}1.5 \\
\text { n.d. } \\
\text { n.d. } \\
\text { n.d. } \\
\text { n.d. }\end{array}$ & $\begin{array}{l}\text { l } \\
\text { n.d. } \\
\text { n.d. } \\
\text { n.d. } \\
2\end{array}$ & $\begin{array}{l}1 \\
\text { n.d } \\
\text { n.d } \\
\text { n.d } \\
2\end{array}$ \\
\hline $\mathrm{Cr}$ & - & 150 & 150 & 150 & 200 & 150 & 150 \\
\hline
\end{tabular}

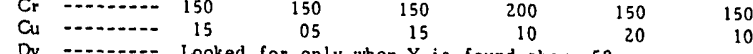

Dy

Eu - Looked for only when $Y$ is found above $50 \mathrm{ppm}$

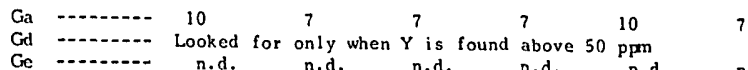

Hf

Ho cooked for only when $Y$ is found above $50 \mathrm{ppm}$

In 1 n.d. n.d. nooked for only when Pd or Pt found n.d. n.d. n.d.

Ir

La

Lu -.... Looked for only when $Y$ is found above 50 ppm n.d. n.d.

$\begin{array}{lllllll}\mathrm{Nd} & \mathrm{Ni} & \mathrm{n} & \mathrm{n} & & & \\ \mathrm{Ni} & \cdots & \text { n.d. } & \text { n.d. } & 5 & 5 & 5 \\ \cdots & 20 & 30 & 30 & 20 & 15 & 30\end{array}$

$\mathrm{Os}$

$\mathrm{Pb}$

Pr

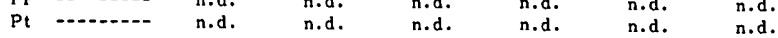

Re

Rh

$\mathrm{Ru}$

Sc

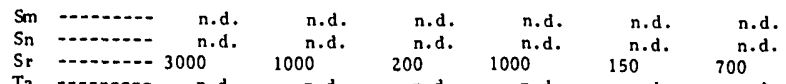

Ta n.d. n.d. $\quad 200$ n.d. n.d. n.d. 700 n.d.

Th ....... n.t. n.d. n.d. n.d. n.d. n.d.

Ti

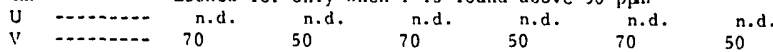

Y

Yb 15

Zn

70
5
$n$.

10
1

50
3
n.d.d.

10
100
n.d.

n.d.
20
2
n.d.
150

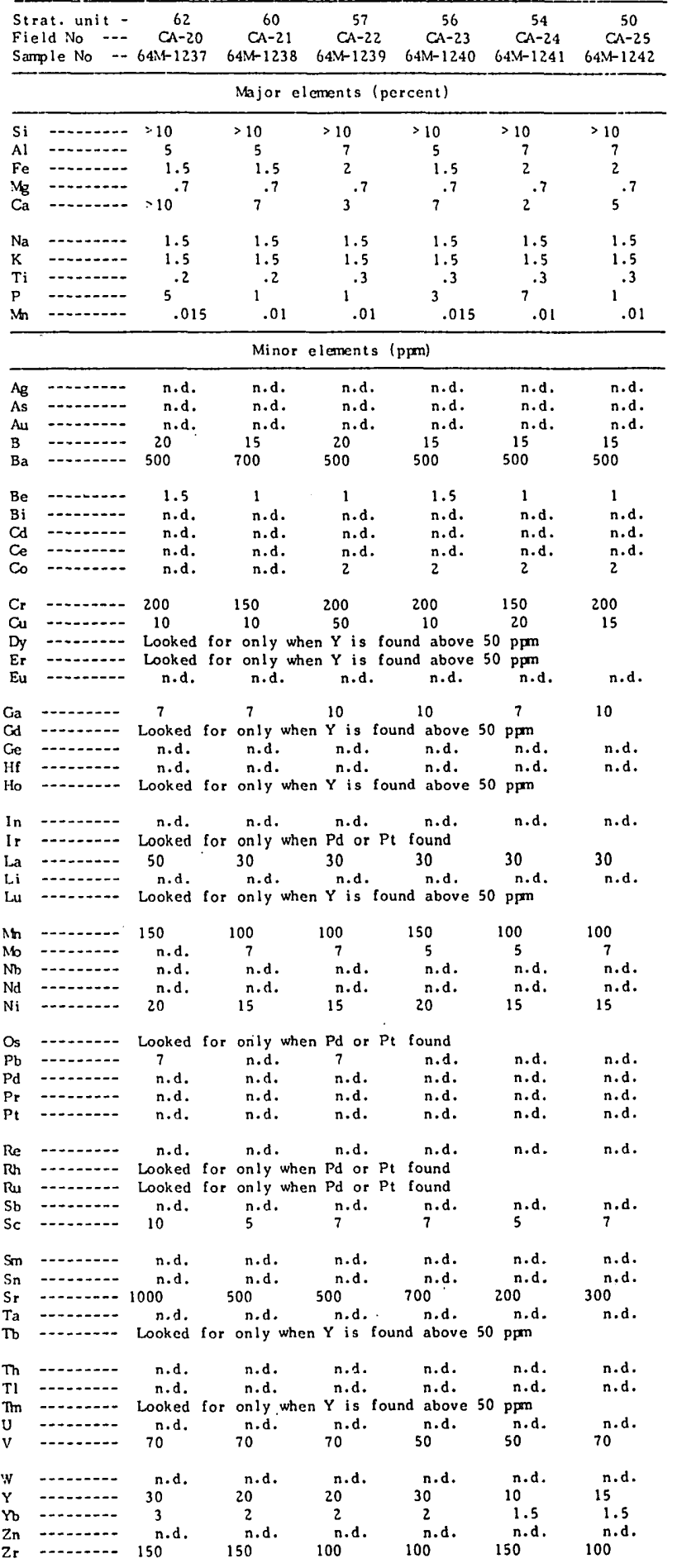


Table 10. Semiquantitative spectrographic analyses of the upper phosphatic mudstone member of the Santa Margarita Formation, at trench 296 in Cuyama Valley phosphate area, Santa Barbara County, Calif.-Continued

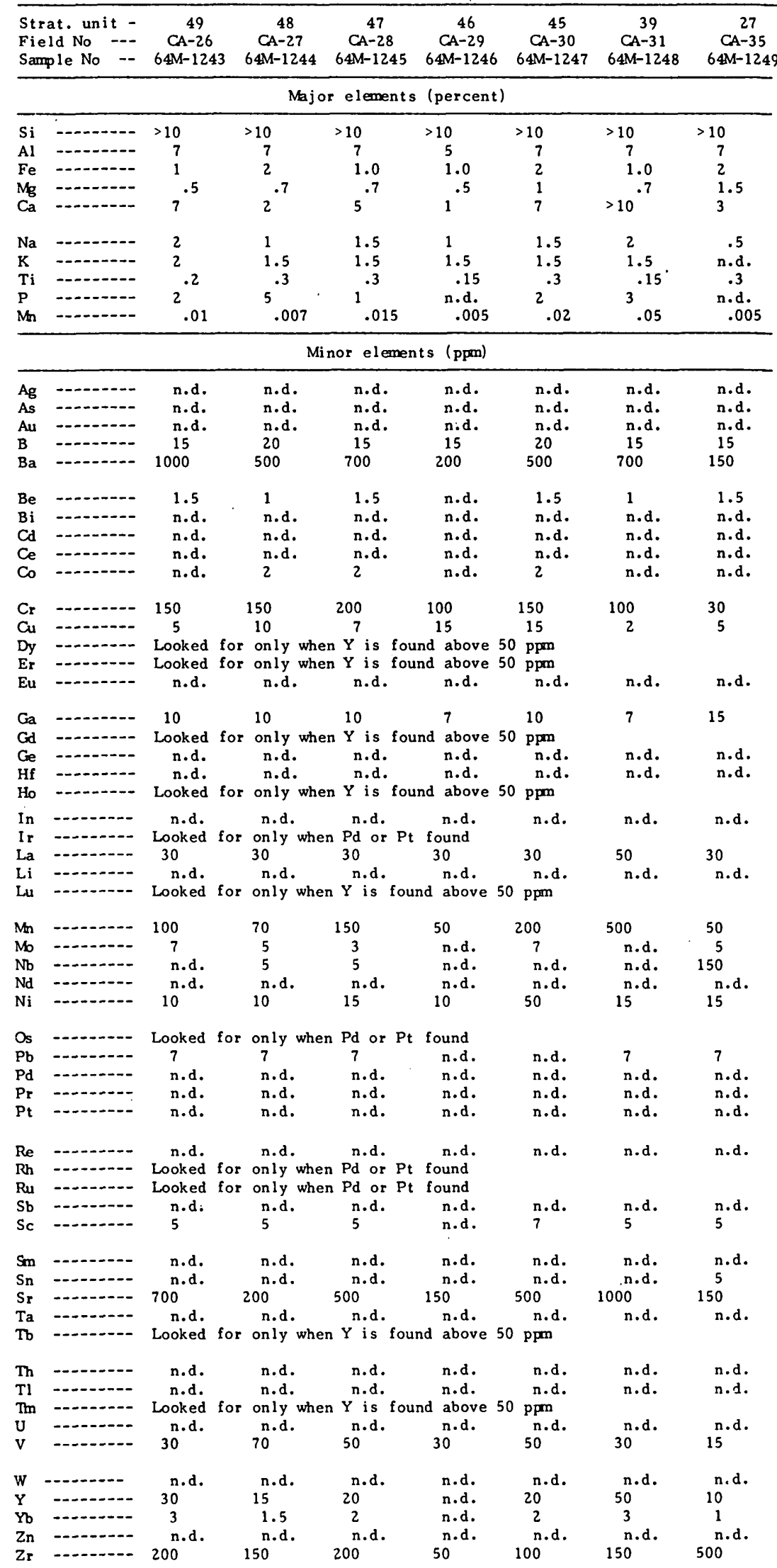


Table 10. Semiquantitative spectrographic analyses of the upper phosphatic mudstone member of the Santa Margarita Formation, at trench 296 in Cuyama Valley phosphate area, Santa Barbara County, Calif.-Continued

[Lower limit of detection of element concentration given with symbol<. $\mathrm{S} 1, \mathrm{Al}, \mathrm{Fe}$, $\mathrm{Mg}, \mathrm{Ca}, \mathrm{Na}, \mathrm{K}, \mathrm{T} f, \mathrm{P}, \mathrm{Mn}$, and their oxides given in weight percent; all others in parts per million. All element determinations based on semiquantitative spectrcoraphic analyses by M. J. Cremer, C. Heropoulos, and L. Mei]

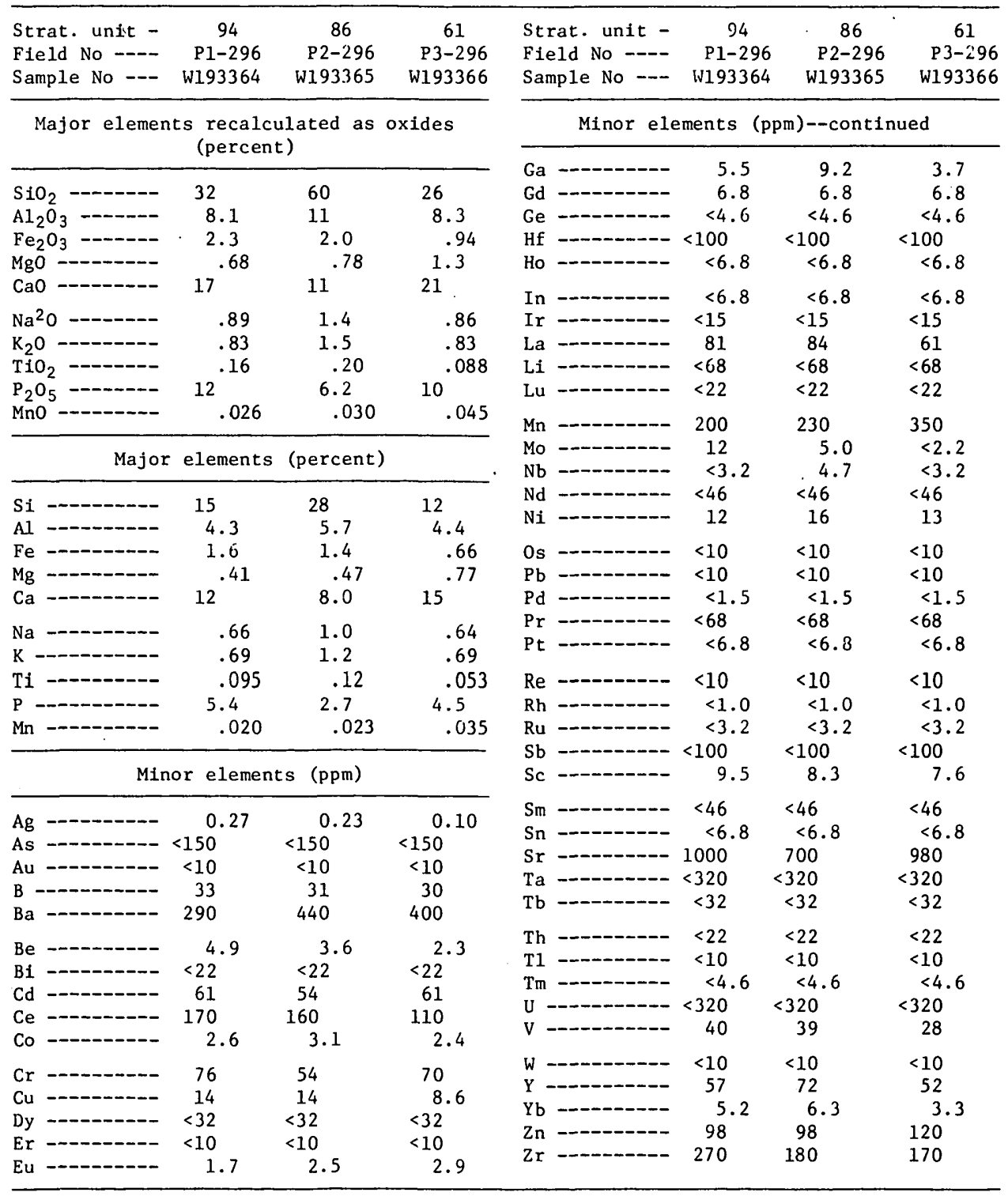


Table 11. Semiquantitative spectrographic analyses of the upper phosphatic mudstone member of the Santa Margarita Formation, at trench 297 in Cuyama Valley phosphate area, Santa Barbara County, Calif.

[Lower limit of detection of element concentration given with symbol<. Si, Al, $\mathrm{Fe}, \mathrm{Mg}, \mathrm{Ca}, \mathrm{Na}, \mathrm{K}, \mathrm{Ti}, \mathrm{P}, \mathrm{Mn}$, and their oxides given in weight percent; all others in parts per million. All element determinations based on semiquantitative spectrographic analyses by $M$. J. Cremer, C. Heropoulos, and L. Mei]

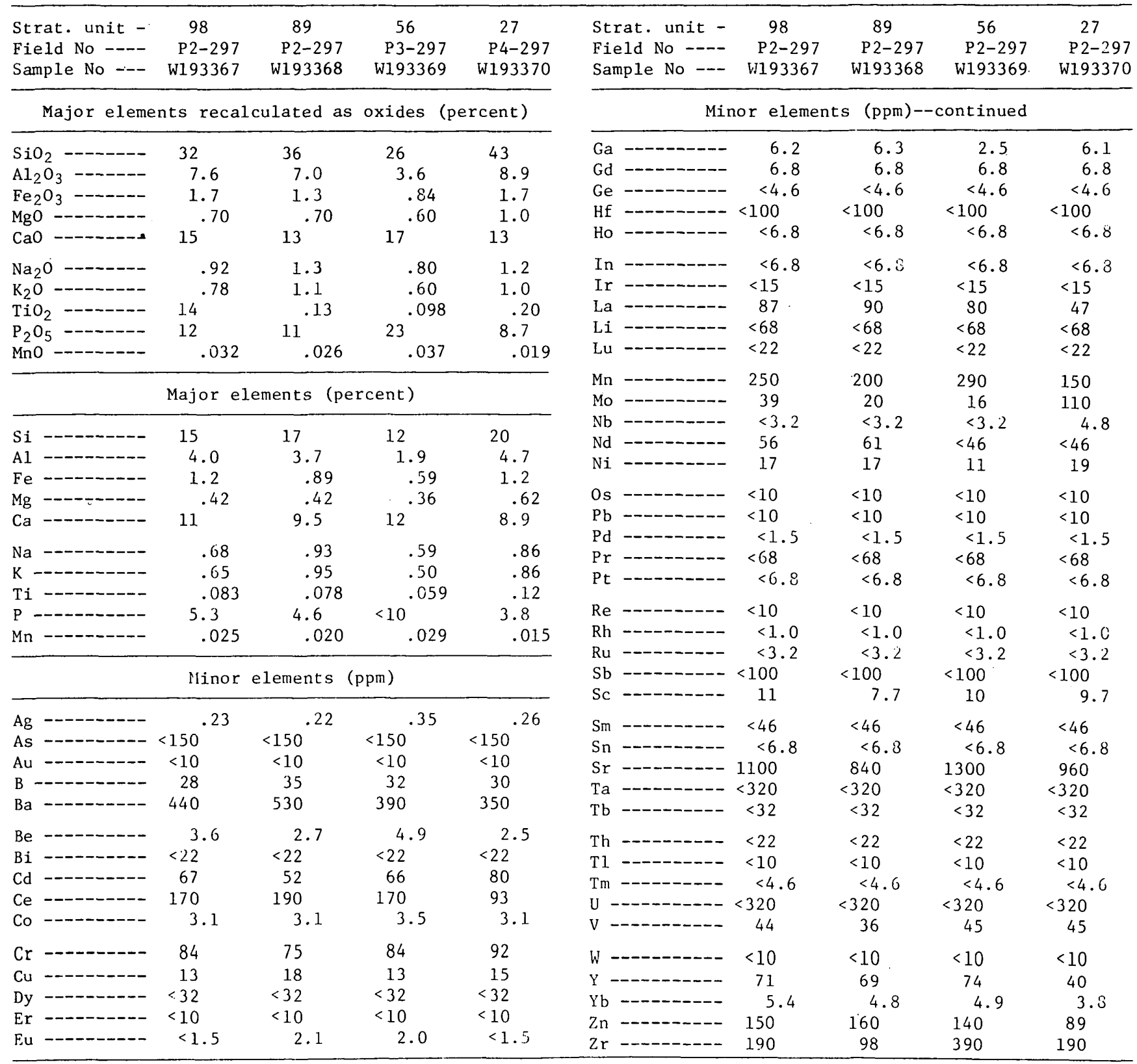


Table 12. Semiquantitative spectrographic analyses of the upper phosphatic mudstone member of the Santa Margarita Formation, at trenches 299 and 300 in Cuyama Valley phosphate area, Santa Barbara County, Calif.

[Element concentration less than the lower limit of detection is reported as $n . d$ (not detected). Si, Al, Fe, $\mathrm{Mg}, \mathrm{Ca}, \mathrm{Na}, \mathrm{K}, \mathrm{Ti}, \mathrm{P}, \mathrm{Mn}$, and their oxides given in weight percent; all others in parts per million. All element determinations based on semiquantitative spectrographic analyses by $M$. J. Cremer, C. Heropoulos, and L. Mei]

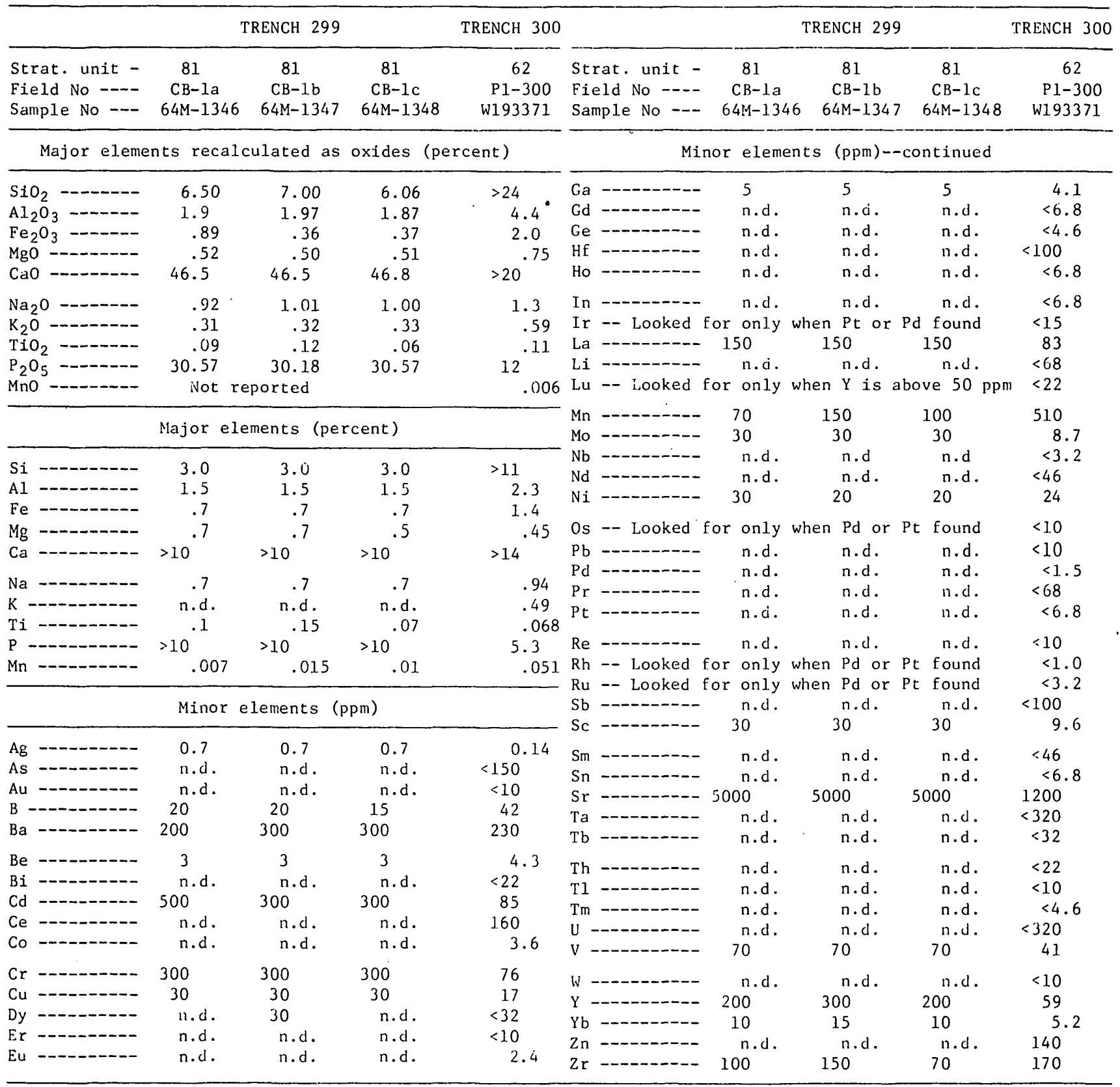


